\title{
STBiO
}

Edgar Blois Crispino

\section{Estudo Morfológico e Caracterização das Espécies de Ceroys Serville, 1838 (Phasmatodea: Heteronemiidae: Heteronemiinae: Pygirhynchini) de Mata Atlântica}

Morphological Assessment and Characterization of Ceroys Serville, 1838 (Phasmatodea:

Heteronemiidae: Heteronemiinae: Pygirhynchini)

Species from the Atlantic Rainforest

v. único

SÃo PAULO 


\section{Estudo Morfológico e Caracterização das Espécies de Ceroys Serville, 1838 (Phasmatodea: Heteronemiidae: Heteronemiinae: Pygirhynchini) de Mata Atlântica}

\section{Morphological Assessment and Characterization of Ceroys Serville, 1838 (Phasmatodea: \\ Heteronemiidae: Heteronemiinae: Pygirhynchini) \\ Species from the Atlantic Rainforest}

$$
\text { v. único }
$$

Versão corrigida

Dissertação submetida ao Programa de Pós-Graduação do Museu de Zoologia da Universidade de São Paulo em cumprimento parcial aos requisitos para a obtenção do título de Mestre em Ciências (Sistemática, Taxonomia Animal e Biodiversidade).

Orientador (a): Profa. Dra. Eliana Marques Cancello 
Autorizo a reprodução e divulgação total ou parcial deste trabalho, por qualquer meio convencional ou eletrônico, para fins de estudo e pesquisa, desde que citada a fonte.

\section{Serviço de Biblioteca e Documentação}

\section{Museu de Zoologia da Universidade de São Paulo}

\section{Catalogação na Publicação}

\section{Crispino, Edgar Blois}

Estudo morfológico e caracterização das espécies de Ceroys Serville, 1838 (Phasmatodea:

Heteronemiidae: Heteronemiinae: Pygirhynchini) de Mata Atlântica. = Morphological assessment and characterization of Ceroys Serville, 1838 (Phasmatodea: Heteronemiidae:

Heteronemiinae: Pygirhynchini) species from the Atlantic rainforest. / Edgar Blois Crispino; orientadora Eliana Marques Cancello. São Paulo, 2021.

$148 \mathrm{p}$.

Dissertação submetida ao Programa de Pós-Graduação do Museu de Zoologia Museu de Zoologia da Universidade de São Paulo, em cumprimento parcial aos requisitos para obtenção do título de Mestre em Ciências (Sistemática, Taxonomia Animal e Biodiversidade).

\section{Versão corrigida}

Volume único

1. Phasmatodea - morfologia. 2. Ceroys Serville, 1838 - Morfologia. 3. Pygirhynchini Mata Atlântica. I. Cancello, Eliana Marques, orient. II. Título.

CDU 595.724 
[CRISPINO, Edgar Blois]

Morphological Assessment and Characterization of Ceroys Serville, 1838 (Phasmatodea: Heteronemiidae: Heteronemiinae: Pygirhynchini) Species from the Atlantic Rainforest

Estudo Morfológico e Caracterização das Espécies de Ceroys Serville, 1838 (Phasmatodea: Heteronemiidae: Heteronemiinae: Pygirhynchini) de Mata Atlântica

Dissertação submetida ao Programa de Pós-Graduação do Museu de Zoologia da Universidade de São Paulo em cumprimento parcial aos requisitos para a obtenção do título de Mestre em Ciências (Sistemática, Taxonomia Animal e Biodiversidade).

Data de aprovação:

\section{COMISSÃO JULGADORA}

Prof. Dr.

Instituição:

Decisão:

Assinatura:

Prof. Dr.

Instituição:

Decisão:

Assinatura:

Prof. Dr.

Instituição:

Decisão:

Assinatura: 


\author{
To see a World in a Grain of Sand \\ And a Heaven in a Wild Flower \\ Hold Infinity in the palm of your hand \\ And Eternity in an hour
}

- William Blake, Auguries of Innocence

Assim agradeço todos os familiares, amigos e colegas que sempre mantiveram meus olhos abertos para os encantos do mundo. 
Aos meus avós, que desde cedo nunca deixaram minha curiosidade morrer. Aos meus pais, que criaram um pequeno biólogo desde berço. Aos meus irmãos, que mesmo seguindo caminhos diferentes me apoiam e me dão forças. A minha companheira, Bianca Rodrigues Stretch Valente pelo apoio e amor constante que mesmo a meio mundo de distância se fazia presente e me deu forças nos momentos mais difíceis.

A Eliana Marques Cancello que não apenas me orientou e me ajudou ao longo de toda a dissertação e reviravoltas no caminho, como também tomou como missão orientar alunos em uma área ainda pouco explorada da ciência brasileira. Ao Prof. José Paulo Gadalluci, Marcoandre Savaris, Pedro Dias e Sérgio Ide pela colaboração, acesso a material histórico e compartilhamento de equipamentos. A Pablo Vallero, que gentilmente compartilhou fotos de dos tipos de Ceroys (Miroceroys) saevissimus. Aos meus colegas, funcionários e professores do Museu de Zoologia da USP, dentre eles Prof. Marcelo Duarte, Prof. Carlos Lamas, Profa. Isabel, Talita, Juan, Maurício, Ana, Dione, Marta, Álvaro, Tamires e tantos outros que muito me ensinaram nas diferentes disciplinas, dinâmicas e conversas pelo museu.

A meus colegas do Projeto Phasma Pedro Ivo Chiquetto Machado, Pedro Álvaro Barbosa de Aguiar Neves, Phillip Watzke Engelking e Victor Morais Ghirotto pelo auxílio, troca de material, comentários, revisões textuais, debates e amizades nesses últimos anos. A Bernardo Ferraz, Júlia de Góis, Ian Meireles, Silvia Harumaki, César Favacho, João Pedro Herculano pelo companheirismo e troca de experiências, Alexandre Bassani pela grande ajuda na edição e tratamento de imagens, e demais colegas que sempre estiveram presentes para me escutar, conversar e descontrair. E a meus alunos, em especial Sofia Honda Carvalho, Laura Freitas e Vinícius, aos quais tento compartilhar o mesmo senso de encanto com o mundo que me foi cultivado. 


\section{RESUMO}

O gênero Ceroys Audinet-Serville 1838 era constituído antes deste trabalho por 15 espécies de ocorrência Neotropical divididas em dois subgêneros, Ceroys (Ceroys) Audinet-Serville 1838 e Ceroys (Miroceroys) Piza 1936. Previamente, a caracterização, distribuição, hábito e morfologia dos sexos da maioria das espécies eram desconhecidos. Através da análise do material tipo e complementar depositado em coleções brasileiras e estrangeiras, apresentamos nessa dissertação a caracterização das dez espécies que ocorrem em território nacional, com a descrição de sexos desconhecidos, ovos, ecologia e distribuição. Análises morfológicas e morfométricas do corpo e ovos foram conduzidas tendo como base a metodologia de trabalhos recentes envolvendo espécies brasileiras. A genitália masculina, bem como a estrutura do ovipositor feminino, também foram analisadas para auxiliar na caracterização das diferentes espécies. O resultado final é a sinonímia de cinco das dez espécies descritas para o Brasil (Ceroys (Ceroys) multispinosum Audinet-Serville, 1838 syn. nov., Ceroys (Ceroys) albogranulatus Piza 1938 syn. nov. e Ceroys (Ceroys) spinosus Zompro, 2004 syn. nov. sob Ceroys (Ceroys) perfoliatus (Gray, 1835); Ceroys (Miroceroys) brunneri Piza, 1936 syn. nov. sob Ceroys (Ceroys) cristatus Redtenbacher, 1906; e Ceroys (Miroceroys) redtenbacheri Piza, 1936 syn. nov. sob Ceroys (Miroceroys) saevissimus Westwood, 1859) a transferência de uma espécie para o gênero Canuleius Stål, 1875 (Canuleius scaber (Piza, 1936) comb. nov.) e a descrição de uma nova espécie para o subgênero Miroceroys. A validade de Ceroys (Miroceroys) é questionada com base nos resultados do trabalho, mas uma conclusão definitiva só poderá ser alcançada com análises complementares de outros gêneros na tribo, especialmente Pygirhynchus Audinet-Serville, 1838 dadas as características compartilhadas entre as espécies presentes nos diferentes gêneros.

Palavras-chave: Brasil. Miroceroys. Neotropical. Taxonomia. 


\begin{abstract}
The genus Ceroys Audinet-Serville 1838 was constituted prior to this study by 15 Neotropical occurring species divided into two subgenera: Ceroys (Ceroys) Audinet-Serville 1838 and Ceroys (Miroceroys) Piza 1936. Previously, the characterization, distribution, behaviour and morphology of some sexes on most of the described species was unknown. Through the detailed analysis of type and complementary material deposited in brazilian and foreign institutions, we present in this thesis the characterization of all 10 occurring brazilian species with description of previously unknown sexes, eggs, ecology and distribution. Morphological and morphometric analysis of individuals and eggs were conducted based on the methodology of recently published research articles about Brazilian Phasmatodea. The male genitalia, as well as the female ovipositor structure, were used to aid in the species characterization. The final result is the synonymization of five of the ten previously known species (Ceroys (Ceroys) multispinosum Audinet-Serville, 1838 syn. nov., Ceroys (Ceroys) albogranulatus Piza 1938 syn. nov. and Ceroys (Ceroys) spinosus Zompro, 2004 syn. nov. under Ceroys (Ceroys) perfoliatus (Gray, 1835); Ceroys (Miroceroys) brunneri Piza, 1936 syn. nov. under Ceroys (Ceroys) cristatus Redtenbacher, 1906; and Ceroys (Miroceroys) redtenbacheri Piza, 1936 syn. nov. under Ceroys (Miroceroys) saevissimus Westwood, 1859), the transfer of one to Canuleius Stål, 1875 (Canuleius scaber (Piza, 1936) comb. nov.) and the description of a new species. The validity of Ceroys (Miroceroys) is questioned based on the achieved results, but a definitive conclusion can only be asserted with complementary analysis, including mainly the species from Pygirhynchus Audinet-Serville, 1838 given the morphological convergences displayed by species on both genera.
\end{abstract}

Keywords: Brazil. Miroceroys. Neotropical. Taxonomy. 


\section{LISTA DE FIGURAS}

Figura 1. Modelo de genitália masculina de Ceroys.

Figura 2. Esquema representativo da estrutura do ovipositor feminino de Ceroys. $\quad 88$

Figura 3. Holótipos de Ceroys (Ceroys) albogranulatus Piza, 1938 syn. nov. e Ceroys (Ceroys) spinosus Zompro, 2004 syn. nov.

Figura 4. Habitus de Ceroys (Ceroys) perfoliatus 90

Figura 5. Detalhes da cabeça de Ceroys (Ceroys) perfoliatus 91

Figura 6. Detalhes do tórax de Ceroys (Ceroys) perfoliatus 92

Figura 7. Detalhes da terminália da fêmea de Ceroys (Ceroys) perfoliatus 93

Figura 8. Detalhes da terminália do macho de Ceroys (Ceroys) perfoliatus 94

Figura 9. Ovo de Ceroys (Ceroys) perfoliatus 95

Figura 10. Casal de Ceroys (Ceroys) perfoliatus in situ 95

Figura 11. Habitus do síntipo de Ceroys (Ceroys) cristatus 96

Figura 12. Habitus de Ceroys (Ceroys) cristatus 97

Figura 13. Detalhes da cabeça de Ceroys (Ceroys) cristatus 98

Figura 14. Detalhes do tórax de Ceroys (Ceroys) cristatus 99

Figura 15. Detalhes da terminália da fêmea de Ceroys (Ceroys) cristatus $\quad 100$

Figura 16. Detalhes da terminália do macho de Ceroys (Ceroys) cristatus 101

Figura 17. Genitália do macho de Ceroys (Ceroys) cristatus 102

Figura 18. Ovo de Ceroys (Ceroys) cristatus 103

Figura 19. Fêmea de Ceroys (Ceroys) cristatus viva in situ 103

Figura 20. Macho de Ceroys cristatus (Ceroys) in situ 104

Figura 21. Variação de cor em um mesmo indivíduo de Ceroys (Ceroys) cristatus de acordo $\begin{array}{ll}\text { com variações de luminosidade ambiente ex situ } & 105\end{array}$

Figura 22. Habitus do holótipo de Ceroys scaber 106

$\begin{array}{ll}\text { Figura 23. Habitus de Canuleius scaber comb. nov. } & 107\end{array}$

$\begin{array}{ll}\text { Figura 24. Detalhes da cabeça de Canuleius scaber comb. nov. } & 108\end{array}$

Figura 25. Detalhes do tórax de Canuleius scaber comb. nov. 109

Figura 26. Detalhes da terminália da fêmea de Canuleius scaber comb. nov. $\quad 110$ 
Figura 27. Detalhes da terminália do macho de Canuleius scaber comb. nov.

Figura 28. Detalhes da genitália do macho de Canuleius scaber comb. nov.

Figura 29. Ovo de Canuleius scaber comb. nov.

Figura 30. Fêmea e macho de Canuleius scaber comb. nov. vivos ex situ

Figura 31. Habitus de Ceroys (Miroceroys) heymonsi

Figura 32. Detalhes da cabeça de Ceroys (Miroceroys) heymonsi

Figura 33. Detalhes do tórax de Ceroys (Miroceroys) heymonsi

Figura 34. Detalhes da terminália da fêmea de Ceroys (Miroceroys) heymonsi

Figura 35. Detalhes da terminália do macho de Ceroys (Miroceroys) heymonsi

Figura 36. Detalhes da genitália do macho de Ceroys (Miroceroys) heymonsi

Figura 37. Ovo de Ceroys (Miroceroys) heymonsi

Figura 38. Macho de Ceroys (Miroceroys) heymonsi vivo in situ

Figura 39. Fêmea de Ceroys (Miroceroys) heymonsi viva in situ

Figura 40. Habitus do holótipo de Ceroys (Miroceroys) saevissimus e Ceroys (Miroceroys) redtenbacheri

Figura 41. Habitus de Ceroys (Miroceroys) saevissimus

Figura 42. Detalhes da cabeça de Ceroys (Miroceroys) saevissimus

Figura 43. Detalhes do tórax de Ceroys (Miroceroys) saevissimus

Figura 44. Detalhes da terminália da fêmea de Ceroys (Miroceroys) saevissimus

Figura 45. Detalhes da terminália do macho de Ceroys (Miroceroys) saevissimus

Figura 46. Detalhes da genitália do macho de Ceroys (Miroceroys) saevissimus

Figura 47. Ovo de Ceroys (Miroceroys) saevissimus

Figura 48. Fêmea de Ceroys (Miroceroys) saevissimus viva ex situ

Figura 49. Macho de Ceroys (Miroceroys) saevissimus vivo ex situ

Figura 50. Habitus de Ceroys (Miroceroys) sp. nov.

Figura 51. Detalhes da cabeça de Ceroys (Miroceroys) sp. nov.

Figura 52. Detalhes do tórax de Ceroys (Miroceroys) sp. nov.

Figura 53. Variações de ornamentação em Ceroys (Miroceroys) sp. nov. 
Figura 55. Detalhes da terminália do macho de Ceroys (Miroceroys) sp. nov.

Figura 56. Detalhes da genitália do macho de Ceroys (Miroceroys) sp. nov.

Figura 57. Ovo de Ceroys (Miroceroys) sp. nov.

Figura 58. Fêmea de Ceroys (Miroceroys) sp. nov. viva in situ

Figura 59. Ninfas de Ceroys (Miroceroys) sp. nov. vivas ex situ

\section{LISTA DE TABELAS}

Tabela 1. Espécies originalmente descritas para Ceroys fora do território brasileiro e/ou de classificação contestada, seu atual estado taxonômico, localidades tipo e paradeiro do material tipo.

Tabela 2. Espécies de Ceroys descritos para território brasileiro, localidades-tipo e local de deposição dos tipos.

Tabela 3. Intervalo de medidas do material analisado de Ceroys (Ceroys) perfoliatus. 142

Tabela 4. Intervalo de medidas dos ovos analisado de Ceroys (Ceroys) perfoliatus. 142

Tabela 5. Intervalo de medidas do material analisado de Ceroys (Ceroys) cristatus. 143

Tabela 6. Intervalo de medidas dos ovos analisados de Ceroys (Ceroys) cristatus.

Tabela 7. Intervalo de medidas do material analisado de Canuleius scaber.

Tabela 8. Intervalo de medidas do material analisado de Ceroys (Miroceroys)

heymonsi.

Tabela 9. Intervalo de medidas dos ovos analisados de Ceroys (Miroceroys)

heymonsi.

Tabela 10. Intervalo de medidas do material analisado de Ceroys (Miroceroys) saevissimus.

Tabela 11. Intervalo de medidas dos ovos analisados de Ceroys (Miroceroys) saevissimus.

Tabela 12. Intervalo de medidas do material analisado de Ceroys (Miroceroys)

sp. nov.

Tabela 13. Intervalo de medidas dos ovos analisados de Ceroys (Miroceroys)

sp. nov. 


\section{SUMÁRIO}

1 - INTRODUÇÃO

1.1 A Mata Atlântica: Hotspot de Biodiversidade Desconhecida 12

1.2 A Situação do Conhecimento sobre Phasmatodea 13

1.3 Heteronemiidae, Diapheromeridae e o Gênero Ceroys Audinet-Serville, $1838 \quad 16$

1.4 O gênero Ceroys Audinet-Serville, $1838 \quad 17$

2 - MATERIAIS E MÉTODOS 20

2.1 Material Examinado $\quad 20$

2.2 Estudo Morfológico e obtenção de Imagens $\quad 21$

3 - RESULTADOS 23

3.1 O Gênero Ceroys 23

3.2 Redescrição do gênero Ceroys Audinet-Serville, 1838

3.3 Chave de Identificação para o Gênero Ceroys 26

3.4 Redescrição do Subgênero Ceroys Audinet-Serville, 1838

3.4.1 Ceroys (Ceroys) perfoliatus (Gray, 1835) 29

3.4.2 Ceroys (Ceroys) cristatus Redtenbacher $1906 \quad 35$

3.4.3 - Canuleius scaber (Piza, 1936) comb. nov. 41

3.5 Redescrição do Subgênero Miroceroys Toledo Piza, 1936

3.5.1 Ceroys (Miroceroys) heymonsi (Piza, 1936) 46

3.5.2 Ceroys (Miroceroys) saevissimus Westwood, 1859

$\begin{array}{ll}\text { 3.5.3 Ceroys (Miroceroys) sp. nov. } & 58\end{array}$

$\begin{array}{ll}3.6 \text { Biologia } & 64\end{array}$

3.7 Comentários sobre o Gênero 65

4 - DISCUSSÃO $\quad 65$

4.1 Caracterização das espécies de Ceroys de Mata Atlântica 65

4.2 Situação e validade dos Subgêneros Ceroys e Miroceroys $\quad 67$

4.3 Comparação e implicações quanto a Pygirhyncus Audinet-Serville $1838 \quad 68$

4.4 Um gênero exclusivo da Mata Atlântica? $\quad 69$

4.5 A Situação de Heteronemiidae $\quad 70$

5 - CONCLUSÃO

6 - BIBLIOGRAFIA

7 - PRANCHAS E TABELAS 


\section{1 - INTRODUÇÃO}

\subsection{A Mata Atlântica: Hotspot de Biodiversidade Desconhecida}

A Mata Atlântica (M.A), segunda maior floresta tropical da América do Sul, é considerada um dos cinco hotspots de diversidade global, apresentando uma das maiores riquezas de espécies dos biomas brasileiros e uma das maiores taxas de endemismo mundial. Esse cenário está possivelmente ligado à heterogeneidade ambiental e a variedade de fitofisionomias que compõem o bioma, como florestas ombrófila densa, ombrófila mista, estacional decidual, semidecidual, manguezais, restingas, campos e florestas de altitude, entre outros (Brown \& Brown, 1992, Myers et al., 2000 Marques et al. 2021). Tendo em vista sua localização, a Mata Atlântica brasileira se encontra hoje fragmentada e desmatada, com cerca de $28 \%$ da cobertura original (Rezende et al. 2018). Na região Sudeste restam cerca de 26\% da cobertura original do bioma, apesar de apenas 11\% serem constituídos de grandes extensões contínuas de cobertura vegetal (Carlucci et al. 2021) A alteração da paisagem está relacionada à ocupação da área pelos colonos portugueses, desenvolvimento da agricultura, pecuária e urbanização: mais da metade da área desmatada é ocupada hoje por pastos e lavouras e cerca de $70 \%$ da população brasileira está em regiões previamente ocupadas pela M.A. (Marques et al. 2021). Essa situação traz uma enorme pressão em relação ao estudo e conservação da área, que vem ganhando interesse crescente de ecólogos, taxônomos e ambientalistas nas últimas décadas. Apesar disso, há um enorme viés relacionado aos estudos de conservação e análise de impactos ambientais já que vertebrados e plantas são os grupos majoritariamente analisados (Pinto et al. 2006, Galetti et al. 2021).

No caso dos invertebrados, Coleoptera e Lepidoptera são os grupos historicamente presentes em estudos de conservação relacionados à M. A. (Myers et al. 2000). Trabalhos recentes com ambos os grupos têm demonstrado a importância da preservação de grandes extensões de vegetação nativa, servindo tanto para a manutenção da diversidade de espécies quanto como reservatório de biodiversidade para áreas adjacentes em menor estado de conservação (Albertoni et al. 2018, Chiquetto-Machado et al. 2018, Huiñocana et al. 2020). De forma similar, esforços têm sido feitos para melhor compreender e acessar a biodiversidade e função de insetos sociais na M.A. dada sua importância na cadeia alimentar e nos processos de polinização e fertilização dos solos (Feitosa et al. 2021). Ainda assim, levando em consideração que os invertebrados podem compor mais de 95\% das espécies presentes no bioma (Myers et al. 2000), o impacto de mudanças de habitat e fragmentação do bioma é virtualmente desconhecido para grande parte da biodiversidade da Mata Atlântica: 
Alguns grupos, como Isoptera, mostram um padrão de distribuição de riqueza inversamente relacionado com a latitude na floresta ombrófila densa, explicado por temperatura, precipitação e eficiência energética (evapotranspiração potencial) (Cancello et al. 2014). Em outros grupos, como no caso de ordens menores e menos estudadas como Phasmatodea, Mantodea, Embioptera, etc. há uma ausência de trabalhos sobre estado de conservação das populações e dinâmicas ecossistêmicas, sendo um potencial reflexo de grande parte da entomofauna do bioma ser desconhecida (Rafael et al. 2009). Essa situação, porém, não é exclusiva da M.A.

Com cerca de 854.000 espécies descritas para o mundo, os insetos constituem mais de $70 \%$ da diversidade de animais já catalogados (Roskov et al. 2018) e são fundamentais para a regulação de ecossistemas terrestres, especialmente nos trópicos (Middleton \& Grace 2004). Apesar de sua enorme diversidade e relevância econômica e ecológica (Rosemberg, 1986) estimativas apontam que apenas $15-20 \%$ das espécies de Hexapoda foram descritas, sendo necessário um esforço urgente no estudo de táxons menos estudados (Stork et al. 2015, Stork 2018). Estudos recentes reforçam o impacto do desconhecimento sobre o grupo em estudos relacionados às suas populações ao redor do globo e as consequências da perda de habitat, contaminação da água e solo e mudanças climáticas (Didham et al. 2020, Wagner et al. 2021). Se faz necessário um esforço urgente para melhor compreender os insetos, em especial ordens menores, mal amostradas e pouco conhecidas. É entre elas que encontramos os bichos-pau, organismos crípticos e ainda relativamente pouco estudados.

\subsection{A Situação do Conhecimento sobre Phasmatodea}

Os representantes da ordem Phasmatodea são popularmente conhecidos como bichos-pau dada a sua semelhança morfológica com ramos de plantas e folhas. São insetos exclusivamente herbívoros de hábitos noturno que tendem a permanecer imóveis durante o dia (Bedford, 1978). Entretanto, há espécies da ordem que são diurnas e possuem coloração aposemática (Eisner et al. 1997, Bradler 2009). Apesar de imediatamente associados à sua camuflagem, a ordem também apresenta outras adaptações marcantes como: são junto de Chrysomelidae os únicos insetos obrigatoriamente herbívoros, sendo capazes de digerir lignina sem auxílio de organismos endossimbiontes (Shelomi et al. 2014), incluem alguns dos poucos representantes de Arthropoda capazes de ativamente mudar a pigmentação corporal de acordo com estímulos do ambiente para se camuflarem (Bedford 1978, Gustafson 1966, Umber et al. 2014, Engelking, comunicação pessoal), seus ovos apresentam adaptações de dispersão similares às vistas em plantas (Compton \& Ware 1991, Hughes \& Westoby 1992, 
Suetsugo et al. 2018), entre outros. São conhecidas atualmente 3.411 espécies válidas distribuídas em sua maioria em regiões tropicais e subtropicais (Brock, et al. 2021). Para o Brasil são descritas 217 espécies (Brock et al. 2021), o equivalente a 6\% da fauna mundial, com uma riqueza estimada em ao menos 600 espécies para o país (Zompro, 2012).

Antigamente classificados como um subgrupo de Orthoptera (Westwood 1859; Kirby 1904), a classificação atual coloca Phasmatodea como ordem inserida no clado Polyneoptera (Boudreaux 1979) e sustentada por dados moleculares (Whiting et al. 2003; Plazzi et al. 2011; Tomita et al. 2011). Apesar de anteriormente contestada (Whiting 2002; Kjer 2004; Terry \& Whiting 2005; Cameron et al. 2006; Kjer et al. 2006; Whitfield \& Kjer 2008), a maior parte das análises recentes recupera a monofilia de Polyneoptera (Wheeler et al. 2001; Willmann 2004; Gullan \& Cranston 2005; Grimaldi \& Engel 2005; Bradler 2009; Trautwein et al. 2012; Letsch \& Simon 2013; Misof et al. 2014), bem como o posicionamento de Phasmatodea como grupo irmão de Embioptera (Whiting et al. 2003; Bradler 2009; Friedemann et al. 2012; Trautwein et al. 2012; Letsch \& Simon 2013; Misof et al. 2014).

A situação filogenética dentro da ordem é inconclusiva, sendo uma das últimas dentro de Insecta a não possuir um consenso básico das relações infra-ordinais (Bradler 2009, Robertson et al. 2018, Simon et al. 2019). Essa situação se deve em parte à forma como o grupo foi historicamente trabalhado.

A obra de Redtenbacher e Brunner von Wattenwyl (publicada em três volumes: Redtenbacher 1906, 1908; Brunner von Wattenwyl, 1907) é um marco para a ordem, dividindo-a em tribos e apresentando descrições sistematizadas de espécies de diferentes localidades do Globo. Outros naturalistas e pesquisadores como Stål (1858; 1875a, b, c; 1876; 1877a, b), Berthold (1827), Audinet-Serville (1831, 1838; Latreille et al. 1825, 1828;), Saussure $(1859 ; 1861 ; 1862 ; 1868 \mathrm{a}, \mathrm{b} ; 1862 ; 1872)$, entre outros, fizeram importantes contribuições para o estudo de bichos-pau. Günther (1953) apresentou uma reorganização das famílias e tribos e Bradley \& Galil (1977) introduziram como subordens os agrupamentos Areolatae e Anareolatae. São caracterizados respectivamente pela presença e ausência da area apicalis, uma região esclerotizada ou membranosa localizada ventro-apicalmente nas tíbias. Embora artificiais (Zompro 2004a,b; Bradler 2009; Kômoto et al. 2011; Bradler et al. 2014), estes agrupamentos foram apenas recentemente abandonados, deixando Phasmatodea carente de agrupamentos infraordinais e suprafamiliares enquanto não há consenso na literatura (Brock et al. 2021, Robertson et al. 2018; Simon et al. 2019; Tihelka et al. 2020; Forni et al. 2021).

A situação é consequência direta de um refinamento e ampliação tardia de caracteres utilizados em trabalhos taxonômicos a partir da década de 90 do século passado: Sellick 
(1988, 1994, 1997 a,b, 1998) estudou de forma detalhada os ovos de Phasmatodea demonstrando seu valor taxonômico. Helm (2011) padronizou as estruturas da genitália masculina, superficialmente explorada no passado e ainda pouco utilizada em Phasmatodea (Ghirotto, 2021) apesar de consagrada no estudo de Hexapoda (Boudinot, 2018). A observação e estudo de animais in situ e em cativeiro e do refinamento de estudos de bases moleculares permitiu a realização de diversos estudos filogenéticos recentes (Bradler, 2009, Whiting et al., 2003; Kômoto et al. 2011; Bradler et al., 2014; Goldberg et al., 2015, Brock et al. 2021, Robertson et al. 2018; Simon et al. 2019; Tihelka et al. 2020; Forni et al. 2021) que sistematicamente contestavam os agrupamentos tradicionais de Phasmatodea. Novas descobertas relacionadas ao registro fóssil da ordem têm também auxiliado no debate sobre o surgimento do grupo e suas relações filogenéticas (Wedmann et al. 2007, Engel \& Wang, 2016, Chen et al. 2018, 2019, Yang et al. 2021, Ghirotto et al. submetido). Entretanto, a baixa amostragem de fósseis, sua natureza fragmentária, situação taxonômica confusa, entre outros, torna o uso de fósseis como ferramentas de calibração um desafio (Ghirotto et al. submetido).

Antes disso, grande parte dos trabalhos se baseavam em caracteres morfológicos externos, que ainda são amplamente utilizados para caracterização dos táxons (Bacetti, 1987; Tilgner et al., 1999; Bradler, 2003; Grimaldi \& Engel, 2005; Friedemann et al. 2012, Gutiérrez-Valencia et al. 2017). Tal situação resultou em diversas descrições baseadas em poucos, senão um único indivíduo. Pequenas variações morfológicas e o acentuado dimorfismo sexual resultaram em inúmeras descrições de gêneros altamente heterogêneos como Bacteria Berthold, 1827 e Canuleius Stål, 1875, como exemplificado em Crispino et al. (2021). Cerca de 180 dos 480 gêneros descritos (35\% do total) são monotípicos (Bradler \& Buckley 2018) e por vezes baseados exclusivamente em um único sexo (exemplificados por Conle, Hennemann \& Gútierrez 2011, Hennemann \& Conle 2006, 2020, Zompro 2004a, Cumming et al. 2020, entre outros). Diferentes famílias dentro da ordem são consideradas polifiléticas (Bradler 2009, Robertson et al. 2018, Simon et al. 2019). A alta polimorfia intraespecífica (exemplificada em Gútierrez-Valença et al. 2017 e Crispino et al. 2020) e convergências entre táxons não relacionados (Bradler \& Buckley 2018) resultou também nas proposta de diversas sinonímias (exemplificado por Conle et al. 2020, Crispino et al. 2020, Hennemann \& Conle 2020, entre outras).

É nessa situação que grande parte das famílias, gêneros e espécies neotropicais se encontram, principalmente brasileiros: taxonomicamente confusos, mal delimitados e carecendo de urgente estudo (Zompro, 2004 a, b Bradler \& Buckley 2018). À parte de trabalhos de pesquisadores estrangeiros, Salvador de Toledo Piza Júnior foi um dos únicos entomólogos brasileiros a trabalhar com Phasmatodea, descrevendo 45 espécies do Brasil 
(Toledo Piza, 1936a, b; 1937; 1938a, b; 1939; 1943; 1944; 1946; 1977 e 1985a, b). Após seu falecimento, novas publicações envolvendo a descrição e revisão de bichos-pau em território nacional voltaram a ocorrer somente após o ano 2000 (Madeira-Ott et al. 2020, Ghirotto 2021, Chiquetto-Machado \& Cancello 2021). A família Heteronemiidae, onde as espécies trabalhadas nesta dissertação estão alocadas, sumariza perfeitamente os problemas mencionados.

\subsection{Heteronemiidae, Diapheromeridae e o Gênero Ceroys Audinet-Serville, 1838}

Criada por Rehn (1904), a família Heteronemiidae antes englobava as espécies que hoje se encontram em Diapheromeridae. A separação destas famílias ocorreu com a justificativa de que tanto espécies pertencentes aos Areolatae quanto à Anareolatae estavam agrupadas erroneamente na mesma família (Zompro 2001 a,b, Zompro 2004 a,b). Dessa forma, Zompro manteve em Heteronemiidae apenas as espécies que possuíam area apicalis, movendo as demais para Diapheromeridae.

Da forma como se encontra hoje, Heteronemiidae foi caracterizada por Zompro (2004b) como tendo representantes ápteros, com corpos alongados especialmente na região toráxica, com cabeças mais longas que o protórax e normalmente possuindo dois tubérculos entre os olhos. Outras características incluem a ausência de ocelos como todos os bichos-pau ápteros e a forma de seus antenômeros, triangulares em sessão transversal a partir do terceiro. O póculo (placa subgenital masculina formada pelo esternito abdominal IX) normalmente apresenta um apêndice posteroventral, enquanto a placa subgenital das fêmeas normalmente termina às margens ou após o abdômen. Compreende uma única subfamília, Heteronemiinae, dividida em três tribos: Heteronemiini, Paraleptyniini e Pygirhynchini. É nesta última onde Ceroys, o gênero foco dessa dissertação, está classificado. A tribo é, nas palavras de Zompro (2004b) “...mais similar à descrição de Heteronemiidae do que os próprios Heteronemiidae”. Além das características já mencionadas, costumam ter o segmento mediano (primeiro segmento abdominal fusionado ao tórax) comparativamente curto em relação ao corpo, coloração opaca e comumente apresentam ornamentação em forma de espinhos, tubérculos, grânulos e projeções foliáceas. É a maior das tribos de Heteronemiidae, com quatro gêneros (Canuleius Stål, 1875; Ceroys Audinet-Serville, 1838; Paraceroys Conle, Hennemann \& Gutiérrez, 2011 e Pygirhynchus Serville, 1838) e 45 espécies válidas.

À luz dos problemas mencionados, falta de caracterização aprofundada e ausência de informação com o gênero, este trabalho irá caracterizar morfologicamente as espécies descritas para a região de Mata Atlântica do gênero Ceroys com seus subgêneros Ceroys 
(Ceroys) Audinet-Serville, 1838 e Ceroys (Miroceroys) Piza, 1936. Representantes do gênero Pygirhynchus Audinet-Serville, 1838 foram analisados de forma complementar.

\subsection{O gênero Ceroys Audinet-Serville, 1838}

Endêmico da região Neotropical, o gênero compreende 15 espécies de bichos-pau ápteros de médio porte com corpo robusto e ornamentado em variáveis níveis com espinhos, lóbulos, projeções foliáceas e tubérculos (Zompro 2004, Brock et al. 2021, Tabelas 1 e 2). Como mencionado anteriormente, descrições historicamente vagas e anatomia convergente resultaram em diversas espécies da Colômbia, Peru, Guiana, Brasil, Nicarágua, México, entre outros, erroneamente descritas em Ceroys desde o Século XIX. Com exceção das espécies brasileiras, quase todas as demais foram transferidas para outros gêneros e famílias (Tabela 1). As espécies que não ocorrem na região Sul/Sudeste do Brasil e permanecem no gênero se encontram ou em situação dúbia (Conle et al. 2011; O. V. Conle, comunicação pessoal) ou desprovidas de material tipo (Tabela 1). Já entre os representantes nacionais, são encontradas espécies de ambos os subgêneros descritos: Ceroys (Ceroys) Audinet-Serville 1838, cuja espécie tipo Ceroys (Ceroys) perfoliatus Audinet-Serville, 1838 é endêmica da Mata Atlântica do Estado do Rio de Janeiro; e Ceroys (Miroceroys) Toledo Piza, 1936, descrito originalmente como um gênero com base na espécie Ceroys (Miroceroys) redtenbacheri (Piza, 1936) (tabela 2) e posteriormente rebaixado a subgênero por Zompro, que contesta a validade do gênero (Zompro 2004b). Estão restritos a regiões de Mata Atlântica dos estados de São Paulo, Rio de Janeiro, Minas Gerais e Paraná. Considerando o elevado grau de endemismo de espécies da Mata Atlântica (Brown, 1991), a situação já mencionada das espécies descritas para outros países e o monitoramento de cerca de cerca de 6500 registros fotográficos de Ciência Cidadã de bichos-pau da América do Sul do Projeto Phasma via o projeto "Stick-Insects of South América" no iNaturalist (https://www.inaturalist.org/projects/stick-insects-of-south-america), o gênero Ceroys aparentemente é endêmico das regiões de Mata Atlântica do Sudeste Brasileiro. De toda forma, mais estudos são necessários envolvendo a tribo como um todo para que tais afirmações sejam validadas. 
Tabela 1: Espécies originalmente descritas para Ceroys fora do território brasileiro e/ou de classificação contestada, seu atual estado taxonômico, localidades tipo e paradeiro do material tipo.

\begin{tabular}{|c|c|c|c|}
\hline Classificação Original & Classificação Atual & Localidade Tipo & Depositório(s) \\
\hline Ceroys auritus Piza, 1936 & $\begin{array}{c}\text { Pygirhynchus } \\
\text { toledopizai (Zompro, } \\
\text { 2004) }\end{array}$ & $\begin{array}{c}\text { Alto da Serra, } \\
\text { Paranapiacaba, Brasil }\end{array}$ & MZUSP \\
\hline $\begin{array}{c}\text { Ceroys baculus (Saussure, } \\
\text { 1859) }\end{array}$ & $\begin{array}{c}\text { Ceroys baculus } \\
\text { (Saussure, 1859) }\end{array}$ & América do Sul & MHNG \\
\hline $\begin{array}{c}\text { Ceroys bigibbus Rehn, } \\
1904\end{array}$ & $\begin{array}{c}\text { Rhynchacris bigibbus } \\
\text { (Rehn, 1904) }\end{array}$ & Nicarágua & USNM \\
\hline $\begin{array}{c}\text { Ceroys brevicornis Conle, } \\
\text { Hennemann \& Gutiérrez, } \\
2011 \\
\end{array}$ & $\begin{array}{c}\text { Ceroys brevicornis } \\
\text { Conle, Hennemann \& } \\
\text { Gutiérrez, } 2011 \\
\end{array}$ & $\begin{array}{c}\text { Colômbia, Restrepo, Valle } \\
\text { del Cauca, Vereda Río } \\
\text { Bravo } \\
\end{array}$ & ICN Bogotá \\
\hline C. capreolus Kaup, 1871 & $\begin{array}{l}\text { Sermyle mexicana } \\
\text { (Saussure, 1859) }\end{array}$ & México & MHNG \\
\hline $\begin{array}{l}\text { Ceroys columbina } \\
\text { Westwood, } 1859\end{array}$ & $\begin{array}{l}\text { Libethra columbina } \\
\text { (Westwood, 1859) }\end{array}$ & Colômbia & UMO Oxford \\
\hline $\begin{array}{l}\text { Ceroys coronatus } \\
\text { (Thunberg, 1815) }\end{array}$ & $\begin{array}{l}\text { Ceroys coronatus } \\
\text { (Thunberg, 1815) }\end{array}$ & Desconhecida & $\begin{array}{c}\text { Desconhecido/ } \\
\text { Perdido }\end{array}$ \\
\hline $\begin{array}{l}\text { Ceroys histrinus } \\
\text { Westwood, } 1859\end{array}$ & $\begin{array}{l}\text { Creoxylus histrinus } \\
\text { (Westwood, 1859) }\end{array}$ & Venezuela & NHMUK \\
\hline $\begin{array}{c}\text { Ceroys ignavus } \\
\text { Westwood, } 1859 \\
\end{array}$ & $\begin{array}{l}\text { Lobolibethra ignava } \\
\text { (Westwood, 1859) }\end{array}$ & Brasil, Tapajós & NHMUK \\
\hline $\begin{array}{l}\text { Ceroys laciniatus } \\
\text { Westwood, } 1874\end{array}$ & $\begin{array}{c}\text { Trychopeplus } \\
\text { laciniatus (Westwood, } \\
1874 \text { ) } \\
\end{array}$ & Nicarágua & UMO Oxford \\
\hline $\begin{array}{c}\text { Ceroys linearis Saussure, } \\
1868 \\
\end{array}$ & $\begin{array}{l}\text { Sermyle linearis } \\
\text { (Saussure, 1868) }\end{array}$ & América do Sul & MHNG/Perdido \\
\hline Ceroys lituus Rehn, 1904 & $\begin{array}{c}\text { Ceroys lituus Rehn, } \\
1904\end{array}$ & $\begin{array}{c}\text { Guiana, Demerara (região } \\
\text { litorânea que compreende } \\
\text { Georgetown) }\end{array}$ & ANSP/Perdido \\
\hline $\begin{array}{c}\text { Ceroys pusillus } \\
\text { Redtenbacher, } 1906\end{array}$ & $\begin{array}{c}\text { Ceroys pusillus } \\
\text { Redtenbacher, } 1906\end{array}$ & Peru & MHNG \\
\hline $\begin{array}{l}\text { Ceroys quadrispinosus } \\
\text { Redtenbacher, } 1906\end{array}$ & $\begin{array}{c}\text { Paraceroys } \\
\text { quadrispinosus } \\
\text { (Redtenbacher, 1906) } \\
\end{array}$ & Colômbia & NMW \\
\hline $\begin{array}{c}\text { Ceroys rabdota Westwood, } \\
1859 \\
\end{array}$ & $\begin{array}{l}\text { Libethra rabdota } \\
\text { (Westwood, 1859) }\end{array}$ & Colômbia & UMO Oxford \\
\hline
\end{tabular}


Tabela 2: Espécies de Ceroys descritos para território brasileiro, localidades-tipo e local de deposição dos tipos. Ceroys $($ Ceroys $)=C$. sp. e Ceroys (Miroceroys $)=M$. sp.

\begin{tabular}{lcc}
\hline \multicolumn{1}{c}{ Espécie } & Localidade(s) Tipo & Depositório(s) \\
\hline C. perfoliatus (Gray, 1835) & Brasil & NHMUK \\
\hline C. multispinosum Serville, 1838 & Brasil & UMO Oxford \\
\hline C. cristatus Redtenbacher, 1906 & Brasil & NMW \\
\hline C. scaber Toledo Piza, 1936 & Brasil, São Paulo, Paranapiacaba & MZUSP \\
\hline C. albogranulatus Toledo Piza, & Brasil, São Paulo, Paranapiacaba & MZUSP \\
1938 & Brasil, São Paulo, Paranapiacaba & MZUSP \\
\hline C. spinosus Zompro, 2004 & (Alto da Serra) & NHMUK \\
\hline M. saevissimus Westwood, 1859 & Brasil & MZUSP \\
\hline $\begin{array}{l}\text { M. redtenbacheri (Toledo Piza, } \\
\text { 1936) }\end{array}$ & Brasil, Rio de Janeiro & \\
\hline M. heymonsi (Toledo Piza, 1936) & Brasil, São Paulo, Paranapiacaba & MZUSP \\
\hline M. brunneri Toledo Piza, 1936 & Brasil, Rio de Janeiro, Macaé & MZUSP \\
\hline
\end{tabular}

Dessa forma, essa dissertação visa apresentar uma caracterização morfológica detalhada de Ceroys e suas espécies de Mata Atlântica. São descritos e/ou redescritos exemplares de ambos os sexos, ovos e estágios de vida antes desconhecidos de todas as espécies do gênero. Pygirhynchus Serville, 1838, considerado o "gênero irmão" (Zompro, 2004b) e que incluí ao menos uma espécie originalmente descrita em Ceroys (Tabela 1) também foi analisado como material complementar a fim de comparar caracteres morfológicos e ecológicos convergentes, auxiliando na delimitação dos gêneros e espécies. Os resultados aqui apresentados não só auxiliarão trabalhos futuros como também fornecem uma base teórica para a revisão das espécies remanescentes descritas fora da área de Mata Atlântica. 


\section{2 - MATERIAIS E MÉTODOS}

\subsection{Material Examinado}

Neste trabalho foi examinado o material de dez instituições nacionais e estrangeiras através de visitas a coleções, uso de fotos de holótipos digitalizados e/ou empréstimo de material. O nome das instituições e seus acrônimos são listados a seguir:

ANSP: Academy of Natural Sciences of Philadelphia - Filadélfia, Pensilvânia, Estados Unidos;

IBSP: Instituto Biológico de São Paulo - São Paulo, São Paulo, Brasil;

ICN: Instituto de Ciencias Naturales de la Universidad Nacional de Colombia Bogotá, Colômbia;

MELQ: Museu Entomológico Luiz de Queiroz - Piracicaba, São Paulo, Brasil;

MHNG: Muséum d'Histoire Naturelle de la Ville de Genève - Genebra, Suíça;

MZUSP: Museu de Zoologia da Universidade de São Paulo - São Paulo, São Paulo, Brasil;

NHMUK: Natural History Museum - Londres, Reino Unido;

NMW: Naturhistorisches Museum Wien - Viena, Áustria;

UMO: Oxford University Museum of Natural History - Londres, Reino Unido;

USNM: National Museum of Natural History - Washington, Estados Unidos.

Materiais tipo analisados nesta dissertação se encontram depositados a seco nas coleções do entomológicas do MZUSP, IBSP e MELQ, contabilizando seis espécimes pertencentes ao gênero Ceroys e três à Pygirhynchus. Espécimes depositados no IBSP foram analisados via empréstimo do material, enquanto os depositados no MELQ foram analisados na própria coleção. Espécimes tipos depositados no NHMUK, UMO e NMW foram analisados através de fotos detalhadas disponíveis no Phasmida Species File (Brock et al. 2021) ou tiradas e fornecidas por Pablo Vallero. Material não tipo das coleções do MZUSP e MELQ foram analisadas, contabilizando cento e dezoito espécimes pertencentes ao gênero Ceroys e quarenta e três à Pygirhynchus. Registros complementares de Ceroys e Pygirhynchus in situ disponíveis em "bichos-pau do Brasil", uma iniciativa de pesquisa e ciência cidadã do Projeto Phasma (https://www.researchgate.net/project/Projeto-Phasma) e disponibilizadas através do iNaturalist, uma iniciativa de ciência cidadã e extensão da National Geographic Society e California Academy of Science, foram utilizados para complementação da caracterização de espécimes vivos, além da distribuição e registros de ocorrência. 
Parte do material analisado foi coletado entre 2017 e 2021 em campanhas na Estação Biológica de Boracéia do MZUSP, Parque Estadual de Intervales, Parque Nacional do Itatiaia e da Reserva Natural SESC Bertioga. O material foi coletado em buscas ativas e predominantemente noturnas em diferentes fitofisionomias de Mata Atlântica. Adultos coletados dessa forma foram mantidos vivos em cativeiro para obtenção de ovos, observação do ciclo de vida, maturação e obtenção de informações relacionadas a biologia e ecologia de cada espécie. Cada terrário era composto de uma caixa organizadora de 20 litros com tampa telada, forrada com uma mistura de terra, vermiculita e sphagnum, adaptando o protocolo utilizado por colaboradores estrangeiros (http://phasmatodea.com/about-phasmid-breeding). Diferentes plantas silvestres e nativas foram mantidas nos terrários como alimento, dentre elas Psidium guajava e Eugenia uniflora (Myrtaceae), Piper umbellatum (Piperaceae), Ludwigia sp. (Onagraceae) e diferentes samambaias. Adultos foram fixados a seco após morte (natural ou sacrificados com auxílio de pote mortal com acetato de etila ou congelamento) e depositados na coleção entomológica do Museu de Zoologia da Universidade de São Paulo.

Ovos obtidos através de fêmeas adultas foram incubados seguindo o protocolo disponível em www.phasmatodea.com, (site de pesquisa e divulgação mantido por pesquisadores estrangeiros dedicado ao estudo de bichos-pau) sendo acomodados em pequenos recipientes com tampa telada e forrados com sphagnum úmido, protegidos de luz direta, até a eclosão. Parte dos ovos foi congelada, seca em estufa e depositada conjuntamente com a fêmea de origem na coleção entomológica do MZUSP. Ninfas coletadas e/ou provenientes de ovos incubados foram mantidas em cativeiro para maturação, permitindo a observação e descrição do ciclo de vida de diferentes espécies.

\subsection{Estudo Morfológico e obtenção de Imagens}

Caracteres da morfologia externa comumente estudados em Phasmatodea foram analisados (como em Crispino et al. 2020, Chiquetto-Machado \& Cancello 2021, Ghirotto 2021) sendo eles: Proporções morfológicas, análise dos padrões de ornamentação, morfologia dos segmentos antenais, estruturação do ovipositor da fêmea, morfologia da genitália do macho, anatomia da cápsula do ovo, entre outros. Estruturas das antenas, pernas, genitália masculina, terminália da fêmea e ovos foram analisados não apenas por conta de sua importância taxonômica e utilidade na caracterização das espécies, mas também porque uma parte expressiva desses caracteres é desconhecida para grande parte dos bichos-pau (Ghirotto, 2021). 
Os tarsos, as peças bucais, a ornamentação corporal e a cápsula do ovo foram analisadas com auxílio de estereomicroscópio Leica M125 com retícula micrométrica e paquímetro digital de três botões King Tools para observação e medição de estruturas. Um estereomicroscópio Zeiss SteREO Discovery.V12 com câmera acoplada Zeiss MRc5e foi utilizado para realização de fotos em camada de estruturas de interesse como genitália, ovos, antenômeros, entre outros, e processadas com o software Helicon Focus version 6.3.7 Pro e Adobe Photoshop 2020. As fotos de espécimes vivos em cativeiro e in situ e depositados nas coleções entomológicas foram feitas utilizando Canon EOS Rebel T5 equipada com lentes Canon EF-S 18-55 mm, Canon EOS Rebel SL1 equipada com lentes Canon EF $100 \mathrm{~mm}$ F/2.8 Macro USM. As ilustrações e os esquemas foram feitos com auxílio de uma mesa digitalizadora Huion H320M e Adobe Photoshop 2020.

A dissecção da genitália interna segue a técnica utilizada com ortópteros preservados em via seca, na qual apenas a porção final do abdômen é imersa e reidratada em água aquecida, minimizando o dano ao exemplar (Roberts, 1941). Após isso, a genitália é removida por meio de incisões laterais nos últimos segmentos abdominais e fervida em solução de $\mathrm{KOH}$ a 10\% (Camousseight, 1995; Helm et al., 2011) pelo tempo necessário para clareamento e amolecimento da musculatura. Após lavagem em álcool 70\% e remoção de traqueias e músculos, a genitália foi preservada em um pequeno tubo com glicerina junto ao espécime de origem.

A descrição de cores foi baseada em registros de espécimes vivos fotografados em campo ou submetidos na plataforma iNaturalist, sob identificação do projeto "bichos-pau do Brasil" (https://www.inaturalist.org/projects/bichos-pau-do-brasil). Seguindo a metodologia de Chiquetto-Machado (2018), o segmento mediano não foi incluído como parte do abdômen na realização de descrições e medições. Para descrever estruturas da terminália de material seco, a região apical do abdome de alguns exemplares foi imersa em banho maria por alguns minutos para permitir uma melhor material. Dessa forma, cercos, escleritos e outras estruturas ficavam mais fáceis de serem manipuladas, preparadas, fotografadas e dissecadas.

A terminologia de ovos segue a proposta por Clark Sellick (1997), orgão fálico masculino segue a nomenclatura de Ghirotto (2021), que apresenta uma adequação à proposta por Helm et al. (2011) e Chiquetto-Machado \& Cancello (2021) e as estruturas da terminália da fêmea seguem a nomenclatura de Bradler (2009) e Vallotto et al. (2016). Ninfas são brevemente descritas com base no material depositado na coleção entomológica do MZUSP, além de fotos de indivíduos vivos observados em campo e/ou mantidos em cativeiro. 


\section{3 - RESULTADOS}

\subsection{O Gênero Ceroys}

O gênero Ceroys compreende bichos-pau de pequeno a médio porte que são distinguíveis dos demais gêneros da tribo (Pygirhyncus e Canuleius) por suas cabeças pequenas e proporcionais ao pronoto, ornamentação corporal com espinhos torácicos, lóbulos irregulares e anatomia da terminália: Nas fêmeas os segmentos IX e X são mais curtos e elevados dorsalmente, apresentando sempre uma ornamentação em formato ou crista na margem posterior do segmento IX. Já os machos apresentam os segmentos abdominais VIII-X mais robustos e alargados, também com uma elevação dorsal. São insetos de cores crípticas, raramente apresentando cores fora do espectro do marrom, verde e bege. Seus ovos também apresentam uma anatomia distinta, com a cápsula apresentando padrões geométricos em formatos de hexágonos irregulares e cristas elevadas e porosas. Em contraponto, as fêmeas de Pygirhyncus são muito mais robustas, com cabeças largas e retangulares, além de sempre apresentarem alongamentos do segmento abdominal $\mathrm{X}$ e placa subgenital, formando uma estrutura que auxilia no hábito de oviposição. Os machos são muito mais delicados que os de Ceroys, sendo esguios e desprovidos de ornamentação. Os ovos de Pygirhyncus também são densamente pilosos, alongados e desprovidos dos poros nas cristas ou padrões geométricos bem estabelecidos. Canuelius, por sua vez, são muito mais robustos e longos, com terminálias alongadas em ambos os sexos e ornamentações muito mais simples, normalmente constituídas de espinhos cônicos lisos simples e coloridos. Os machos costumam ser coloridos, com faixas ao longo do tórax que vão do vermelho ao amarelo, e os tons de verde por vezes beiram o azul. Além disso, os ovos das fêmeas são pilosos e apresetam uma pseudocapítulo em formato de cesto que não é encontrado nos demais grupos, além de ornamentações bem desenvolvidas na margem da placa micropilar. Também não possuem poros em suas cristas da cápsula do ovo.

\subsection{Redescrição do gênero Ceroys Audinet-Serville, 1838}

\section{Descrição:}

Bichos-pau de tamanho médio, ápteros e com acentuado dimorfismo sexual. O corpo é opaco, granuloso e com superfície irregular, comumente apresentando pequenos tubérculos,

espinhos e projeções foliáceas no tórax, pernas e abdômen (Figuras 4, 6, 31, 33). Cores variam de marrom escuro e bege a diferentes tons de verde, com olhos normalmente amarelados, arredondados, projetados lateralmente e por vezes apresentando uma faixa 
horizontal escurecida (Figuras 10, 48, 49, 58). O ventre costuma apresentar tons mais claros que o dorso, e muitas espécies possuem linhas medianas e manchas abdominais que variam entre o preto, bege creme e tons de cinza. Grânulos, espinhos e outras ornamentações normalmente apresentam a mesma coloração do corpo, com suas extremidades variando entre tons de laranja e bege creme.

Na cabeça, o vértex é elevado, especialmente nas fêmeas (Figuras 5, 13, 32, 42, 51), e ornamentado com um par de espinhos orientados lateralmente, muitas vezes tuberculados e de margem irregular, achatados dorsoventralmente. As antenas são longas e filiformes apresentando entre vinte e dois e vinte e cinco antenômeros, escapo retangular, mais longo do que largo e achatado dorsoventralmente podendo apresentar espinhos na porção distal. $\mathrm{O}$ pedicelo é cilíndrico, enquanto os flagelômeros são triangulares em seção transversal, ficando gradativamente mais cilíndricos e alongados normalmente a partir do décimo oitavo flagelômero. Todas as espécies apresentam um abaulamento dorsal pequeno, conspícuo e desprovido de cerdas entre os décimo primeiro e décimo quarto flagelômero (Figuras $5 \mathrm{G}, \mathrm{H}$; $13 \mathrm{G} ; 32 \mathrm{G}, \mathrm{H} ; 42 \mathrm{G}, \mathrm{H}$;). Os olhos compostos são quase perfeitamente redondos, levemente afunilados anteriormente e se projetando lateralmente, proporcionalmente maiores nos machos do que nas fêmeas. Não possuem ocelos. Os palpos labiais e maxilares robustos, com segmentos ovais e arredondados, achatados dorsoventralmente em ambos os sexos.

O pronoto é desprovido de aberturas protorácicas visíveis e normalmente em formato de sela, com uma sutura mediana bem demarcada. O sulco furcasternal é conspícuo, localizado medianamente na face ventral do pronoto. $\mathrm{O}$ meso- e metatórax normalmente apresentam um ou mais pares de espinhos assimétricos, além de projeções dorsais lateralmente orientadas de formato lanceolado e de margens irregulares (Figuras $3 \mathrm{~A}, \mathrm{~B} ; 4 \mathrm{~A}$, B; 5 C; 10; 11, 12 A, B; 13 B, D; 14 A, B; 19; 20; 21 A-D; 31 A, B; 32 C, D; 33 A, B; 38; 39; 40 A, B; 41 A, B; 42 A-D; 43 A, B; 48; 49; 50 A, B; 51 C, D; 52 A, B). O segmento mediano é reduzido, cerca de 2 a 3,3 vezes menor que o metanoto, muitas vezes antecedido por um par de espinhos dorsais na margem posterior do metanoto (Figuras 6, 14, 33, 43, 52).

Pernas são longas e esguias, com o fêmur e tíbias apresentando um formato trapezóide em seção transversal tão acentuado que facilmente podem ser confundidas como sendo triangulares. Normalmente apresentam ornamentações nos fêmures e tíbias, entre espinhos, áreas serrilhadas e lóbulos foliáceos (Figuras 4, 12, 31, 41, 50). Profêmur apresenta um achatamento em sua porção mais basal que permite aos indivíduos acomodar a cabeça entre as pernas de forma a melhor se camuflar com o ambiente. As tíbías apresentam um inchaço em sua porção posterior, logo antes da articulação com o basitarso, onde se encontra a area apicalis de formato triangular, margeada por cerdas. Normalmente são de mesmo tamanho ou 
maiores que os fêmures correspondentes. O metafêmur e metatíbia são maiores que o profêmur e protibia. Mesofêmur e metatíbia são os menores dos três pares. O último par de pernas ultrapassa o fim do abdômen quando esticadas posteriormente em ambos os sexos. $\mathrm{O}$ basitarso é menor que os 4 tarsomeros restantes combinados.

O abdômen é levemente maior que a cabeça, tórax e segmento mediano combinados, sendo os segmentos II-VI mais largos que longos, VII-X tão longos quanto largos, com segmentos abdominais gradualmente ficando mais curtos a partir do segmento $\mathrm{V}$ (Figuras (Figuras 4, 11, 12, 19, 20, 21,31, 38, 39, 40, 41, 48, 49, 50, 53, 58). Segmentos II-VII normalmente apresentam alguma forma de constrição central. Nas fêmeas o segmento IX normalmente se projeta sobre a porção anterior do segmento $\mathrm{X}$ formando uma escama característica do gênero. Tergito VIII posteriormente elevado; IX significantemente mais alto que os demais segmentos, enquanto o tergito $\mathrm{X}$ apresenta uma elevação em sua margem anterior, gradualmente afinando em sua margem posterior e recobrindo os cercos e epiprocto. O segmento X é curto, truncado, normalmente apresentando margens irregulares. Nas fêmeas o paraprocto é curto, curvado interiormente, enquanto o é epiprocto triangular, quilhado e largo (Figuras 7, 15, 34, 44, 54). Machos possuem o segmento abdominal VIII alargado lateralmente em sua porção posterior, gradativamente afunilando nos segmentos abdominais IX e X. Segmento abdominal VIII-X notavelmente elevados dorsalmente em relação aos demais. A placa subgenital é bem desenvolvida e quilhada medianamente, apresentando uma margem posterior bem delimitada, especialmente onde se funde com a quilha mediana. $\mathrm{O}$ vômer é triangular e simples, normalmente com uma pequena ponta esclerotizada. Os cercos são levemente curvados para dentro, pilosos, enquanto o tergito abdominal $\mathrm{X}$ costuma apresentar uma margem distal levemente bífida com placas dentadas (Figuras 8, 16, 35, 45, 55). Os cercos são curtos e cilíndricos nas fêmeas, com ápice cônico, apresentando certas curtas, normalmente com um terço do tamanho do tergito X. Em machos os cercos são maiores e mais desenvolvidos, normalmente apresentando cerdas curtas e grossas na base que progressivamente ficam mais finas. São do mesmo tamanho ou maiores que o tergito $\mathrm{X}$ e normalmente apresentam algum grau de curvatura interna.

A genitália masculina é membranosa e assimétrica, apresentando um esclerito dorsal assimétrico achatado dorsoventralmente (Figuras 1, 17, 36, 46, 56). Associado a ele está o lóbulo dorsal, de formato cilíndrico, por vezes muito maior que os esclerito. A porção apical do lóbulo sinuoso, porção apical do lóbulo basal e projeção bífida são bem esclerotizadas. A membrana basal do esclerito interno é eversível, formando uma estrutura membranosa que acomoda em sua porção apical o apódema basal e o esclerito interno em formato de gancho, fortemente esclerotizado e assimétrico, por vezes ornamentado com espinhos e regiões 
serrilhadas.

Nas fêmeas, o ovipositor é formado pelas gonapófises VIII e XI, côncavas (Figura 2, $7,15,34,44,54)$. As gonapófises IX dispõe de um placa dentada em suas faces internas. A gonoplaca de formato lanceolado ocupa o terceiro quarto da gonapófise IX e tem origem dorsolateral, normalmente apresentando cerdas conspícuas e esparsas em sua ponta. No geral apresentam um variado grau de depressão central, curvando para o interior da cavidade do ovipositor. $\mathrm{O}$ teto do ovipositor, formado pela parte ventral interior dos tergitos IX e $\mathrm{X}$ apresentam duas faixas paralelas de um conjunto de espículas, assim como na gonapófise VIII. As gonapófise VIII são finas e delgadas, repousando em um par sulcos nas margens mais internas das gonapófises VIII. O gonângulo é lanceolado, localizado na base da gonapófise VIII, por vezes apresentando uma característica quilha mediana. As gonapófise VIII e IX, gonângulo e gonoplaca alcançam o paraprocto.

Os ovos possuem placa micropilar localizada próxima a base da cápsula, na face dorsal com uma distinta evaginação da margem (Figuras 9 C; 18 B; 37 B; 47 B; 57 B). A cápsula apresenta um característico engrossamento da parede em padrão geométrico, assim como no opérculo. São desprovidos de capítulo ou pseudocapítulo, e diferentemente dos outros gêneros da tribo não possuem cerdas na cápsula e opérculo (Figuras 9, 18, 37, 47, 57).

\subsection{Chave de Identificação para o Gênero Ceroys}

1. Ambos os sexos com corpos proporcionalmente mais alongados e cabeças retangulares e esguias, terminália mais alongada e achatada. No geral desprovidos de ornamentações, salvo pares de espinhos cônicos e lisos por vezes assimétricos no tórax. Fêmeas apresentam um par de espinhos cônicos e lisos no topo da cabeça e estruturas do ovipositor mais alongadas, com um gonângulo curto e lanceolado curvado dorsalmente. Macho lustroso e liso, com cores vibrantes. Segmento abdominal $\mathrm{X}$ apresentando uma margem posterior dividida medianamente, formando dois lóbulos laterais distintos Canuleius scaber comb. nov.

- Ambos os sexos mais ornamentados e com corpo de aspecto mais rugoso, robusto, apresentando coloração mais críptica e fosca. Terminália compacta e mais alargada. Nas fêmeas o segmento abdominal IX formando uma escama longitudinal ou paralela a margem posterior e normalmente ultrapassando a margem do segmento abdominal X. Machos com terminália sem divisão mediana.

2. Ambos os sexos bem ornamentados com grânulos e espinhos serrilhados ao longo de todo

o corpo e apresentando pernas de aspecto serrilhado. Fêmeas apresentam projeções 
dorsolaterais foliáceas de formato elíptico no tórax, com bordas irregulares e serrilhadas com um espinho mediano. Segmentos abdominais IV e V apresentam lóbulos medianos orientados longitudinalmente. Gonângulo recurvo, cilíndrico, bem desenvolvido. Machos apresentam pequenos espinhos irregulares e levemente assimétricos de margem serrilhada desde a cabeça até o segmento abdominal VI.

Ceroys (Ceroys) cristatus

- . Ambos os sexos apresentando níveis variáveis de grânulos, tubérculos e espinhos. Pernas não apresentam aspecto serrilhado e apresentando níveis variáveis de ornamentação com lóbulos e espinhos recurvos. Fêmeas apresentam um gonângulo lanceolado, por vezes com uma carena mediana.

\section{2}

3 . Ambos os sexos apresentam ornamentações corporais discretas, não possuem projeções laterais no abdômen ou nas conexões dos segmentos abdominais. Pernas lisas apresentando ornamentações lobulares discretas, por vezes ausentes. Pronoto apresenta um par de espinhos na margem posterior. Meso- e metanoto apresentam ao menos um par de espinhos orientados dorsolateralmente, por vezes assimétricos. Fêmea apresenta um par de ornamentações lanceoladas de margem irregular conspícuas próxima ao vértex. Segmento abdominal V e VI apresentam uma ornamentação em formato de escama parelala a margem posterior do segmento correspondente. Segmento abdominal IX se projeta além da margem posterior do segmento abdominal X. Machos lisos, com uma linha mediana preta torácica conspícua e apresentando um pequeno par de espinhos na cabeça.

Ceroys (Ceroys) perfoliatus

- Ambos os sexos apresentando ornamentações mais robustas e bem desenvolvidas ao longo do corpo e pernas. Abdômen apresentando projeções laterais e/ou ornamentações nas conexões dos segmentos abdominais.

4 - Fêmas apresentando ornamentações lobulares arredondadas dorsolaterais com margens irregulares e serrilhadas no meso- e metanoto, com o corpo recoberto de grânulos e espinhos. Machos apresentam espinhos bem desenvolvidos, de bordas irregulares, serrilhadas e curvados próximo ao vértex, além de espinhos lisos dorsolaterais no meso- e metanoto. Ao menos os segmentos abdominais II a IV apresentam um par de espinhos nas margens posteriores.

- Ambos os sexos apresentando um abaulamento ventral do mesonoto, com projeções dorsolaterais triangulares bem desenvolvidas e serrilhadas ao longo do tórax. Corpo recoberto de grânulos e espinhos. Abdômen com ornamentações nas laterais dos segmentos abdominais e suas conexões. Fêmea apresentando um alongamento do tergito $\mathrm{X}$ e da placa subgenital 
formando uma estrutura lanceolada para auxiliar na oviposição. Macho esguio com abdômen apresentando constrições nos segmentos abdominais. ..... Ceroys (Miroceroys) saevissimus

5 - Ornamentações torácicas da fêmea normalmente de formato semi circular. Segmentos abdominais IV-VI e IX apresentando uma crista orientada longitudinalmente. Meta- e mesotíbia apresentando múltiplos lóbulos bem desenvolvidos de formato mais ou menos triangular ao longo de todas as carenas, com uma concentração de ornamentações mais desenvolvidas próxima a porção mediana e posterior. Macho apresenta uma linha longitudinal bege clara muito tênue que se extende do fim do pronoto até a margem posterior do segmento abdominal III, por vezes ausente. Espinhos meso- e metatorácicos triangulares, por vezes assimétricos, levemente recurvados posteriormente. Segmentos abdominais II-III apresentando um par de espinhos na margem posterior. ..... Ceroys (Miroceroys) heymonsi

- Ambos os sexos apresentam meso- e metatíbias menos ornamentadas. Fêmeas possuem projeções torácicas dorsolaterais elípticas, levemente curvadas posteriormente. Segmentos abdominais V, VI e IX apresentam ornamentações em formato de escama paralelas a margem posterior, curvadas e ultrapassando a margem do segmento seguinte. Machos apresentam espinhos dorsolaterais achatados no meso- e metanoto, por vezes assimétricos. Uma linha preta dorsal orientada longitudinalmente se expande da margem anterior do mesonoto até a margem posterior do segmento abdominal VI, sendo mais discreta a partir do segmento III. Segmento abdominal II-IV apresentando um par de espinhos em suas margens posteriores, enquanto o segmento abdominal $\mathrm{V}$ por vezes apresenta um discreta crista mediana na margem posterior, curvada posteriormente.

Ceroys (Miroceroys) sp. nov.

\subsection{Redescrição do Subgênero Ceroys Audinet-Serville, 1838}

Descrição: Como o gênero.

Diagnose: A principal diferença em relação a Miroceroys se dá em relação à ornamentação. Espécies originalmente descritas no subgênero não costumam ser muito ornamentadas, apresentando poucos espinhos, lóbulos e escamas, sendo Ceroys (Ceroys) cristatus a exceção.

Comentários: Como resultado deste trabalho, apenas duas das seis espécies com ocorrência para a Mata Atlântica registradas para o subgênero são consideradas válidas: Ceroys (Ceroys) perfoliatus Audinet-Serville 1838, sendo Ceroys (Ceroys) multispinosum Audinet-Serville, 1838; Ceroys (Ceroys) albogranulatus Piza, 1938 e Ceroys (Ceroys) spinosus Zompro, 2004 seus sinônimo júnior (syn. nov.); e Ceroys (Ceroys) cristatus Redtenbacher, 1906, sendo Ceroys (Miroceroys) brunneri Piza, 1936 seu sinônimo júnior (syn. nov.). Adicionalmente Ceroys (Ceroys) scaber Piza, 1936 é transferida para Canuleius 
Stål, 1875 (comb. nov.).

\subsubsection{Ceroys (Ceroys) perfoliatus (Gray, 1835)}

(Figuras 1 a 10, Tabelas 3 e 4)

Cladomorphus perfoliatus Gray, 1835; Stål 1875.

Acanthoderus perfoliatus Burmeister, 1838; Göldi 1886, Sellick 1980.

Ceroys perfoliatus Audinet-Serville, 1838; Westwood 1859, Kirby 1904, Redtenbacher 1906, Shelford 1909, Giglio-Tos 1910, Piza 1936, Passerin d'Entreves 1981, Vanschuytbroeck \& Cools 1981, Lelong 1993, Sellick 1998, Zompro 2004, Otte \& Brock 2005, Figueiredo de Araujo \& Garraffoni 2012, Brock, Beccaloni \& Harman 2016.

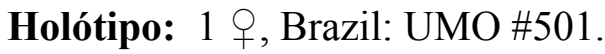

= Ceroys multispinosus Serville, 1838 syn. nov.; Westwood 1859, Kirby 1904.

Mirophasma multispinosum Redtenbacher, 1906; Zompro 2004, Otte \& Brock 2005.

Ceroys (Ceroys) multispinosum Zompro 2004, Conle, Hennemann \& Gutiérrez 2011, Figueiredo de Araujo \& Garraffoni 2012.

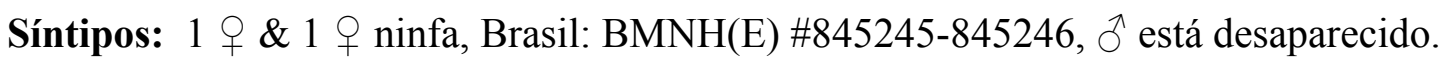

= Ceroys albogranulatus Piza 1938 syn. nov.; Piza 1946; Zompro \& Domenico 2005, Otte \& Brock 2005, Figueiredo de Araujo \& Garraffoni 2012;

Síntipos: $1 \widehat{\jmath}$ (ESALQENT \#00380): Brasil, São Paulo, Paranapiacaba, Alto da Serra.

= Ceroys (Ceroys) spinosus Zompro, 2004; Otte \& Brock 2005, Figueiredo de Araujo \& Garraffoni 2012, Chiquetto-Machado \& Cancello 2021.

Ceroys multispinosus Piza 1936.

Síntipos: 1 (MZUSP \#0010): Brasil, São Paulo, Paranapiacaba, Alto da Serra.

Diagnose. Ambos os sexos apresentam uma ornamentação discreta se comparada aos demais representantes do gênero, com menos tubérculos, áreas serrilhadas e lóbulos nas pernas, tórax e abdômen. Fêmeas de Ceroys (Ceroys) perfoliatus são diferenciadas das demais espécies de Ceroys (Ceroys) pela ausência de ornamentações torácicas de formato lanceolado e dorsoventralmente achatadas, a ausência de ornamentação formada por lóbulos em formato de crista nos tergitos III-VIII (Figuras 3 e 4) e pernas lisas, desprovidas de regiões serrilhadas e espinhos e com ornamentação das tíbias discreta (Figuras 3, 4 e 6). Machos são diferenciados de outras espécies de Ceroys (Ceroys) pela conspícua faixa medianodorsal no tórax e primeiros segmentos abdominais, pelos espinhos mesotorácicos dorsolaterais mais lisos e menos robustos, muitas vezes assimétricos (Figuras 3, 4, 6), o abdômen com marcas de constrição menos evidentes, a ausência de tubérculos, espinhos e 
estruturas serrilhadas nas pernas, a ausência de espinhos nas margens posteriores dos tergitos abdominais e o tamanho comparativamente menor.

\section{Redescrição da fêmea (Figuras 3-7, 10)}

Bicho-pau de médio porte, distintamente mais robusta que o macho. Corpo rugoso, apresentando lóbulos, tubperculos e espinhos discretos.

Coloração (Figuras 3-7, 10). Corpo normalmente varia entre tons de marrom escuro a verde rajado de cinza e bege, normalmente em tons mais escuros que os machos. Meta- e mesotórax e segmento mediano apresentando linha mediana escurecida. Palpos e mandíbulas amarelo escuro. Olhos amarelados cobertos por manchas irregulares escurecidas, por vezes apresentando uma suave faixa mediana mais escura. Cabeça, corpo e pernas normalmente apresentando um padrão semi homogêneo de cor, normalmente mais claro na porção dorsal do tórax e abdômen e escuro ventralmente. Pernas são normalmente rajadas ou manchadas em tons mais escuros de marrom, incluindo os tarsômeros, com a porção anterior do promeso e metafêmur normalmente bege esverdeados. Tubérculos e espinhos normalmente apresentam a mesma cor do restante do corpo.

Cabeça (Figuras 3-5). Levemente alongada e levemente rugosa, mas de aparência arredondada por conta da ornamentação presente no vértex. Sub retangular em vista lateral e elíptica dorsalmente, cerca de 1.5x mais longa que larga e cerca de $1.3 \mathrm{x}$ mais longa que o pronoto. Vértex convexo, apresentando um par de espinhos lanceolados e irregulares lateralmente orientados de aparência rugosa, tuberculados, com margens irregulares e ápice terminando em uma ponta aguda (Figura 5). Antena com cerca de vinte e dois a vinte e cinco antenômeros; apresentando pequenas cerdas por toda sua extensão, porém concentradas principalmente nas nos vértices, alcançando o segmento abdominal IV-V quando estendidas posteriormente. Órgão antenal conspícuo, amarelado, largo, presente na margem dorsal posterior do décimo quarto antenômero.

Tórax (Figuras 3, 4, 6, 10). Protórax subquadrado em seção transversal, meso- e metatórax sub cilíndricos. Pronoto tuberculado, rugoso, com sulcos profundos, subretangular em vista dorsal, levemente elevado posteriormente, cerca de 1.1x mais longo do que largo, por vezes apresentando dorsalmente um par de espinhos medianos pequenos posicionados logo antes da sutura mediana, além de um par de espinhos maiores posteriores. Mesotórax rugoso, levemente tuberculado, cerca de $3,4 \mathrm{x}$ maior que o protórax, apresentando dorsalmente alguns espinhos paramedianos assimétricos. Ao menos um par localizado medianamente disposto lateralmente (Figuras 3, 4 e 11). Metatórax e segmento mediano rugosos, tuberculados (Figura 6); metatórax, cerca de 2.4x mais longos que o segmento 
mediano; mesotórax cerca de 1.42x mais longo que o metatórax e o segmento mediano combinados. Metatórax rugoso, por vezes apresentando pequenos e discretos tubérculos, apresentando uma leve sutura na divisão entre o metatórax e o segmento mediano. Meso- and metaepimero projetando-se além dos respectivos segmentos, mesoepimero curto; coxopleurito irregular, tuberculado; meso- e metaepisterno projetados lateralmente como um lóbulo irregular de margens arredondadas (Figura 6).

Pernas (Figuras 3, 4, 6, 10). Os fêmures são carenados e pouco tuberculados, por vezes lisos. Meso- e metafêmur apresentando lóbulos rugosos discretos de variados tamanhos tanto nas carenas dorsais quando ventrolaterais. Tibia com carenas pouco proeminentes e pouco tuberculadas.

Abdômen (Figuras 2, 3, 4, 7). Como no gênero. Segmentos II-VII com uma constrição central suave, quase imperceptível em fêmeas maduras ou gestantes. Tergito $\mathrm{V}$ e VI apresentam um escama lobada mediana. Dependendo do indivíduo, a escama V pode ser maior que a VI ou vice versa, mas nunca de tamanhos iguais. A maior escama é larga, bem desenvolvida, inclinada no sentido posterior do abdômen e ultrapassando a margem anterior do segmento abdominal seguinte, enquanto a menor é fina, por vezes parecendo um espinho achatado, raramente ultrapassando a margem posterior do segmento abdominal seguinte. Tergito $\mathrm{X}$ irregular, quilhado, rugoso, com sua margem posterior alargada e lobada de forma irregular (Figura 7). Placa subgenital elíptica, com margem posterior arredondada (Figura 7), por vezes ultrapassando levemente a margem do tergito $\mathrm{X}$; apresentando um quilha nos dois terços da porção anterior, tuberculada de forma mais intensa a partir de sua porção mediana. Orgão pré opercular distintamente proeminente, escurecido, rugoso, de formato triangular bem definido com uma quilha mediana proeminente (Figura 7).

Redescrição do macho (Figuras 1, 4-6, 8, 9, 10)

Bicho-pau áptero, fino e espinhoso, normalmente em tons de marrom e preto, com característica linha dorsal mediana escurecida.

Coloração (Figuras 4-6, 8, 9, 10). O corpo varia em tons de bege escuro e marrom acastanhado, normalmente em tons mais claros que as fêmeas. Meta- e mesotórax, junto com o segmento mediano e tergitos II e III apresentam uma conspícua linha preta longitudinal e uma faixa preta lateral. A cabeça apresenta diferentes tons de marrom claro, escuro e bege, com uma linha longitudinal lateral percorrendo da margem posterior da cabeça até atrás dos olhos. Os olhos compostos são amarelados em indivíduos vivos, alaranjados em material fixado a seco. As antenas são marrom claro dorsalmente, escurecidas ventralmente. Pernas normalmente são em tons mais escuros de marrom, geralmente uniforme incluindo os 
tarsômeros. Tubérculos e espinhos da mesma cor que a região do corpo que se encontram e seguindo o padrão de coloração do corpo, mais claros dorsalmente e escurecidos ventralmente.

Cabeça (Figuras 4 e 5). Levemente alongada e tuberculada. Ovóide em vista dorsal, cerca de 1.1x mais longa que larga, com cerca do mesmo comprimento do pronoto. Vertex gentilmente convexo com um par de espinhos medianos, orientados sutilmente para os lados, cônicos. Antena chegando ao segmento abdominal $\mathrm{X}$ quando estendida posteriormente. Órgão antenal conspícuo, levemente menor que o da fêmea, presente na margem posterior dorsal do décimo terceiro antenômero.

Tórax (Figuras 4-5). Protórax subquadrado em seção transversal, meso- e metatórax subcilíndricos. Pronoto tuberculado, com sulcos profundos, sub-retangular em vista dorsal, em formato de sela, posteriormente elevado, cerca de $1.1 \mathrm{X}$ mais longo do que largo. Apresenta dorsalmente um par de pequenos espinhos cônicos medianos logo antes da sutura mediana e ou outro par de espinhos maiores e mais robustos na margem posterior. Mesotórax liso, cerca de 3,9x mais longo do que o protórax, discretamente tuberculado lateralmente e apresentando ao menos um par de espinhos assimétricos orientados lateralmente. Metatórax e segmento mediano lisos, tuberculados como no metatórax (Figura 5); metatórax cerca de 3x mais longo que o segmento mediano, mesotórax cerca de $1.3 \mathrm{x}$ mais longo que o metatórax e segmento medianos combinados. Metatórax apresentando uma discreta sutura na divisão entre o metatórax e o segmento mediano. Meso- e metaepímero se projetando além de seus respectivos segmentos, mesoepímero curto; coxopleurito irregular, tuberculado; meso- e metaepisterno projetados lateralmente como lóbulos irregulares de margens arredondadas.

Pernas (Figuras 4-5 e 11). Fêmures apresentam todas as carenas levemente quilhadas, tuberculadas e lisas. Meso- e metafêmur desprovidos de ornamentações como nas fêmeas. Tíbia com leve carenas tuberculadas. Basitarsos com cerca do mesmo tamanho de todos os outros tarsômeros combinados.

Abdômen (Figuras 4 e 8). Como no gênero, liso, levemente rugoso até sua metade posterior. Segmentos II-VII mais longos que largos, VIII-IX mais largos que longos, X tão longo quanto largo. Segmentos gradualmente diminuindo de tamanho entre os segmentos VI a IX. Segmentos II-VIII com uma constrição central, gradualmente se intensificando nos segmentos mais posteriores. Tergito VIII alargado consideravelmente em sua porção posterior. Tergitos VIII-X com uma carena contínua conspícua central e duas paramedianas. Tergitos VII-IX com uma margem posterior elevada e arredondada. Tergito X cerca de $1.3 \mathrm{x}$ mais longo que o IX; com margem posterior distintamente emarginada (Figura 8), formando dois lóbulos laterais, cada qual apresentando uma placa dentada com pequenos espinhos 
curtos, robustos e curvos separados por uma quilha mediana (Figura 8). Esternito VIII mais curto que o tergito correspondente, mais largo que longo e apresentando posteriormente duas quilhas projetadas paramedianamente. Esternito IX formando um póculo de formato distinto, côncavo, similar a uma xícara (Figura 8); região ventral com uma carena mediana conspícua se estendendo à uma confluência posterior aguda, com margem fortemente esclerotizada. Paraprocto curto, curvado internamente, normalmente oculto pelos cercos. Epiprocto quilhado, largo e triangular. Cercos cilíndricos, apresentando um discreto afunilamento apical e um achatamento dorsoventral a partir da sua porção mediana (Figura 8).

Genitália (Figura 1): Esclerito dorsal tendo origem do lado direito da estrutura da genitália quando em vista dorsal. Tem formato irregular, com a margem posterior terminando diagonalmente oposta a sua origem e apresentando um prolongamento em sua margem orientado ventralmente, onde o lóbulo dorsal está associado. O lóbulo dorsal membranoso, largo. A membrana basal do esclerito interno é cilíndrica, normalmente envolvendo o esclerito interno dentro da estrutura da genitália, oculta pelo lóbulo dorsal, o lóbulo sinuoso ventral e o lóbulo basal. A porção apical do lóbulo sinuoso, porção apical do lóbulo basal e projeção bífida são bem esclerotizadas. A projeção bífida está localizada do lado direito da genitália quando observada frontalmente. A membrana basal do esclerito interno é eversível, formando uma estrutura membranosa cilíndrica que acomoda em sua porção apical o apódema basal, discreto e em formato de escama, e o esclerito interno em formato de gancho, fortemente esclerotizado e assimétrico, curvado para a esquerda. A ponta do esclerito interno é arredondada, e possui ao longo de toda sua extensão espinhos robustos que conferem a ele um aspecto serrilhado.

\section{Descrição dos ovos (Figura 9)}

De coloração amarronzada, alternando entre um bege dourado a marrom escuro. Com formato de barril, distintamente côncavos dorsalmente, cerca de 1.6x mais longos do que largos. A superfície apresenta cristas reticuladas distintas, robustas e grossas, com disposição circular na margem opercular. Os pontos de encontro das cristas resultam em pequenas projeções que se elevam além de sua altura regular, culminando em projeções arredondadas tanto na cápsula do ovo quanto no opérculo. As cristas formam no geral padrões geométricos pentagonais de formatos variados, circundando aberturas levemente côncavas, brilhantes, de tamanho variado, normalmente arredondadas ou elípticas. O opérculo é circular, com superfície similar ao resto da cápsula do ovo, apresentando as mesmas cristas e aberturas porém apresentando uma única abertura central. A micrópila com uma linha mediana distinta, se estendendo da margem posterior da placa micropilar até sua base, percorrendo cerca de $2 / 5$ 
do seu comprimento. A placa micropilar externa é distinta, depressa, arredondada, com superfície brilhante e rugosa, com uma leve elevação enrugada do poro micropilar no meio da placa. O poro micropilar é escurecido e anteriormente convexo. Linha mediana contínua com as margens da placa micropilar, elevadas, formando um margem lisa, contínua, quase indistinta do restante da placa micropilar, mais fina e clara que as cristas da cápsula do ovo, porém externamente conectadas.

Distribuição. Ceroys (Ceroys) perfoliatus ocorre em toda a região Norte e central da Serra do Mar, sendo encontrado desde a cidade do Rio de Janeiro até a região de Paranapiacaba no município de Santo André, São Paulo, Brasil. Ocorre em altitudes mais baixas, em regiões de florestas ombrófilas e estacional semidecidual no domínio de Mata Atlântica. É possível que a distribuição da espécie seja mais ampla, ocorrendo por toda a extensão da Serra do Mar.

Comentários: Material tipo de Ceroys (Ceroys) albogranulatus e Ceroys (Ceroys) spinosus foram analisados pessoalmente nas coleções onde se encontram depositados, enquanto os holótipos de Ceroys (Ceroys) multispinosum e Ceroys (Ceroys) perfoliatus foram analisadas através de fotos disponíveis no PSF. No último caso, apesar da impossibilidade de análise física do material e em especial o mau estado de conservação de Ceroys (ceroys) multispinosum características diagnósticas da espécie como as escamas abdominais dorsais do segmentos abdominais V e VI, a padronagem e disposição dos espinhos torácicos e anatomia externa das estruturas do ovipositor da fêmea estavam bem conservadas e ilustradas nos registros, permitindo a correlação do material com os espécimes depositados em coleções nacionais.

\section{Material Complementar Analisado}

19 (MZSP \#0011): Rio de Janeiro, Corcovado. 20.VI.1940; 19 (MZSP \#0012) e ovos: Rio de Janeiro; 19 (MZSP \#0021) e $2 \hat{\jmath}($ MZSP \#0026, \#0027): Rio de Janeiro.; $1 q$ (MZSP \#0016): São Paulo, Paranapiacaba. 16.IX.1956. Werner col.; 19 (MZSP \#0117): Brasil, Rio de Janeiro, Parati. 19.XII.1985. A. Mesa e F. Mello col.; 1 q(MZSP \#0624) e $2 \overbrace{}^{\lambda}$ (MZSP \#0532, \#0533, \#0562): Brasil, Rio de Janeiro, Parque Nacional da Serra dos Órgãos, Núcleo Teresópolis. 22²7'14”S, 4259’32”W. 5-6.XII.2015. P. I Chiquetto-Machado e A. Z. Ramin col.; $1 \delta^{\Uparrow}$ (MZSP \#0130): São Paulo, Paranapiacaba. 29.XII.1959.; 4ㅇ (MZSP \#0110, \#0120, \#0121, \#0122): Brasil, São Paulo, Ubatuba. 18.XII.1985. A. Mesa e F. Mello col.; $1 q$ (MZSP \#0112) e 1 $\sigma^{\Uparrow}$ (MZSP \#0129): Brasil, São Paulo, Boracéia. 9-12.V.1974. A. Mesa col.; $3 ð$ (MZSP \#0126, \#0127): Brasil, São Paulo, Boracéia. 22.III.1989. A. Mesa col.; 7 \% 
(MZSP \#0113, \#0114, \#0115, \#0116, \#0118, \#0119, \#0125), 6へ (MZSP \#0128, \#0133, \#0134, \#0135, \#0136, \#0137): Brasil, São Paulo, Boracéia. 14-20.IV.1984. A. Mesa, D. Cella, F. Mello, C. Fontanetti e J. Ramos col.; $1 \widehat{o}$ (MZUSP \#0540): Brasil, São Paulo, Bertioga. 234'37’'S, 4555'44”W. 7.XI.2015. P. W. Engelking e E. W. Engelking col.; 6 ㅇ (MZUSP \#0596, \#0597, \#0598, \#0613, \#0625, \#0626), 6ð (MZUSP \#0592, \#0593, \#0594, \#0595, \#0612, \#0627) e ovos: Brasil, São Paulo, Salezópolis, Estação Biológica de Boracéia.

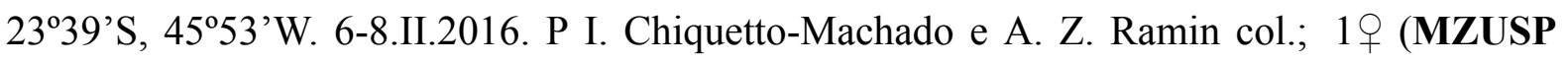
\#1174): Brasil, São Paulo, Santo André, Paranapiacaba. 2347’03.2”S, 46¹8'08.3”W. em samambaia, Verão de 2016. V. M. Ghirotto e P. W. Engelking col.; 1 + (MZUSP \#1173): Brasil, São Paulo, Caraguatatuba, baixada. 2338'18.5”S, 45²6'55.1”W. em samambaia,

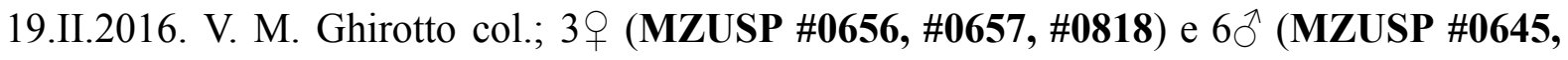
\#0646, \#0647, \#0655): Brasil, São Paulo, Salesópolis, Estação Biológica de Boracéia.

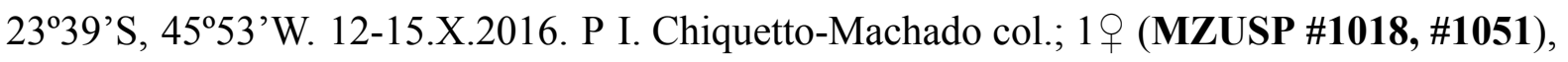
3ð (MZUSP \#1019, \#1020, \#1021): Brasil, São Paulo, Bertioga, Riviera de São Lourenço. 234'ㄴ'’S, 4601'21’'W. 11.XI.2018. P. A. Neves col.

\subsubsection{Ceroys (Ceroys) cristatus Redtenbacher 1906}

(Figuras 11 a 21, Tabelas 5 e 6 )

Ceroys cristatus Redtenbacher 1906; Brock. 1998; Zompro. 2004; Otte \& Brock. 2005; Figueiredo de Araujo \& Garraffoni. 2012.

>>Síntipos: $\uparrow$ e $\overparen{\jmath}$ Brazilien, "Mus. Berlin"

= Ceroys (Miroceroys) brunneri Piza, 1936 syn. nov.; Zompro. 2004; Zompro \& Domenico. 2005; Otte \& Brock. 2005; Figueiredo de Araujo \& Garraffoni. 2012.

Ceroys brunneri Piza. 1936, Piza. 1946.

>>Holótipo 19 (MZUSP \#0006): Rio de Janeiro, Serra de Macahé.

Diagnose. Ambos os sexos apresentam uma elevação considerável na quantidade e grau de desenvolvimento de tubérculos, espinhos corporais, regiões serrilhadas e lóbulos nas pernas, tórax e abdômen se comparados a Ceroys (Ceroys) perfoliatus. Fêmeas de Ceroys (Ceroys) cristatus são diferenciadas das demais espécies de Ceroys (Ceroys) pela presença de crista nos tergitos III-VIII (Figuras 11-12, 15, 19) e corpo densamente granulado (Figuras 11-15, 19), além de apresentarem os espinhos torácicos alargados lateralmente (especialmente em sua base) e achatados dorsoventralmente, conferindo-os uma distinto semblante triangular, quase lanceolado. Machos são diferenciados de outras espécies de Ceroys (Ceroys) 
pelos espinhos mesotorácicos dorsolaterais irregulares, pareados, em maior quantidade, robustos e ramificados (Figuras 12, 14); o abdômen com marcas de constrição mais evidentes, a presença de espinhos nas margens posteriores de quase todos os tergitos abdominais e vértices das pernas serrilhados.

\section{Redescrição da fêmea (Figuras 11-15, 19)}

Bicho-pau de médio porte, distintamente mais robusta que o macho. Corpo ornamentado com lóbulos, projeções foliáceas, tubérculos e espinhos, com ornamentação característica em crista no abdômen.

Coloração (Figuras 11-15, 19). O corpo varia entre tons claros e escuros de verde, bege e marrom, normalmente em tons mais escuros que os machos. Meta- e mesotórax e segmento mediano apresentando linha mediana esbranquiçada, emoldurada por duas linhas pretas. Palpos e mandíbulas amarelo escuro. Olhos amarelados cobertos por manchas irregulares escurecidas. Cabeça apresentando os mesmos tons de coloração do corpo e apresentando manchas mais claras e escuras de pigmentação distribuídas de forma irregular, além de uma linha longitudinal lateral percorrendo da margem posterior até atrás dos olhos. Pernas são normalmente rajadas ou manchadas em tons mais escuros da cor do corpo, incluindo os tarsômeros, com a porção anterior do pro- meso e metafêmur normalmente bege esverdeados. Tubérculos, espinhos e projeções foliáceas normalmente apresentam pontas mais claras, normalmente em tons de bege e laranja. O abdômen costuma apresentar um par de manchas claras na lateral do tergito VII, e por vezes em indivíduos de tonalidade mais clara a porção final do abdômen apresenta mais manchas escuras em tons de marrom.

Cabeça (Figuras 11-13, 19). Levemente alongada e distintamente tuberculada. Subretangular em vista lateral e elíptica dorsalmente, cerca de 1.5x mais longa que larga e cerca de 1.3x mais longa que o pronoto. Vértex convexo, apresentando um par de espinhos similar ao apresentado por fêmeas de Ceroys (Ceroys) perfoliatus, porém com margens com projeções ainda mais irregulares (Figuras 13 e 19). Olhos compostos relativamente pequenos, redondos, projetando-se lateralmente e levemente orientados anteriormente. Palpos labiais e maxilares robustos, com segmentos terminais ovalados e arredondados (Figura 13). Antenas alcançando o segmento abdominal IV-V quando estendidas posteriormente. Escapo podendo apresentar uma discreta ornamentação na margem anterior externa; pedicelo sub cilíndrico, com mais da metade do tamanho de comprimento do escapo. Órgão antenal conspícuo, amarelado, largo, presente na margem dorsal posterior do décimo segundo antenômero.

Tórax (Figuras 11-12, 14, 19). Protórax subquadrado em seção transversal, meso- e metatórax sub-cilíndricos. Pronoto densamente tuberculado, rugoso, com sulcos profundos, 
sub-retangular em vista dorsal, levemente elevado posteriormente, cerca de 1.1x mais longo do que largo, apresentando os mesmos espinhos que Ceroys (Ceroys) perfoliatus, porém mais tuberculados e podendo apresentar ao menos um par extra lateralmente na porção posterior. Mesotórax rugoso, tuberculado, cerca de 3,4x maior que o protórax, apresentando dorsalmente alguns espinhos paramedianos assimétricos. Ao menos um par localizado próximo a margem posterior, e um par de ornamentações foliáceas e lanceoladas, irregulares, rugosas, tuberculadas e achatadas dorsoventralmente dispostas lateralmente, posteriormente orientadas de forma sutil e com ápice terminando em uma ponta aguda (Figuras 11-12, 14 e 19), além de dois pares menores de espinhos cônicos dispostos anteriormente e posteriormente. Metatórax e segmento mediano rugosos, tuberculados (Figura 15); metatórax, cerca de 2.4x mais longos que o segmento mediano; mesotórax cerca de 1.4x mais longo que o metatórax e o segmento mediano combinados. Metatórax apresentando centralmente um par de ornamentações similares às presentes no mesotórax, apresentando um par de espinhos cônicos na divisão entre o metatórax e o segmento mediano. Meso- e metaepímero projetando-se além dos respectivos segmentos, mesoepímero curto; coxopleurito irregular, tuberculado; meso- e metaepisterno projetados lateralmente como um lóbulo irregular com um espinho apical (Figura 14).

Pernas (Figuras 11-12, 14 e 19). Pernas posteriores ultrapassando o final do segmento abdominal X quando estendidas posteriormente. Fêmures carenados e tuberculados, apresentando espinhos cônicos e projeções foliáceas e fracamente tuberculados na carena ventral. Meso- e metafêmur apresentando lóbulos rugosos distintos de variados tamanhos tanto nas carenas dorsais quando ventrolaterais. Tíbias com com carenas pouco proeminentes, bem tuberculadas e apresentando pequenas cristas seriadas nas carenas dorsais, especialmente na protíbia..

Abdômen (Figuras 11, 12, 15, 19). Segmentos II-VII com uma constrição central suave. Tergitos II e III apresentando um par de espinhos bem desenvolvidos em sua margem posterior. Tergitos abdominais III a V apresentam cristas medianas, sendo a presente no segmento III a menor e menos conspícua e a $\mathrm{V}$ maior e mais robusta, orientadas medianoposteriormente e normalmente se projetando além da margem anterior do segmento abdominal seguinte. Cristas normalmente apresentando bordas irregulares e armadas. Tergito VIII e IX apresentam escamas similares às presentes em Ceroys (Ceroys) perfoliatus, porém de origem mediana posterior e de aspecto similar às cristas dos tergitos abdominais III-V. Tergito $\mathrm{X}$ irregular, quilhado, rugoso, com sua margem posterior alargada e lobada de forma irregular (Figura 15). Placa subgenital elíptica, com margem levemente lanceolada (Figura 15), normalmente não ultrapassando as margens do tergito abdominal $X$; apresentando um 
quilha nos dois terços da porção anterior, tuberculada de forma mais intensa a partir de sua porção mediana. Orgão pré opercular distintamente proeminente, escurecido, rugoso, de formato globoso e liso, sendo delimitado anteriormente por duas quilhas paralelas mediano laterais e com projeções laterais discretas e arrendondadas nas margens posteriores do esternito VII (Figura 15). Gonângulo cilíndrico e proeminente, normalmente alcançando a base da gonoplaca e apresentando um número crescente de cerdas nas porções mais apicais (Figura 15).

\section{Redescrição do macho (Figuras 12-14, 16-17, 20)}

Bicho-pau áptero, esguio e densamente tuberculado, com pernas de aparência serrilhada e apresentando múltiplos pares de espinhos ao longo do tórax e segmentos abdominais.

Coloração (Figuras 12-14, 16-17, 20). O corpo varia em tons de bege, marrom ou verde, normalmente em tons mais claros que as fêmeas, e podendo apresentar uma combinação de todas as cores em um único indivíduo em um padrão rajado. Meta- e mesotórax, junto com o segmento mediano e tergitos II e III apresentam uma inconspícua linha preta longitudinal, similar a observada nas fêmeas. Cabeça apresentando a mesma padronagem de cor do corpo com uma linha lateral percorrendo da margem posterior da cabeça até atrás dos olhos. Olhos amarelados. Antenas marrom claro dorsalmente, escurecidas ventralmente. Pernas normalmente são rajadas ou manchadas em tons mais escuros de marrom, incluindo os tarsômeros, com a porção anterior do pro-, meso- e metafêmur esverdeados como nas fêmeas. Tubérculos e espinhos por vezes em tons mais escuros do que o apresentado no corpo. Ornamentações torácicas lobadas seguem o padrão de coloração do corpo, mais claras dorsalmente e escurecidas ventralmente.

Cabeça (Figuras 12-13, 20). Levemente alongada e tuberculada, ovóide em vista dorsal, cerca de 1.1x mais longa que larga, com cerca do mesmo comprimento do pronoto. Vertex gentilmente convexo com um par de espinhos lateralmente orientados, por vezes orientados para tráz, tuberculados e com projeções irregulares. Antenas filiformes chegando ao segmento abdominal $\mathrm{X}$ quando estendida posteriormente. Escapo liso; pedicelo sub cilíndrico, com mais da metade do tamanho do escapo. Órgão antenal conspícuo, levemente menor que o da fêmea, presente na margem posterior dorsal do décimo terceiro antenômero.

Tórax (Figuras 12-14, 20). Protórax subquadrado em seção transversal, meso- e metatórax sub-cilíndrico. Pronoto tuberculado, com sulcos profundos, sub-retangular em vista dorsal, em formato de sela e com uma sutura mediana fortemente marcada, posteriormente elevado, cerca de 1.1 mais longo do que largo. A ornamentação do pronoto é similar à vista 
em machos de Ceroys (Ceroys) perfoliatus. Mesotórax liso, cerca de 3,9x mais longo do que o protórax, tuberculado ventral, lateral e dorsalmente e apresentando ao menos um par de espinhos assimétricos próximos à margem anterior do mesotergito, um par simétrico na margem posterior e um par de espinhos cônicos, dorso-ventralmente achatados e lateralmente orientados em sua porção mediana em direção ao abdômen. Metatórax e segmento mediano tuberculados como no metatórax (Figura 14); metatórax cerca de 3x mais longo que o segmento mediano, mesotórax cerca de $1.3 \mathrm{x}$ mais longo que o metatórax e segmento medianos combinados. Metatórax apresentando em sua porção central um par de espinhos cônicos achatados dorsoventralmente e lateralmente orientados como no mesotórax, além de um par de espinhos cônicos menores e bem desenvolvidos na divisão entre o metatórax e o segmento mediano. Meso- e metaepímero se projetando além de seus respectivos segmentos, mesoepímero curto; coxopleurito irregular, tuberculado; meso- e metaepisterno projetados lateralmente como lóbulos irregulares, com espinhos apicais conferindo uma aparência serrilhada.

Pernas (Figuras 12-14, 20). Fêmures apresentam todas as carenas levemente quilhadas, tuberculadas e apresentando projeções em formato de lóbulos ou espinhos cônicos. Meso- e metafêmur apresentando ornamentações como nas fêmeas, porém de forma mais discreta e irregular. Tíbia com carenas discretas, tuberculadas e apresentando pequenas cristas na carena dorsal externa. Basitarsos com cerca do mesmo tamanho de todos os outros tarsômeros combinados.

Abdômen (Figuras 12 a 14, 16 a 17). Distintamente tuberculado. Segmentos II-VII mais longos que largos, VIII-IX mais largos que longos, X tão longo quanto largo. Segmentos gradualmente diminuindo de tamanho entre os segmentos VI a IX. Segmentos II-VIII com uma constrição central, gradualmente se intensificando nos segmentos mais posteriores. Tergitos II-VII apresentam um par de espinhos próximos à margem posterior; tergito VIII alargado consideravelmente em sua porção posterior. Tergitos VIII-X com uma carena contínua conspícua central e duas paramedianas. Tergitos VII-IX com uma margem posterior elevada e arredondada. Tergito X cerca de 1.3x mais longo que o IX; Com margem posterior distintamente emarginada (Figura 16), formando dois lóbulos laterais, cada qual apresentando uma placa dentada com pequenos espinhos curtos, robustos e curvos (Figura 16). Esternito VIII mais curto que o tergito correspondente, mais largo que longo e apresentando posteriormente duas quilhas projetadas para medianamente. Esternito IX formando um póculo de formato distinto, côncavo, similar a uma xícara (Figura 16); região ventral com uma carena mediana conspícua se estendendo à uma confluência posterior aguda, com margem fortemente esclerotizada. Paraprocto curto, curvado internamente, oculto pelos 
cercos epiprocto quilhado, largo e triangular. Cercos distintamente achatados dorsoventralmente por toda sua extensão (Figura 16).

Genitália (Figura 17): Similar a de Ceroys (Ceroys) perfoliatus, porém com todas as estruturas orientadas no sentido contrário. Esclerito dorsal sem apresentar um prolongamento em sua margem orientado ventralmente, lóbulo dorsal está associado diretamente da margem superior do esclerito dorsal. O lóbulo dorsal é membranoso, largo, longo e peduncular. Demais estruturas como em Ceroys (Ceroys) perfoliatus, com exceção do esclerito interno em formato de gancho, fortemente esclerotizado e assimétrico, curvado para a direita e proporcionalmente mais longo. A ponta do esclerito interno é aguda e bem pronunciada, sendo desprovido ao longo de toda sua extensão de qualquer forma de ornamentação.

\section{Descrição dos ovos (Figura 18)}

De coloração amarronzada, podendo variar entre tons mais claros e escuros. Com formato de barril, levemente côncavos dorsalmente, cerca de 1.6x mais longos do que largos. Apresentando uma estruturação da cápsula e cristas similar a Ceroys (Ceroys) perfoliatus, com exceção de que o padrão geométrico formado tende a formatos hexagonais e as aberturas formadas pelas cristas são proporcionalmente maiores. Além disso, as cristas do opérculo se conectam medianamente, formando múltiplas aberturas na lateral do opérculo ao contrário da única abertura opercular em Ceroys (Ceroys) perfoliatus. Micrópila com uma linha mediana distinta, se estendendo da margem posterior da placa micropilar até sua base, percorrendo cerca de 2/5 do seu comprimento. Placa micropilar externa distinta, depressa, arredondada, com superfície brilhante e rugosa, com uma leve elevação enrugada do poro micropilar no meio da placa. Poro micropilar escurecido, anteriormente convexo. Linha mediana contínua com as margens da placa micropilar, elevadas formando um margem rugosa e irregular, mais fina e clara que as cristas da cápsula do ovo, porém externamente conectadas. A linha mediana e cristas da cápsula formam uma estrutura similar a três quilhas basais.

Distribuição. Ceroys (Ceroys) cristatus é conhecido para a região do Estado do Rio de Janeiro, especialmente na região da Serra da Mantiqueira, e na Serra da Bocaina, no Estado de São Paulo.

Comentários: Material tipo de Ceroys (Ceroys) cristatus foi analisado através de fotos disponíveis no PSF. Apesar da impossibilidade de análise física do material, ambos os espécimes estão em relativo bom estado de conservação e características diagnósticas da espécie, incluindo padrões de ornamentação em ambos os sexos e morfologia das estruturas 
do ovipositor da fêmea, estavam bem conservadas e ilustradas nos registros permitindo a correlação do material com os espécimes depositados em coleções nacionais. O material tipo é acompanhado também de ilustrações que acompanham a descrição original, auxiliando na identificação da espécie. Esta é a única espécie dentro do gênero Ceroys que apresenta uma morfologia diferente da anatomia externa das estruturas do ovipositor, em especial na anatomia do gonângulo. As implicações dessas características são discutidas adiante na seção de discussão.

\section{Material complementar analisado}

19 (MELQ \#499) and 1ð (MELQ \#494) Mury, Nova Friburgo, Rio de Janeiro, Brasil. 18-21.II.1963. Gred \& Guimarães col.; $1 \delta^{\Uparrow}$ (MELQ \#493) Itatiaia, Rio de Janeiro. 900m. II.1944. H. Zellibor col; 19 (MZUSP \#0018): Itatiaia, V.1950. Lima Macieira col.; 1 q (MZUSP \#0106): Brasil, Rio de Janeiro, Parque Nacional do Itatiaia, Picada do Vèu da Noiva. 10.X.1995. 1100m de altitude. A. Mesa, E. Zefa, L. de Souze e C. Sperber col.; 1 q (MZUSP \#0107): Brasil, Itatiaia, Rio de Janeiro, 1.100 m. Diring col.; 1 + (MZUSP \#0733,

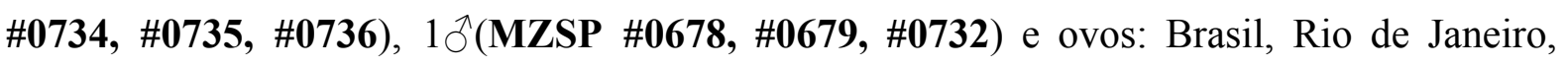
Parque Nacional do Itatiaia, parte baixa. $22^{\circ} 25^{\prime} 35^{\prime}$ 'S, $44^{\circ} 37^{\prime} 05^{\prime \prime}$ W. 31.X-2.XI.2016. P.I. Chiquetto-Machado col; 19 (MZUSP \#0748), $1 \sigma^{\Uparrow}$ (MZUSP \#0747, \#0838) e ovos: Brasil, Rio de Janeiro, Santa Maria Madalena, Parque Estadual do Desengano, Trilha do Poço do Padre. 2152'30”S, 4155’24’W. 26.XI.2016. P. I Chiquetto-Machado, J. P. Constantini, N. C. C. P. Barbosa col.; 19 (MZUSP \#1030): Brasil, Rio de Janeiro, Itatiaia, Maromba.

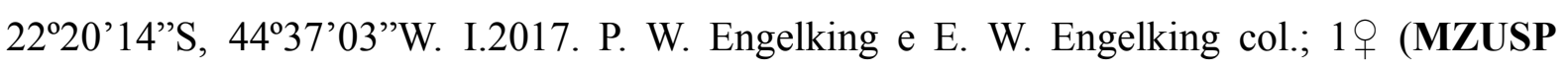
\#1135): Brasil, Rio de Janeiro, Itatiaia. I.1967; 1 ( (MZUSP \#0861): Brasil, São Paulo, São José do Barreiro, Parque Nacional da Serra da Bocaina. Estrada. 2244'17’S, 44³6'59'W. Coleta noturna ativa. 10.IV.2017. H. M. Rodrigues col.; 19 (MZUSP \#1226) Brasil, São Paulo, Parque Nacional da Serra da Bocaina, Portaria próxima a casa dos vigias. $22^{\circ} 44^{\prime} \mathrm{S}$, 44³7’W. 22.III.2019. I. M. Cunha col.

\subsection{3 - Canuleius scaber (Piza, 1936) comb. nov.}

(Figuras 22 a 30, Tabela 7)

Ceroys scaber Piza 1936. Piza. 1946.

Ceroys (Ceroys) scaber Zompro. 2004. Zompro \& Domenico. 2005. Otte \& Brock. 2005.

Figueiredo de Araujo \& Garraffoni. 2012.

Holótipo $q$ (MZUSP \#0014): Brasil, São Paulo, Paranapiacaba, Alto da Serra. 
Redescrição da Fêmea (Figuras 22-26, 30):

Bicho pau delgado, de tamanho mediano; maior e mais encorpada do que o macho.

Coloração (Figuras 22-26, 30): Coloração críptica, diferentemente dos tons mais chamativos do macho. Corpo variando entre tons de verde, marrom e bege e normalmente apresentando ventralmente coloração mais clara que no dorso, incluindo a placa subgenital. Peças bucais alaranjadas. Olhos amarelados com uma faixa horizontal preta cruzando todo o seu diâmetro em sua porção mediana. Porção posterior das pernas, em especial pro-, meso- e metafêmur, bege apresentando um padrão rajado ou manchado de preto. Espinhos apresentando cores similares às do corpo, enquanto a porção basal do pro-, meso- e metafêmur verde claro azulado.

Cabeça (Figuras 22-24, 30): Alongada, recoberta por espinhos e tubérculos principalmente na face dorsal em sua porção posterior, dos quais ao menos um par é bem conspícuo localizado sob o vértex. Em vista dorsal sub-retangular, com o comprimento praticamente igual ao de sua largura e ao comprimento do pronoto. Vértex chato. Olhos compostos pequenos, quase um quarto do comprimento da cabeça, quase perfeitamente circulares, apresentando uma leve compressão ântero-ventralmente. Palpos labiais e maxilares alongados. Antena filiforme, chegando ao segmento abdominal III, composta por cerca de vinte antenômeros, cobertos por finas cerdas; escapo 1,3X mais longo que largo, comprimido dorso-ventralmente; pedicelo semi-cilíndrico, cerca de dois terços do comprimento do escapo. Primeiro flagelômero triangular em seção transversal.

Tórax (Figuras 22-25, 30): Pronoto sub-retangular em vista dorsal, aproximadamente 1,3X mais longo que largo; apresentando um par de espinhos grandes e bem desenvolvidos na margem posterior. Meso- e metatórax sub-cilíndricos em seção transversal, apresentando ao menos quatro espinhos conspícuos além de pequenas pontuações e tubérculos. Mesotórax aproximadamente 4,5X mais longo que o pronoto. Metanoto aproximadamente 5,4X mais longo que o segmento mediano; os dois combinados aproximadamente $0,8 \mathrm{X}$ o comprimento do mesonoto.

Pernas (Figuras 22-25, 30): Longas e delgadas. Fêmur trapezóide em seção transversal, apresentando carenas em todos os vértices. Profêmur curvo e compresso basalmente, de tamanho similar ao metafêmur e 1,4X mais longo que o mesofêmur. Tíbia retângular em seção transversal, apresentando pequenos pêlos nos vértices, levemente mais longa que o fêmur correspondente e apresentando area apicalis, porém pouco conspícua e parcialmente coberta por pêlos. Meso- e metatíbia podendo apresentar lóbulos nos vértices dorsais e ventrais posteriores e medianos. Protíbia 1,1X mais longa que metatíbia e 1,4X mais longa que a mesotíbia. Probasitarso aproximadamente $0,8 \mathrm{X}$ o comprimento dos 3 tarsômetos 
seguintes combinados, metabasitarso aproximadamente $0,4 \mathrm{X}$ o comprimento dos tarsômeros seguintes combinados e mesobasitarso $0,4 \mathrm{X}$ o comprimento dos tarsômeros seguintes combinados.

Abdômen (22, 23, 26, 30): Aproximadamente tão longo quanto cabeça, tórax e segmento mediano combinados. Segmentos abdominais mais longos do que largos, diminuindo gradativamente de comprimento a partir do VI até o IX. Tergito X 1,3X mais longo que o IX, estreitando gradativamente até a margem posterior, levemente arredondada. Cercos com cerca de um quinto do comprimento do tergito $\mathrm{X}$, mais estreitos basalmente, pilosos em sua porção distal. Placa subgenital alongada, mais larga em sua porção mediana, chegando às margens do tergito abdominal X e com margem afilada, apresentando uma carena mediana por toda a sua extensão.

Descrição do macho (Figuras 23-25, 27-28, 30):

Bicho-pau delgado, de tamanho pequeno para o gênero, com conspícuos espinhos amarelados.

Coloração (Figuras 23-25, 27-28, 30): Corpo predominantemente verde oliva. Um par de faixas pretas margeando lateralmente todo o corpo até o segmento abdominal VII, onde passa a ser a cor predominante. Antenas, cabeça, pronoto, segmento mediano e extremidades anterior e posterior do meso- e metanoto beges. Segmentos abdominais gradualmente mais beges em direção posterior, sendo a partir do segmento VIII completamente dessa cor. Segmentos abdominais IX e $\mathrm{X}$ mais escuros que os demais. Antenômeros, cabeça e pronoto com manchas marrom escuras irregulares. Antenômeros, olhos e palpos alaranjados. Olhos com uma distinta faixa negra horizontal percorrendo toda a sua extensão. Pronoto podendo apresentar manchas verde-oliva. Coxas beges, com manchas amarelas conspícuas nas articulações da meso- e metacoxa com o tórax. Pernas verde-oliva, mais claras que o corpo; pequenos pontos ou linhas marrom escuro podem estar presentes ao longo dos fêmures e tíbias. Articulações tíbia-fêmur e tíbia-tarso com mancha marrom escura. Tarsômeros bege alaranjados.

Cabeça (23, 24, 30): Alongada, lisa. Em vista dorsal sub-retangular, 1,18X mais longa que larga e 1,24X mais longa que o pronoto. Vértice chato. Olho composto pequeno, com quase um quarto do comprimento da cabeça, quase perfeitamente redondo, com um leve achatamento ântero-ventralmente. Palpos labiais e maxilares alongados. Antena filiforme, atingindo o segmento abdominal IV, similar a da fêmea; escapo 1,2X mais longo que largo, achatado dorso-ventralmente; pedicelo subcilíndrico, com cerca de dois terços do comprimento do escapo. Primeiro flagelômero triangular em seção transversal. 
Tórax $(23,24,30)$ : Pronoto sub-quadrado, meso- e metatórax subcilíndricos. Pronoto liso, sub-retangular em vista dorsal, cerca de 1,3X mais longo que largo, apresentando um par de espinhos na margem posterior como a fêmea. Mesotórax liso, aproximadamente 4,8X mais longo que o protórax, apresentando ao menos 4 pares de espinhos, nem sempre bem desenvolvidos. Metatórax e segmento mediano lisos; metanoto aproximadamente 5,9X mais longo que o segmento mediano e apresentando ao menos um par de espinhos em sua porção mediana; metatórax e segmento mediano combinados aproximadamente $0,8 \mathrm{X}$ o comprimento do mesotórax.

Pernas (23-25, 30): Longas e delgadas. Fêmur trapezóide em seção transversal, apresentando carenas em todos os vértices. Tíbia retangular em seção transversal, apresentando pequenos pêlos nos vértices; levemente mais longa que o fêmur correspondente e apresentando area apicalis, porém pouco conspícua e parcialmente coberta por pêlos. Profêmur curvo e comprimido basalmente, de comprimento similar ao metafêmur e ambos $1,3 \mathrm{X}$ mais longos que o mesofêmur. Protíbia levemente mais longa que a metatíbia e 1,4X mais longa que a mesotíbia. Pro- e metabasitarso $0,6 \mathrm{X}$ o comprimento dos tarsômeros seguintes combinados, mesobasitarso $0,5 \mathrm{X}$ o comprimento dos tarsômeros seguintes combinados.

Abdômen (23, 27-28, 30): Aproximadamente com o mesmo comprimento que a cabeça, tórax e segmento mediano combinados. Liso dorso e ventralmente, com um par de espinhos conspícuos nos segmentos II e III e por vezes apresentando espinhos até o tergito abdominal V, com uma pequena elevação mediana ao longo dos tergitos VIII, IX e X. Tergito $\mathrm{X}$ 1,2X mais longo que o IX, sua margem posterior bilobada com incisão mediana, pilosos ventralmente, apresentando na face ventral de cada lóbulo conjuntos de pequenos espinhos recurvados. Esternito VIII menor do que o tergito correspondente, mais largo do que longo. Póculo arredondado com poucos pêlos e quilha mediana conspícua em sua extremidade posterior terminando em uma margem alongada formando uma aba suavemente bipartida. Cercos com cerca de metade do comprimento do tergito $\mathrm{X}$, estreitos basalmente, densamente piloso em sua porção distal, de formato periforme. Vômer triangular, liso, cuja porção apical pode se alongar formando um pedúnculo onde estão presentes uma única projeção assimétrica.

Genitália (Figura 27): Esclerito dorsal tendo origem do lado esquerdo da estrutura da genitália quando em vista dorsal. De formato irregular e fino, formando uma estrutura levemente semicircular e torcida com a margem posterior terminando diagonalmente oposta a sua origem. O lóbulo dorsal é membranoso, fino, longo e de aspecto peduncular, afunilando quanto próximo a sua extremidade distal. A membrana basal do esclerito interno é cilíndrica, 
curta e robusta, normalmente envolvendo o esclerito interno dentro da estrutura da genitália, oculta pelo lóbulo dorsal, o lóbulo sinuoso ventral e o lóbulo basal. A porção apical do lóbulo sinuoso, porção apical do lóbulo basal e projeção bífida são bem esclerotizadas. A projeção bífida está localizada do lado esquerdo da genitália quando observada frontalmente. A membrana basal do esclerito interno é eversível, formando uma estrutura membranosa que acomoda em sua porção apical o apódema basal, discreto e em formato de escama, e o esclerito interno em formato de gancho, fortemente esclerotizado e assimétrico, e não muito maior que o apódema basal. O esclerito interno possui uma ponta arredondada, além de não apresentar nenhuma forma de ornamentação.

Descrição do ovo (28): Cápsula com formato similar a um feijão, cerca de $2 \mathrm{X}$ mais longa do que larga e 1,1X mais alta do que larga, redonda em seção transversal. Face ventral levemente côncava, dorsal levemente convexa e laterais levemente côncavas, quase chatas. Placa micropilar fortemente ornamentada, estendendo-se até a porção mediana da área polar; ornamentação projetando-se além da cápsula do ovo e de aspecto carnoso, frágil e quebradiça. Opérculo circular, angulado obliquamente em relação a altura da cápsula no sentido dorsal, ornamentado com um pseudo-capítulo oco, similar a uma rede. Cápsula recoberta por uma rede de cristas que apresentam cerdas por toda a sua extensão. Colar opercular ornamentado com pequenos dentes. Placa micropilar com formato de folha, mais estreita na porção apical. Cápsula marrom, cristas e opérculo marrom escuro, ornamentação da placa micropilar, cerdas e pseudo-capítulo bege.

\section{Descrição da Ninfa}

Ninfas de primeiro instar com corpo verde amarelado. Os olhos são amarelos, com uma linha escura longitudinal percorrendo medianamente sua extensão até a margem posterior da cabeça. As pernas possuem a mesma coloração do corpo, com tarsos de cor bege. Os sexos são facilmente reconhecidos após o terceiro instar, com fêmeas já apresentando padronagem de cor similar à fase adulta. Machos em fase ninfal apresentam coloração similar às fêmeas, adquirindo sua coloração característica apenas ao completar o desenvolvimento.

\section{Distribuição:}

Os espécimes coletados provém da localidade tipo, na região de Alto da Serra em Paranapiacaba, no município de Santo André, São Paulo, Brasil. A região está inserida na Serra do Mar, um contínuo de vegetação de Mata Atlântica caracterizada por florestas ombrófilas e estacionais semideciduais. Dada a extensão da Serra do Mar, é possível que a 
espécie seja encontrada em outras localidades.

Comentários: Material tipo de Canuleius scaber foi analisado na coleção onde se encontra depositado. O seu bom estado de conservação preservou características diagnósticas da espécie, em especial a morfologia geral do abdômen, órgão pré copulatório e estruturas do ovipositor da fêmea, permitindo a correlação do material com os espécimes depositados posteriormente coletados na localidade tipo. Além disso, os machos da espécie compartilham várias semelhanças com Canuleius vigintiquatuorspinosus Redtenbacher, 1906 e Canuleius vigintispinosus Redtenbacher, 1906, necessitando de mais estudos para elucidar sua relação com os demais táxons citados.

\section{Material Ccomplementar Analisado:}

Ninfa q (MZUSP \#0538) e $\oslash$ (MZUSP \#0537): Brasil, São Paulo, Santo André.

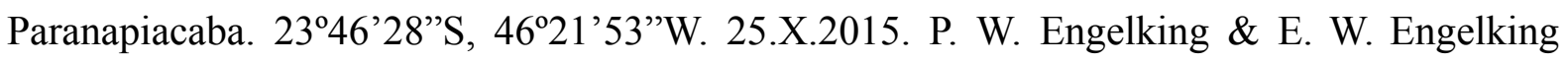

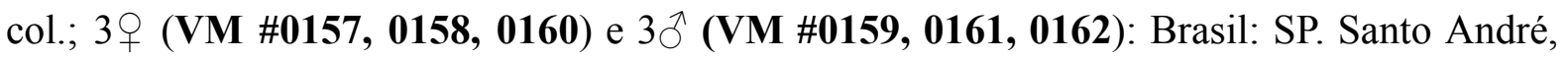
Paranapiacaba. $23^{\circ} 47^{\prime} 03.2^{\prime \prime S} 46^{\circ} 18^{\prime} 08.3^{\prime \prime} \mathrm{W}$. verão 2016. VM Ghirotto, PW Engelking col.

\subsection{Redescrição do Subgênero Miroceroys Toledo Piza, 1936}

Como o gênero. A justificativa de Piza (1936) para a criação de Miroceroys, com base em Ceroys (Miroceroys) saevissimus (Piza, 1936) se baseia na combinação da ornamentação apresentada pelas espécies descritas similares a Mirophasma Redtenbacher, 1906 e ao escapo liso e desarmado de Ceroys. À parte disso, a morfologia geral do corpo, ovos, genitália masculina e estrutura do ovipositor feminino apresentam os mesmos padrões do subgênero Ceroys. Das quatro espécies originalmente descritas, apenas duas são consideradas válidas nesta revisão: Ceroys (Miroceroys) heymonsi (Piza, 1936) e Ceroys (Miroceroys) saevissimus Westwood, 1859 sendo seu sinônimo júnior Ceroys (Miroceroys) redtenbacheri (Piza, 1936) syn. nov. Acima foi indicado que Ceroys (Miroceroys) brunneri syn. nov. é sinônimo de Ceroys (Ceroys) cristatus Redtenbacher 1906. É também identificada uma nova espécie de Ceroys (Miroceroys) sp. nov. para a região da Serra da Mantiqueira.

\subsubsection{Ceroys (Miroceroys) heymonsi (Piza, 1936)}

(Figuras 31 a 39, Tabelas 8 e 9)

Ceroys (Miroceroys) heymonsi Zompro, 2004; Zompro \& Domenico. 2005. Otte \& Brock. 2005. Figueiredo de Araujo \& Garraffoni. 2012.

Holótipo 1 q (sem número): São Paulo, Alto da Serra, Col. D. Braz. 
Parátipo $3 q$ (sem número): São Paulo, Alto da Serra, Col. Braz, 1119.

Diagnose. Ambos os sexos apresentam uma considerável quantidade e grau de desenvolvimento de tubérculos, espinhos corporais, e áreas serrilhadas e lóbulos nas pernas, tórax e abdômen se comparados a Ceroys (Ceroys) perfoliatus. Fêmeas de Ceroys (Miroceroys) heymonsi são diferenciadas das demais espécies de Ceroys (Miroceroys) pela presença de lóbulos em formato de crista fusionados com projeções em formato de escama nas margens posteriores nos tergitos III-VIII (Figuras 32 e 40) corpo densamente granulado e projeções torácicas de formato mais arredondado (Figuras 32 40). Machos são diferenciados de outras espécies de Ceroys (Ceroys) pelos espinhos dorsolaterais irregulares e discretos orientados em direção ao abdômen (Figuras 32, 34 e 39), o abdômen com marcas de constrição pouco evidentes e cercos cilíndricos bem desenvolvidos.

\section{Redescrição da fêmea (Figuras 31-34, 39)}

Bicho-pau de médio porte, distintamente mais robusta que o macho. Corpo ornamentado com lóbulos, tubérculos e espinhos, com ornamentação característica em crista no abdômen.

Coloração (Figuras Figuras 31-34, 39). O corpo varia entre tons de verde, bege e marrom normalmente em tons mais escuros que os machos. Meta- e mesotórax e segmento mediano apresentando uma inconspícua linha mediana de tonalidade levemente mais clara que o resto do corpo. Palpos e mandíbulas amarelo escuro. Olhos amarelados cobertos por manchas irregulares escurecidas. Cabeça apresentando os mesmos tons do corpo, com uma linha longitudinal lateral percorrendo da margem posterior até atrás dos olhos. Pernas são normalmente rajadas ou manchadas em tons mais escuros de marrom, incluindo os tarsômeros, com a porção anterior do pro- meso e metafêmur normalmente bege esverdeados. Tubérculos e espinhos podem apresentar pontas mais claras em tons de bege e laranja.

Cabeça (Figuras 31-32, 39). Levemente alongada e distintamente tuberculada. Subretangular em vista lateral e elíptica dorsalmente, cerca de 1.5x mais longa que larga e cerca de $1.3 \mathrm{x}$ mais longa que o pronoto. Vértex convexo, apresentando um par de espinhos lateralmente orientados de aparência rugosa, densamente tuberculado, com margens lobadas irregularmente e ápice terminando em uma ponta aguda. (Figuras 32). Olhos compostos relativamente pequenos, redondos, projetando-se lateralmente e levemente orientados anteriormente. Antena filiforme alcançando o segmento abdominal IV-V quando estendidos posteriormente. Escapo armado, apresentando pequenos espinhos na margens externas anteriores Órgão antenal conspícuo, amarelado, largo, presente na margem dorsal posterior do 
décimo segundo antenômero.

Tórax (Figuras 31-33, 39). Protórax subquadrado em seção transversal, meso- e metatórax sub-cilíndricos. Pronoto densamente tuberculado, rugoso, com sulcos profundos, sub-retangular em vista dorsal, levemente elevado posteriormente, cerca de 1.1x mais longo do que largo, apresentando dorsalmente um par de espinhos posteriores bem desenvolvidos e tuberculados, além de vários tubérculos de tamanho variado por todo o pronoto. Mesotórax rugoso, tuberculado, cerca de 3,4x maior que o protórax, apresentando dorsalmente alguns espinhos paramedianos assimétricos. Ao menos um par localizado próximo a margem posterior, e um par de ornamentações foliáceas e lanceoladas, bem arredondadas, de margens irregulares, rugosas, tuberculadas e achatadas dorsoventralmente dispostas lateralmente, com ápice terminando em uma ponta aguda (Figuras 31 e 33), além de dois pares menores de espinhos cônicos dispostos anterior e posteriormente. Metatórax e segmento mediano rugosos, tuberculados (Figura 33); metatórax, cerca de 2.4x mais longos que o segmento mediano; mesotórax cerca de 1.42x mais longo que o metatórax e o segmento mediano combinados. Metatórax apresentando centralmente um par de ornamentações foliáceas orientadas lateralmente similares às presentes no mesotórax, apresentando um par de espinhos cônicos na divisão entre o metatórax e o segmento mediano. Meso- e metaepimero projetando-se além dos respectivos segmentos, mesoepmero curto; coxopleurito irregular, tuberculado; meso- e metaepisterno projetados lateralmente como um lóbulo irregular com um espinho apical (Figura 33).

Pernas (Figuras 31-33, 39). Pernas posteriores ultrapassando o final do segmento abdominal X quando estendidas posteriormente. Fêmures carenados e tuberculados, apresentando espinhos cônicos e projeções foliáceas e fracamente tuberculados na carena ventral. Meso- e metafêmur apresentando lóbulos rugosos distintos de variados tamanhos tanto nas carenas dorsais quando ventrolaterais. Tibia com com carenas pouco proeminentes, pouco tuberculada e densamente ornamentada com pequenas projeções foliáceas.

Abdômen (Figuras 31, 34, 49). Segmentos II-VII com uma constrição central suave. Tergitos abdominais apresentando ornamentação similar a de Ceroys (Ceroys) cristatus, com exceção de que as cristas são formadas por projeções medianas de escamas perpendiculares à margem posterior dos tergitos abdominais, normalmente bem desenvolvidas e que se estendem para além dos limites do tergito seguinte. Tergito $\mathrm{X}$ irregular, quilhado, rugoso, com sua margem posterior alargada e lobada formando três projeções de aspecto geométrico distintas (Figura 34). Placa subgenital elíptica, com margem posterior arredondada (Figura 34), no geral não ultrapassando a margem do tergito $X$; apresentando um quilha nos dois terços da porção anterior, tuberculada de forma mais intensa a partir de sua porção mediana. 
Orgão pré opercular pouco proeminente, escurecido, rugoso, sendo delimitado por projeções laterais discretas do tergito VIII e uma discreta quilha mediana (Figura 34).

Descrição do Macho (Figuras 31-33, 35-36, 38)

Bicho-pau áptero, esguio e apresentando espinhos serrilhados pelo corpo de forma abundante, com projeções na cabeça e tórax recurvadas para trás.

Coloração (Figuras 31-33, 35-36, 38). Como o gênero. Não apresenta nenhuma linha mediana no meta- e mesotórax, Cabeça com uma linha longitudinal lateral percorrendo da margem posterior da cabeça até atrás dos olhos. Olhos amarelados. Antenas marrom claro dorsalmente, escurecidas ventralmente. Pernas normalmente são rajadas ou manchadas em tons mais escuros de marrom, incluindo os tarsômeros, com a porção anterior do pro-, mesoe metafêmur esverdeados, como nas fêmeas. Tubérculos e espinhos completamente beges, marrons ou pretos, apresentando pontas mais claras em tons de amarelo e laranja; ornamentações torácicas lobadas seguem o padrão de coloração do corpo, mais claras dorsalmente e escurecidas ventralmente.

Cabeça (Figuras 31-32, 38). Levemente alongada e tuberculada. Ovóide em vista dorsal, cerca de 1.1x mais longa que larga, com cerca do mesmo comprimento do pronoto. Vértex gentilmente convexo com um par de espinhos lateralmente orientados e normalmente posteriormente curvados. Antena filiforme chegando ao segmento abdominal X quando estendida posteriormente. Órgão antenal conspícuo, levemente menor que o da fêmea, presente na margem posteior dorsal do décimo terceiro antenômero.

Tórax (Figuras 31-33, 38). Protórax subquadrado em seção transversal, meso- e metatórax sub-cilíndricos. Pronoto tuberculado, com sulcos profundos, sub-retangular em vista dorsal em formato de sela, posteriormente elevado, cerca de 1.1 mais longo do que largo. Apresenta dorsalmente um par de pequenos espinhos medianos logo antes da sutura mediana e ou outro par de espinhos maiores e mais robustos na margem posterior, assim como nas fêmeas. Mesotórax liso, cerca de 3,9x mais longo do que o protórax, tuberculado lateral e dorsalmente e apresentando ao menos um par de espinhos assimétricos próximos à margem anterior, um par simétrico na margem posterior e um par de espinhos cônicos, dorso-ventralmente achatados e lateralmente orientados em sua porção mediana, normalmente curvados de forma sutil em direção ao abdômen. Metatórax e segmento mediano tuberculados como no metatórax (Figura 33); metatórax cerca de 3x mais longo que o segmento mediano, mesotórax cerca de $1.3 \mathrm{x}$ mais longo que o metatórax e segmento medianos combinados. Metatórax apresentando em sua porção central um par de espinhos cônicos achatados dorsoventralmente e lateralmente orientados como no mesotórax, além de 
um par de espinhos cônicos menores e bem desenvolvidos na divisão entre o metatórax e o segmento mediano. Meso- e metaepímero se projetando além de seus respectivos segmentos, mesoepímero curto; coxopleurito irregular, tuberculado; meso- e metaepisterno projetados lateralmente como lóbulos irregulares, com espinhos apicais conferindo uma aparência serrilhada.

Pernas (Figuras 31-33, 38): Os fêmures apresentam todas as carenas levemente quilhadas, tuberculadas e apresentando projeções em formato de lóbulos ou espinhos cônicos. Meso- e metafêmur apresentando ornamentações como nas fêmeas, porém de forma mais discreta e irregular. Tíbia similar à fêmea, com leve carenas, tuberculadas e apresentando projeções foliáceas. Basitarsos com cerca do mesmo tamanho de todos os outros tarsômeros combinados.

Abdômen (Figuras 31, 35-36, 38). Distintamente tuberculado e levemente rugoso até sua metade posterior. Segmentos II-VII mais longos que largos, VIII-IX mais largos que longos, $\mathrm{X}$ tão longo quanto largo. Segmentos gradualmente diminuindo de tamanho entre os segmentos VI a IX. Segmentos II-VIII com uma constrição central, gradualmente se intensificando nos segmentos mais posteriores. Tergitos II e III apresentam um par de espinhos próximos à margem posterior; tergito VIII alargado consideravelmente em sua porção posterior. Tergitos VIII-X com uma carena contínua conspícua central e duas paramedianas. Tergitos VII-IX com uma margem posterior elevada e arredondada. Tergito X cerca de 1.3x mais longo que o IX; Com margem posterior distintamente emarginada (Figura 35), formando dois lóbulos laterais, cada qual apresentando uma placa dentada com pequenos espinhos curtos, robustos e curvos (Figura 35). Esternito VIII mais curto que o tergito correspondente, mais largo que longo e apresentando posteriormente duas quilhas projetadas paramedianamente. Esternito IX formando um póculo de formato distinto, côncavo, similar a uma xícara (Figura 35); região ventral com uma carena mediana conspícua se estendendo à uma confluência posterior aguda, com margem fortemente esclerotizada. Paraprocto curto, curvado internamente, epiprocto quilhado, largo e triangular. Cercos cilíndricos, não apresentando afunilando apical ou achatamento dorsoventral como nas demais espécies (Figura 35).

Genitália (Figura 36): Similar a de Ceroys (Ceroys) perfoliatus, mas apresentando estruturas muito mais delicadas. O esclerito dorsal não apresenta um prolongamento em sua margem, orientado ventralmente. O lóbulo dorsal membranoso e largo. A membrana basal do esclerito interno é cilíndrica, normalmente envolvendo o esclerito interno dentro da estrutura da genitália, oculta pelo lóbulo dorsal, o lóbulo sinuoso ventral e o lóbulo basal. A porção apical do lóbulo sinuoso, porção apical do lóbulo basal e projeção bífida são levemente 
esclerotizadas. A projeção bífida está localizada do lado direito da genitália quando observada frontalmente. A membrana basal do esclerito interno é eversível, formando uma estrutura membranosa cilíndrica que acomoda em sua porção apical o apódema basal, discreto e em formato de escama, e o esclerito interno em formato de gancho, fortemente esclerotizado e assimétrico, curvado para a esquerda. A ponta do esclerito interno é fortemente arredondada, além de não possuir nenhuma forma de ornamentação.

\section{Descrição dos ovos (Figura 37)}

De coloração clara, normalmente beges. Apresenta aparência similar aos demais ovos de Ceroys, com as cristas da cápsula formando figuras geométricas, normalmente hexagonais. $\mathrm{O}$ opérculo circular com superfície similar ao resto da cápsula do ovo e apresentando quatro aberturas centrais, um conjunto de projeções de cristas e várias aberturas laterais, margeando o limite do opérculo. Micrópila com uma linha mediana distinta, se estendendo da margem posterior da placa micropilar até sua base, percorrendo cerca de $2 / 5$ do seu comprimento. Placa micropilar externa distinta, depressa, arredondada, com superfície brilhante e rugosa, com uma leve elevação enrugada do poro micropilar no meio da placa. Poro micropilar escurecido, anteriormente convexo. Linha mediana contínua com as margens da placa micropilar, elevadas formando um margem rugosa e irregular, mais fina e clara que as cristas da cápsula do ovo, porém externamente conectadas.

Distribuição. Ceroys (Miroceroys) heymonsi conhecido do Paraná até a região de Cotia, em São Paulo, Brasil, sendo encontrado tanto Mata Atlântica do interior do continente quanto em áreas da Serra do Mar voltadas para o interior do Continente.

\section{Material complementar analisado:}

1 (MELQ \#497) Alto da Serra, São Paulo, Santos. W. Bokermann col. IX.1952; 1 \% (MELQ \#498) Alto da Serra, São Paulo. E. Schw. col. 25.IV.1938; 1 (MELQ \#502) Alto da Serra, São Paulo. E. Schw. col. IV.1936; 10 (MELQ \#495) Alto da Serra, São Paulo. E. Schw. col. IV.1937; 1ð̂ (MELQ \#496); 1 † (MELQ \#500) Alto da Serra, São Paulo. E. Schw. col. 30.VI.1937; 1 q (MZUSP \#0009): São Paulo, Paranapiacaba. IX.1953. Werner col.; 1ठ (MZUSP \#0605): Brasil, São Paulo, São Lourenço da Serra. 2355'41”'S, 46 54'18’W. 21.XI.2015. P. W. Engelking e E. W. Engelking col.; P. I. Chiquetto-Machado e A. Z. Ramin col.; 5 (MZUSP \#1175, \#1177, \#1178, \#1179, \#1180), $2 \hat{\jmath}$ (MZUSP \#1176, \#1181): Brasil, São Paulo, Tapiraí, antes da Trilha dos Tucanos. 2400'29”S, 47³3'50.2"W. 12.I.2019. Em samambaias. Fixados em II.2019. V. M. Ghirotto col.; 2 (MZUSP \#1243, 
\#1244), 3ð (MZUSP \#1240, \#1241, \#1242) e ovos: Brasil, São Paulo, Parque Estadual de Intervales, próximo a pousada Onça Pintada. 24¹6’04”S, 48²4’53”W. 14-17.III.2019. E. B. Crispino col; $1 q$ (MZUSP \#0874) e ovos: Brasil, Paraná, Reserva Ecológica do Bom Jesus. 25¹8’20”S, 4840’44’W. 22.I.2017..

\subsubsection{Ceroys (Miroceroys) saevissimus Westwood, 1859}

(Figuras 40 a 49, Tabelas 10 e 11)

Ceroys saevissimus Westwood. 1859.

Acanthoclonia saevissimus Kirby, W.F. 1904.

Mirophasma saevissimum Redtenbacher. 1906.

Ceroys (Miroceroys) saevissimus Zompro. 2004; Otte \& Brock. 2005. Figueiredo de Araujo

\& Garraffoni. 2012. Brock, J.A. Marshall, Beccaloni \& Harman. 2016.

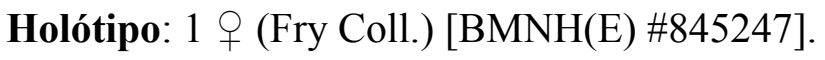

$=$ Ceroys (Miroceroys) redtenbacheri Piza, 1936 syn. nov.

Miroceroys redtenbacheri Piza. 1936. Piza. 1946.

Ceroys (Miroceroys) redtenbacheri Zompro. 2004. Zompro \& Domenico. 2005. Otte \& Brock. 2005. Figueiredo de Araujo \& Garraffoni. 2012

Holótipo: $1 \bigcirc \widehat{~(M Z U S P ~ \# 0015): ~ B r a s i l, ~ R i o ~ d e ~ J a n e i r o, ~ S e r r a ~ d e ~ M a c a e ́ . ~}$

Diagnose. Possivelmente a mais ornamentada de todas as espécies do gênero, ambos os sexos apresentam uma considerável quantidade e grau de desenvolvimento de tubérculos, espinhos corporais, áreas serrilhadas e lóbulos nas pernas, tórax e abdômen incomparáveis as demais espécies de Ceroys. Ambos os sexos apresentam um distinto abaulamento mediano no mesotórax. Lóbulos e projeções foliáceas do tórax, abdômen e pernas apresentam espinhos robustos e pontiagudos, além de uma constrição mediana muito mais proeminente nos segmentos abdominais e das margens anteriores e posteriores dos tergitos possuírem espinhos e tubérculos irregulares que se projetam além da margem do corpo. Fêmeas de Ceroys (Miroceroys) saevissimus apresentam ainda uma marcação clara na parte ventral do tórax, abaixo do abaulamento, e um alongamento posterior do tergito $\mathrm{X}$ que, junto do alongamento da placa subgenital, formam uma estrutura para auxiliar a fêmea a enterrar os ovos (Figura 44). Machos são diferenciados de outras espécies de Ceroys (Ceroys) pelo póculo distintamente maior e mais desenvolvido que nas outras espécies (Figura 45) e cercos proeminentes e cilíndricos. 
Redescrição da Fêmea (Figuras 40-44, 48)

Bicho-pau de médio porte, distintamente mais robusta que o macho. Corpo ornamentado com lóbulos, tubérculos e espinhos, com ornamentação pontiaguda e irregular.

Coloração (Figuras 40-44, 48): O corpo varia entre tons de verde e marrom escuro, normalmente em tons mais claros que os machos. Meta- e mesotórax e segmento mediano apresentando linha mediana clara, além de uma marcação branco ou amarelada no mesotórax abaixo do abaulamento. Palpos e mandíbulas amarelo escuro. Olhos amarelados cobertos por manchas irregulares escurecidas. Cabeça apresentando diferentes tons da mesma cor que o corpo, com uma linha longitudinal lateral percorrendo da margem posterior até atrás dos olhos. Pernas são normalmente rajadas ou manchadas em tons mais escuros de marrom, incluindo os tarsômeros, com a porção anterior do pro- meso e metafêmur normalmente bege esverdeados. Tubérculos e espinhos normalmente apresentam pontas mais claras em tons de bege e laranja.

Cabeça (Figuras 40-42, 48). Levemente alongada e fortemente tuberculada. Sub-retangular em vista lateral e elíptica dorsalmente, cerca de $1.5 \mathrm{x}$ mais longa que larga e cerca de $1.3 \mathrm{x}$ mais longa que o pronoto. Vértex convexo, apresentando um par de espinhos lateralmente orientados de aparência rugosa, densamente tuberculados, com margens lobadas irregularmente e ápice terminando em uma ponta aguda. (Figura 42). Olhos compostos relativamente pequenos, redondos, projetando-se lateralmente e levemente orientados anteriormente. Palpos labiais e maxilares robustos, com segmentos terminais ovalados e arredondados. (Figura 42). Antena filiforme alcançando o segmento abdominal IV-V quando estendidos posteriormente. Escapo armado, podendo apresentar um ou mais espinhos bem desenvolvidos na margem distal, levemente mais longo do que largo, achatado dorsoventralmente; pedicelo sub cilíndrico, com mais da metade do tamanho de comprimento do escapo.

Tórax (Figuras 40-43, 48). Protórax subquadrado em seção transversal, meso- e metatórax sub-cilíndricos. Pronoto densamente tuberculado, rugoso, com sulcos profundos, sub-retangular em vista dorsal, levemente elevado posteriormente, cerca de 1.1x mais longo do que largo, apresentando dorsalmente um par de espinhos medianos posicionados logo antes da sutura mediana, além de um par de espinhos maiores posteriores. Mesotórax rugoso, tuberculado, cerca de 3,4x maior que o protórax, apresentando dorsalmente alguns espinhos paramedianos assimétricos. Ao menos um par localizado próximo a margem posterior, e um par de ornamentações foliáceas e lanceoladas, irregulares, rugosas, tuberculadas e achatadas dorsoventralmente dispostas lateralmente, com ápice terminando em uma ponta aguda (Figuras 41 e 43), além de dois pares menores de espinhos cônicos dispostos anterior e 
posteriormente. Abaulamento dorsal do mesotórax localizado logo abaixo da ornamentação foliácea. Metatórax e segmento mediano rugosos, tuberculados (Figuras 43); metatórax, cerca de 2.4x mais longos que o segmento mediano; mesotórax cerca de $1.42 \mathrm{x}$ mais longo que o metatórax e o segmento mediano combinados. Metatórax apresentando centralmente um par de ornamentações foliáceas orientadas lateralmente similares às presentes no mesotórax, apresentando um par de espinhos cônicos na divisão entre o metatórax e o segmento mediano. Meso- and metaepimero projetando-se além dos respectivos segmentos, mesoepimero curto; coxopleurito irregular, tuberculado; meso- e metaepisterno projetados lateralmente como um lóbulo irregular com um espinho apical (Figura 43).

Pernas (Figuras 40-43, 48). Pernas posteriores ultrapassando o final do segmento abdominal X quando estendidas posteriormente. Fêmures carenados e tuberculados, apresentando espinhos cônicos e projeções foliáceas e fracamente tuberculados na carena ventral. Meso- e metafêmur apresentando lóbulos rugosos distintos de variados tamanhos tanto nas carenas dorsais quanto ventro-laterais. Tibia carenada, tuberculada e apresentando projeções foliáceas dorsalmente.

Abdômen (Figuras 40-41, 44). Similar a Ceroys (Miroceroys) heymonsi, porém tanto a ornamentação quanto a constrição dos segmentos abdominais é muito mais pronunciada. Tergito $\mathrm{X}$ irregular, quilhado, rugoso, com sua margem posterior alargada e lobada de forma lanceolada, se estendendo para além do limite do epiprocto. (Figura 44). Placa subgenital elíptica, com margem posterior arredondada (Figura 44), nunca ultrapassando a margem do tergito X; apresentando um quilha nos dois terços da porção anterior, tuberculada de forma mais intensa a partir de sua porção mediana. Orgão pré opercular distintamente proeminente, escurecido, rugoso, projetado ventralmente e margeado por extensões curvadas interiormente do esclerito VIII. (Figura 44).

Descrição do macho (Figuras 41-43, 45, 49)

Bicho-pau áptero, fino e densamente ornamentado, com espinhos bem desenvolvidos, triangulares e de margens serradas e mesotórax abaulado ventralmente, com terminália do abdômen de aspecto inchado, contrastando com o abdômen fino e de segmentos constritos.

Coloração $(41-43,45,49)$. Como o gênero, o corpo no geral apresenta tons muito escuros de marrom e preto. Meta- e mesotórax, junto com o segmento mediano e tergitos II e III apresentam uma inconspícua linha, por vezes mais clara, por vezes mais escura que a cor predominante no corpo. Cabeça apresentando o mesmo tom de cor do corpo, geralmente rajada em tons de verde. Olhos amarelados. Antenas marrom claro dorsalmente, escurecidas ventralmente. Pernas normalmente são rajadas ou manchadas em tons de verde, incluindo os tarsômeros, com a porção anterior do pro-, meso- e metafêmur esverdeados, como nas 
fêmeas. Tubérculos e espinhos esverdeados, apresentando pontas mais claras; ornamentações torácicas lobadas seguem o padrão de coloração do corpo, mais claras dorsalmente e escurecidas ventralmente.

Cabeça (Figuras 41-42, 49). Como para o gênero, levemente alongada e densamente tuberculada. Ovóide em vista dorsal, cerca de 1.1x mais longa que larga, com cerca do mesmo comprimento do pronoto. Vertex proeminentemente convexo com um par de espinhos lateralmente orientados, densamente tuberculados. Olhos como o gênero. Antenas chegando ao segmento abdominal $\mathrm{X}$ quando estendida posteriormente. Escapo armado, apresentando um espinho externo na margem distal; pedicelo sub cilíndrico, com mais da metade do tamanho do escapo. Órgão antenal conspícuo, levemente menor que o da fêmea, presente na margem posterior dorsal do décimo terceiro antenômero.

Tórax (Figuras 41-43, 49): Protórax subquadrado em seção transversal, meso- e metatórax sub-cilíndricos. Pronoto tuberculado, com sulcos profundos, sub-retangular em vista dorsal em formato de sela, posteriormente elevado, cerca de 1.1X mais longo do que largo. Apresenta dorsalmente um par de pequenos espinhos medianos logo antes da sutura mediana e ou outro par de espinhos maiores e mais robustos na margem posterior, assim como nas fêmeas. Mesotórax liso, cerca de 3,9x mais longo do que o protórax, tuberculado lateral e dorsalmente e apresentando ao menos um par de espinhos assimétricos próximos à margem anterior, um par simétrico na margem posterior e um par de espinhos cônicos, dorso-ventralmente achatados e lateralmente orientados em sua porção mediana, serrilhados. Abaulamento do mesotórax localizado diretamente abaixo do par de espinhos achatados. Metatórax e segmento mediano tuberculados como no metatórax (Figura 43); metatórax cerca de 3x mais longo que o segmento mediano, mesotórax cerca de $1.3 \mathrm{x}$ mais longo que o metatórax e segmento medianos combinados. Metatórax apresentando em sua porção central um par de espinhos cônicos achatados dorso-ventralmente, lateralmente orientados e serrilhados como no mesotórax, além de um par de espinhos cônicos menores e bem desenvolvidos na divisão entre o metatórax e o segmento mediano. Meso- e metaepímero se projetando além de seus respectivos segmentos, mesoepímero curto; coxopleurito irregular, tuberculado; meso- e metaepisterno projetados lateralmente como lóbulos irregulares, com espinhos apicais conferindo uma aparência serrilhada.

Pernas (Figuras 41-42, 49). Como nas fêmeas. Fêmures apresentam todas as carenas levemente quilhadas, tuberculadas e apresentando projeções em formato de lóbulos ou espinhos cônicos. Meso- e metafêmur apresentando ornamentações como nas fêmeas, porém de forma mais discreta e irregular. Tíbia como nas fêmeas, porém de forma menos acentuada.

Abdômen (Figuras 41, 45-46). Muito similar à Ceroys (Ceroys) cristatus, mas 
apresentando menos tubérculos, mais espinhos serrilhados e uma constrição dos segmentos abdominais com projeções espinhosas muito bem marcadas. Tergito X cerca de 1.3x mais longo que o IX; Com margem posterior distintamente emarginada (Figura 44), formando dois lóbulos laterais, cada qual apresentando uma placa dentada com pequenos espinhos curtos, robustos e curvos (Figura 45). Esternito VIII mais curto que o tergito correspondente, mais largo que longo e apresentando posteriormente duas quilhas projetadas paramedianamente. Esternito IX formando um póculo de formato distinto, côncavo, similar a uma xícara (Figura 46); região ventral com uma carena mediana conspícua se estendendo à uma confluência posterior aguda, com margem fortemente esclerotizada. Paraprocto curto, curvado internamente, epiprocto quilhado, largo e triangular. Cercos distintamente cilíndricos, esguios, e curvados internamente (Figura 45).

Genitália (Figura 46): Estrutura da genitália organizada de forma espelhada se comparada à Ceroys (Ceroys) perfoliatus. Esclerito dorsal tendo origem do lado esquerdo da estrutura da genitália quando em vista dorsal. Tem formato irregular, com a margem posterior terminando diagonalmente oposta a sua origem e apresentando um prolongamento em sua margem orientado ventralmente, onde o lóbulo dorsal está associado. O lóbulo dorsal membranoso, largo. A membrana basal do esclerito interno é cilíndrica, normalmente envolvendo o esclerito interno dentro da estrutura da genitália, oculta pelo lóbulo dorsal, o lóbulo sinuoso ventral e o lóbulo basal. A porção apical do lóbulo sinuoso, porção apical do lóbulo basal e projeção bífida são bem esclerotizadas. A projeção bífida está localizada do lado esquerdo da genitália quando observada frontalmente. A membrana basal do esclerito interno é eversível, formando uma estrutura membranosa cilíndrica que acomoda em sua porção apical o apódema basal, discreto e em formato de escama, e o esclerito interno em formato de gancho, fortemente esclerotizado e assimétrico, curvado para a direita. A ponta do esclerito interno é fortemente arredondada, e é completamente lisa ao longo de toda sua extensão.

\section{Descrição dos Ovos (Figura 47)}

De coloração marrom escura ou preta. Com formato de barril, levemente côncavos dorsalmente, cerca de 1.6x mais longos do que largos. As cristas reticuladas normalmente presentes nos ovos de Ceroys são mais discretas na espécie, ficando gradativamente mais conspícuas à medida que se aproximam do opérculo. Formam padrões pequenos e irregulares, sendo difícil discernir formas geométricas. Como consequência, as aberturas presentes na cápsula são bem menores que nas demais espécies de Ceroys. O opérculo é circular e não possui aberturas, apenas prolongamentos medianos. Micrópila (Figura 47) com uma linha 
mediana distinta, se estendendo da margem posterior da placa micropilar até sua base, percorrendo cerca de $2 / 5$ do seu comprimento. Placa micropilar externa distinta, depressa, lanceolada, quase elíptica, com superfície opaca e de aspecto poroso, com uma leve elevação enrugada do poro micropilar no meio da placa. Poro micropilar escurecido, anteriormente convexo. Linha mediana contínua com as margens da placa micropilar, elevadas formando um margem rugosa e irregular, mais fina e clara que as cristas da cápsula do ovo, porém externamente conectadas.

Distribuição. Ceroys (Ceroys) saevissimus é conhecido para a região da Serra do Mar que abrange as localidades de Salezópolis, Boracéia e regiões circundantes em São Paulo, Brasil, alem Minas Gerais e Rio de Janeiro, sendo encontrado tanto em regiões da Serra do Mar quanto em trechos de Mata Atlântica do interior do continente.

Comentários: Material tipo de Ceroys (Miroceroys) saevissimus foi analisado através de fotos enviadas por Pablo Vallero e das ilustrações originais de Westwood. Ambas estão em boa qualidade, mostrando características diagnósticas da espécie, especialmente detalhes do padrão de ornamentação e, no caso das fotos, estruturas do ovipositor da fêmea. Além disso, as fotos permitiram identificar que um dos exemplares listados na série tipo depositados no NHMUK, o espécime BMNH(E) \#878200, é na verdade uma fêmea adulta de Ceroys (Ceroys) cristatus dada as diferenças marcantes de morfologia corporal e estruturação da terminália e estruturas do ovipositor. Não obstante, apenas o espécime [BMNH(E) \#845247] possuí a etiqueta "Holotypus" e Westwood menciona "A fêmea" durante toda sua descrição original, indicando que o espécime $\mathrm{BMNH}(\mathrm{E}) \# 878200$ foi posteriormente e erroneamente identificado como sendo da mesma espécie, além de erroneamente ser designado como parte da série tipo. A presença de material referente a ambos os sexos na coleção do MZUSP permitiu a correlação entre Ceroys (Miroceroys) saevissimus e seu sinônimo, Ceroys (Miroceroys) redtencacheri.

\section{Material complementar analisado:}

10 (MELQ \#501) Estação Ecológica de Boracéia, Salesópolis, São Paulo. 850 m. Rabello col. 15.II.1962; $1 \sigma^{\Uparrow}$ (MZUSP \#0008): Brasil, São Paulo, Boracéia: Salesópolis. XII.1943. Zokkey col.; 19 (MZUSP \#0104): Brasil, São Paulo, Salesópolis, Estação Biológica de Boracéia. X.1965. Rita col.; $1 \widehat{\jmath}$ (MZUSP \#00007): Brasil, São Paulo, Salesópolis, Reserva da Casa. 26I.1974. E. G. Froehlich col.; 19 (MZUSP \#0017): Brasil, São Paulo, entre Paraty e Ubatuba. 1.V.1975. A. B. Joly col. 1 q (MZUSP \#0105): Brasil, São Paulo, Estação 


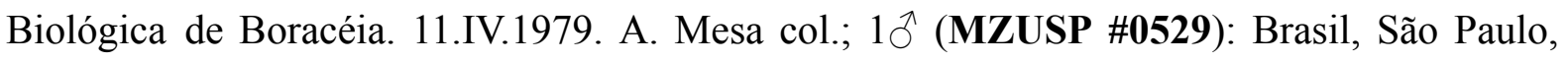
Boracéia. 14-20.IV.1984. A. Mesa, D. Cella, F. Mello, C. Fontanetti e J. Ramos col.; 1 \% (MZUSP \#0600), 1 $\sigma^{\Uparrow}$ (MZUSP \#0529) e ovos: Brasil, São Paulo, Salesópolis, Estação Biológica de Boracéia. 2339'S, 4353'W. 6-8.II.2016. P. I. Chiquetto-Machado e A. Z. Ramin col.; $1 \sigma^{\Uparrow}$ (MZUSP \#0529): Brasil, São Paulo, Salesópolis, Estação Biológica de

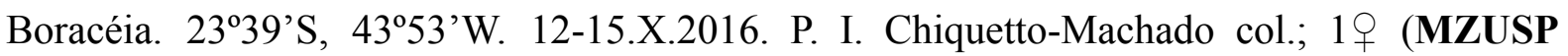
\#0903), $1 ð$ (MZUSP \#0905) e ovos: Brasil, São Paulo, Salesópolis, Estação Biológica de

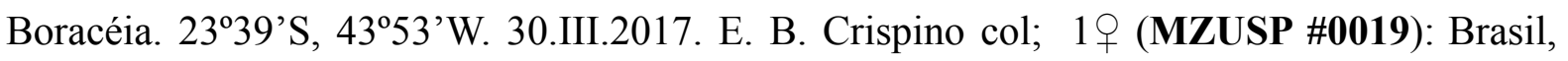
Minas Gerais, Lagoa Santa. 26.XI.1960. Araújo e Martins, col.

\subsubsection{Ceroys (Miroceroys) sp. nov.}

(Figuras 50 - 59, Tabelas 12 e 13)

Diagnose. Ambos os sexos apresentam uma diminuição considerável no grau de ornamentação, com menos tubérculos, áreas serrilhadas e lóbulos nas pernas, tórax e abdômen. Fêmeas de Ceroys (Miroceroys) sp. nov. são diferenciadas das demais espécies de Ceroys (Miroceroys) pela ausência dos lóbulos em formato de crista nos tergitos III-VIII (Figuras 50, 53, 54 e 58) e lóbulos metatorácicos mais finos e lanceolados (Figuras 50, 53, 54 e 58). Machos são diferenciados de outras espécies de Ceroys (Miroceroys) pelos espinhos mesotorácicos dorso-laterais mais lisos e menos robustos (Figuras 50 e 53), o abdômen com marcas de constrição menos evidentes, os cercos mais largos e achatados na base e os espinhos torácicos cônicos sem projeções secundárias.

\section{Descrição da Fêmea (Figuras 50-54, 58 e 59)}

Bicho-pau de médio porte, distintamente mais robusta que o macho. Corpo ornamentado com lóbulos, tubérculos e espinhos.

Coloração (Figuras 50-54, 58 e 59): O corpo varia entre tons de bege e marrom dourado à escuro, normalmente em tons mais escuros que os machos. Meta- e mesotórax e segmento mediano apresentando linha mediana escurecida. Palpos e mandíbulas amarelo escuro. Olhos amarelados cobertos por manchas irregulares escurecidas. Cabeça apresentando diferentes tons de marrom, preto e bege, com uma linha longitudinal lateral percorrendo da margem posterior até atrás dos olhos. Pernas são normalmente rajadas ou manchadas em tons mais escuros de marrom, incluindo os tarsômeros, com a porção anterior do pro- meso e metafêmur normalmente bege esverdeados. Tubérculos e espinhos normalmente apresentam pontas mais claras em tons de bege e laranja.

Cabeça (50, 51 e 58). Levemente alongada e distintamente tuberculada. 
Sub-retangular em vista lateral e elíptica dorsalmente, cerca de $1.5 \mathrm{x}$ mais longa que larga e cerca de 1.3x mais longa que o pronoto. Vértex convexo, apresentando um par de espinhos lateralmente orientados de aparência rugosa, densamente tuberculado, com margens lobadas irregularmente e ápice terminando em uma ponta aguda (Figuras 51, 58). Olhos compostos relativamente pequenos, redondos, projetando-se lateralmente e levemente orientados anteriormente. Palpos labiais e maxilares robustos, com segmentos terminais ovalados e arredondados (Figura 51). Antena filiforme, com cerca de vinte e dois a vinte e cinco antenômeros; apresentando pequenas cerdas por toda sua extensão, porém concentradas principalmente nas nos vértices, alcançando o segmento abdominal IV-V quando estendidos posteriormente. Escapo liso, levemente mais longo do que largo, achatado dorsoventralmente; pedicelo sub cilíndrico, com mais da metade do tamanho de comprimento do escapo. Primeiro flagelômero triangular em seção transversal. Órgão antenal conspícuo, amarelado, largo, presente na margem dorsal posterior do décimo segundo antenômero.

Tórax (Figuras 50-53, 58-59). Protórax subquadrado em seção transversal, meso- e metatórax sub-cilíndricos. Pronoto densamente tuberculado, rugoso, com sulcos profundos, sub-retangular em vista dorsal, levemente elevado posteriormente, cerca de 1.1x mais longo do que largo, apresentando dorsalmente um par de espinhos medianos posicionados logo antes da sutura mediana, além de um par de espinhos maiores posteriores. Mesotórax rugoso, tuberculado, cerca de 3,4x maior que o protórax, apresentando dorsalmente alguns espinhos paramedianos assimétricos. Ao menos um par localizado próximo a margem posterior, e um par de ornamentações foliáceas e lanceoladas, irregulares, rugosas, tuberculadas e achatadas dorsoventralmente dispostas lateralmente, com ápice terminando em uma ponta aguda (Figuras 50, 52, 53 e 58), além de dois pares menores de espinhos cônicos dispostos anterior e posteriormente. Metatórax e segmento mediano rugosos, tuberculados (Figuras 50, 52, 53 e 58); metatórax, cerca de 2.4x mais longos que o segmento mediano; mesotórax cerca de $1.42 \mathrm{x}$ mais longo que o metatórax e o segmento mediano combinados. Metatórax apresentando centralmente um par de ornamentações foliáceas orientadas lateralmente similares às presentes no mesotórax, apresentando um par de espinhos cônicos na divisão entre o metatórax e o segmento mediano. Meso- and metaepimero projetando-se além dos respectivos segmentos, mesoepimero curto; coxopleurito irregular, tuberculado; meso- e metaepisterno projetados lateralmente como um lóbulo irregular com um espinho apical (Figura 53).

Pernas (Figuras 50-52, 58). Pernas posteriores ultrapassando o final do segmento abdominal $\mathrm{X}$ quando estendidas posteriormente. Fêmures carenados e tuberculados, apresentando espinhos cônicos e projeções foliáceas e fracamente tuberculados na carena 
ventral. Meso- e metafêmur apresentando lóbulos rugosos distintos de variados tamanhos tanto nas carenas dorsais quanto ventrolaterais. Tíbia com com carenas pouco proeminentes e pouco tuberculada.

Abdômen (Figuras 50, 54, 58). Como no gênero. Segmentos II-VII com uma constrição central suave. Tergitos II e III apresentando um par de espinhos bem desenvolvidos em sua margem posterior; IV apresenta um par mais curto shorter pair; V normalmente apresenta um lóbulo transversal em sua margem posterior, levemente inclinado posteriormente; VI apresente uma escama lobada mediana larga, bem desenvolvida, inclinada no sentido posterior do abdômen e ultrapassando a margem anterior do segmento abdominal VII. Tergito $\mathrm{X}$ irregular, quilhado, rugoso, com sua margem posterior alargada e lobada de forma irregular. (Figura 54). Placa subgenital elíptica, com margem posterior arredondada (Figura 54), ultrapassando levemente a margem do tergito X; apresentando um quilha nos dois terços da porção anterior, tuberculada de forma mais intensa a partir de sua porção mediana. Orgão pré opercular distintamente proeminente, escurecido, rugoso, de formato globoso e irregular, sendo delimitado anteriormente por quilhas em formato de $\mathrm{V}$ invertido, com projeções laterais bem desenvolvidas. (Figura 54).

Variação: Algumas fêmeas podem apresentar mais ornamentações pelo corpo e tíbias, dentre elas espinhos, lóbulos e quilhas (Figuras 53), incluindo o episterno (Figura 53).

\section{Descrição do macho (Figuras 50-52, 55-56, 59)}

Bicho-pau áptero, fino e espinhoso, com uma sutil linha mediana dorsal preta.

Coloração (Figuras 50-52, 55, 59). Como o gênero, o corpo varia em tons de bege, marrom claro ou acastanhado, normalmente em tons mais claros que as fêmeas. Meta- e mesotórax, junto com o segmento mediano e tergitos II e III apresentam uma conspícua linha preta longitudinal. Cabeça apresentando diferentes tons de marrom claro, escuro e bege, com uma linha longitudinal lateral percorrendo da margem posterior da cabeça até atrás dos olhos. Olhos amarelados. Antenas marrom claro dorsalmente, escurecidas ventralmente. Pernas normalmente são rajadas ou manchadas em tons mais escuros de marrom, incluindo os tarsômeros, com a porção anterior do pro-, meso- e metafêmur esverdeados, como nas fêmeas. Tubérculos e espinhos completamente beges, marrons ou pretos, apresentando pontas mais claras em tons de amarelo e laranja; ornamentações torácicas lobadas seguem o padrão de coloração do corpo, mais claras dorsalmente e escurecidas ventralmente.

Cabeça (Figuras 50-51). Como para o gênero, levemente alongada e tuberculada. Ovóide em vista dorsal, cerca de 1.1x mais longa que larga, com cerca do mesmo comprimento do pronoto.Vertex gentilmente convexo com um par de espinhos lateralmente 
orientados. Olhos como o gênero. Palpos labiais e maxilares como o gênero (Figura 51). Antena filiforme como no gênero, variando de vinte e dois a vinte e cinco antenômeros; apresentando cerdas em toda a sua superfície e chegando ao segmento abdominal X quando estendida posteriormente. Escapo liso, como no gênero; pedicelo sub cilíndrico, com mais da metade do tamanho do escapo. Órgão antenal conspícuo, levemente menor que o da fêmea, presente na margem posterior dorsal do décimo terceiro antenômero.

Tórax (Figuras 50-52). Protórax subquadrado em seção transversal, meso- e metatórax sub-cilíndricos. Pronoto tuberculado, com sulcos profundos, sub-retangular em vista dorsal.=, em formato de sela, posteriormente elevado, cerca de 1.1 mais longo do que largo. Apresenta dorsalmente um par de pequenos espinhos medianos logo antes da sutura mediana e ou outro par de espinhos maiores e mais robustos na margem posterior, assim como nas fêmeas. Mesotórax liso, cerca de 3,9x mais longo do que o protórax, tuberculado lateral e dorsalmente e apresentando ao menos um par de espinhos assimétricos próximos à margem anterior, um par simétrico na margem posterior e um par de espinhos cônicos, dorso-ventralmente achatados e lateralmente orientados em sua porção mediana. Metatórax e segmento mediano tuberculados como no metatórax (Figura 52); metatórax cerca de 3x mais longo que o segmento mediano, mesotórax cerca de $1.3 \mathrm{x}$ mais longo que o metatórax e segmento medianos combinados. Metatórax apresentando em sua porção central um par de espinhos cônicos achatados dorsoventralmente e lateralmente orientados como no mesotórax, além de um par de espinhos cônicos menores e bem desenvolvidos na divisão entre o metatórax e o segmento mediano. Meso- e metaepímero se projetando além de seus respectivos segmentos, mesoepímero curto; coxopleurito irregular, tuberculado; meso- e metaepisterno projetados lateralmente como lóbulos irregulares, com espinhos apicais conferindo uma aparência serrilhada.

Pernas (Figura 50-52). Como no gênero. Fêmures apresentam todas as carenas levemente quilhadas, tuberculadas e apresentando projeções em formato de lóbulos ou espinhos cônicos. Meso- e metafêmur apresentando ornamentações como nas fêmeas, porém de forma mais discreta e irregular. Tíbia como no gênero, com leve carenas e tuberculadas. Basitarsos com cerca do mesmo tamanho de todos os outros tarsômeros combinados.

Abdômen (Figuras 50, 55-56). Como no gênero, distintamente tuberculado, levemente rugoso até sua metade posterior. Segmentos II-VII mais longos que largos, VIII-IX mais largos que longos, $\mathrm{X}$ tão longo quanto largo. Segmentos gradualmente diminuindo de tamanho entre os segmentos VI a IX. Segmentos II-VIII com uma constrição central, gradualmente se intensificando nos segmentos mais posteriores. Tergitos II e III apresentam um par de espinhos próximos à margem posterior; tergito VIII alargado 
consideravelmente em sua porção posterior. Tergitos VIII-X com uma carena contínua conspícua central e duas paramedianas. Tergitos VII-IX com uma margem posterior elevada e arredondada. Tergito $\mathrm{X}$ cerca de $1.3 \mathrm{x}$ mais longo que o IX; Com margem posterior distintamente emarginada (Figura 55), formando dois lóbulos laterais, cada qual apresentando uma placa dentada com pequenos espinhos curtos, robustos e curvos (Figura 55). Esternito VIII mais curto que o tergito correspondente, mais largo que longo e apresentando posteriormente duas quilhas projetadas paramedianamente. Esternito IX formando um póculo de formato distinto, côncavo, similar a uma xícara (Figura 55); região ventral com uma carena mediana conspícua se estendendo à uma confluência posterior aguda, com margem fortemente esclerotizada. Paraprocto curto, curvado internamente, epiprocto quilhado, largo e triangular. Cercos afunilando apicalmente e achatados dorsoventralmente (Figura 55).

Genitália (Figura 56): Esclerito dorsal tendo origem do lado direito da estrutura da genitália quando em vista dorsal. Tem formato irregular, com a margem posterior terminando diagonalmente oposta a sua origem e apresentando um prolongamento em sua margem orientado ventralmente, onde o lóbulo dorsal está associado. O lóbulo dorsal membranoso, largo. A membrana basal do esclerito interno é cilíndrica, normalmente envolvendo o esclerito interno dentro da estrutura da genitália, oculta pelo lóbulo dorsal, o lóbulo sinuoso ventral e o lóbulo basal. A porção apical do lóbulo sinuoso, porção apical do lóbulo basal e projeção bífida são bem esclerotizadas. A projeção bífida está localizada do lado direito da genitália quando observada frontalmente. A membrana basal do esclerito interno é eversível, formando uma estrutura membranosa cilíndrica que acomoda em sua porção apical o apódema basal, discreto e em formato de escama, e o esclerito interno em formato de gancho, fortemente esclerotizado e assimétrico, curvado para a esquerda. A ponta do esclerito interno é arredondada, quase em formato de gota e não possui nenhum tipo de ornamentação ao longo da estrutura.

\section{Descrição dos ovos (Figura 57)}

De coloração amarronzada, podendo variar entre tons mais claros e escuros. Com formato de barril, levemente côncavos dorsalmente, cerca de 1.6x mais longos do que largos. Superfície com cristas reticuladas distintas, robustas e grossas, com disposição circular na margem opercular. Cristas irregulares, se tornando arredondadas e mais elevadas em intersecções, sendo internamente porosas e esparsamente perfuradas em sua superfície. As cristas circundam aperturas levemente côncavas, brilhantes, de tamanho variado, normalmente arredondadas ou elípticas. Opérculo circular, com superfície similar ao resto da cápsula do ovo, apresentando as mesmas cristas e aberturas. Micrópila com uma linha mediana distinta, 
se estendendo da margem posterior da placa micropilar até sua base, percorrendo cerca de $2 / 5$ do seu comprimento. Placa micropilar externa distinta, depressa, arredondada, com superfície brilhante e rugosa, com uma leve elevação enrugada do poro micropilar no meio da placa. Poro micropilar escurecido, anteriormente convexo. Linha mediana contínua com as margens da placa micropilar, elevadas formando um margem rugosa e irregular, mais fina e clara que as cristas da cápsula do ovo, porém externamente conectadas.

Ninfas (Figura 59)

Ninfas de primeiro instar verde claro com tarsômeros, antenômeros II a IX (excluindo escapo) e extremidade posterior da tíbia marrom escuro. porção final dos antenômeros IX a X brancos. Olhos dourados ou acastanhados. Cabeça apresentando uma faixa lateral escurecida iniciando na base do escapo e percorrendo até o fim da cabeça. Terminália não diferenciada a olho nu. Cabeça, tarsos e cercos relativamente maiores do que nos adultos e estágios mais tardios da fase ninfal. Segmento mediano menor que o metanoto. Segmento anal e epiprocto levemente lanceolados. Carenas femorais quilhadas. A partir do terceiro instar, ninfas apresentam lóbulos e espinhos na cabeça, tórax, abdômen e pernas, similar ao adultos, gradualmente ficando maiores, mais proeminentes e de tamanho similar a ornamentação encontrada em adultos nos estágios mais tardios. Machos são significativamente menos ornamentados e apresentam estruturas menores que as fềmeas de mesmo ínstar. Também não possuem lóbulos abdominais, e os lóbulos torácicos começam a se desenvolver apenas entre o quarto e quinto instar.

Distribuição. Ceroys (Miroceroys) sp. nov. é conhecido apenas para a região Sudeste da Serra da Mantiqueira, nos municípios de Extrema e Camanducaia, no Estado de Minas Gerais, Brasil. Ocorre em altitudes entre 1400-1700 metros, em vegetação de Mata Atlântica caracterizada como floresta ombrófila, submontana ou montana. Espécimes encontrados em Camanducaia, no distrito de Monte Verde, foram coletados na Trilha do Jorge próximos a um córrego a cerca de 1400-1500 metros acima do nível do mar. Em ambos os casos onde foram encontrados, espécimes estavam forrageando no solo ou em vegetação arbustiva. É possível que a distribuição da espécie seja mais ampla, ocorrendo em outras partes da Serra da Mantiqueira.

Comentários: Dado o acesso ao material tipo de todas as espécies tipo obtidas durante a realização deste trabalho e a presença de espécimes referentes a todas as espécies previamente descritas no MZUSP foi possível a identificação dos indivíduos de Ceroys (Miroceroys) sp. nov. como uma espécie previamente desconhecida. 
> Material Examinado 1q(MZSP \#1184): Brasil, MG, Extrema. 2252’42.4”S, 46 ${ }^{\circ} 18^{\prime} 53.9^{\prime \prime W}$. 1450m de alt. Kamakuza, S. H., Engelking, P. W., Crispino, E. B. e Ghirotto, V. M. coll.. 30.III.2018; 1 (MZSP \#1186) 4ð(MZSP \#1183, \#1185, 1187, 1230): Brasil, MG, Extrema. 2252'42.4”S, 46¹8'53.9”W. 1450m de alt. Kamakuza, S. H., Engelking, P. W., Crispino, E. B. e Ghirotto, V. M. coll. 30.III.2018; 1 (MZSP \#376): Brasil, MG, Monte Verde. 22 $2^{\circ} 2^{\prime} 08^{\prime \prime S}, 46^{\circ} 01^{\prime} 04^{\prime \prime}$ W. 20.IV.2015. P. I. Chiquetto-Machado \& A. Z. Ramin coll;

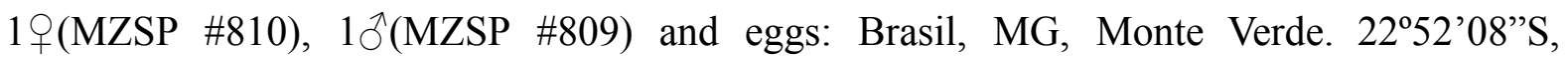
4601'04”W. 7.I.2017. P. I. Chiquetto-Machado \& A. Z. Ramin coll.

\subsection{Biologia}

Espécies do gênero Ceroys são comumente encontradas associadas à vegetação arbustiva de áreas úmidas e bem conservadas de M.A. As espécies, como a maioria dos Phasmatodea, apresentam hábitos noturnos. Durante o dia ficam imóveis, usualmente com o primeiro par de pernas esticado escondendo parcialmente a cabeça e antenas. O tórax e/ou abdômen costumam ficar curvados em relação ao substrato, dando a impressão que são parte de um ramo quebrado, matéria vegetal ou musgo associados ao folhiço, serapilheira, cascas de árvores, vegetação rasteira, galhos, etc. São particularmente móveis no período noturno, ativamente forrageando por alimento, água e parceiros para se acasalar. Ao menos duas espécies do gênero já foram observadas ativamente mudando de cor ao longo do dia de acordo com níveis de iluminação do ambiente e, possivelmente, umidade (Figuras 21 e 39).

De hábito polífago, costumam ser vistos alimentando-se de samambaias variadas, Melastomatacea (Tibouchina mutabilis), Myrtaceae (Psidium guajava e Eugenia uniflora), Onagraceae (Ludwigia sp.), Rosacea (Rubus sp. e Rosa sp.) e Piperaceae variadas (especialmente Piper umbellatum).

Machos são comumente avistados "cavalgando" fêmeas por longos períodos de tempo, apoiando suas pernas na ornamentação e pernas da fêmea e utilizando o vômer para segurar o órgão pré opercular. O comportamento é possivelmente uma estratégia para evitar que diferentes machos copulem com a mesma fêmea. Não é conhecido nenhuma forma de embate entre machos durante a fase de reprodução, como já observado para algumas espécies (Sivinski, 1978). Fêmeas no geral costumam dispersar ovos maduros no ambiente movimentando o abdômen de forma abrupta para lançá-los no ambiente ou simplesmente relaxando a estrutura do ovipositor e deixando que caiam no substrato. Apesar disso, ao menos uma espécie do gênero, Ceroys (Miroceroys) saevissimus Wetwood, 1859, costuma enterrar os ovos em cascas, solo e serrapilheira. É desconhecida a ocorrência de 
partenogênese facultativa nas espécies do gênero.

Todas as espécies do gênero se mostraram particularmente sensíveis a ambientes que não condizem com os parâmetros de umidade do local onde foram encontrados. Em cativeiro, níveis prolongados de umidade abaixo de $80 \%$ e sem boa ventilação se mostraram fatais para todos os indivíduos, que morrem em menos de uma semana. Mesmo sob cuidado intenso, a flutuação constante de parâmetros de umidade e a não disponibilidade de gotículas de água suspensas no ambiente para hidratação mostra-se fatal para indivíduos adultos, que sobrevivem pouco mais de 3 semanas. Os ovos são de difícil eclosão, necessitando de muita umidade para seu desenvolvimento correto. Ninfas são ainda mais sensíveis que adultos, morrendo em questão de horas se expostas a níveis de umidade abaixo de $80 \%$.

\subsection{Comentários sobre o Gênero}

O nome Ceroys deriva do grego Képas (Kéras) = Corno, chifre e Ovৎ (Oûs) = Orelha. O nome se dá em virtude da ornamentação presente na cabeça de ambos os sexos, espinhos inclinados lateralmente que normalmente apresentam algum grau de compressão e achatamento dorsoventral. Curiosamente, este mesmo padrão de ornamentação é visto em vários outros gêneros de Heteronemiidae como Canuleius e Pygirhynchus, de Diapheromeridae como Exocnophila Zompro, 2001 e Libethra Stål, 1875 e em Pseudophasmatidae em representantes da tribo Xerosomatini. Já o nome Miroceroys deriva

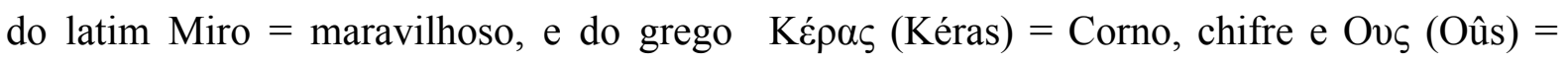
Orelha. O nome é a combinação do nome dos gêneros Mirophasma e Ceroys, dado que na opinião de Piza (1936) o gênero apresentava a ornamentação do primeiro e morfologia do segundo

\section{4 - DISCUSSÃO}

\subsection{Caracterização das espécies de Ceroys de Mata Atlântica}

A análise morfológica possibilitou caracterizar e delimitar com segurança todas as espécies originalmente descritas para o gênero no território da Mata Atlântica, além de evidenciar a presença de ao menos uma espécie previamente desconhecida. Os resultados mostram também que dentre o conjunto inicial das dez espécies selecionadas para o estudo, quatro são sinonímias e uma pertence a outro gênero. O resultado final é uma diminuição de $50 \%$ da quantidade de espécies descritas para Ceroys na Mata Atlântica. As sinonímias identificadas neste estudo são referentes a espécimes jovens e/ou sexos descritos como 
espécies distintas, refletindo o prévio estado de desconhecimento do gênero e falta de estudos aprofundados com o grupo.

O material analisado apresenta alto grau de similaridade morfológica entre as diferentes espécies: padrões de ornamentação e morfologia externa são relativamente conservados e compartilhados por diversas espécies, com poucos caracteres externos não plásticos que auxiliem na identificação. A diferenciação, originalmente considerando apenas a morfologia externa, se dá por pequenas variações de coloração entre indivíduos, padrões subjetivos de quantidade de espinhos e tubérculos, presença ou ausência de escamas e lamelas em diferentes partes do corpo e seu grau de desenvolvimento, dentre outros. Identificar entre essas características qual é diagnóstica e qual é uma variação morfológica intraespecífica plástica não informativa e/ou compartilhada entre diferentes espécies era um desafio que até então nunca havia sido de fato explorado, e que só foi solucionado após a análise de outros caracteres de relevante importância taxonômica: ovos, estruturas da terminália feminina e genitália masculina.

Os ovos de Ceroys apresentam uma morfologia única entre os demais Pygirhynchini: Sua cápsula é intrincadamente ornamentada com padrões geométricos bem pronunciados, criando uma espécie de malha e conferindo ao ovo a aparência similar a um vitral ou mosaico não observada até o momento em nenhum outro representante da tribo. Não apresentam cerdas como em Canuleius (Crispino et. al. 2020, Ghirotto 2021) e Pygirhynchus (com base em material complementar depositado na coleção do MZUSP), são mais encorpados e sua placa micropilar é mais arredondada. Apesar de apresentarem poucas variações que auxiliem a diferenciar entre espécies (exceção é Ceroys (Miroceroys) saevissimus.) a anatomia geral ajudou e identificar prontamente a classificação errônea de Canuleius scaber em Ceroys apesar da similaridade da morfologia externa do holótipo com indivíduos fêmea de Ceroys (Ceroys) perfoliatus.

Da mesma forma, a genitália de todas as espécies analisadas apresentam diferenças expressivas que permitem sua delimitação. Não só é possível diferenciá-las baseado em sua anatomia, como seu estudo permitiu também a identificação de possíveis equívocos taxonômicos. Espécimes de Canuleius euterpinus (Westwood, 1859) são comumente agrupados em coleções com fêmeas adultas de Ceroys (Ceroys) perfoliatus, possivelmente indicando que sejam um casal da mesma espécie. Essa classificação, considerada por alguns autores como correta (Vallero, Neves e Ghirotto, comunicação pessoal), resultaria na sinonimização de Canuleius Stål, 1875 com Ceroys, uma vez que Canuleius euterpinus é a espécie tipo do gênero. Isso resultaria em todo um rearranjo das espécies em ao menos um ou mais novos gêneros para acomodar as espécies previamente classificadas em Canuleius. A 
análise detalhada de Canuleius euterpinus, no entanto, evidenciou não apenas diferenças expressivas na morfologia da espécie em relação aos demais Ceroys, quanto também a similaridade de sua genitália com demais espécies de Canuleius: o esclerito interno é pequeno e curvado, em formato de gancho, estando associado com um lóbulo dorsal localizado entre o esclerito dorsal e o lóbulo sinuoso, o lóbulo basal e projeção bífida. Essa característica é compartilhada por todas as espécies de Canuleius analisadas (Canuleius grandis Piza 1936, Canuleius sanguinolentus (Brunner von Wattenwyl, 1907), Canuleius scaber Piza 1936 e Canuleius similis Redtenbacher, 1906).

\subsection{Situação e validade dos Subgêneros Ceroys e Miroceroys}

Criado por Piza (1936), o subgênero Miroceroys diferencia-se em relação à Ceroys exclusivamente pelo seu padrão de ornamentação, levando o autor a nomeá-lo referenciando suas similaridades com Mirophasma Redtenbacher, 1906. No entanto, se excluirmos a ornamentação (já mencionada como uma característica pouco informativa), as espécies presentes no subgênero são anatomicamente similares às presentes no subgênero Ceroys. A anatomia geral do ovo, estruturas da genitália e anatomia dos componentes do aparato do ovipositor da fêmea apresentam grande similaridade, colocando em cheque a justificativa da separação das espécies em dois subgêneros. A dubiedade da questão é perfeitamente ilustrada pela espécie altamente ornamentada Ceroys (Ceroys) cristatus, descrita por Redtenbacher (1906). Apesar de visualmente apresentar o semblante de um Miroceroys, o autor comenta em sua descrição original o quão similar a espécie é a Ceroys (Ceroys) perfoliatus, a espécie tipo do gênero, diferindo apenas pela ornamentação. Em sua visão, a ornamentação apresentada pela espécie não justificaria a criação ou separação em um novo gênero. Dessa forma, o correto seria a separação dos subgêneros, a revalidação de Miroceroys como um gênero ou a sinonímia?

Apesar dos dados obtidos neste estudo tanto de morfologia geral externa quanto de análise de ovo, terminália e genitália apontarem em direção a uma possível sinonímia entre os subgêneros, a resolução dessa situação requer que dois tópicos extremamente importantes sejam abordados: sinonímia à revelia de análises filogenéticas e a situação dos demais gêneros da tribo.

No primeiro caso, novos gêneros, tribos e até mesmo famílias são continuamente criadas e/ou sinonimizadas em Phasmatodea baseadas em revisões superficiais de morfologia externa sem ao menos uma análise filogenética morfológica (Zompro 2001, 2004a,b,). O resultado é a criação de grupos artificiais baseados em caracteres não informativos, como as 
subordens Areolatae e Anareolatae com base na presença ou ausência de area apicalis ou a separação de Heteronemiidae e Diapheromeridae (Zompro 2001, 2004a,b), a descrição de táxons "exóticos" para o território nacional e a possibilidade do agrupamento artificial de espécies de anatomia convergentes porém não relacionadas. Esse último caso é ilustrado pela descrição de Candovia evoneobertii (Zompro \& Adis, 2001) e Echetlus fulgens Zompro, 2004, para o Brasil como “espécies introduzidas" (Brock \& Hasenpusch 2009, Brock et al. 2021). Ambos os gêneros são encontrados apenas no Velho Mundo e pertencem a famílias distintas (Lochondidae e Phasmatidae, respectivamente). As espécies descritas para o território nacional são na verdade relacionadas ao gênero Phantasca Redtenbacher, 1906, da família Diapheromeridae (Girotto et al. submetido). O refinamento e aprofundamento de análises morfológicas, especialmente quando atentas a variações intraespecíficas (Gutiérrez-Valencia et al. 2017, Crispino et al. 2020, Ghirotto 2021, Chiquetto-Machado \& Cancello 2021) e uso de outros caracteres além dos tradicionalmente utilizados é essencial para evitar situações similares e ainda prevalecentes na ordem, como demonstrado em um dos estudos mais recentes para Phasmatodea neotropicais sobre o gênero Paraphasma Redtenbacher, 1906 (Chiquetto-Machado \& Cancello, 2021). O trabalho mencionado também indicou a presença de espécies pertencentes a outros gêneros classificadas em Paraphasma, situação que é possivelmente compartilhada por ao menos Ceroys (Ceroys) cristatus. A espécie é considerada por alguns como pertencente ao subgênero Miroceroys (Pablo Vallero, comunicação pessoal) por conta da sua anatomia externa, mas os resultados da análise indicam que ela na verdade possa estar mais relacionada a algumas espécies classificadas atualmente em Pygirhynchus.

Dessa forma, a melhor forma de resolver o debate sobre os subgêneros Ceroys e Miroceroys é a realização de uma análise integrada envolvendo todos os gêneros envolvidos, senão todos da tribo. Portanto, apesar das evidências morfológicas apontarem para uma sinonímia entre os subgêneros, a decisão não só foge do escopo original deste trabalho como requer análises complementares que serão feitas posteriormente. Além disso, Pygirhynchus, o segundo ponto de interesse mencionado e essencial para a realização das análises filogenéticas mencionadas, encontra-se numa situação taxonômica delicada.

\subsection{Comparação e implicações quanto a Pygirhyncus Audinet-Serville 1838}

Tanto Pygirhynchus quanto Ceroys apresentam um elevado grau de convergência morfológica, sendo originalmente diferenciados pelo alongamento da porção distal da placa subgenital e tergito abdominal $\mathrm{X}$ das fêmeas formando uma estrutura para inserção dos ovos 
no substrato. Zompro (2004a) também menciona que podem ser diferenciados das fêmeas de Ceroys ao se analisar o tórax em seção transversal, apresentando um formato pentagonal. Com exceção dessas características, fêmeas e machos apresentam uma morfologia corporal similar entre ambos os gêneros. Tais características não são exclusivas do gênero, sendo observadas em Ceroys (Miroceroys) saevissimus e estando ausentes de Pygirhynchus toledopizai Zompro 2004. O formato do tórax também é um artefato relativamente comum durante o processo de secagem de espécimes da tribo: a presença de uma quilha dorsal mediana bem pronunciada é presente em apenas algumas fêmeas vivas de algumas espécies de ambos os gêneros.

A situação fica ainda mais complicada quando consideramos que o holótipo da espécie tipo do gênero, Pygirhynchus subfoliatus Audinet-Serville 1838, uma fêmea, está perdida. A descrição original de Audinet-Serville, no entanto, sugere que Pygirhynchus vigilans (Westwood, 1859) seja sinônimo de Pygirhynchus subfoliatus. Mais estudos são necessários para confirmar essa diagnose. De toda forma, análises do material referente ao gênero depositado nas coleções considerando anatomia externa, ovo, genitália masculina e estruturas do ovipositor feminino indicam três morfogrupos distintos dentro de Pygirhynchus: um com estruturas do ovipositor e morfologia do ovo similar aos observados em Ceroys (não haviam machos desses exemplares nas coleções), um segundo grupo com morfologia de ovipositor, genitália masculina e ovos como em Ceroys (Ceroys) cristatus, Pygirhynchus toledopizai e outras espécies não identificadas e um terceiro grupo com genitália, ovipositor e anatomia do ovo vistas apenas entre espécies descritas em Pygirhynchus e similares a Pygirhynchus vigilans. Além disso, os caracteres diagnósticos do gênero, a placa subgenital e tergito $\mathrm{X}$ alongados, estão presentes em algumas espécies dos três morfogrupos.

Dessa forma é possível que dentro de Pygirhynchus existam espécies pertencentes a três gêneros distintos, sejam eles existentes e possivelmente novos. A perda do material tipo, porém, torna a caracterização dos grupos extremamente complicada. Só através de um estudo aprofundado e detalhado do grupo e análise minuciosa de material histórico depositado em instituições estrangeiras que será possível resolver a questão de identidade do gênero e, consequentemente, gêneros relacionados.

\subsection{Um gênero exclusivo da Mata Atlântica?}

A delimitação das espécies do gênero nos permite chegar mais próximos de elucidar a real distribuição de Ceroys. Originalmente listado para diferentes territórios da América do Sul (Tabela 1), o gênero se encontra hoje com apenas três espécies localizadas fora do 
território nacional, enquanto as demais se concentram em regiões do Sul e Sudeste Brasileiro. Espécimes depositados nas coleções analisadas estão associadas a vegetação de Mata Atlântica ou fragmentos de vegetação transicional entre a M.A. e o Cerrado. Os registros presentes no iNaturalist, totalizando mais de 6 mil avistamentos de Phasmatodea para a América do Sul e analisados durante a realização do estudo pelo autor e pesquisadores da área, não apresentam registros de Ceroys para qualquer outro bioma ou região do continente senão regiões de M.A. do Sudeste.

No caso das espécies listadas para fora do Brasil, Ceroys (Ceroys) brevicornis Conle, Hennemann \& Gutiérrez, 2011 está alocado temporariamente no gênero enquanto mais material referente a espécie não é descrito, Ceroys (Ceroys) pusillus Redtenbacher, 1906 não pertence ao gênero (Pablo Vallero, comunicação pessoal) sendo muito similar em anatomia e proporções corporais a espécies relacionadas a Mirophasma e Parobrimus Scudder, 1896 (Pseudophasmatidae: Xerosomatianae: Xerosomatini) e análises envolvendo Ceroys (Ceroys) lituus Rehn, 1906 são prejudicadas pela perda do holótipo.

De forma similar, as espécies brasileiras apresentam distribuição relativamente restrita e baixa sobreposição de áreas de distribuição (Figura 63), possivelmente indicando áreas de distribuição bem delimitadas e restritas. Apesar de serem espécies relativamente ativas e móveis, indivíduos do gênero costumam ser encontrados apenas em ambientes com vegetação bem conservada e elevados níveis de umidade do ar. Variações ambientais, sejam por mudança de fitofisionomia por conta da transição de ecossistemas ou por degradação humana, podem ser fatores importantes na delimitação de áreas de ocorrência dessas espécies.

É seguro dizer então que Ceroys possivelmente é um gênero exclusivo da Mata Atlântica, apesar que uma resposta conclusiva sobre a distribuição do gênero e gêneros relacionados nos Neotrópicos só será respondida com a elucidação da situação taxonômica das espécies previamente mencionadas e coleta de mais material, especialmente de regiões adjacentes à Mata Atlântica e localidades historicamente associadas com a ocorrência da espécie.

\subsection{A Situação de Heteronemiidae}

A família Heteronemiidae, como mencionada anteriormente, é baseada numa separação de Diapheromeridae resultando na dissociação de grupos de espécies com bases em caracteres artificiais. Isso apresenta dois problemas: a separação em dois grupos sabidamente artificiais e a validação de Diapheromeridae em seu estado polifilético, englobando duas ou 
mais famílias de táxons não relacionados (Bradler 2009). Não obstante, há uma sobreposição de espécies, gêneros e famílias descritas ao mesmo tempo para Heteronemiidae, Diapheromeridae e Phasmatidae (Hennemann et al. 2016), dada a caracterização superficial dos táxons, convergências morfológicas, polimorfias intraespecíficas e similaridade de nichos (Henneman et al. 2016, Gutiérrez-Valencia et al. 2017, Crispino et al. 2020). A soma destes problemas e a ausência de trabalhos com Heteronemiidae resultam na sub-representação ou ausência da família nos principais estudos filogenéticos recentes (Robertson et al. 2018, Simon et al. 2019, Tihelka et al. 2020, Forni et al. 2021), resultando em um posicionamento dúbio. O mais plausível é que Heteronemiidae componha o grupo dos bichos-pau neotropicais Occidophasmata junto de Pseudophasmatidae, Prisopodidae, os Diapheromeridae e parte de Phasmatidae (Simon et al. 2019).

A situação é fruto do trabalho de Zompro no começo dos anos 2000. Suas publicações entre na virada do milênio (Zompro 2001 a, b; 2004 a, b; Zompro \& Adis 2001) são um marco importante para o estudo de espécies de Phasmatodea do Novo Mundo, mas apresentam limitações importantes: chaves de identificação com passos inalcançáveis, espécimes com sexagem e identificação de estruturas corporais errôneas, transferências com base em caracterizações vagas sem análises aprofundadas e caracteres não diagnósticos, construções de árvores filogenéticas sem princípios sistemáticos, entre outros (Zompro 2004b, Hennemann \& Conle 2010, Hennemann et al. 2016). Apesar de estudos recentes com a família (Crispino et al. 2020, Ghirotto 2021) levantarem características importantes para a delimitação da tribo Pygirhynchini, não há informação suficiente sobre seus representantes para uma delimitação sólida do grupo. Estudos urgentes são necessários com Heteronemia Gray, 1835: De forma similar a feita com Bacteria Berthold, 1827, Zompro revisou o gênero e "validou" a espécie tipo do gênero, Heteronemia mexicana Gray, 1835 (zompro 2001a,b). As demais espécies, de acordo com o autor, "pertencem a outros gêneros e possivelmente famílias mas foram mantidas provisoriamente no gênero". Apesar de não ser improvável que existam diversas sinonímias e espécies erroneamente classificadas em Heteronemia, o estado atual contribui mais para que o grupo como um todo seja desconsiderado de estudos do que atraia interesse para a resolução de seus problemas.

Ainda assim, os caracteres anatômicos do ovo, especialmente a placa micropilar ovalada localizada medianamente no ovo, as margens da placa micropilar desenvolvidas e proeminentes, a placa micropilar interna fechada e a ausência de capítulo parecem ser uma das poucas diagnoses para identificar com confiança representantes da família. A anatomia geral Heteronemia mexicana parece ser também constante entre os representantes da família, porém só estudos aprofundados com ênfase em um leque mais diverso e de caracteres 
morfológicos indicará a posição e relacionamento dos diferentes grupos intra familiares, bem como a posição da família dentre os demais Phasmatodea.

\section{5 - CONCLUSÃO}

Das dez espécies de Ceroys originalmente descritas para a Mata Atlântica (Tabela 1) e analisadas neste estudo apenas quatro são consideradas válidas: Ceroys (Ceroys) perfoliatus, Ceroys (Ceroys) cristatus, Ceroys (Miroceroys) heymonsi e Ceroys (Miroceroys) saevissimus. Ceroys scaber é transferida para Canuleius e redescrita, enquanto Ceroys (Ceroys) albogranulatus syn. nov., Ceroys (Ceroys) multispinosum syn. nov., Ceroys (Ceroys) spinosus syn. nov. (todas sinônimas de C. perfoliatus), Ceroys (Miroceroys) brunneri syn. nov. (sinônimo de C. cristatus) e Ceroys (Miroceroys) redtenbacheri syn. nov. (sinônimo de C. saevissimus) são sinonimizadas. Uma nova espécie, Ceroys (Miroceroys) sp. nov., a quinta para o gênero, é descrita. Os resultados obtidos, apesar de permitirem a caracterização e identificação das espécies presentes no estudo, também levantam mais perguntas quanto ao monofiletismo do gênero Ceroys e a delicada situação em que Heteronemiidae se encontra. A análise morfológica de características da genitália, terminália e ovos, bem como seu ciclo de vida e biologia das espécies, permitiram a delimitação dos táxons estudados e a resolução de problemas de classificação envolvendo um dos gêneros menos estudados em Phasmatodea. Em contrapartida, os resultados levantam ainda mais questões sobre a identidade do gênero Ceroys, Pygirhynchus e grupos relacionados: A presença de três subgrupos morfológicos parecem não sustentar a existência dos subgêneros de Ceroys, muito menos a validade de Miroceroys como originalmente descrito por Piza. Além disso, a perda do holótipo da espécie tipo de Pygirhynchus torna sua caracterização um potencial problema para a delimitação de Ceroys: ele é a chave para a validação ou sinonimização de Pygirhynchus, bem como da potencial criação de um novo gênero. Tais conclusões só poderão ser de fato confirmadas após mais estudos abrangentes envolvendo análises filogenéticas com base na morfologia e análises genéticas de táxons dos três subgrupos delimitados nesta dissertação, seguindo os padrões de estudos recentes envolvendo a ordem.

De toda forma, os resultados aqui apresentados são até o momento um dos poucos envolvendo a família Heteronemiidae. A continuidade da linha de pesquisa iniciada por colegas com base em estudos de genitália e anatomia detalhada tem se mostrado extremamente relevante para a resolução de problemas taxonômicos persistentes na ordem, oferecendo uma possível solução para dilemas de classificação que duram mais de um século. Esperamos que este trabalho e os resultados obtidos possam auxiliar para estudos futuros com a ordem, ajudando na pesquisa desses carismáticos porém misteriosos insetos. 


\section{6 - BIBLIOGRAFIA}

Albertoni, F. F., Mielke, C. G., \& Duarte, M. (2018). Saturniid moths (Lepidoptera: Bombycoidea) from an Atlantic Rain Forest fragment in southeastern Brazil. Anais da Academia Brasileira de Ciências, 90, 2827-2844. https://doi.org/10.1590/0001-3765201820170629

Audinet-Serville. J. G. (1831). Revue Méthodique des Insectes de l'ordre des Ortoptères. Annales des Sciences naturelles, Zool. Paris. 22:28-29, 56-65

Audinet-Serville, J. G. (1839). Histoire naturelle des insectes: Orthoptères. (Vol. 1). Roret. $1-776$, pls $1-14$

Baccetti, B. (1987). Spermatozoa and phylogeny in orthopteroid insects. Evolutionary biology of orthopteroid insects, pp: 12-112.

Bedford, G. O. (1978). Biology and ecology of the Phasmatodea. Annual review of entomology, 23(1), 125-149.

Beutel, R. G., \& Gorb, S. N. (2001). Ultrastructure of attachment specializations of hexapods (Arthropoda): evolutionary patterns inferred from a revised ordinal phylogeny. Journal of Zoological Systematics and Evolutionary Research, 39(4), 177-207. https://doi.org/10.1046/j.1439-0469.2001.00155.x

Berthold, A. A. (1827). Latreille's Natürliche Familien des Thierreichs. Aus dem Französischen. mit Anmerkungen und Zusätzen. Verlage Landes-Industrie-Comptoirs, Weimar, 606, 10-5962.

Boudinot, B. E. (2018). A general theory of genital homologies for the Hexapoda (Pancrustacea) derived from skeletomuscular correspondences, with emphasis on the Endopterygota. Arthropod Structure \& Development, 47(6), 563-613. https://doi.org/10.1016/j.asd.2018.11.001

Boudreaux, H. B. (1979). Arthropod phylogeny, with special reference to insects. John Wiley \& Sons, Inc..

Blackith, R. E., \& Blackith, R. M. (1968). A numerical taxonomy of orthopteroid insects. Australian Journal of Zoology, 16(1), 111-131. https://doi.org/10.1071/ZO9680111

Bradler, S. (2003). Phasmatodea, Gespenstschrecken. Lehrbuch der Speziellen Zoologie, 5, 251-261.

Bradler, S. (2009). Die Phylogenie der Stab-und Gespenstschrecken (Insecta: Phasmatodea) (Vol. 2, pp. 1-139). Universitätsverl.

Bradler, S., \& Buckley, T. R. (2018). Biodiversity of phasmatodea. Insect biodiversity: science and society, 2, 281-313. 
Bradler, S., Robertson, J. A., \& Whiting, M. F. (2014). A molecular phylogeny of P hasmatodea with emphasis on Necrosciinae, the most species-rich subfamily of stick insects. Systematic entomology, 39(2), 205-222. https://doi.org/10.1111/syen.12055

Bradley, J. C., \& Galil, B. (1977). The taxonomic arrangement of the Phasmatodea with keys to the subfamilies and tribes. Entomological Society of Washington.

Brock, P. D. (1998). Catalogue of type-specimens of Stick- and Leaf-Insects in the Naturhistorisches Museum Wien (Insecta: Phasmida).

Brock, P. D., Büscher, T. \& Baker, E. (2021). Phasmida Species File Online. Version 5.0/5.0. Disponível em: phasmida.speciesfile.org [acessado em 2 de junho de 2018].

Brock, P. D., \& Hasenpusch, J. W. (2009). The complete field guide to stick and leaf insects of Australia. CSIRO PUBLISHING.

Brown Jr, K. S. (1991). Conservation of neotropical environments: insects as indicators. The conservation of insects and their habitats, 349, 404.

Brown Jr, K. S., \& Brown, G. G. (1992). Habitat alteration and species loss in Brazilian forests. Tropical deforestation and species extinction, 119-142.

Brunner von Wattenwyl, K. (1907). IX. Tribus Clitumnini, X. Tribus Lonchodini, XI. Tribus Bacunculini. Die Insektenfamilie der Phasmiden. Wilhelm Engelmann, Leipzig, 181-338.

Cameron, S. L., Barker, S. C., \& Whiting, M. F. (2006). Mitochondrial genomics and the new insect order Mantophasmatodea. Molecular phylogenetics and evolution, 38(1), 274-279.

Camousseight, A. (1995). Revisión taxonómica del género Agathemera (Phasmatodea: Pseudophasmatidae) en Chile. Revista Chilena de Entomología, 22, 35-53.

Cancello, E. M., Silva, R. R., Vasconcellos, A., Reis, Y. T., \& Oliveira, L. M. (2014). Latitudinal variation in termite species richness and abundance along the Brazilian Atlantic Forest hotspot. Biotropica, 46(4), 441-450. https://doi.org/10.1111/btp.12120

Carlucci, M. B., Marcilio-Silva, V., \& Torezan, J. M. (2021). The southern Atlantic Forest: use, degradation, and perspectives for conservation. In The Atlantic Forest (pp. 91-111). Springer, Cham.

Chen, S., Yin, X., Lin, X., Shih, C., Zhang, R., Gao, T., \& Ren, D. (2018). Stick insect in Burmese amber reveals an early evolution of lateral lamellae in the Mesozoic. Proceedings of the Royal society B: Biological Sciences, 285(1877), 20180425. https://doi.org/10.1098/rspb.2018.0425

Chen, S., Deng, S. W., Shih, C., Zhang, W. W., Zhang, P., Ren, D., Zhu, Y. \& Gao, T. P. (2019). The earliest Timematids in Burmese amber reveal diverse tarsal pads of stick 
insects in the mid-Cretaceous. Insect Science, 26(5), 945-957. https://doi.org/10.1111/1744-7917.12601

Chiquetto-Machado, P. I., Amorim, F. W., \& Duarte, M. (2018). Long-term stability of the hawkmoth fauna (Lepidoptera, Sphingidae) in a protected area of Brazilian Atlantic Rain Forest. Journal of Insect Conservation, 22(2), 277-286.

Chiquetto-Machado, P. I., \& Cancello, E. M. (2021). Cladistic analysis of Paraphasma (Phasmatodea: Pseudophasmatidae) highlights the importance of the phallic organ for phasmid systematics. Zoological Journal of the Linnean Society. https://doi.org/10.1093/zoolinnean/zlab004

Compton, S., \& Ware, A. B. (1991). Ants disperse the elaiosome-bearing eggs of an African stick insect. Psyche, 98(2-3), 207-213. https://doi.org/10.1155/1991/18258

Conle, O. V., Hennemann, F. H. \& Gutiérres, Y. 2011. The Stick Insects (Phasmatodea) of Colombia: A Catalog and Bibliography with the Description of Four New Genera and 74 New Species. BOD, Norderstedt, 1st Edition. 412 pp.

Conle, O. V., Hennemann, F. H., Bellanger, Y., Lelong, P., Jourdan, T., \& Valero, P. (2020). Studies on neotropical Phasmatodea XX: a new genus and 16 new species from French Guiana. Zootaxa, 4814(1), 1-136. https://doi.org/10.11646/zootaxa.4814.1.1

Crispino, E. B., Chiquetto-Machado, P. I., Engelking, P. W., \& Cancello, E. M. (2020). Contributions to the knowledge of Canuleius Stål (Phasmatodea: Heteronemiidae): taxonomy, morphology and notes on the biology of two species. Zootaxa, 4743(4), zootaxa-4743. https://doi.org/10.11646/zootaxa.4743.4.3

Cumming, R. T., Le Tirant, S., Teemsma, S. N., Hennemann, F. H., Willemse, L., \& Büscher, T. H. (2020). Lost lovers linked at long last: elusive female Nanophyllium mystery solved after a century of being placed in a different genus (Phasmatodea, Phylliidae) ZooKeys, 969, 43. https://doi.org/10.3897/zookeys.969.56214

Didham, R. K., Basset, Y., Collins, C. M., Leather, S. R., Littlewood, N. A., Menz, M. H., Müller, J., Packer, L., Saunders, M. E., Schönrogge, K., Steward, A. J. A., Yanoviak, S. P. \& Hassall, C. (2020). Interpreting insect declines: seven challenges and a way forward. Insect Conservation and Diversity, 13(2), 103-114. https://doi.org/10.1111/icad.12408

Domínguez, M. C., San-Blas, G. E. R. M. A. N., Agrain, F., Roig-Junent, S. A., Scollo, A. M., \& Debandi, G. O. (2009). Cladistic, biogeographic and environmental niche analysis of the species of Agathemera Stål (Phasmatida, Agathemeridae). Zootaxa, $2308(1), 43-57$. 
Engel, M. S., Wang, B., \& Alqarni, A. S. (2016). A thorny,'anareolate'stick-insect (Phasmatidae sl) in Upper Cretaceous amber from Myanmar, with remarks on diversification times among Phasmatodea. Cretaceous Research, 63, 45-53. https://doi.org/10.1016/j.cretres.2016.02.015

Eisner, T., Morgan, R. C., Attygalle, A. B., Smedley, S. R., Herath, K. B., \& Meinwald, J. E. R. R. O. L. D. (1997). Defensive production of quinoline by a phasmid insect (Oreophoetes peruana). The Journal of experimental biology, 200(19), 2493-2500. https://doi.org/10.1242/jeb.200.19.2493

Feitosa, R. M., de Castro Morini, M. S., Martins, A. C., de Andrade Ribeiro, T. M., Noll, F. B., dos Santos, E. F., Cancello, E. M. \& Constantini, J. P. (2021). Social insects of the Atlantic Forest. Em: The Atlantic Forest (pp. 151-183). Springer, Cham.

Ferraz, B. \& Crispino, E. B. (Submetido) How Ghosts Disappear: A case study of the first record of reversible color change in a Heteronemiidae (Phasmatodea) stick insect. Physiological Entomology.

Forni, G., Plazzi, F., Cussigh, A., Conle, O., Hennemann, F., Luchetti, A., \& Mantovani, B. (2021). Phylomitogenomics provides new perspectives on the Euphasmatodea radiation (Insecta: Phasmatodea). Molecular Phylogenetics and Evolution, 155, 106983. https://doi.org/10.1016/j.ympev.2020.106983

Galetti, M., Gonçalves, F., Villar, N., Zipparro, V. B., Paz, C., Mendes, C., Lautenschlager, L., Souza, Y., Akkawi, P., Pedrosa, F., Bulascoschi, L., Bello, C., Sevá, A. P., Sales, L., Genes, L., Abra, F. \& Bovendorp, R. S. (2021). Causes and consequences of large-scale defaunation in the Atlantic forest. Em: The Atlantic Forest (pp. 297-324). Springer, Cham.

Ghirotto, V. M. (2021). Unmasking a master of camouflage: The rich morphology, taxonomy, and biology of the Brazilian stick insect Canuleius similis (Phasmatodea: Heteronemiidae), with general considerations on phasmid genitalia. Zoologischer Anzeiger, 292, 30-57. https://doi.org/10.1016/i.jcz.2021.02.009

Ghirotto, V. M., Crispino, E. B., Chiquetto-Machado, P. I., Neves, P. A. B. A., Engelking, P. W. \& Ribeiro, G. C. (Submetido) The oldest Euphasmatodea (Insecta, Phasmatodea): modern morphology in an Early Cretaceous stick insect fossil from the Crato Formation of Brazil. Paleontology.

Ghirotto, V. M., Crispino, E. B., Engelking, P. W., Neves, P. A. B. A., Góis-Silva, J. de, \& Chiquetto-Machado, (Submetido) Alien or native? On Phantasca stick insects (Phasmatodea: Diapheromerinae) with reassessment of Brazilian species misplaced in Australian genera and description of two new species. Austral Entomology. 
Goldberg, J., Bresseel, J., Constant, J., Kneubühler, B., Leubner, F., Michalik, P., \& Bradler, S. (2015). Extreme convergence in egg-laying strategy across insect orders. Scientific reports, 5(1), 1-7. https://doi.org/10.1038/srep07825

Gottardo, M., \& Vallotto, D. (2014). External macro-and micromorphology of the male of the stick insect Hermarchus leytensis (Insecta: Phasmatodea) with phylogenetic considerations. Comptes Rendus Biologies, 337(4), 258-268. https://doi.org/10.1016/j.crvi.2014.02.005

Gullan, P. J. \& Cranston, P. S. 2005. The Insects. An Outline of Entomology, Blackwell Publishing, Oxford.

Günther, K. (1953). Über die taxonomische Gliederung und die geographische Verbreitung der Insektenordnung der Phasmatodea. Beiträge zur Entomologie= Contributions to Entomology, 3(5), 541-563.

Gustafson, J. F. (1966). Biological observations on Timema californica (Phasmoidea: Phasmidae). Annals of the entomological Society of America, 59(1), 59-61. https://doi.org/10.1093/aesa/59.1.59

Gutiérrez-Valencia, J., Gutiérrez, Y., \& G. Dias, L. (2017). Species delimitation in the crypsis-defended and polymorphic stick insects of the genus Libethra (Phasmatodea, Diapheromeridae). Zoologica Scripta, 46(6), 693-705. https://doi.org/10.1111/zsc. 12242

Grimaldi, D., Engel, M. S., Engel, M. S., \& Engel, M. S. (2005). Evolution of the Insects. Cambridge University Press.

Heleodoro, R. A. (2016). Filogenia e taxonomia de Dinelytron Gray, 1835, com implicações em Prisopodini (Phasmatodea: Prisopodidae).

Heleodoro, R. A., Andreazze, R., \& Rafael, J. A. (2017). Redescription of Malacomorpha cancellata (Phasmatodea: Pseudophasmatidae): a geographically misplaced $\begin{array}{llll}\text { Neotropical } & \text { species. } & \text { Zoologia } & \text { (Curitiba), }\end{array}$ https://doi.org/10.3897/zoologia.34.e20476

Helm, C., Treulieb, S., Werler, K., Bradler, S., \& Klass, K. D. (2011). The male genitalia of Oxyartes lamellatus-phasmatodeans do have complex phallic organs (Insecta: Phasmatodea). Zoologischer Anzeiger-A Journal of Comparative Zoology, 250(3), 223-245. https://doi.org/10.1016/j.jcz.2011.04.005

Hennemann, F. H., \& Conle, O. V. (2006). Papuacocelus papuanus n. gen., n. sp.-a new Eurycanthinae from Papua New Guinea, with notes on the genus Dryococelus Gurney, 1947 and description of the egg (Phasmatodea: Phasmatidae: Eurycanthinae). Zootaxa, 1375(1), 31-49. 
Hennemann, F. H., \& Conle, O. V. (2010). Studies on neotropical Phasmatodea X: redescriptions of Aplopocranidium Zompro, 2004 and Jeremia Redtenbacher, 1908, with a survey of the tribe Cladomorphini Brunner v. Wattenwyl, 1893 and keys to the genera (insecta: phasmatodea:" anareolatae": Cladomorphinae). Journal of Orthoptera Research, 101-113.

Hennemann, F. H., \& Conle, O. V. (2021). Studies on Neotropical Phasmatodea XIX: The enigmatic genus Laciphorus Redtenbacher, 1908 from Coastal Peru (Phasmatodea: Diapheromeridae: Diapheromerinae). Studies on Neotropical Fauna and Environment, 56(2), 83-92. https://doi.org/10.1080/01650521.2020.1736743

Hennemann, F. H., Conle, O. V., \& Perez-Gelabert, D. E. (2016). Studies on Neotropical Phasmatodea XVI: Revision of Haplopodini Günther, 1953 (rev. stat.), with notes on the subfamily Cladomorphinae Bradley \& Galil, 1977 and the descriptions of a new tribe, four new genera and nine new species (Phasmatodea:"Anareolatae": Phasmatidae: $\quad$ Cladomorphinae). Zootaxa, 4128(1), 1-211. http://doi.org/10.11646/zootaxa.4128.1.1

Hennemann, F., Conle, O., Bellanger, Y., Lelong, P., \& Jourdan, T. (2018). Studies on neotropical Phasmatodea XVII: Revision of Phantasca Redtenbacher, 1906, with the descriptions of six new species (Phasmatodea: Diapheromeridae: Diapheromerinae). European Journal of Taxonomy, (435). https://doi.org/10.5852/ejt.2018.435

Hennig, W. 1966. Phylogenetic systematics. University of Illinois Press.

Huber, B. A. (2010). Mating positions and the evolution of asymmetric insect genitalia. Genetica, 138(1), 19-25. https://doi.org/10.1007/s10709-008-9339-6

Hughes, L., \& Westoby, M. (1992). Capitula on stick insect eggs and elaiosomes on seeds: convergent adaptations for burial by ants. Functional Ecology, 6(6), 642-648. https://doi.org/10.2307/2389958

Huiñocana, J. C. S., Albertoni, E. F., Picolotto, R. C., Milesi, S. V., \& Hepp, L. U. (2020). Nestedness of insect assemblages in agriculture-impacted Atlantic forest streams. In Annales de Limnologie-International Journal of Limnology (Vol. 56, p. 3). EDP Sciences.

Kirby, W. F. (1904). LI.-Notes on Phasmidæ in the collection of the British Museum (Natural History), South Kensington, with description of new genera and species.-No. II. Journal of Natural History, 13(78), 429-449. https://doi.org/10.1080/00222930408562475

Kjer, K. M. (2004). Aligned 18S and insect phylogeny. Systematic biology, 53(3), 506-514. https://doi.org/10.1080/10635150490445922 
Kjer, K. M., Carle, F. L., Litman, J., \& Ware, J. (2006). A molecular phylogeny of Insecta. Arthropod Systematics \& Phylogeny, 64(1), 35-44.

Kumagai, A. F., \& Fonseca, N. G. D. (2009). Uma nova espécie de Cladomorphus Gray, 1835 (Phasmatidae, Cladomorphinae) de Minas Gerais, Brasil. Revista Brasileira de Entomologia, 53, 41-44.

Latreille; Peletier de Saint Fargeau; Audinet-Serville \& Guérin-Méneville. (1825) Encyclopédie Méthodique, ou par ordre de matières par un société de gens de lettres, de savans et d'artistes. Histoire Naturelle. 1-344

Latreille; Peletier de Saint Fargeau; Audinet-Serville \& Guérin-Méneville. (1828). Encyclopédie Méthodique, ou par ordre de matières par un société de gens de lettres, de savans et d'artistes. Histoire Naturelle. 10:345-832

Letsch, H., \& Simon, S. (2013). Insect phylogenomics: new insights on the relationships of lower neopteran orders (Polyneoptera). Systematic Entomology, 38(4), 783-793. https://doi.org/10.1111/syen.12028

Lima, A. R., Kumagai, A. F., \& Neto, F. C. C. (2013). Morphological and biological observations on the stick insect Tithonophasma tithonus (Gray, 1835) (Phasmida: Pseudophasmatidae: Pseudophasmatinae). Zootaxa, 3700(4), 588-592. http://dx.doi.org/10.11646/zootaxa.3700.4.7

Lins-e-Silva, A. C. B., Ferreira, P. S. M., \& Rodal, M. J. N. (2021). The North-Eastern Atlantic Forest: Biogeographical, Historical, and Current Aspects in the Sugarcane Zone. Em: The Atlantic Forest (pp. 45-61). Springer, Cham.

Middleton, B. A., \& Grace, J. B. (2004). Biodiversity and ecosystem functioning: synthesis and perspectives. Restoration Ecology, 12(4), 611-612. https://doi.org/10.1111/i.1061-2971.2004.120401.x

Madeira-Ott, T., Thyssen, P. J., \& Costa, J. (2020). Phasmatodea (Arthropoda, Insecta) in Brazil: status, new record, and proposal for using molecular tools to assist in species identification. Neotropical Entomology, 49(6), 916-922. https://doi.org/10.1007/s13744-020-00798-3

Marques, M. C., Trindade, W., Bohn, A., \& Grelle, C. E. (2021). The Atlantic Forest: An introduction to the megadiverse forest of South America. Em: The Atlantic Forest ,(pp. 3-23). Springer, Cham. https://doi.org/10.1007/978-3-030-55322-7 1

Mazzini, M., Carcupino, M., \& Fausto, A. M. (1993). Egg chorion architecture in stick insects (Phasmatodea). International Journal of Insect Morphology and Embryology, 22(2-4), 391-415. https://doi.org/10.1016/0020-7322(93)90021-R 
Misof, B., Liu. S., Meusemann. K., Peters, R. S., Donath, A., Mayer, C., Frandsen, P. B. Ware, J., Flouri, T., Beutel, R. G., Niehuis, O., Petersen, M., Izquierdo-Carrasco, F., Wappler, T., Rust, J., Aberer, J. A., Aspöck, A., Aspöck, H., Bartel, D., Blanke, A., Berger, S., Böhm, A., Buckley, T. R., Calcott, B., Chen, J., Friedrich, F., Fukui, M., Fujita, M., Greve, C., Grobe, P., Gu, S., Huang, Y., Jermiin, L. S., Kawahara, A. Y., Krogmann, L., Kubiak, M., Lanfear R., Letsch, H., Li, Y., Li, Z., Li, J., Lu, H., Machida, R., Mashimo, Y., Kapli, P., McKenna, D. D., Meng G., Nakagaki, Y., Navarrete-Heredia, J. L., Ott, M., Ou, Y., Pass, G., Podsiadlowski, L., Pohl, H., von Reumont,B. M., Schütte, K., Sekiya, K., Shimizu, S., Slipinski, A., Stamatakis, A., Song, W., Su, X., Szucsich, N. U., Tan, M., Tan, X., Tang, M., Tang, J., Timelthaler, G., Tomizuka, S., Trautwein, M., Tong, X., Uchifune, T., Walzl, M. G., Wiegmann, B. M., Wilbrandt, J., Wipfler, B., Wong, T. K. F., Wu, Q., Wu, G., Xie, Y., Yang, X., Yang, Q., Yeates, D. K., Yoshizawa, K., Zhang, Q., Zhang, R., Zhang, W., Zhang, Y., Zhao, J., Zhou, C., Zhou, L., Ziesmann, T., Zou, S., Li, Y., Xu, X., Zhang, Y., Yang, H., Wang, J., Wang, J., Kjer, K. M. \& Zhou X. (2014). Phylogenomics resolves the timing and pattern of insect evolution. Science, 346(6210), 763-767. https://doi.org/10.1126/science.1257570

Myers, N., Mittermeier, R. A., Mittermeier, C. G., Da Fonseca, G. A., \& Kent, J. (2000). Biodiversity hotspots for conservation priorities. Nature, 403(6772), 853-858.

Pinto, L. P., Bedê, L., Paese, A., Fonseca, M., Paglia, A., \& Lamas, I. (2006). Mata Atlântica Brasileira: os desafios para conservação da biodiversidade de um hotspot mundial. Biologia da conservação: essências. São Carlos: RiMa, 91-118.

Plazzi, F., Ricci, A., \& Passamonti, M. (2011). The mitochondrial genome of Bacillus stick insects (Phasmatodea) and the phylogeny of orthopteroid insects. Molecular Phylogenetics and Evolution, 58(2), 304-316. https://doi.org/10.1016/j.ympev.2010.12.005

Redtenbacher, J. (1906). I. Tribus Bacillini, II. Tribus Obrimini, III. Tribus Pygirhynchini, IV. Tribus Ascepasmini, V. Tribus Anisomorphini, VI. Tribus Phasmini, VII. Tribus Heteropterygini, VIII. Tribus Phyllini. Die Insektenfamilie der Phasmiden. Wilhelm Engelmann, Leipzig, 1-180

Redtenbacher, J. (1908). XII. Tribus Phibalosomini, XIII. Tribus Acrophyllini, XIV. Tribus Necrosciini. Die Insektenfamilie der Phasmiden. Wilhelm Engelmann, Leipzig, 339-572.

Rezende, C. L., Scarano, F. R., Assad, E. D., Joly, C. A., Metzger, J. P., Strassburg, B. B. N., Tabarelli, M., Fonseca, G. A. \& Mittermeier, R. A. (2018). From hotspot to hopespot: 
An opportunity for the Brazilian Atlantic Forest. Perspectives in ecology and conservation, 16(4), 208-214.

Roberts, H. R. (1941). A comparative study of the subfamilies of the Acrididae (Orthoptera) primarily on the basis of their phallic structures. Proceedings of the Academy of Natural Sciences of Philadelphia, 93, 201-246.

Robertson, J. A., Bradler, S., \& Whiting, M. F. (2018). Evolution of oviposition techniques in stick and leaf insects (Phasmatodea). Frontiers in Ecology and Evolution, 6, 216. https://doi.org/10.3389/fevo.2018.00216

Rosenberg, D. M., Danks, H. V., \& Lehmkuhl, D. M. (1986). Importance of insects in environmental impact assessment. Environmental management, 10(6), 773-783. https://doi.org/10.1007/bf01867730

Roskov Y., Orrell T., Nicolson D., Bailly N., Kirk P.M., Bourgoin T., DeWalt R.E., Decock W., De Wever A., Nieukerken E. van, Zarucchi J. \& Penev L., eds. (2018). Species 2000 \& ITIS Catalogue of Life, 2018 annual checklist. [www.catalogueoflife.org/col.] Último acesso em 09/09/2021.

Saussure, H., D. (1859). Orthoptera Nova Americana. (Diagnosis Praeliminares I). Revue et Magazine de Zoologie. (2)11:59-63.

Saussure, H., D. (1861). Orthoptera Nova Americana (Diagnosis Praeliminares) II. Revue et Magazine de Zoologie. (2)13:126-212.

Saussure, H., D. (1862[1861]). Etudes sur quelques orthoptères du musée de Genève nouveaux ou imparfaitement connus. Annales de la Société Entomologique de France. (4)1:469-494, pls. 11-12.

Saussure, H., D. (1868a). Orthoptorum species novae Aliquot. Revue et Magazine de Zoologie. (2)20:354-357.

Saussure, H., D. (1868b). Phasmidarum novarum species nonullae. Revue et Magazine de Zoologie. (2)20:63-70.

Saussure, H., D. (1869). Mélanges orthoptèrologiques II Blattides et Phasmides. Mémoires de la Société de physique et de l'histoire naturelle de Genève. 20:227-326.

Saussure, H., D. (1872[1870-1872]). Etudes sur les insectes orthoptères. Familles des phasmides et des mantides. In Edwards, D.S. Etudes sur les insectes orthoptères. Mission scientifique au Mexique et dans l'Amérique Centrale. Recherches zoologiques. 6(1):125-201, pl. 3-4

Sellick, J. T. C. (1988). The capitula of phasmid eggs: an update with a review of the current state of phasmid ootaxonomy. Zoological Journal of the Linnean Society, 93(3), 273-282. https://doi.org/10.1111/j.1096-3642.1988.tb01364.x 
Sellick, J. T. C. (1994) Phasmida (Stick Insect) eggs from the Eocene of Oregon. Paleontology, 37(4), 913-921.

Sellick, J. T. C. (1997a). Descriptive terminology of the phasmid egg capsule, with an extended key to the phasmid genera based on egg structure. Systematic Entomology, 22(2), 97-122. https://doi.org/10.1046/j.1365-3113.1997.d01-30.x

Sellick, J. T. C. (1997b). The range of egg capsule morphology within the Phasmatodea and its relevance to the taxonomy of the order. Italian Journal of Zoology, 64(1), 97-104. https://doi.org/10.1080/11250009709356178

Sellick, J. T. C. (1998). The micropylar plate of the eggs of Phasmida, with a survey of the range of plate form within the order. Systematic Entomology, 23(3), 203-228. https://doi.org/10.1046/j.1365-3113.1998.00056.x

Shelomi, M., Jasper, W. C., Atallah, J., Kimsey, L. S. \& Johnson, B. R. (2014). Differential expression of endogenous plant cell wall degrading enzyme genes in the stick insect (Phasmatodea) midgut. BMC genomics, 15(1), 1-18. https://doi.org/10.1186/1471-2164-15-917

Simon, S., Letsch, H., Bank, S., Buckley, T. R., Donath, A., Liu, S., Machida, R., Meusemann, K., Misof, B., Podsiadlowski, L., Zhou, X., Wipfler, B. \& Bradler, S. (2019). Old World and New World Phasmatodea: phylogenomics resolve the evolutionary history of stick and leaf insects. Frontiers in Ecology and Evolution, 7, 345. https://doi.org/10.3389/fevo.2019.00345

Sivinski, J. (1978). Intrasexual aggression in the stick insects, Diapheromera veliei and D. covilleae, and sexual dimorphism in the Phasmatodea. Psyche, 85(4), 395-405.

Stal, C. (1858). Orthoptera och Hemiptera fran Sodra-Africa. Öfversigt af Svenska Vetenskaps-Akad: s förhandlingar, 15, 307-320.

Stål, C. (1875a). Observations Orthoptérologiques. I. Sur une systématisation nouvelle des Phasmides. Bihang till Kongliga Svenska Vetenskaps-akadiems Handlingar, 3(14), $1-43$.

Stal, C. (1875b). Recherches sur le Système des Phasmides. PA Norstedt \& Söner.

Stål, C. (1875c). Öfversigt af Kongliga Vetenskaps-Akademiens Förhandlingar. Recensio Orthopterorum. Revue critique des Orthopteres, Decrits Par, Linne De Geer et Thunberg. PA Norstedt \& Söner, Stockholm, Sweden, 32, 105.

Stal, C. (1876). Bidrag till södra Afrikas Orthopter-fauna.

Stål, C. (1877a). Espèces nouvelles de Phasmides. Annales de la Société Entomologique de Belgique, Comptes Rendues, 20, 62-68. 
Stål. (1877b). Orthoptera nova ex Insulis Philippinis descripsit. Öfversigt af Kongliga Vetenskaps-Akademiens Förhandlingar. 34 (10):33-58

Stork, N. E., McBroom, J., Gely, C., \& Hamilton, A. J. (2015). New approaches narrow global species estimates for beetles, insects, and terrestrial arthropods. Proceedings of the National Academy of Sciences, 112(24), 7519-7523. https://doi.org/10.1073/pnas.1502408112

Stork, N. E. (2018). How many species of insects and other terrestrial arthropods are there on Earth?. Annual review of entomology, 63, 31-45. https://doi.org/10.1146/annurev-ento-020117-043348

Suetsugu, K., Funaki, S., Takahashi, A., Ito, K., \& Yokoyama, T. (2018). Potential role of bird predation in the dispersal of otherwise flightless stick insects. Ecology, 99(6), 1504-1506.

Terry, M. D., \& Whiting, M. F. (2005). Mantophasmatodea and phylogeny of the lower neopterous insects. $\quad$ Cladistics, 21(3), 250-257. https://doi.org/10.1111/j.1096-0031.2005.00062.x

Tihelka, E., Cai, C., Giacomelli, M., Pisani, D., \& Donoghue, P. C. (2020). Integrated phylogenomic and fossil evidence of stick and leaf insects (Phasmatodea) reveal a Permian-Triassic co-origination with insectivores. Royal Society open science, 7(11), 201689. https://doi.org/10.1098/rsos.201689

Tilgner, E. H., Kiselyova, T. G., \& McHugh, J. V. (1999). A morphological study of Timema cristinae Vickery with implications for the phylogenetics of Phasmida. Deutsche Entomologische Zeitschrift, $\quad 46(2), \quad$ 149-162. https://doi.org/10.1002/mmnd.19990460203

Toledo Piza, S. de. (1936a). Um novo Phasmida do Brasil (Orth.). Revista de Entomologia, 6, 98-100.

Toledo Piza, S. de. (1936b). Os Phasmidas do Museu Paulista. I. Phasmidae, Bacillinae. Revista de Entomologia, 6, 280-292.

Toledo Piza, S. de. (1937). Os Phasmidas do Museu Paulista. II. Phasmidae, Phasminae. Revista de Entomologia, 7, 1-8.

Toledo Piza, S. de. (1938a). Os Phasmidas do Museu Paulista. III. Phasmidae, Cladoxerinae. Revista de Entomologia, 8, 40-44.

Toledo Piza, S. de. (1938b). Novos Phasmidas do Brasil e da Argentina (Orth.). Revista de Entomologia, 9, 1-11. 
Toledo Piza, S. de. (1939). Dois novos Phasmidas do Brasil (Orth.). Revista de Entomologia, $10,444-446$.

Toledo Piza, S. de. (1943). Um Proscopiida e um Phasmida novos do Brasil (Orth.). Revista de Entomologia, 14, 287-291.

Toledo Piza, S. de. (1944). Cinco novas espécies de Phásmidas do Brasil. Anais da Escola Superior de Agricultura "Luiz de Queiroz" , 1, 43-58.

Toledo Piza, S. de. (1946). Um novo Phásmida Pachymorphinae do Brasil, emendas a chave para separação dos machos do gênero Acanthoderus e redistribuição por subfamílias das espécies descritas pelo autor. Anais da Escola Superior de Agricultura "Luiz de Queiroz",3, 149-156.

Toledo Piza, S. de. (1977). Três novas espécies de Pseudophasma (Phasmatodea - Phyllidae). Anais da Escola Superior de Agricultura “Luiz de Queiroz”, 34, 489-491.

Toledo Piza, S. de. 1985a. A segunda espécie do gên. Oestrophora (Phasmatodea-Phyllidae). Revista de Agricultura, 60, 1-2.

Toledo Piza, S. de. (1985). Um novo Stratocles do Brasil (Phasmatodea-Phyllidae). Revista de Agricultura, Vol. 60, pp: 101-102.

Tomita, S., Yukuhiro, K., \& Kômoto, N. (2011). The mitochondrial genome of a stick insect Extatosoma tiaratum (Phasmatodea) and the phylogeny of polyneopteran insects. Journal of Insect Biotechnology and Sericology, 80(3), 3_079-3_088. https://doi.org/10.11416/jibs.80.3 079

Trautwein, M. D., Wiegmann, B. M., Beutel, R., Kjer, K. M., \& Yeates, D. K. (2012). Advances in insect phylogeny at the dawn of the postgenomic era. Annual Review of Entomology, 57, 449-468. https://doi.org/10.1146/annurev-ento-120710-100538

Umbers, K. D., Fabricant, S. A., Gawryszewski, F. M., Seago, A. E., \& Herberstein, M. E. (2014). Reversible colour change in Arthropoda. Biological Reviews, 89(4), 820-848. https://doi.org/10.1111/brv.12079

Wagner, D. L., Grames, E. M., Forister, M. L., Berenbaum, M. R., \& Stopak, D. (2021). Insect decline in the Anthropocene: Death by a thousand cuts. Proceedings of the National Academy of Sciences, 118(2). https://doi.org/10.1073/pnas.2023989118

Wedmann, S., Bradler, S., \& Rust, J. (2007). The first fossil leaf insect: 47 million years of specialized cryptic morphology and behavior. Proceedings of the National Academy of Sciences, 104(2), 565-569. https://doi.org/10.1073/pnas.0606937104

Westwood, J. O. (1859). Catalogue of Orthopterous Insects in the Collection of the British Museum: Part I. Phasmidæ. Order of the Trustees. British Museum, London. 
Wheeler, W. C., Whiting, M., Wheeler, Q. D., \& Carpenter, J. M. (2001). The phylogeny of the extant hexapod orders. Cladistics, 17(2), 113-169. https://doi.org/10.1006/clad.2000.0147

Whitfield, J. B., \& Kjer, K. M. (2008). Ancient rapid radiations of insects: challenges for phylogenetic analysis. Annual Review of Entomology, 53, 449-472. https://doi.org/10.1146/annurev.ento.53.103106.093304

Whiting, M. F. (2002). Mecoptera is paraphyletic: multiple genes and phylogeny of Mecoptera and Siphonaptera. Zoologica scripta, 31(1), 93-104. https://doi.org/10.1046/j.0300-3256.2001.00095.x

Whiting, M. F., Bradler, S., \& Maxwell, T. (2003). Loss and recovery of wings in stick insects. Nature, 421(6920), 264-267.

Willmann, R. (2004). Phylogenetic relationships and evolution of insects. In: Cracraft, J., Donoghue, M.J. (Eds.), Assembling the Tree of Life. Oxford University Press, Oxford, pp: $330-344$.

Yang, H., Shi, C., Engel, M. S., Zhao, Z., Ren, D., \& Gao, T. (2021). Early specializations for mimicry and defense in a Jurassic stick insect. National Science Review, 8(1), nwaa056. https://doi.org/10.1093/nsr/nwaa056

Zompro, O., \& Adis, J. (2001). A new species of Phasmatodea of the genus Echetlus Stål. Revista de Agricultura (Piracicaba), 76(2), 291-297.

Zompro, O. (2001a). "A generic revision of the insect order Phasmatodea: The New World genera of the stick insect subfamily Diaphomeridae: Diapheromerinae = Heteronemiidae: Heteronemiinae sensu Bradley \& Galil 1977”. Revue Suisse de Zoologie. 108(1), 202-203.

Zompro, O. (2001b). Redescription and new synonymies of Heteronemia Gray, 1835 (Insecta: Phasmatodea) transferred to the suborder Areolatae. Studies on Neotropical Fauna and Environment, 36(3), 221-225.

Zompro, O. (2004a). Revision of the genera of the Areolatae, including the status of Timema and Agathemera (Insecta: Phasmatodea). Abhandlungen des Naturwissenschaftlichen Vereins in Hamburg, 37, 1-327.

Zompro, O. (2004b) A Key to the Stick-Insect Genera of the 'Anareolatae' of the New World, with Descriptions of Several New Taxa (Insecta: Phasmatodea). Studies on Neotropical Fauna and Environment, 39(2), 133-144. https://doi.org/10.1080/01650520412331333783 
Zompro O. (2012) Phasmatodea. Em: Insetos do Brasil. Diversidade e Taxonomia (eds. JA Rafael, GAR Melo, vv CJB de Carvalho, SA Casari \& R Constantino), Holos Editora, Ribeirão Preto. pp. 289-295. 


\section{7 - PRANCHAS E TABELAS}

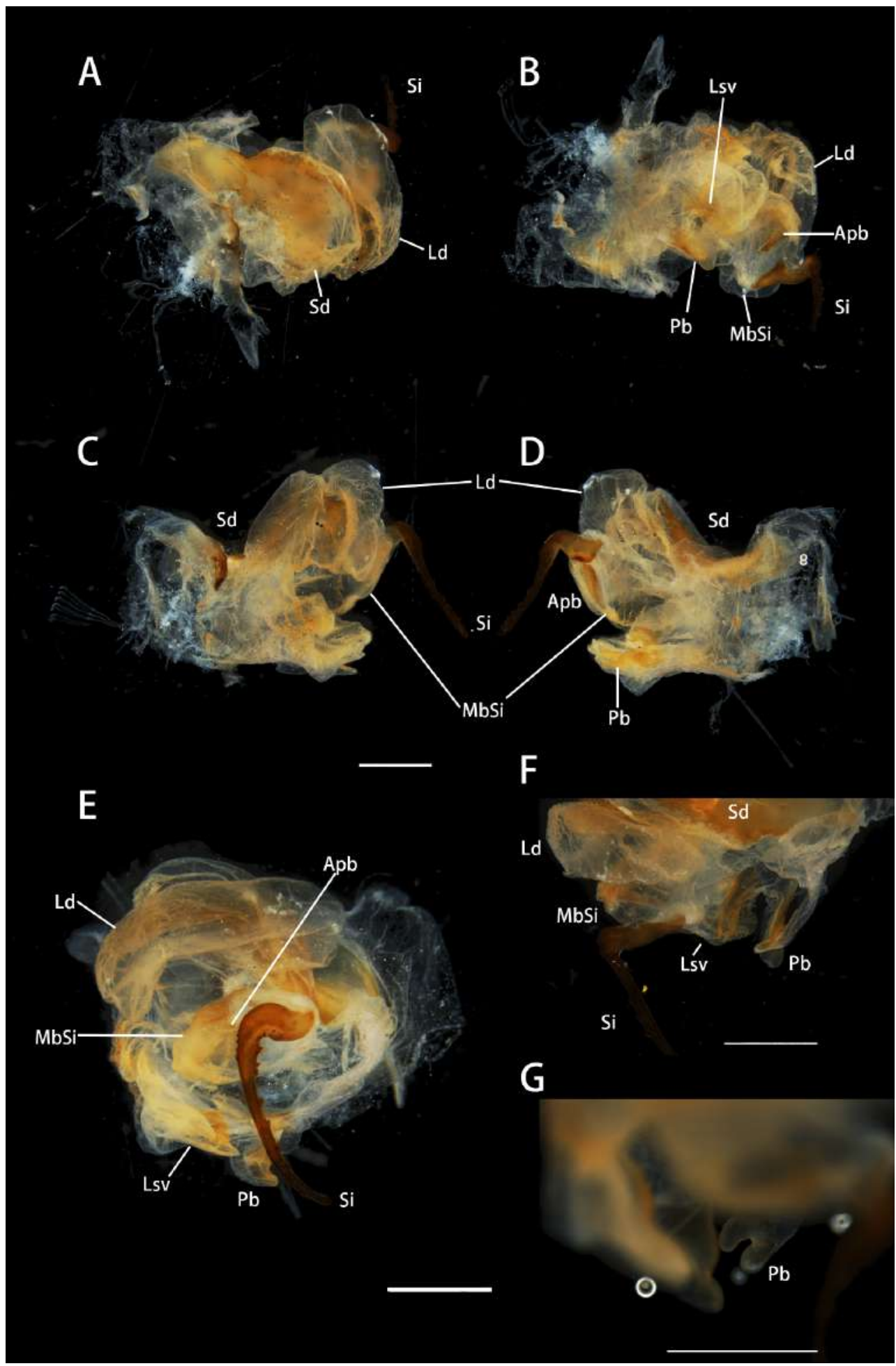

Figura 1: Modelo de genitália masculina de Ceroys. Representada está a genitália de Ceroys (Ceroys) perfoliatus. As estruturas ilustradas na imagem são encontradas em todas as espécies do gênero. A-G: A. Vista dorsal. B. Vista ventral; C. Vista lateral esquerda; D. Vista lateral direita; E. Vista caudal; F. Detalhe em vista superior esquerda; G. Detalhe da Projeção bífida. Abreviações e acrônimos: $\mathbf{S d}$, esclerito dorsal; Si, esclerito interno; $\mathbf{L d}$, lóbulo dorsal; Apb, Apódema basal; Mbsi, Membrana do esclerito interno; Pb, projeção bífida; Lsv, Lóbulo sinuoso ventral. Barra de escala: $1 \mathrm{~mm}$. 


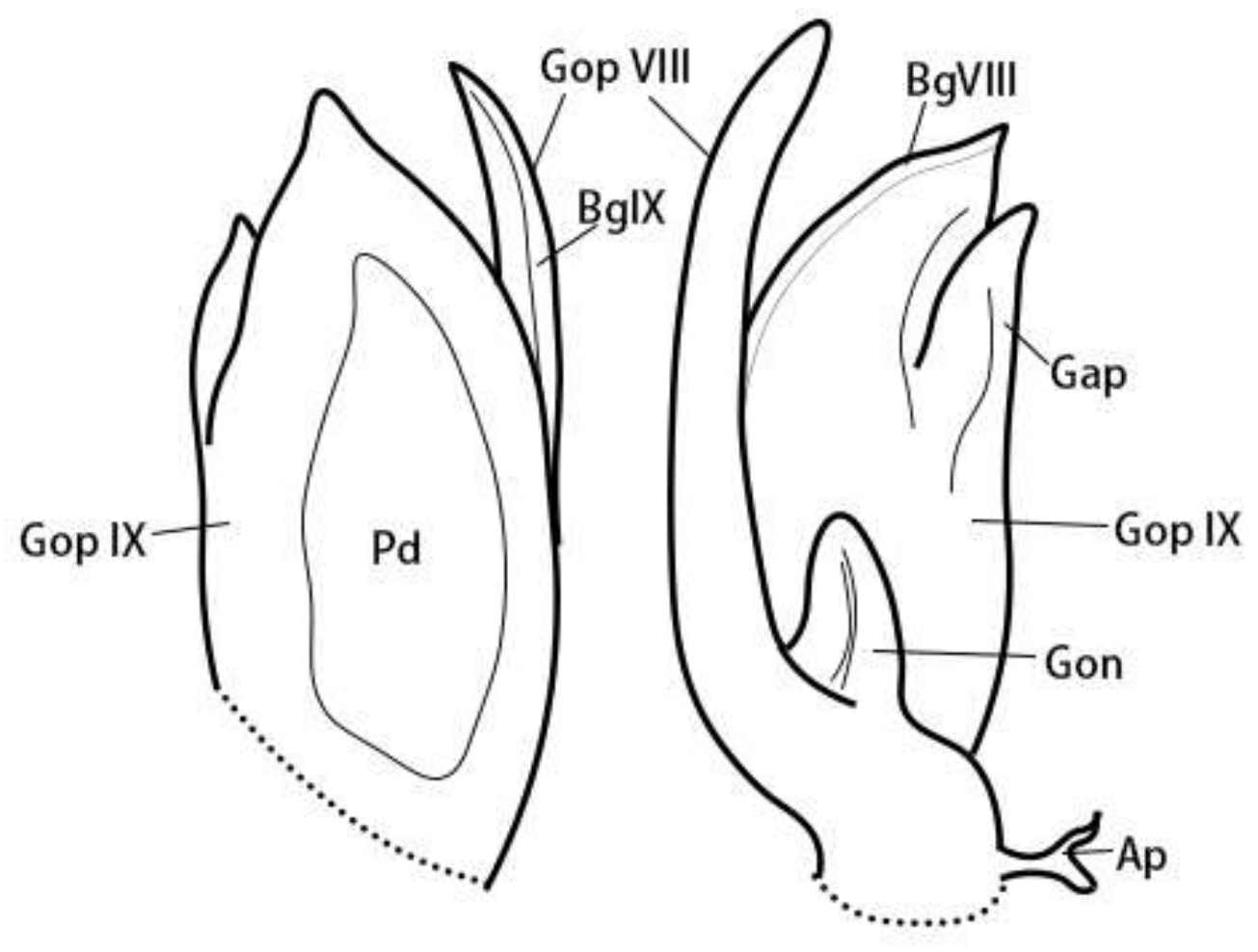

Figura 2: Esquema representativo da estrutura do ovipositor feminino de Ceroys. Vista interna (à esquerda) e externa (à direita) das estruturas constituintes. Acrônimos: Ap: Apódema, BgVIII-IX: Bainha das gonapófises VIII-IX, Gap: gonoplaca, Gop VIII-IX, gonapófises VIII-IX, Gon: Gonângulo, Pd: placa dentada. A linha pontilhada delimita o ponto de fixação dessas estruturas com a musculatura abdominal. Imagens fora de escala. 


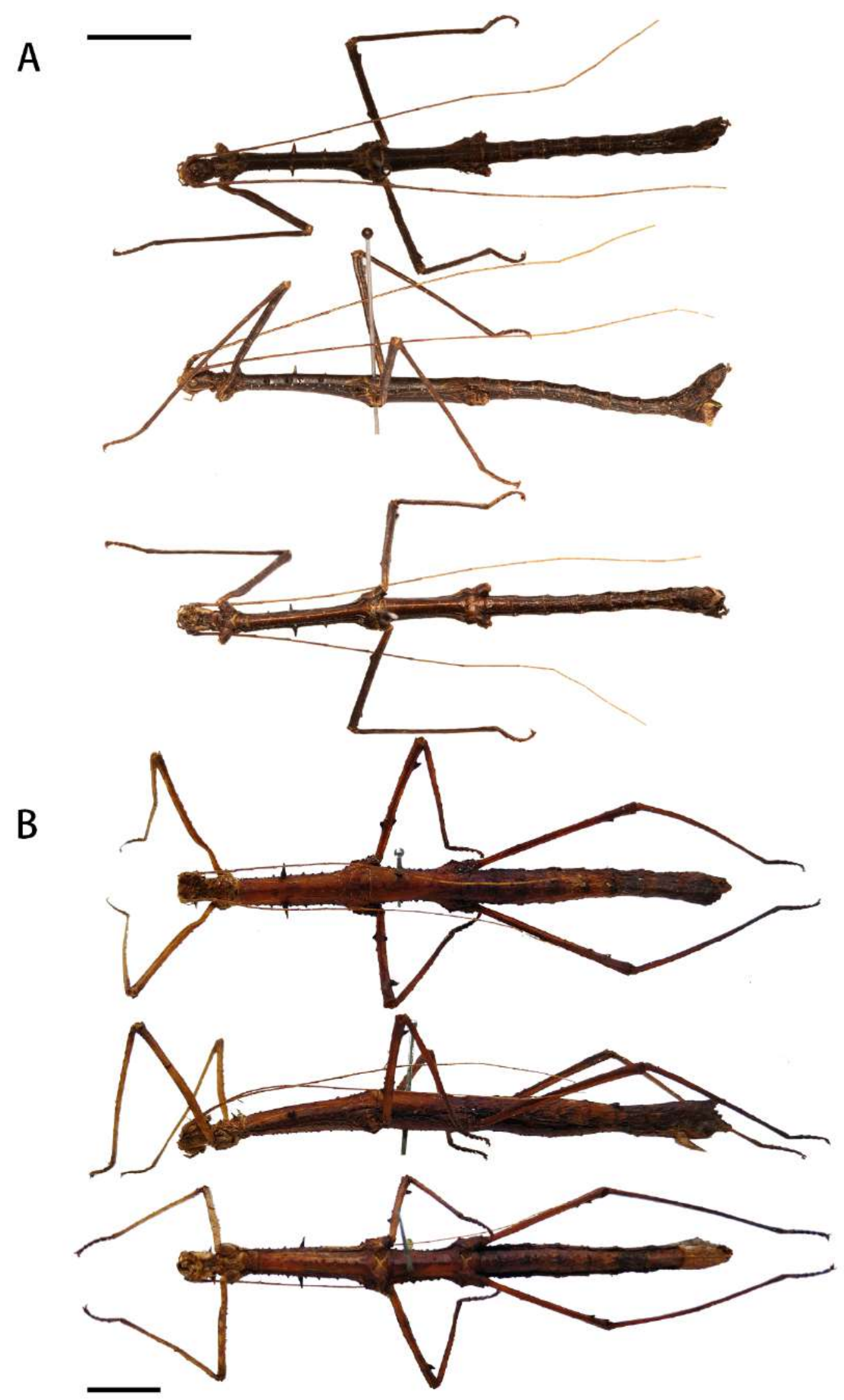

Figura 3: A-B. Holótipos de Ceroys (Ceroys) albogranulatus Piza, 1938 syn. nov. (A) e Ceroys (Ceroys) spinosus Zompro, 2004 syn. nov. (B) A. Macho adulto de Ceroys (Ceroys) perfoliatus em vista dorsal, lateral e ventral. B. Fêmea adulta de Ceroys (Ceroys) perfoliatus em vista dorsal, lateral e ventral. Barra de escala: $10 \mathrm{~mm}$. 

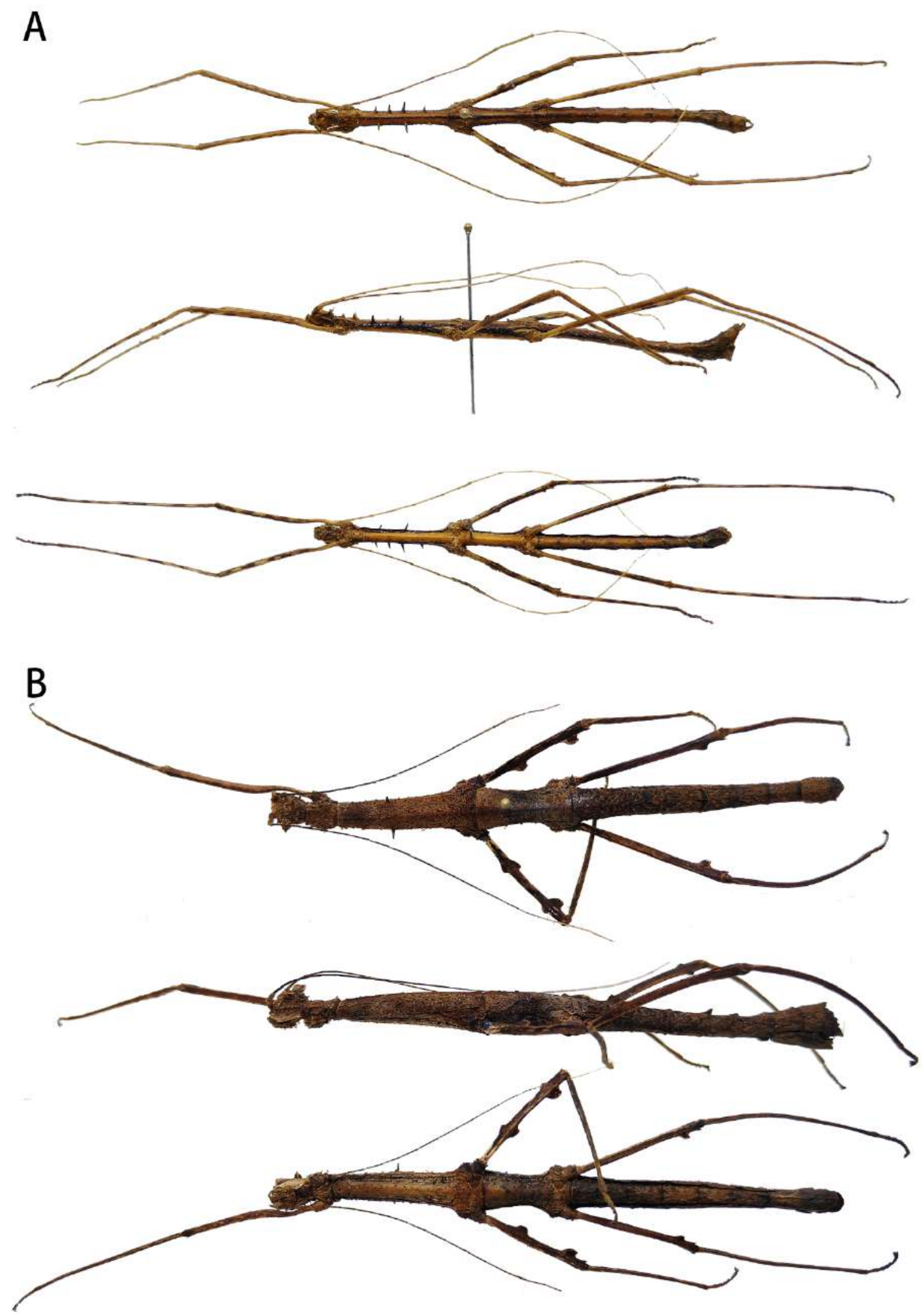

Figura 4: Habitus de Ceroys (Ceroys) perfoliatus. A. Macho adulto em vista dorsal, lateral e ventral B. Fêmea adulta em vista dorsal, lateral e ventral. Barra de escala: $10 \mathrm{~mm}$. 

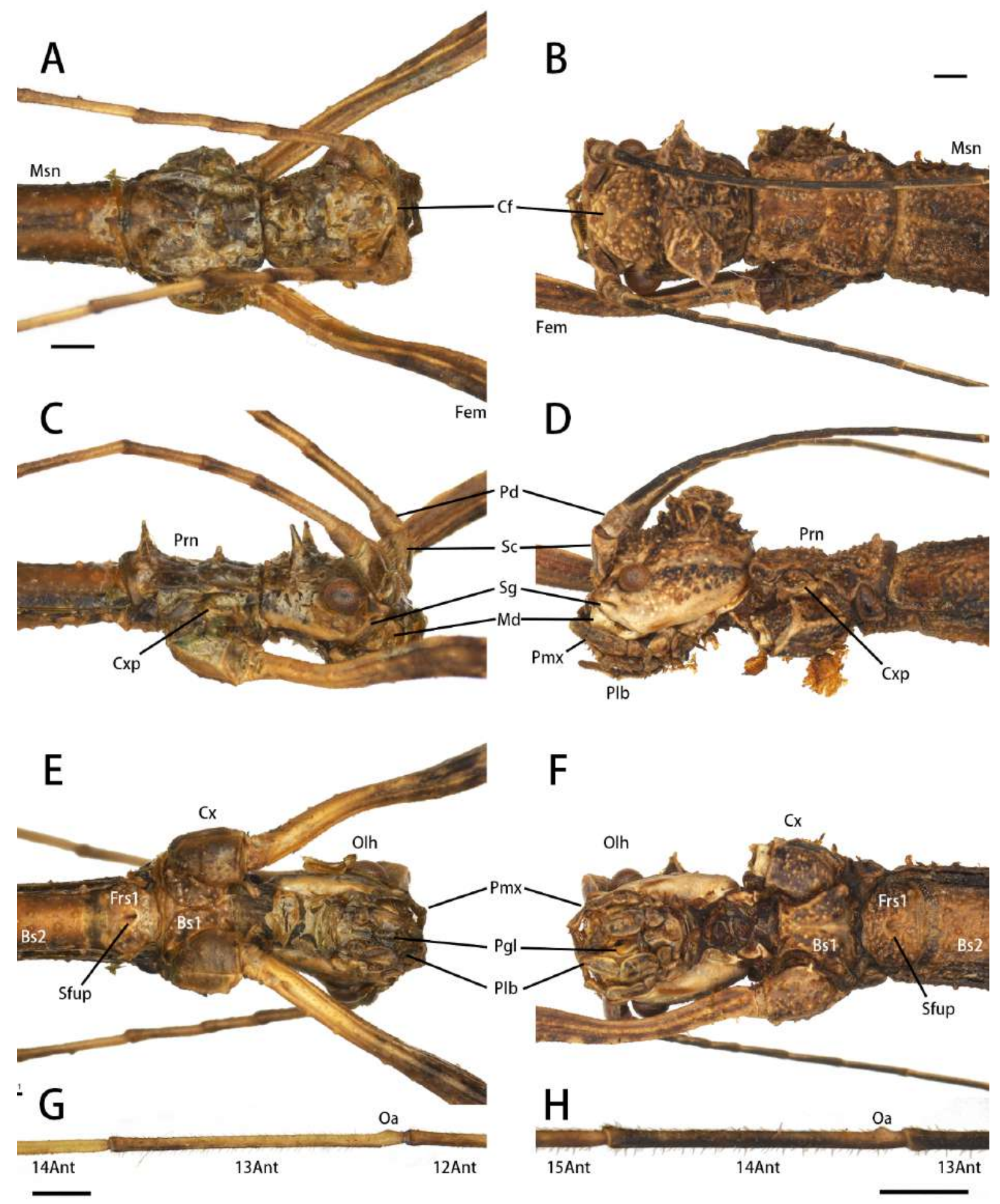

Figura 5: A-F. Detalhe da cabeça de Ceroys (Ceroys) perfoliatus. A, C, E. Macho adulto: A. Vista dorsal; C. Vista lateral; E. Vista ventral. B, D, E. Fêmea adulta: B. Vista dorsal; D. Vista lateral; F. Vista ventral. G, H. Detalhe das antenas mostrando o órgão antenal do macho (G) e fêmea (H). Abreviações e acrônimos: Ant, antenômero; Bs1-Bs2, basisterno pro- e mesotorácico; Cx, coxa; Cxp, coxopleurito; Olh, olho; Cf, Convexidade frontal; Fem, fêmur; Frs1, furcasternito protorácico; Sf, sutura frontal; Md, mandíbula; Msn, mesonoto; Pd, pedicelo; Pgl, paraglossa; PIb, Palpo labial; Pmx, palpo maxilar; Prn, pronoto; Sc, escapo; Sg, subgena; Sfup, sulco furcasternal; Oa, órgão antenal. Barra de escala: $1 \mathrm{~mm}$. 


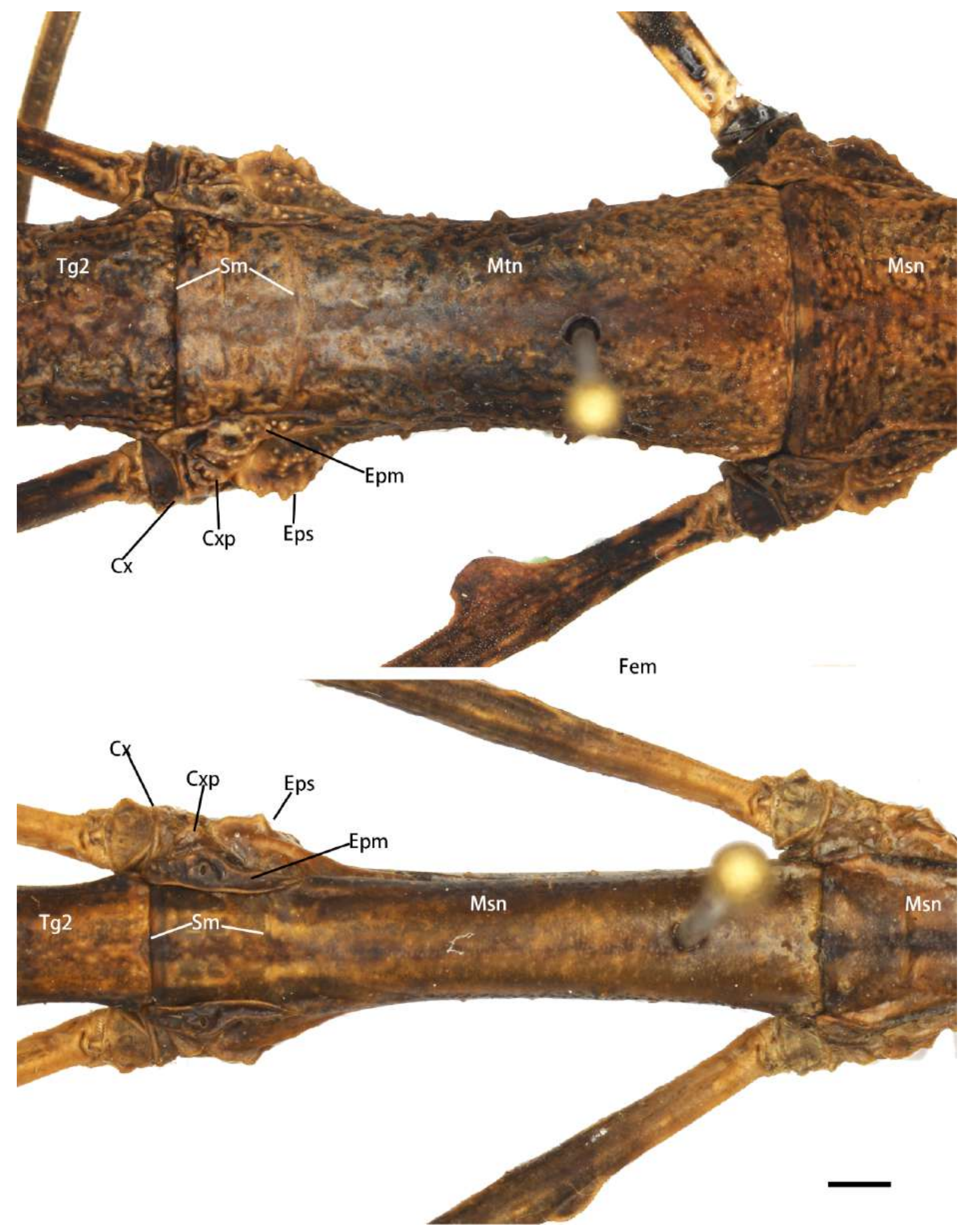

Figura 6: A-B. Morfologia do metatórax de Ceroys (Ceroys) perfoliatus em vista dorsal. A. Fêmea B. Macho. Abreviações e acrônimos: Cx, coxa; Cxp, coxopleurito; Epm, epímeron; Eps, episterno; Sm, segmento mediano; Msn, mesonoto; Mtn, metanoto; Tg, tergito; Fem, fêmur. Barra de escala: $1 \mathrm{~mm}$. 


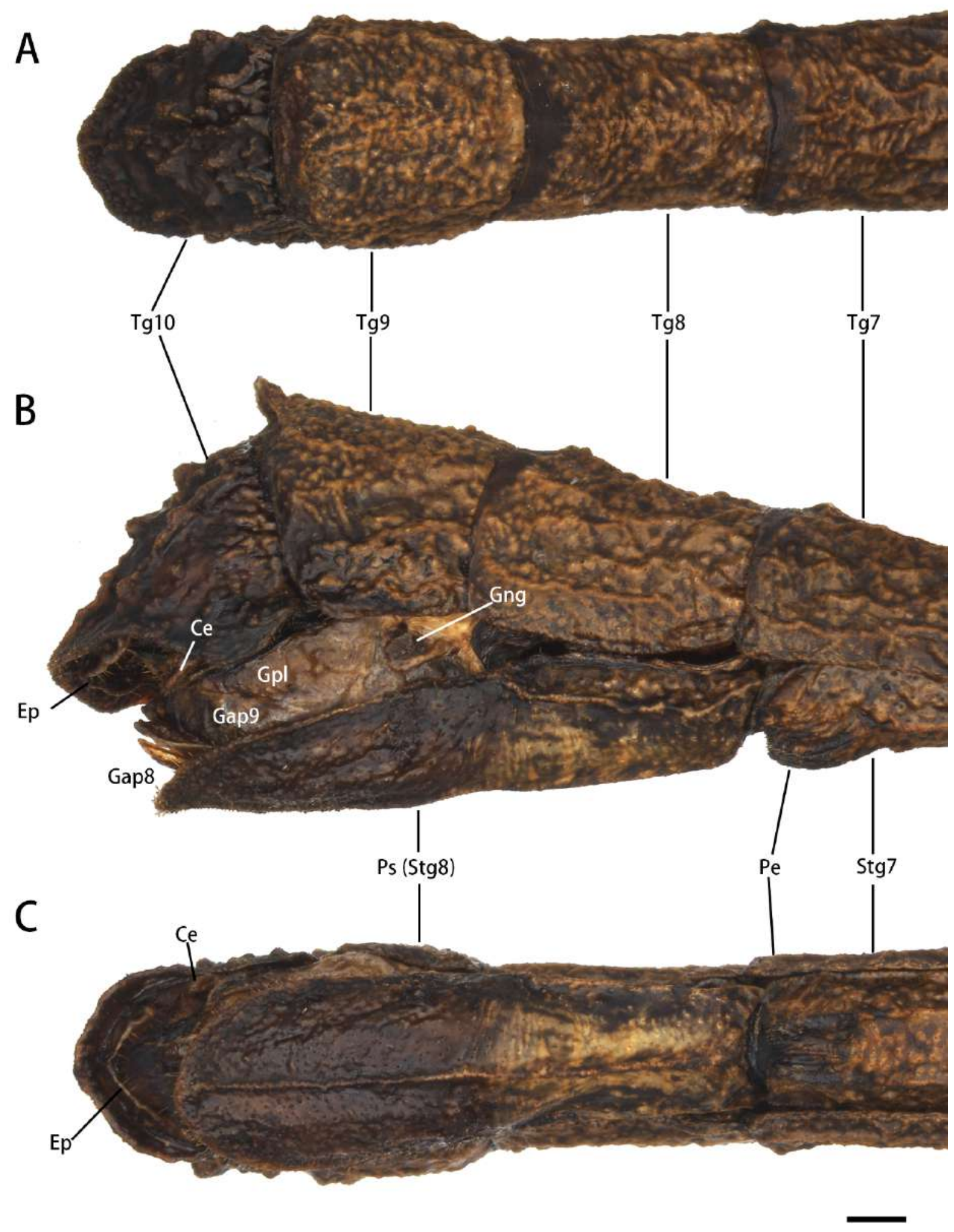

Figura 7:A-C. Morfologia do abdômen e terminália da fêmea de Ceroys (Ceroys) perfoliatus A. Vista dorsal. B. Vista lateral; C. Vista ventral; Abreviações e acrônimos: Ce, cercos; Ep, epiprocto; Gap8-Gap9, gonapófise 8 e 9; Gng, gonângulo; Gpl, gonoplaca; Pe, órgão pré-opercular; Ps, Placa subgenital; St, esternito; Tg, tergito. Barra de escala: $1 \mathrm{~mm}$. 


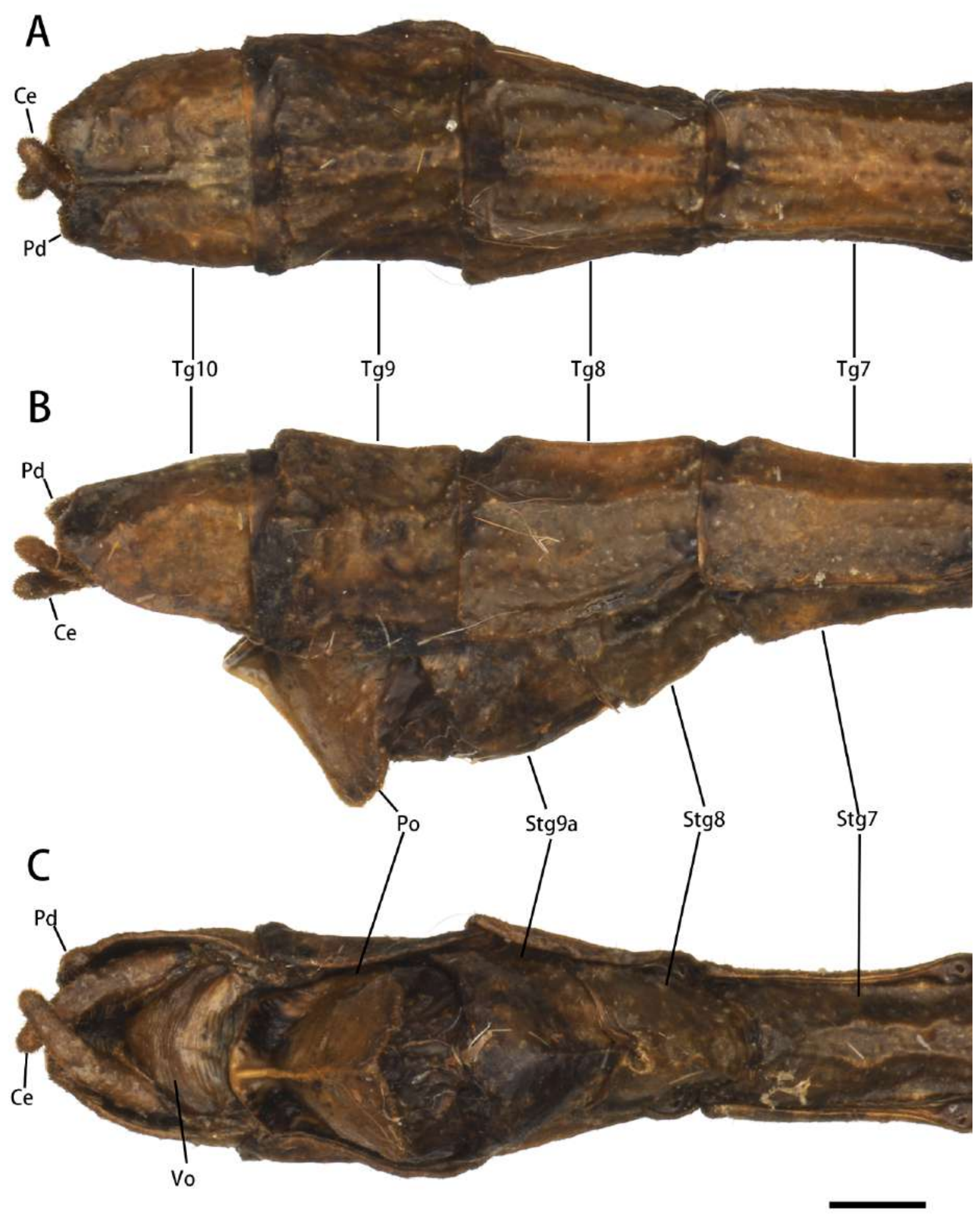

Figura 8:A-C. Morfologia do abdômen e terminália do macho de Ceroys (Ceroys) perfoliatus: A. Vista dorsal. B. Vista posterior; C. Vista ventral. Abreviações e acrônimos: Ce, cercos; Po, poculum; St, esternitos; St9a, porção anterior do esternito 9; Tg, tergito; Pd, placa dentada; Vo, vômer. Barra de escala: $\mathbf{A}-\mathbf{C}=1 \mathrm{~mm}$. 
A

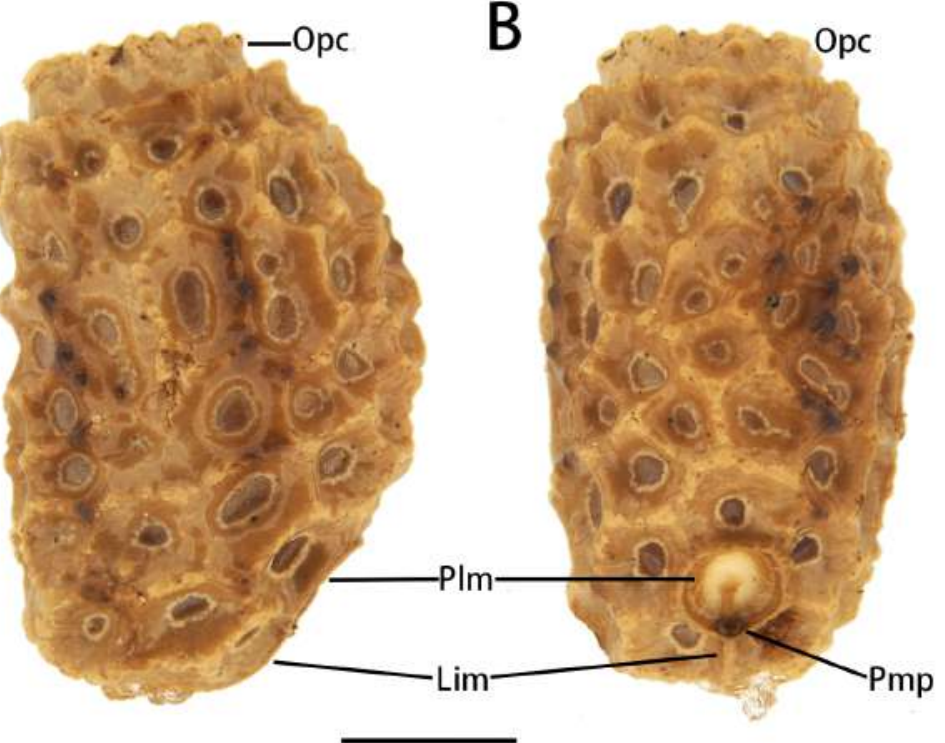

C

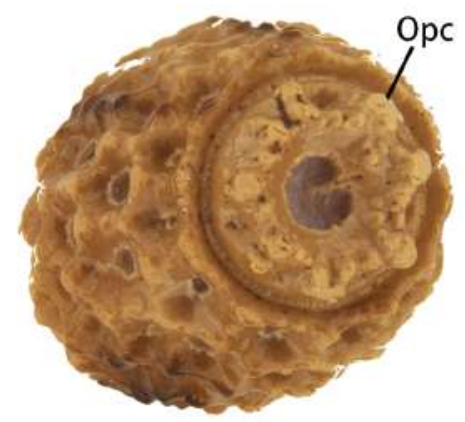

Figura 9: A-C. Ovo de Ceroys (Ceroys) perfoliatus: A. Vista lateral. B. Vista dorsal. C. Vista anterior. Abreviações e acrônimos: Pmp, poro micropilar; PIm, placa micropilar; Lim, linha mediana; Opc, opérculo. Barra de escala: $1 \mathrm{~mm}$.

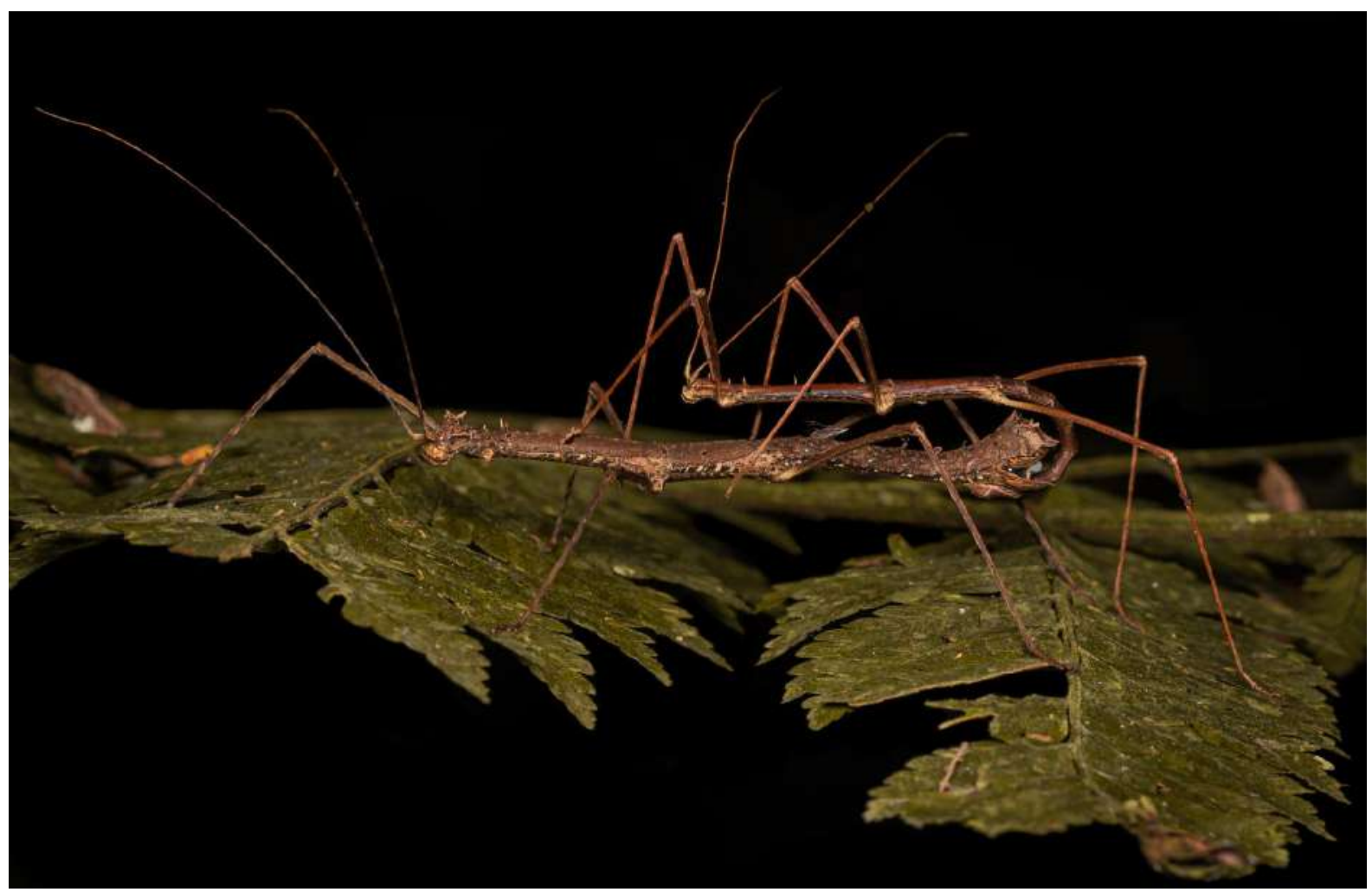

Figura 10: Casal adulto de Ceroys (Ceroys) perfoliatus in situ. É possível ver na foto o momento que o espermatóforo do macho é transferido para a fêmea. Imagem fora de escala. Foto realizada por Phillip Watzke Engelking em Bertioga, São Paulo, Brasil. 


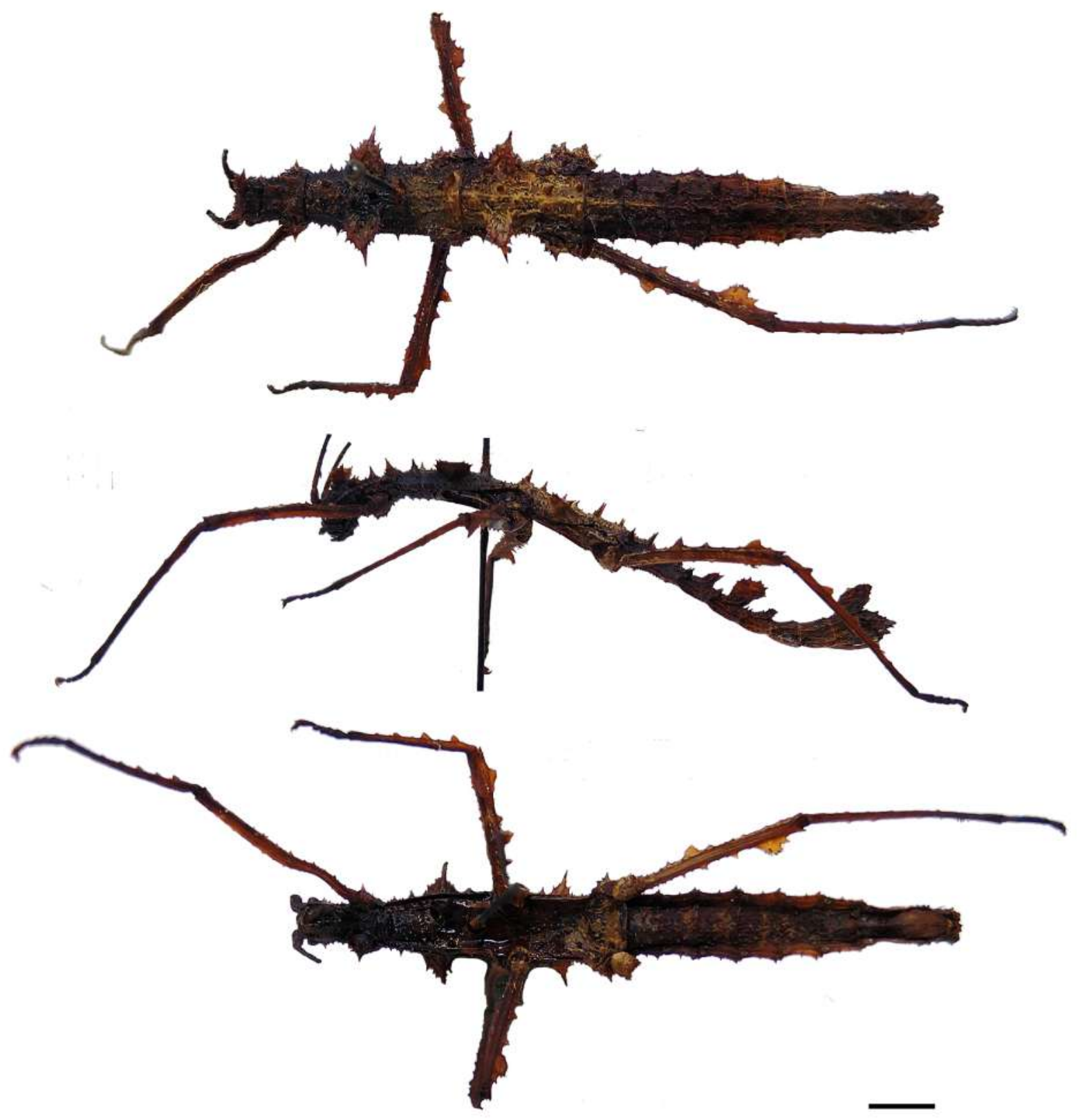

Figura 11: Holótipos de Ceroys (Miroceroys) brunneri Piza, 1936 syn. nov. Fêmea ninfa de Ceroys (Ceroys) cristatus em vista dorsal, lateral e ventral. Barra de escala: $10 \mathrm{~mm}$. 

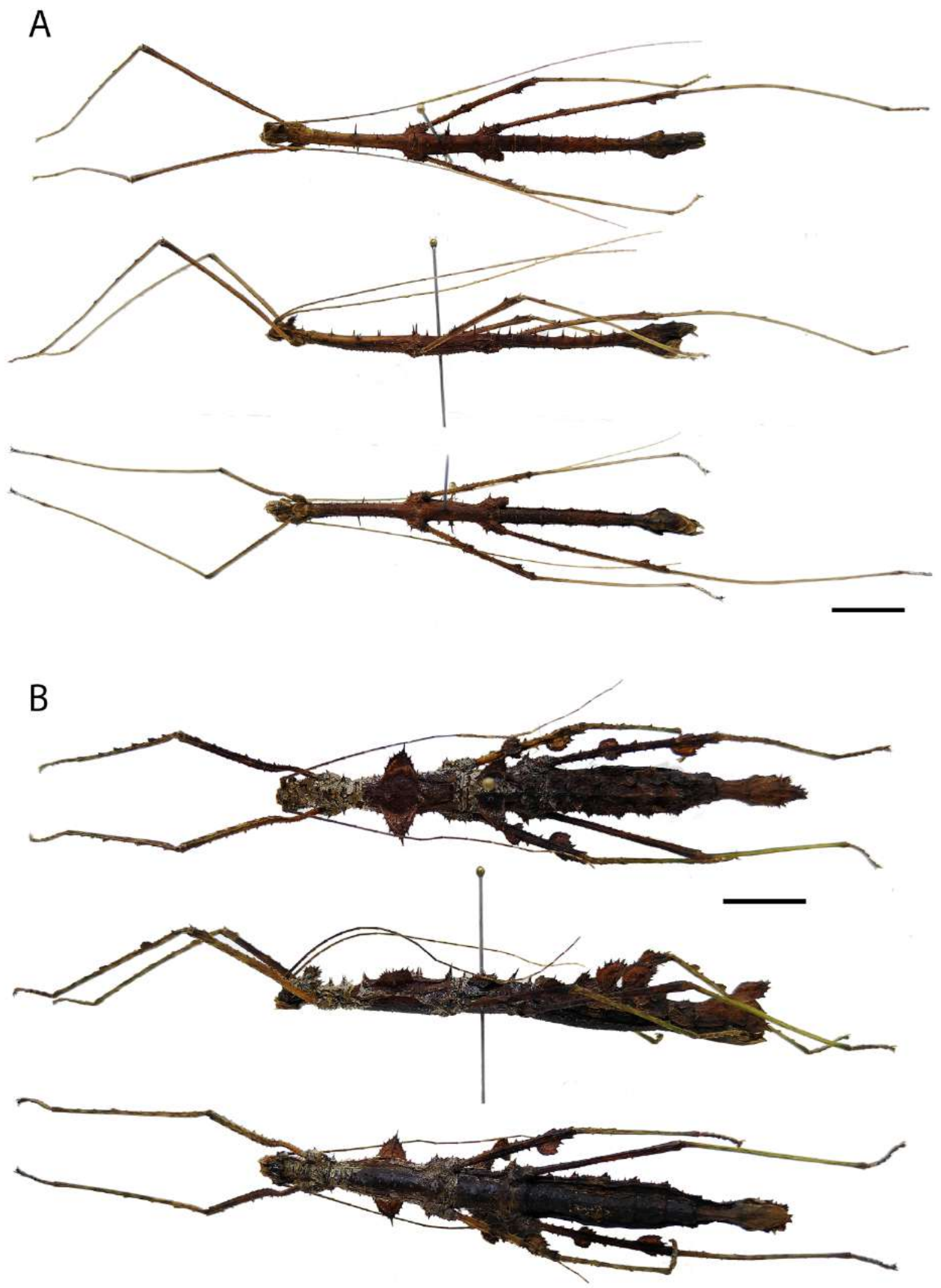

Figura 12: Macho e fêmea adultos de Ceroys (Ceroys) cristatus. A. Macho adulto em vista dorsal, lateral e ventral B. Fêmea adulta em vista dorsal, lateral e ventral. Barra de escala: 10 $\mathrm{mm}$. 


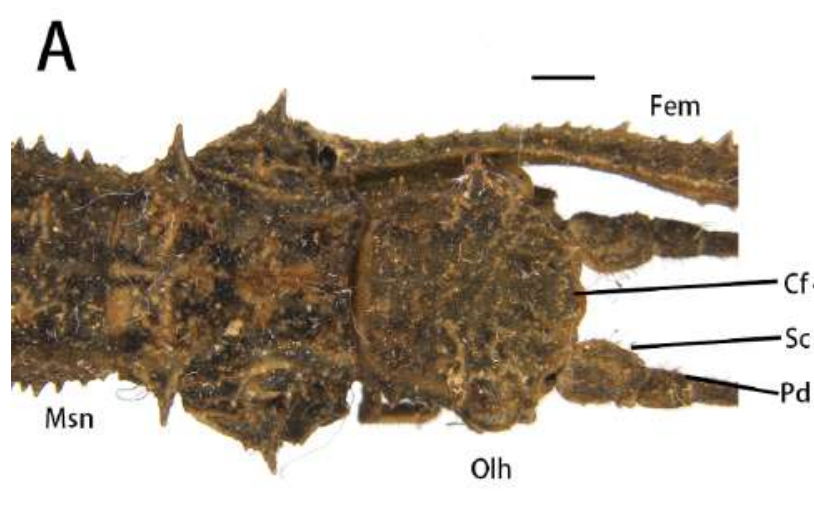

B
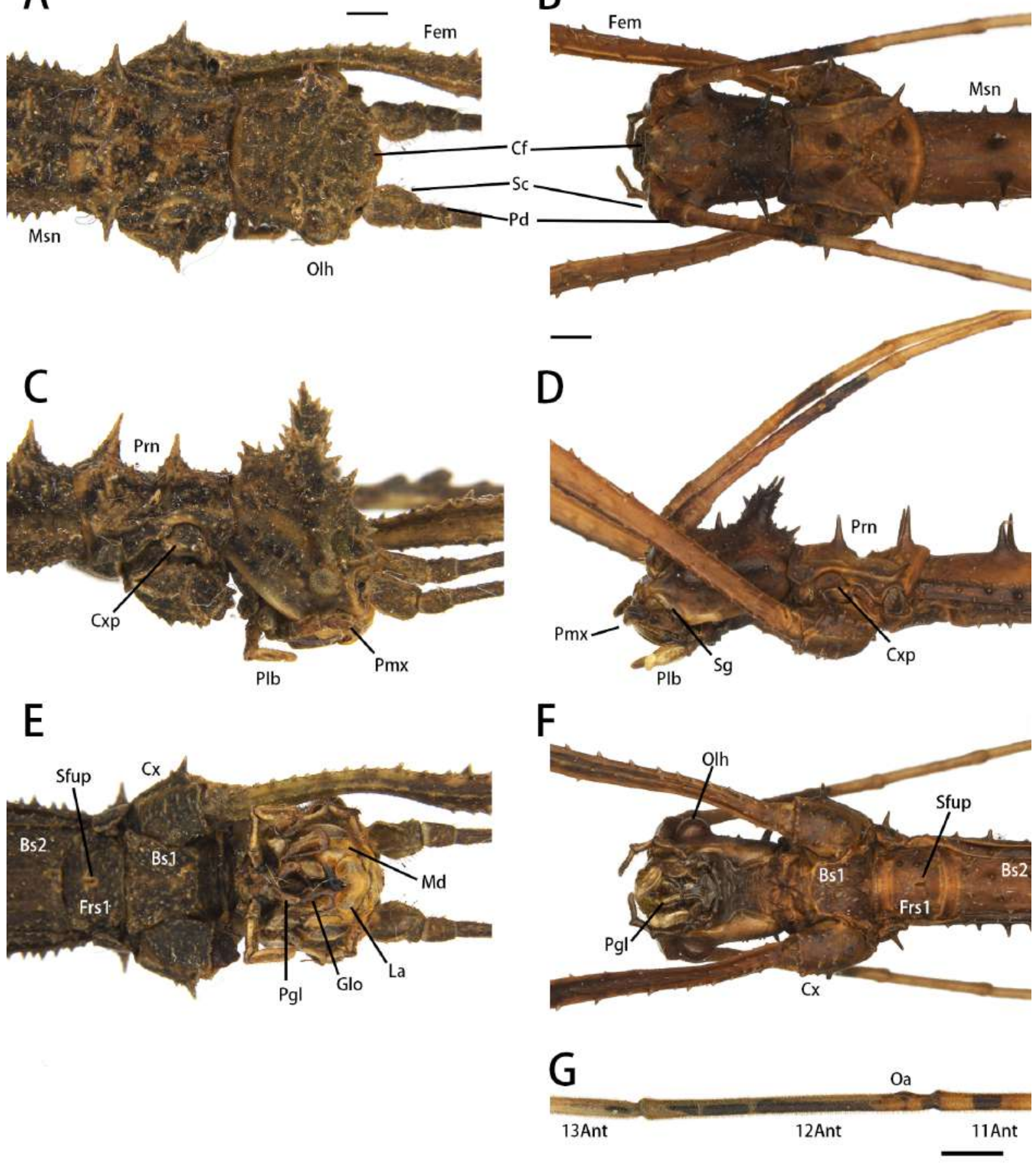

Figura 13: A-F. Detalhe da cabeça de Ceroys (Ceroys) cristatus. A, C, E. Fêmea adulta: A. Vista dorsal; C. Vista lateral; E. Vista ventral. B, D, E. Macho adulto: B. Vista dorsal; D. Vista lateral; F. Vista ventral. G, Detalhe das antenas mostrando o órgão antenal do macho. Abreviações e acrônimos: Ant, antenômero; Bs1-Bs2, basisterno pro- e mesotorácico; Cx, coxa; Cxp, coxopleurito; Olh, olho; Cf, Convexidade frontal; Fem, fêmur; Frs1, furcasternito protorácico; Sf, sutura frontal; Gl, glossa; Md, mandíbula; Msn, mesonoto; Pd, pedicelo; Pgl, paraglossa; Plb, Palpo labial; Pmx, palpo maxilar; Prn, pronoto; Sc, escapo; Sg, subgena; Sfup, sulco furcasternal; La, labro; Oa, órgão antenal. Barra de escala: $1 \mathrm{~mm}$ 

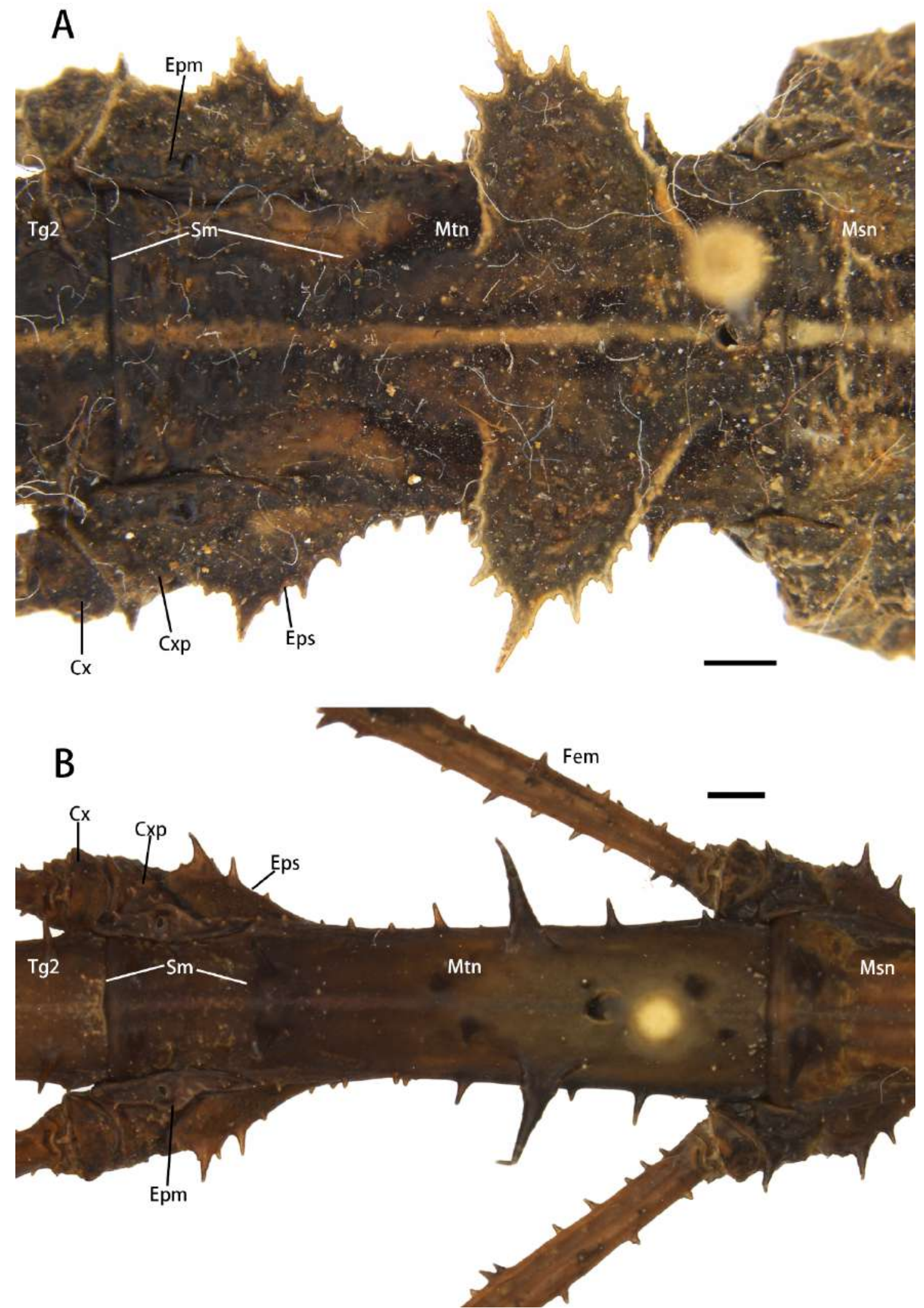

Figura 14: A-B. Morfologia do metatórax de Ceroys (Ceroys) cristatus em vista dorsal. A. Fêmea B. Macho. Abreviações e acrônimos: Cx, coxa; Cxp, coxopleurito; Epm, epímeron; Eps, episterno; Sm, segmento mediano; Msn, mesonoto; Mtn, metanoto; Tg, tergito; Fem, fêmur. Barra de escala: $1 \mathrm{~mm}$. 


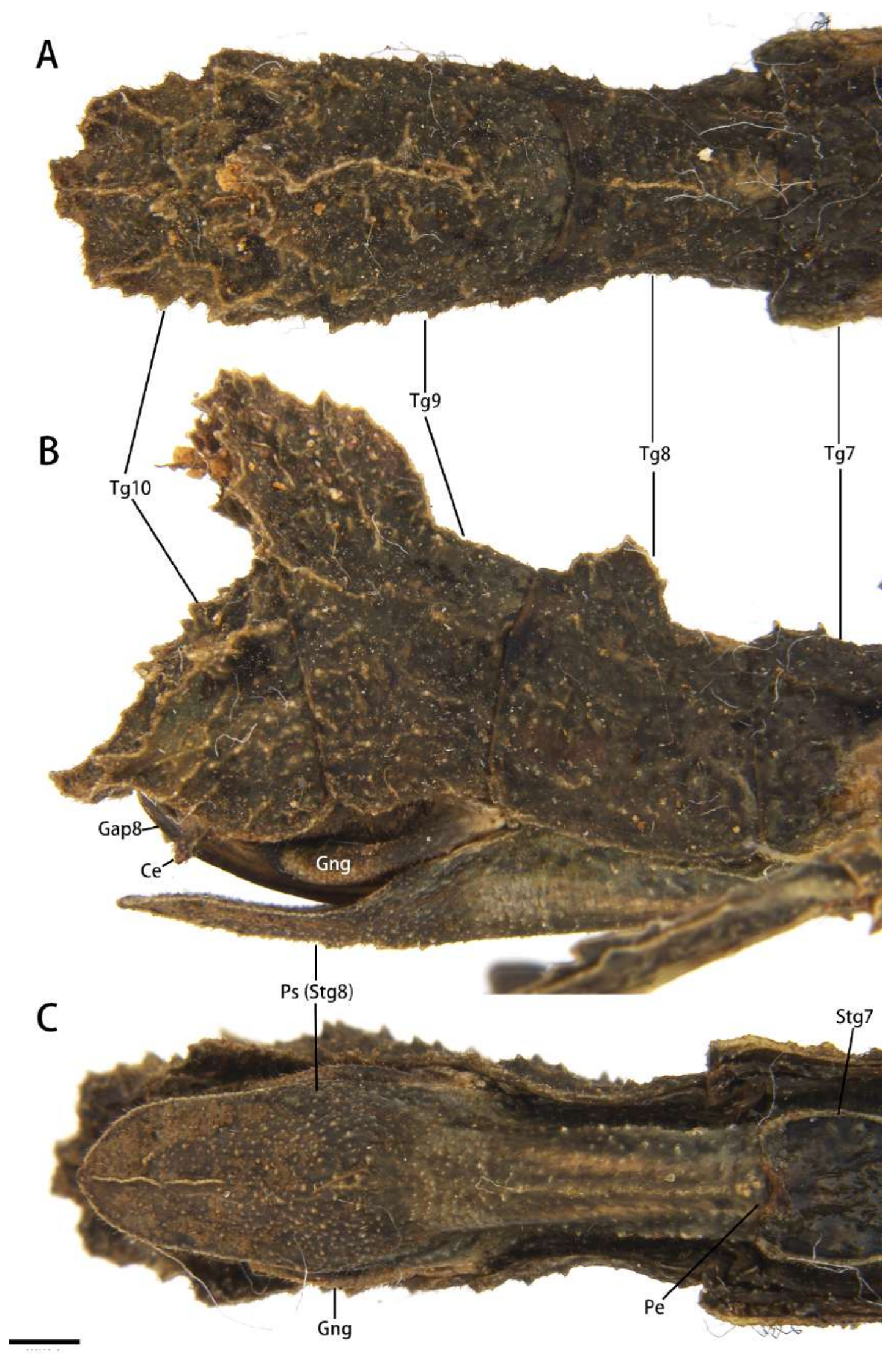

Figura 15:A-C. Morfologia do abdômen e terminália da fêmea de Ceroys (Ceroys) cristatus. A. Vista dorsal. B. Vista lateral; C. Vista ventral; Abreviações e acrônimos: Ce, cercos; Gap8 gonapófise 8; Gng, gonângulo; Gpl, gonoplaca; Pe, órgão pré-opercular; Ps, Placa subgenital; St, esternito; Tg, tergito. Barra de escala: $1 \mathrm{~mm}$. 


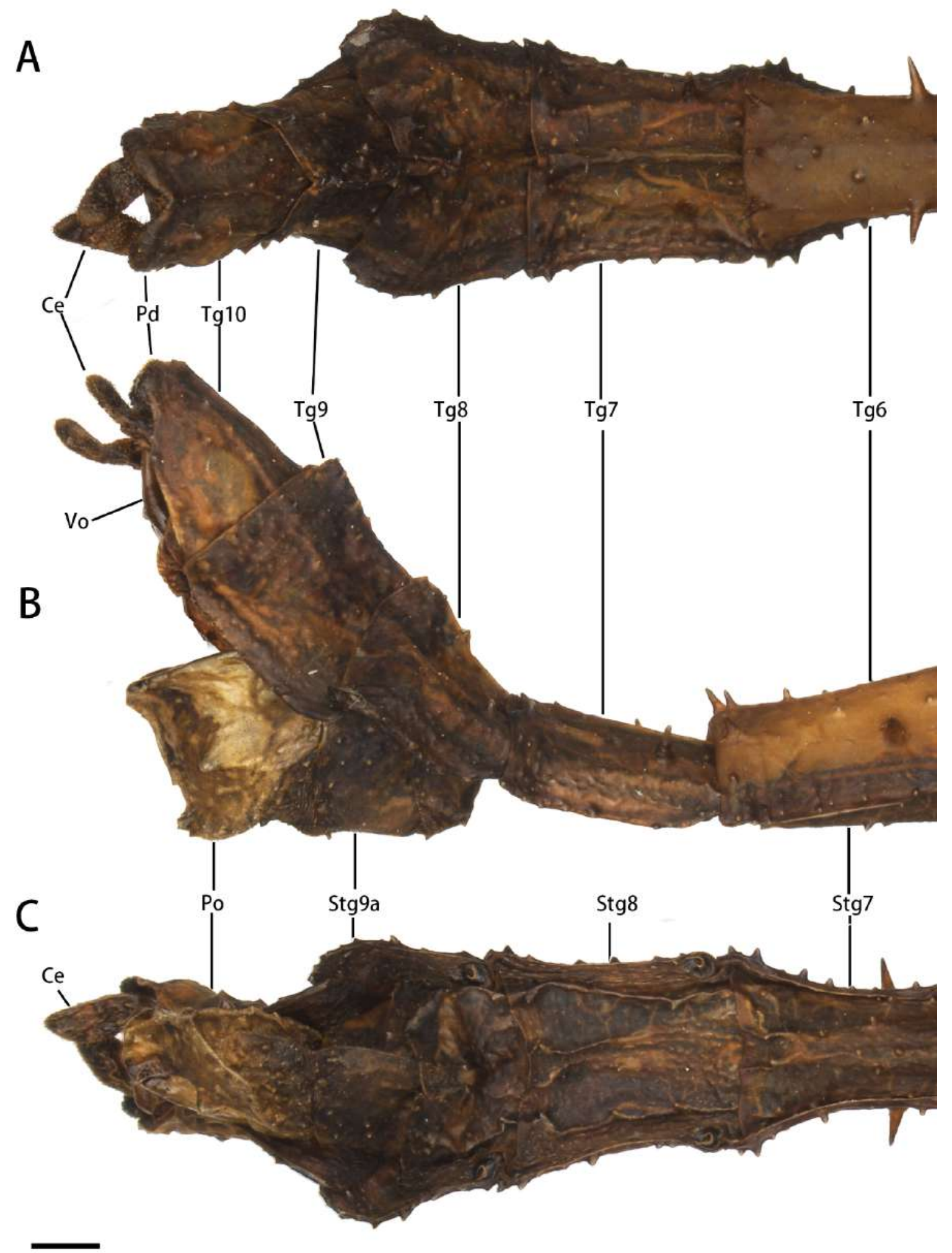

Figura 16:A-C. Morfologia do abdômen e terminália do macho de Ceroys (Ceroys) cristatus: A. Vista dorsal. B. Vista posterior; C. Vista ventral. Abreviações e acrônimos: Ce, cercos; Po, poculum; St, esternitos; St9a, porção anterior do esternito 9; Tg, tergito; Pd, placa dentada; Vo, vômer. Barra de escala: $\mathbf{A}-\mathbf{C}=1 \mathrm{~mm}$. 
A

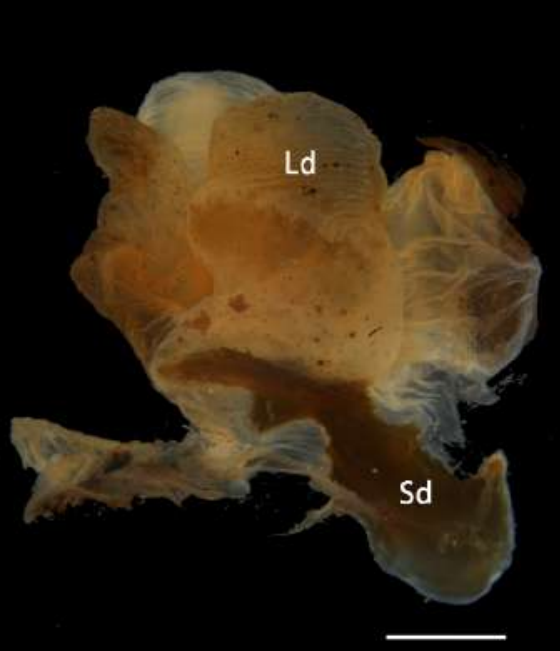

C

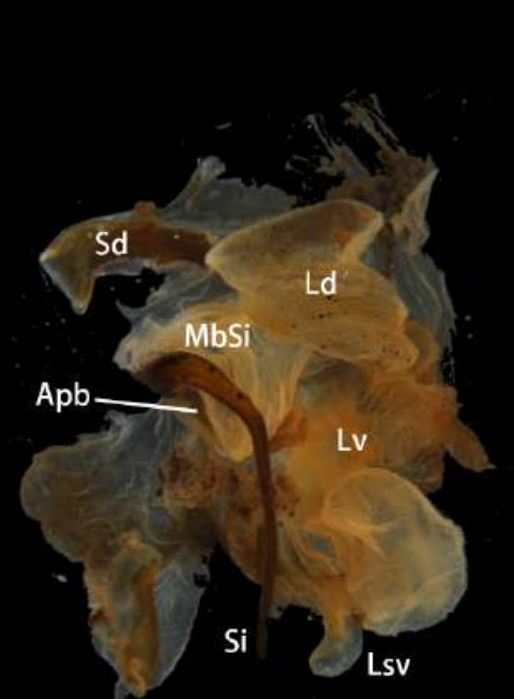

B

D

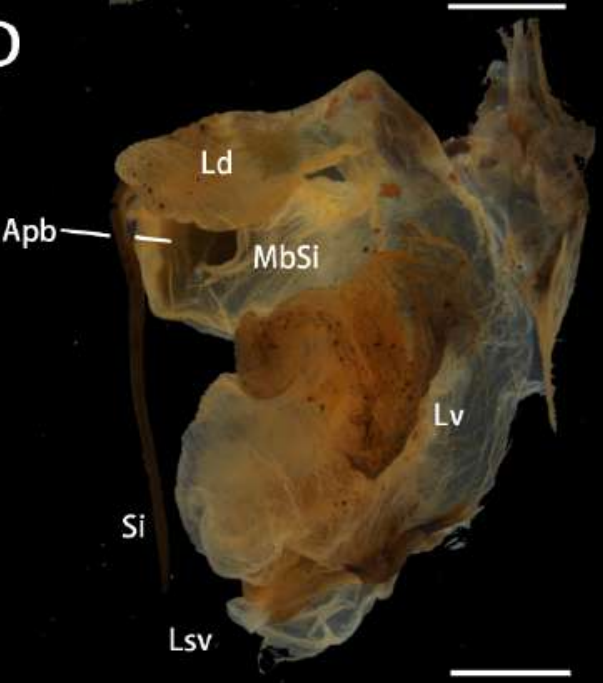

$\mathrm{Pb}$

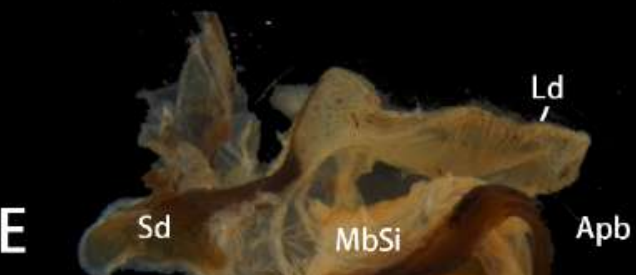

$\mathrm{Si}$

LV

Figura 17:A-E. Morfologia da genitália de Ceroys (Ceroys) cristatus : A. Vista dorsal. B. Vista ventral; C. Vista lateral esquerda; D. Vista lateral direita; E. Vista caudal; Abreviações e acrônimos: Sd, esclerito dorsal; Si, esclerito interno; Ld, lóbulo dorsal; Apb, Apódema basal; Mbsi, Membrana do esclerito interno; Pb, projeção bífida; Lsv, Lóbulo sinuoso ventral; LV, Lóbulo ventral. Barra de escala: $1 \mathrm{~mm}$. 


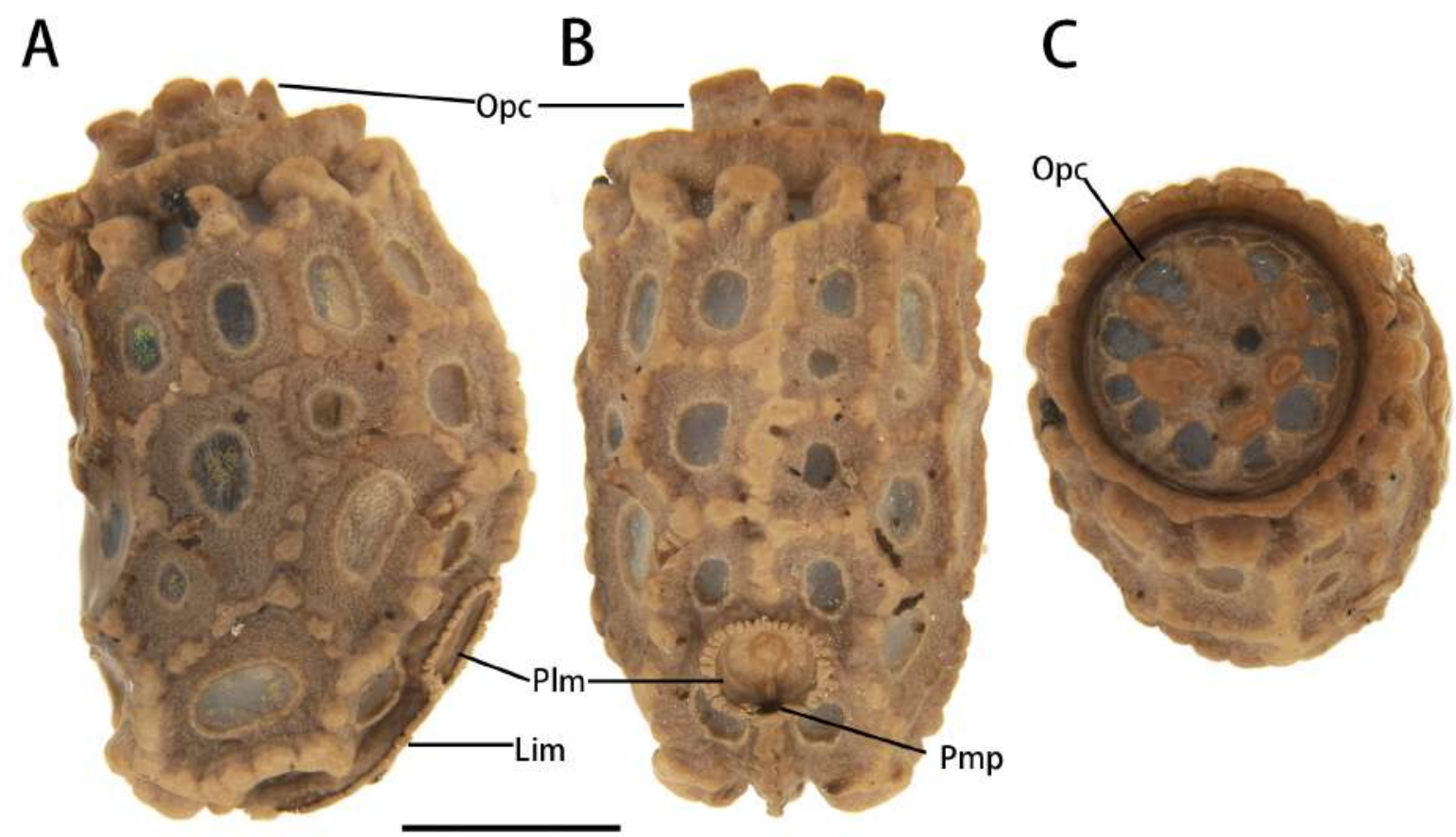

Figura 18: A-C. Ovo de Ceroys (Ceroys) cristatus: A. Vista lateral. B. Vista dorsal. C. Vista anterior. Abreviações e acrônimos: Pmp, poro micropilar; PIm, placa micropilar; Lim, linha mediana; Opc, opérculo. Barra de escala: $1 \mathrm{~mm}$.

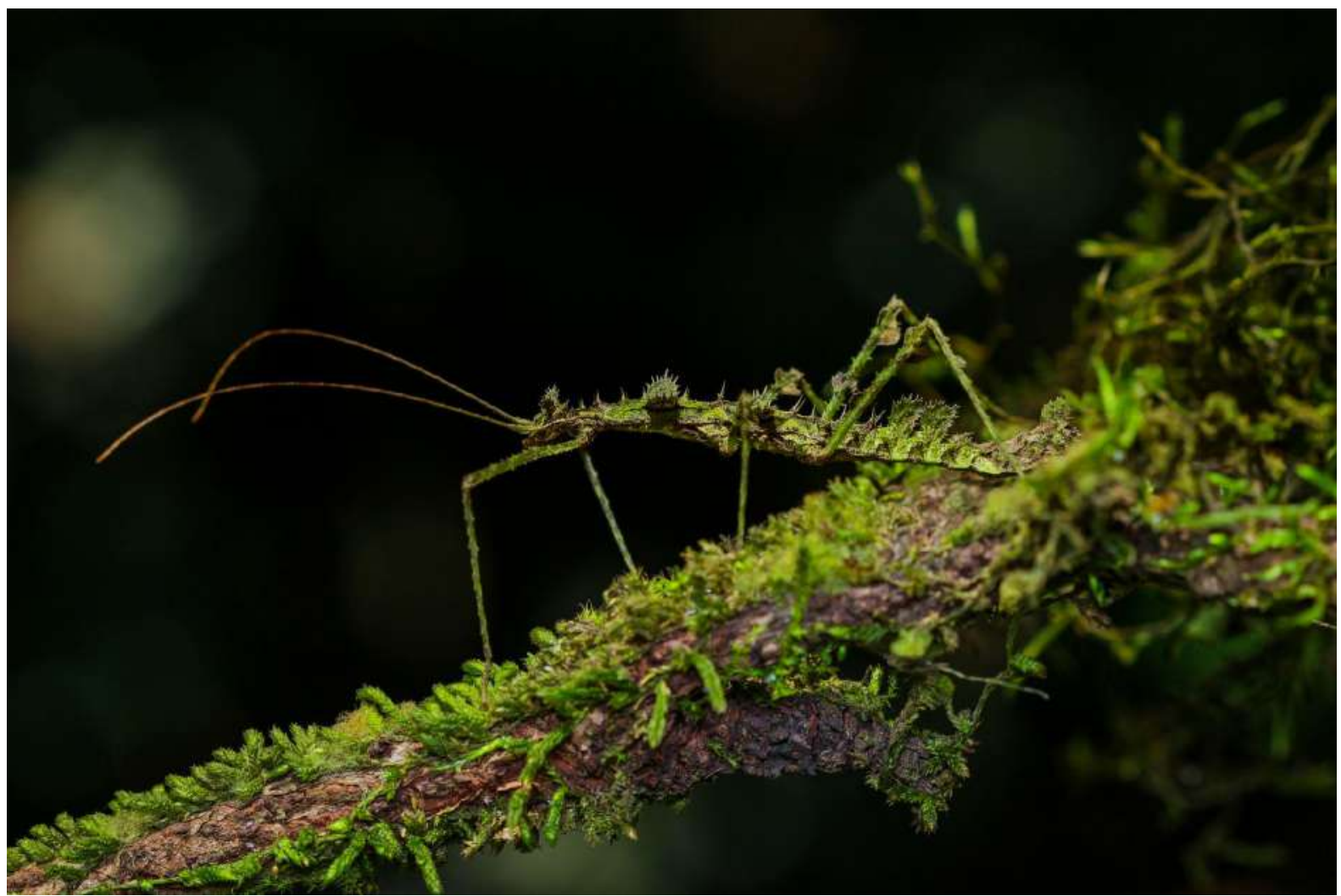

Figura 19: Fêmea adulta de Ceroys (Ceroys) cristatus in situ. Foto de Phillip Watzke Engelking - Parque Nacional do Itatiaia, Rio de Janeiro, Brasil. Foto fora de escala. 


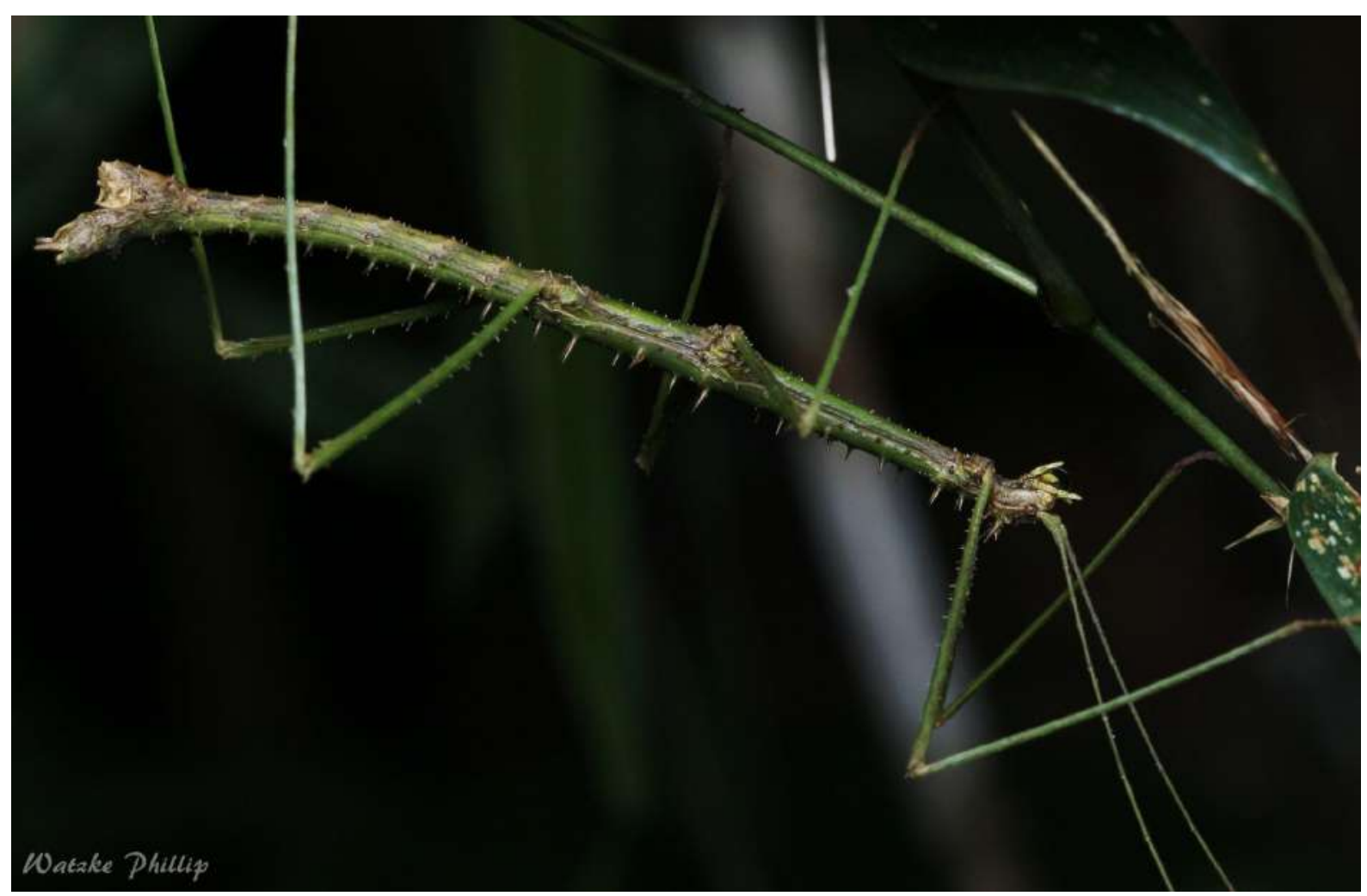

Figura 20: Macho adulto de Ceroys (Ceroys) cristatus in situ. Foto realizada por Phillip Watzke Engelking no Parque Nacional do Itatiaia, Rio de Janeiro, Brasil. Foto fora de escala. 


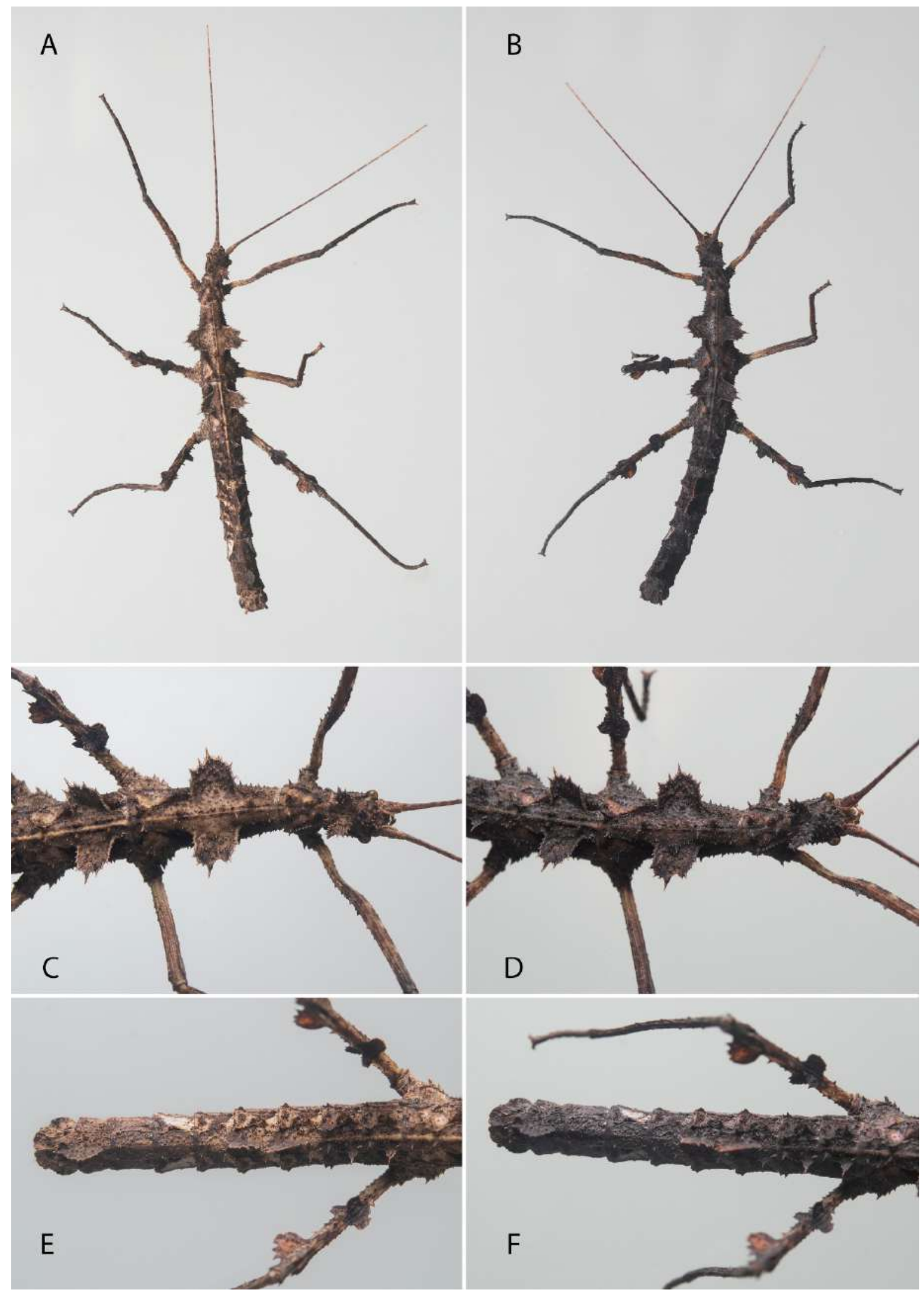

Figura 21: Variação de cor em um mesmo indivíduo de Ceroys (Ceroys) cristatus de acordo com variações de luminosidade ambiente ex situ. Indivíduo foi mantido em diferentes regimes de iluminação para testar a resposta de mudança de cor a estímulos ambientais. $\mathbf{A}, \mathbf{C}$ e E: Coloração após repousar em ambiente iluminado por luz solar direta. B, D e F: Coloração após repousar em ambiente completamente desprovido de luminosidade. 

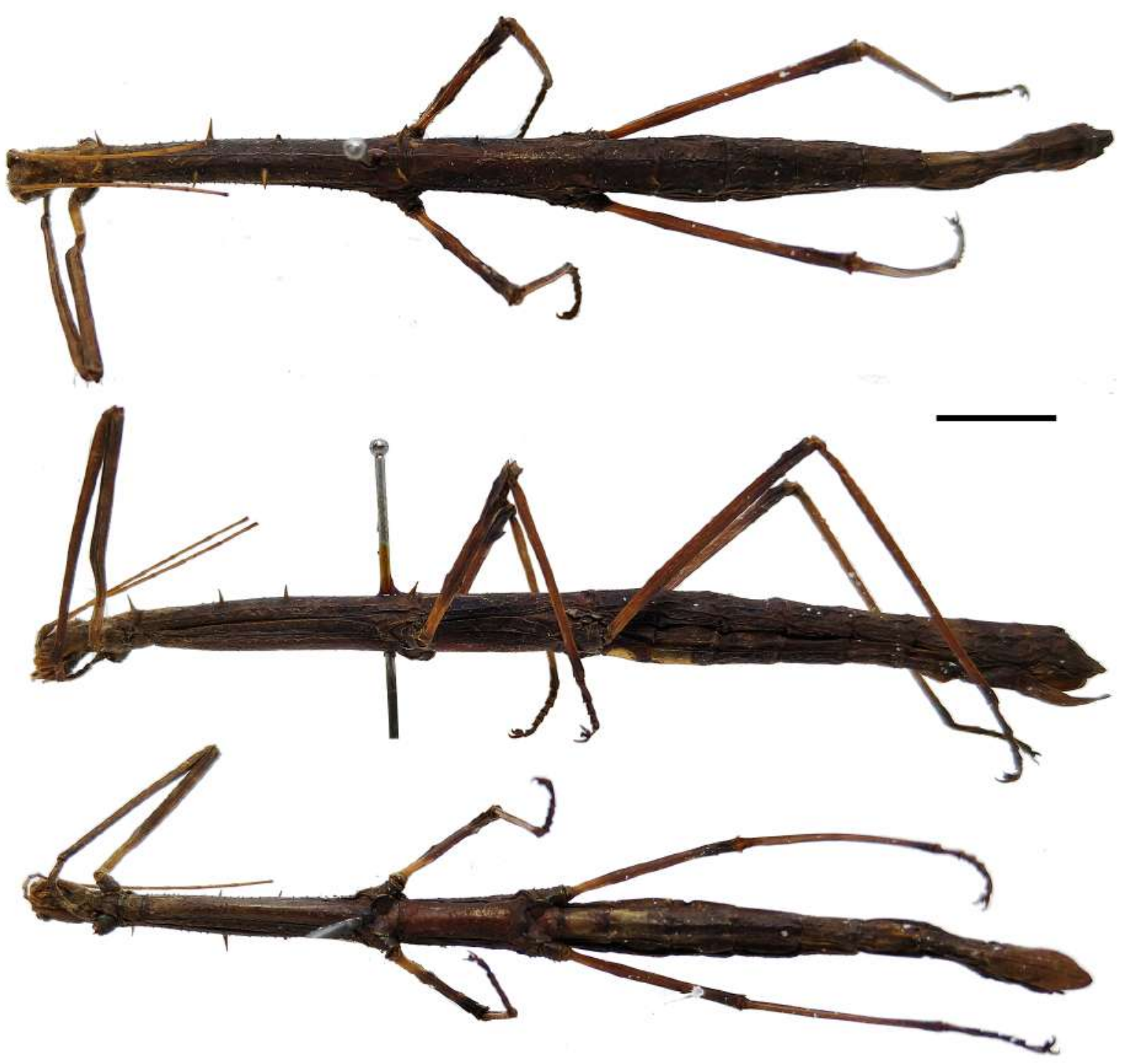

Figura 22: Holótipo de Ceroys scaber. Fêmea adulta de Canuleius scaber comb. nov. em vista dorsal, lateral e ventral. Barra de escala $=10 \mathrm{~mm}$. 

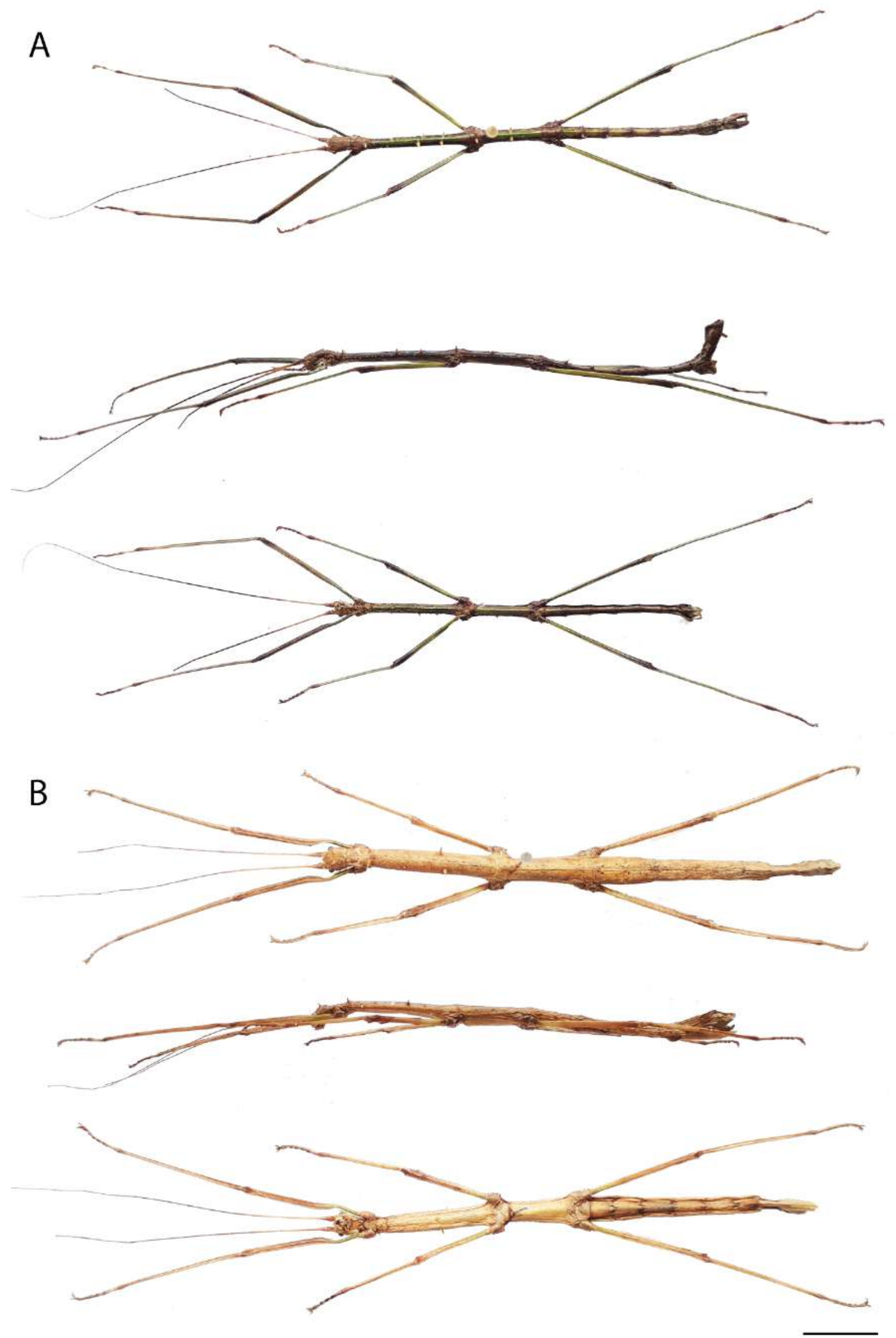

Figura 23: Macho e fêmea adultos de Canuleius scaber comb. nov. A. Macho adulto em vista dorsal, lateral e ventral B. Fêmea adulta em vista dorsal, lateral e ventral. Barra de escala: $10 \mathrm{~mm}$. 

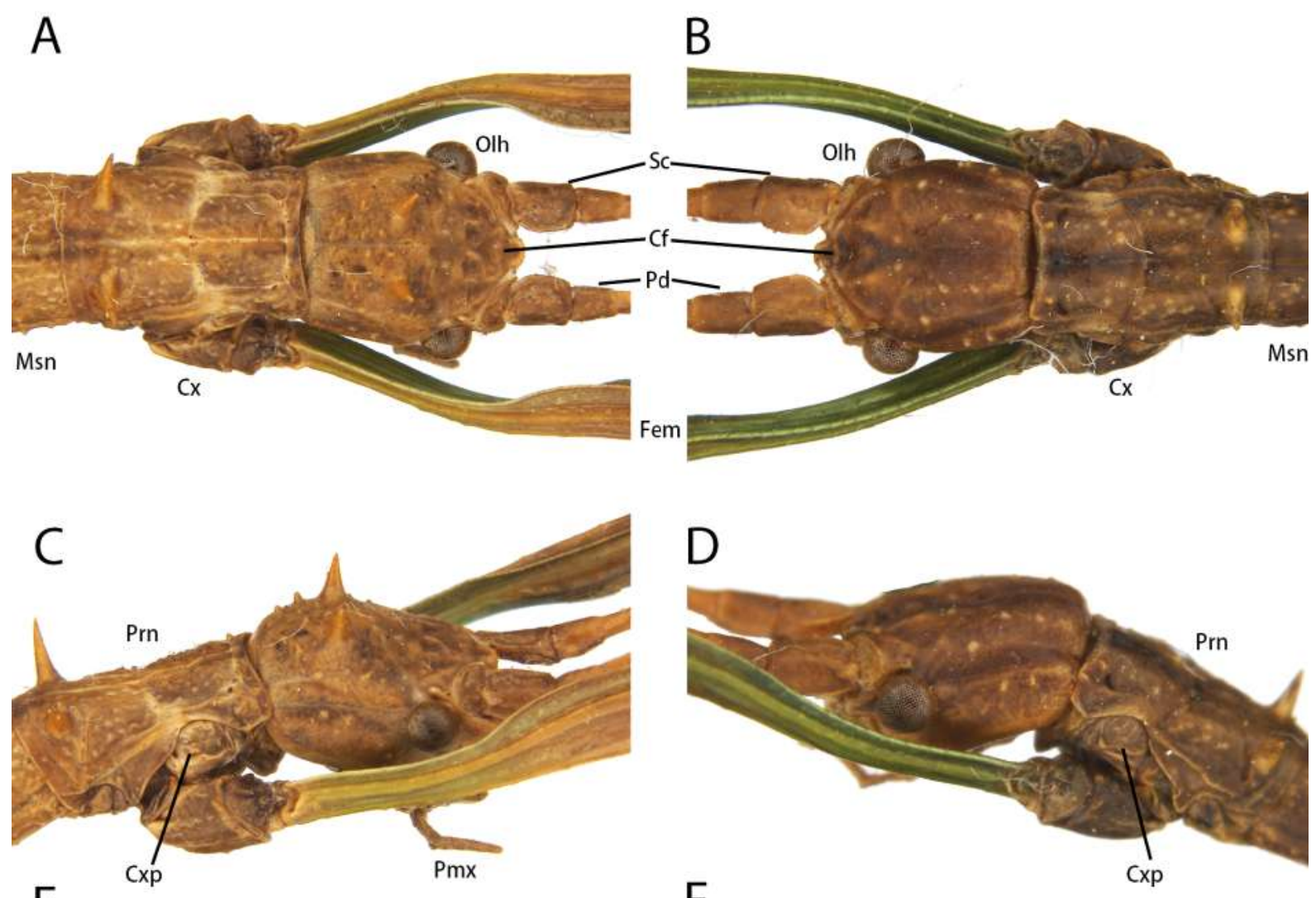

D

$\mathrm{E}$

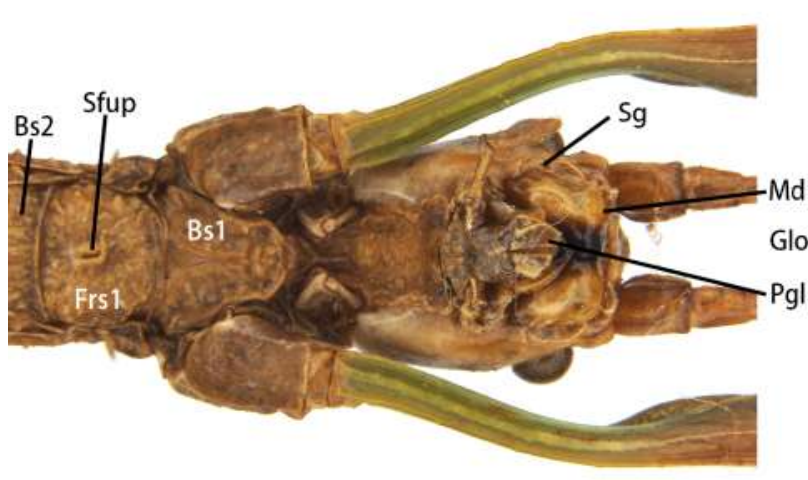

$\mathrm{F}$
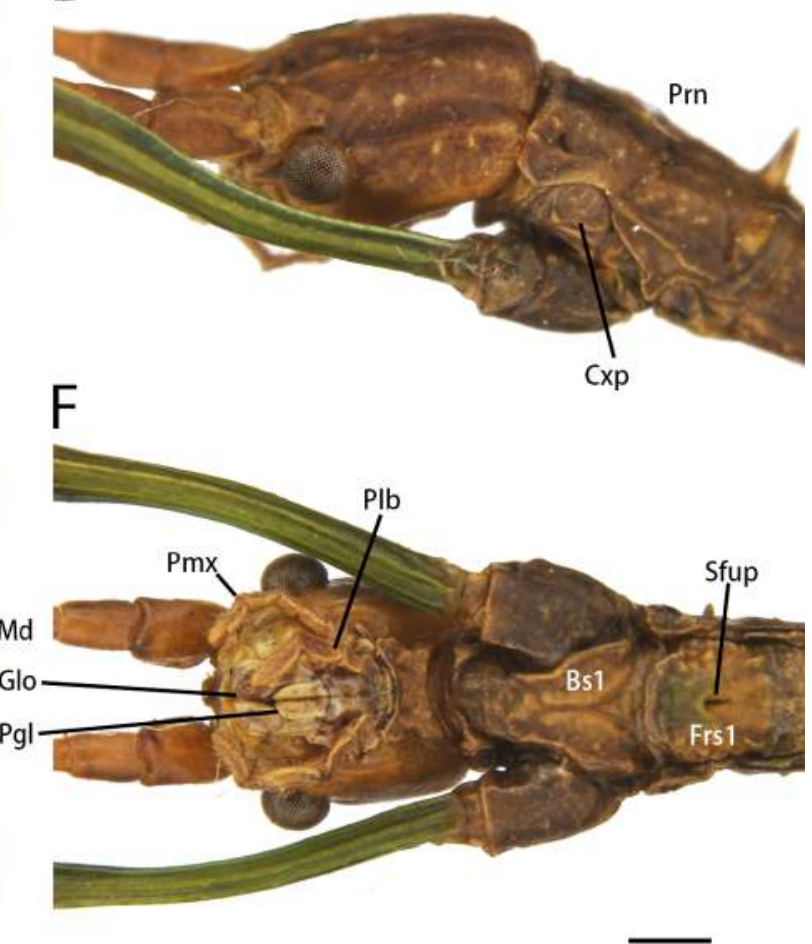

Figura 24: A-F. Detalhe da cabeça de Canuleius scaber comb. nov. A, C, E. Fêmea adulta: A. Vista dorsal; C. Vista lateral; E. Vista ventral. B, D, E. Macho adulto: B. Vista dorsal; D. Vista lateral; F. Vista ventral. Abreviações e acrônimos: Ant, antenômero; Bs1-Bs2, basisterno pro- e mesotorácico; Cx, coxa; Cxp, coxopleurito; Olh, olho; Cf, Convexidade frontal; Fem, fêmur; Frs1, furcasternito protorácico; Sf, sutura frontal; Gl, glossa; Md, mandíbula; Msn, mesonoto; Pd, pedicelo; Pgl, paraglossa; Plb, Palpo labial; Pmx, palpo maxilar; Prn, pronoto; Sc, escapo; Sg, subgena; Sfup, sulco furcasternal. Barra de escala: 1 $\mathrm{mm}$ 

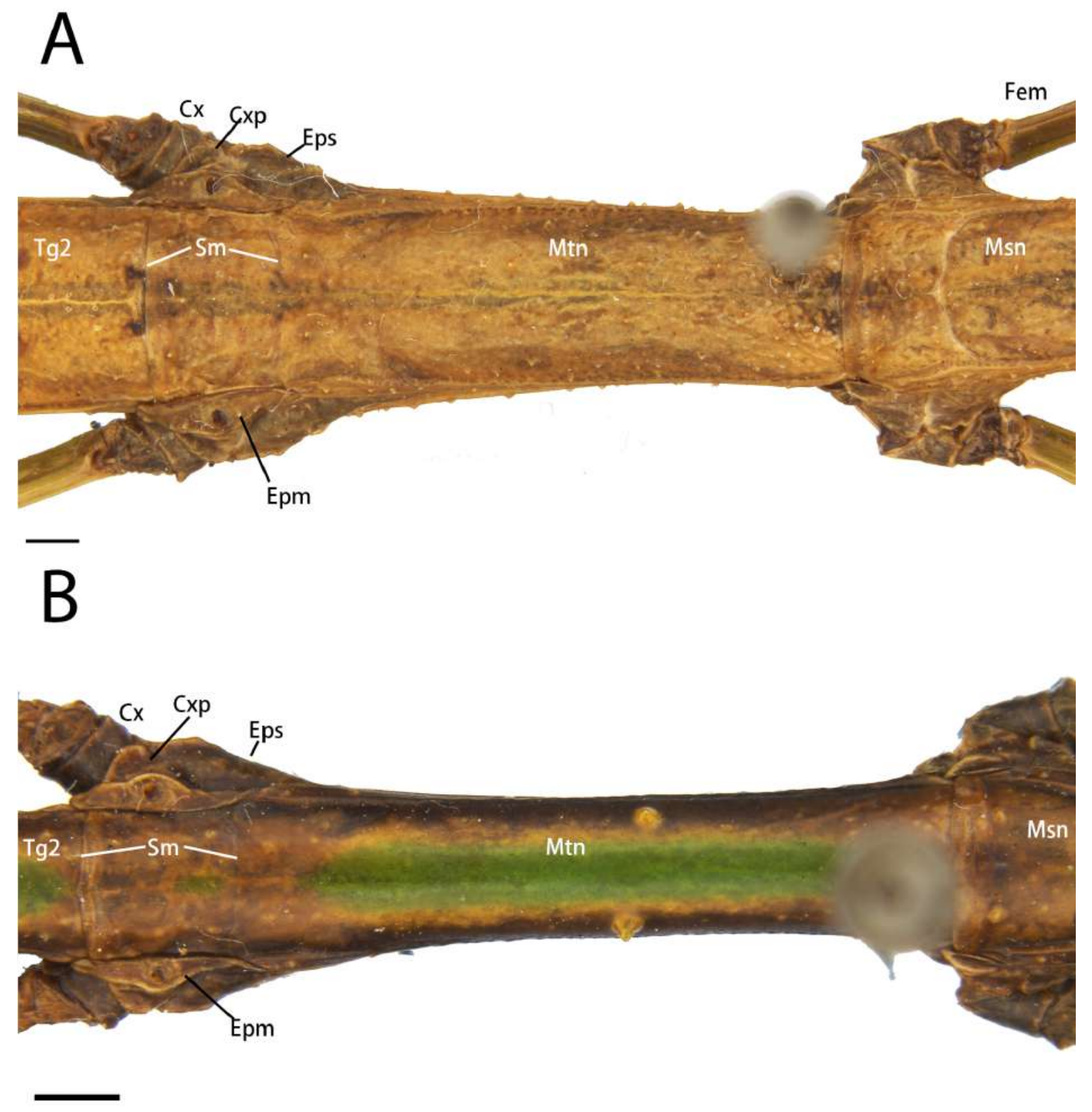

Figura 25: A-B. Morfologia do metatórax de Canuleius scaber comb. nov. em vista dorsal. A. Fêmea B. Macho. Abreviações e acrônimos: Cx, coxa; Cxp, coxopleurito; Epm, epímeron; Eps, episterno; Sm, segmento mediano; Msn, mesonoto; Mtn, metanoto; Tg, tergito; Fem, fêmur. Barra de escala: $1 \mathrm{~mm}$. 


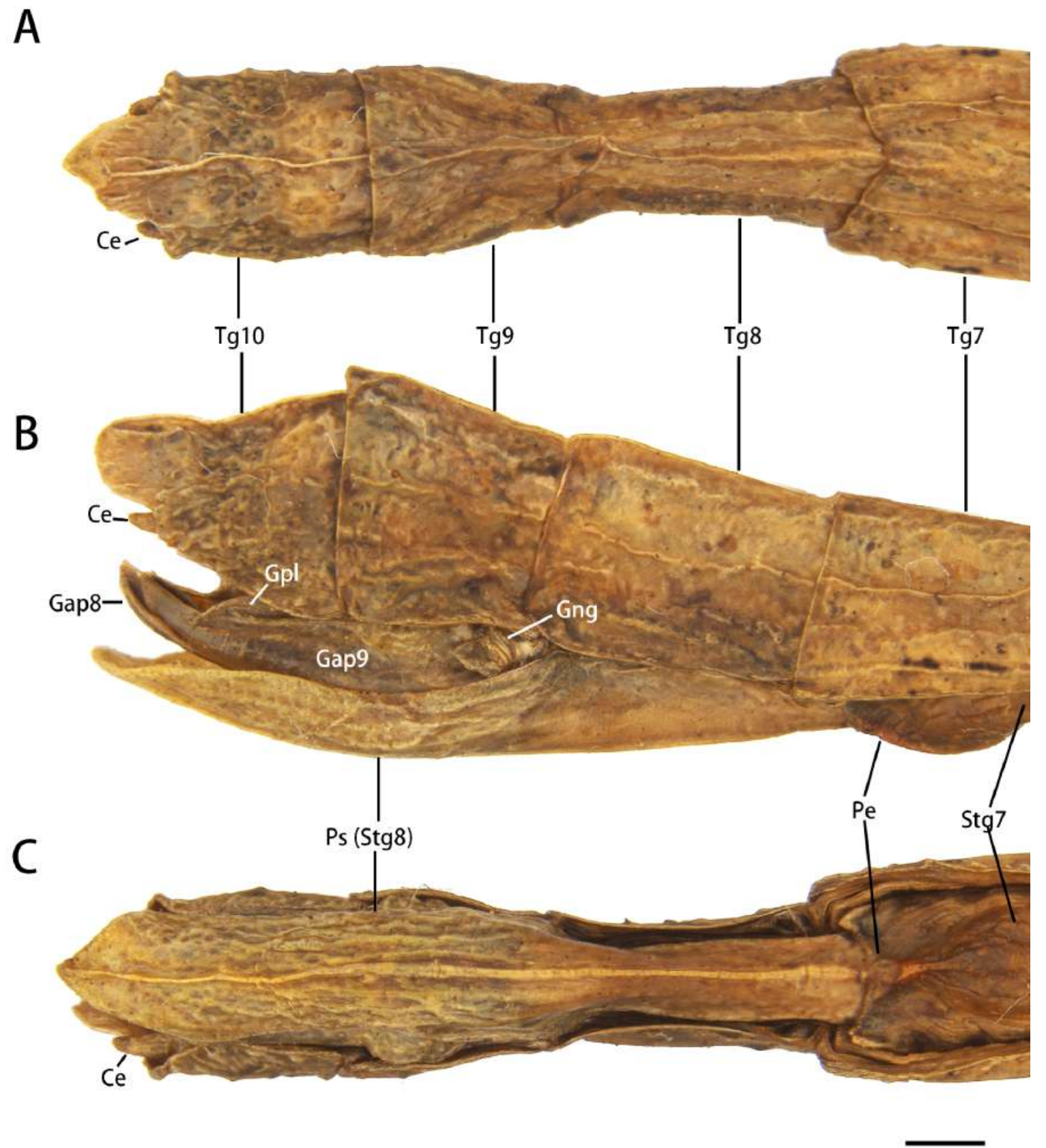

Figura 26:A-C. Morfologia do abdômen e terminália da fềmea de Canuleius scaber comb. nov. A. Vista dorsal. B. Vista lateral; C. Vista ventral; Abreviações e acrônimos: Ce, cercos; Gap8-Gap9, gonapófise 8 e 9; Gng, gonângulo; Gpl, gonoplaca; Pe, órgão pré-opercular; Ps, Placa subgenital; St, esternito; Tg, tergito. Barra de escala: $1 \mathrm{~mm}$. 


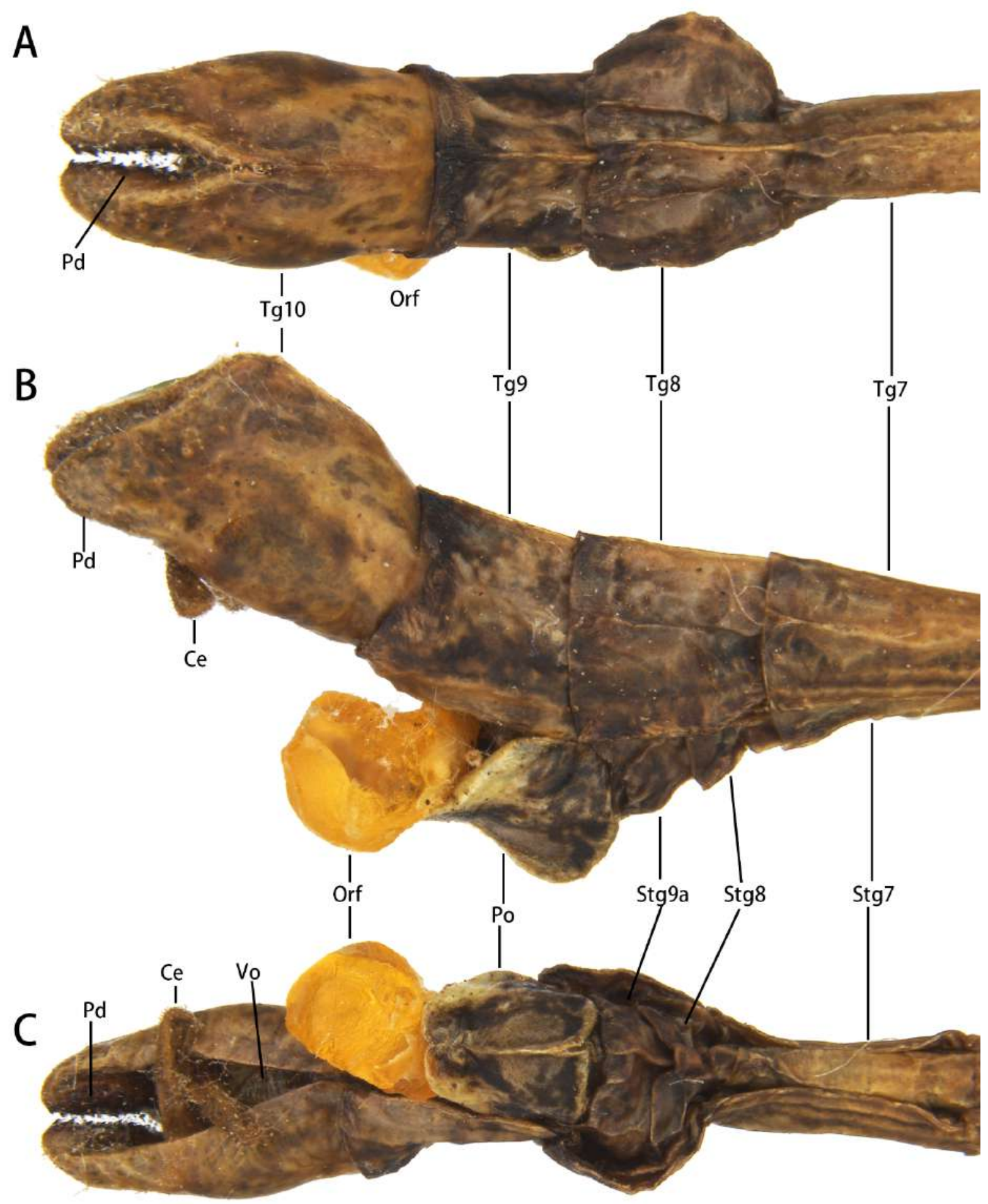

Figura 27:A-C. Morfologia do abdômen e terminália do macho de Canuleius scaber comb. nov.: A. Vista dorsal. B. Vista posterior; C. Vista ventral. Abreviações e acrônimos: Ce, cercos; Po, poculum; St, esternitos; St9a, porção anterior do esternito 9; Tg, tergito; Pd, placa dentada; Vo, vômer; Orf, Órgão fálico. Barra de escala: $\mathbf{A}-\mathbf{C}=1 \mathrm{~mm}$. 


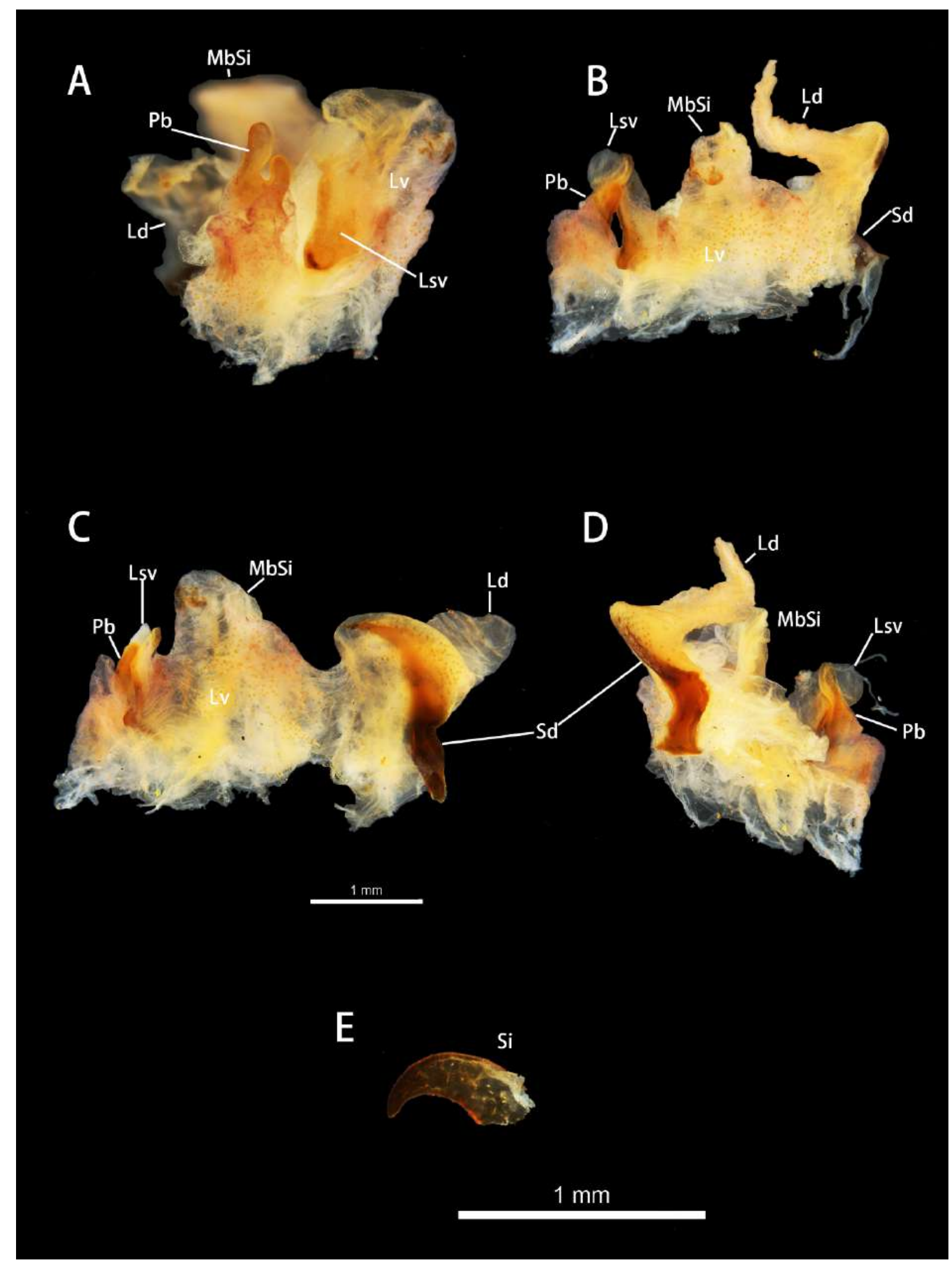

Figura 28: A-E. Morfologia da genitália de Canuleius scaber comb. nov.: A. Vista dorsal. B. Vista ventral; C. Vista lateral esquerda; D. Vista lateral direita; E. Detalhe do esclerito interno; Abreviações e acrônimos: Sd, esclerito dorsal; Si, esclerito interno; Ld, lóbulo dorsal; Apb, Apódema basal; Mbsi, Membrana do esclerito interno; Pb, projeção bífida; Lsv, Lóbulo sinuoso ventral; LV, Lóbulo ventral. Barra de escala: $1 \mathrm{~mm}$. 


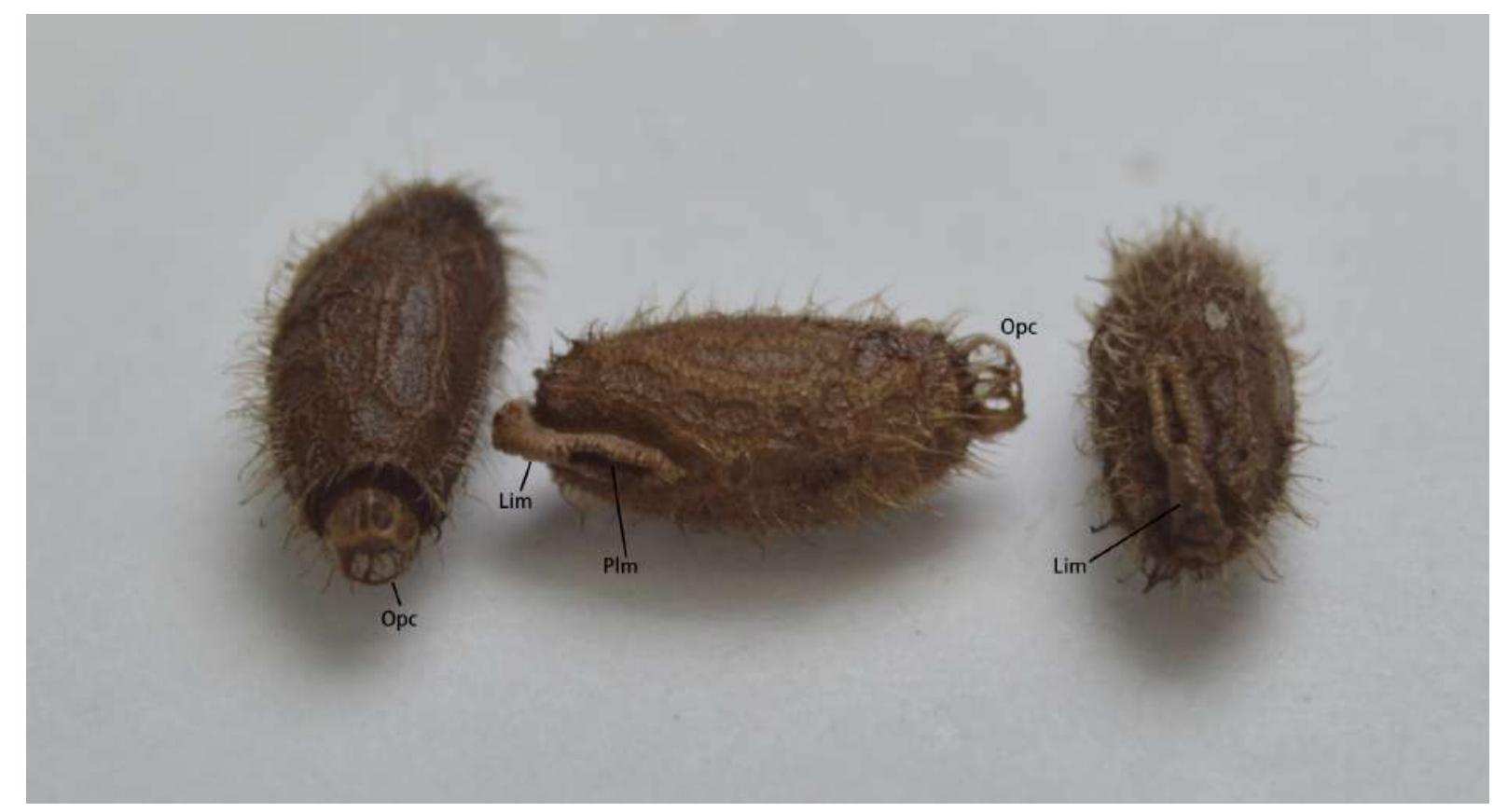

Figura 29: Ovo de Canuleius scaber comb. nov. fotografados ex situ. Imagens fora de escala. 

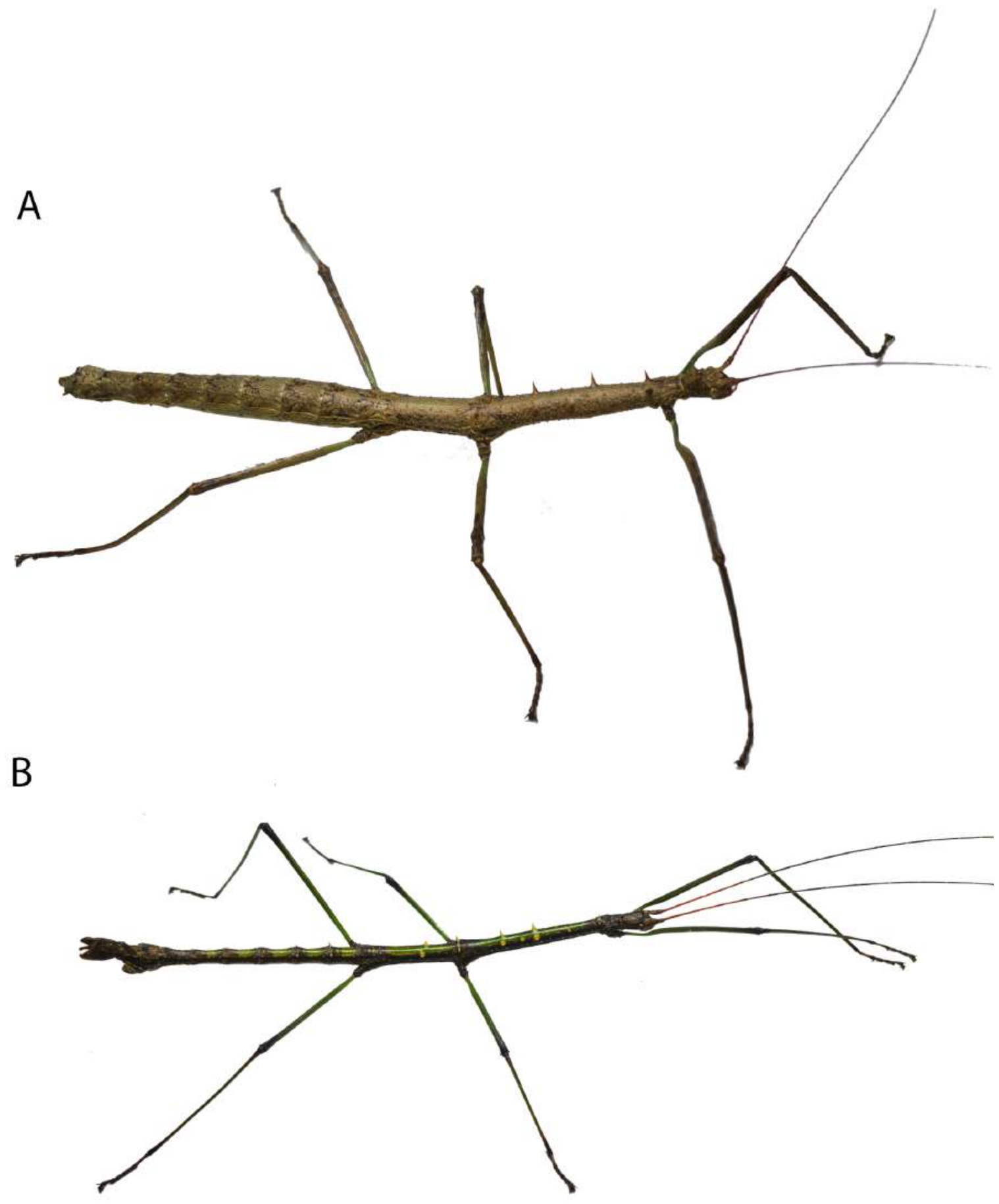

Figura 30: Macho e fêmea adultos de Canuleius scaber comb. nov. vivos ex situ. A. Fêmea adulta, B, Macho adulto. 


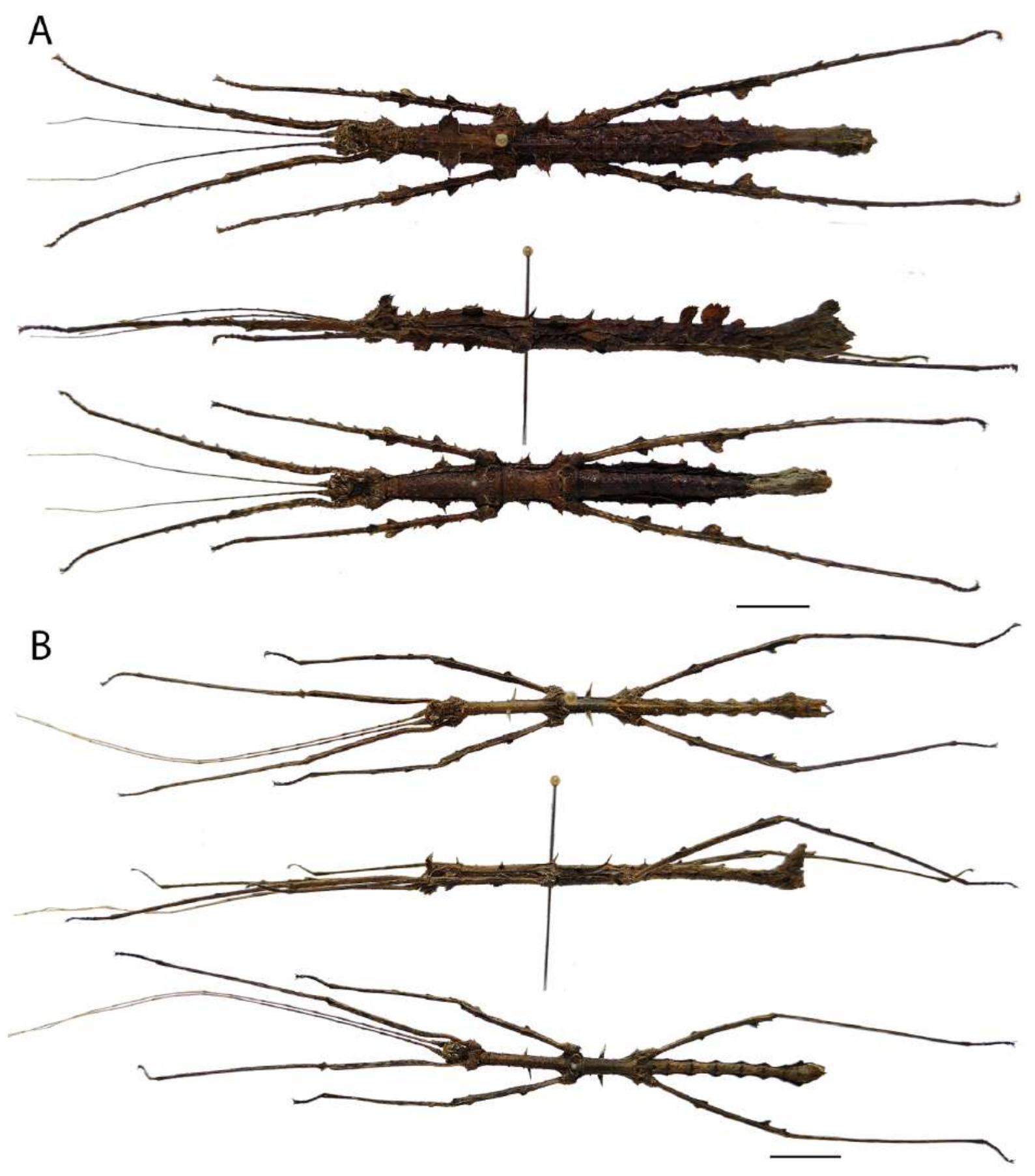

Figura 31: Macho e fêmea adultos de Ceroys (Miroceroys) heymonsi. A.Fêmea adulta em vista dorsal, lateral e ventral B. Macho adulto em vista dorsal, lateral e ventral. Barra de escala: $10 \mathrm{~mm}$. 


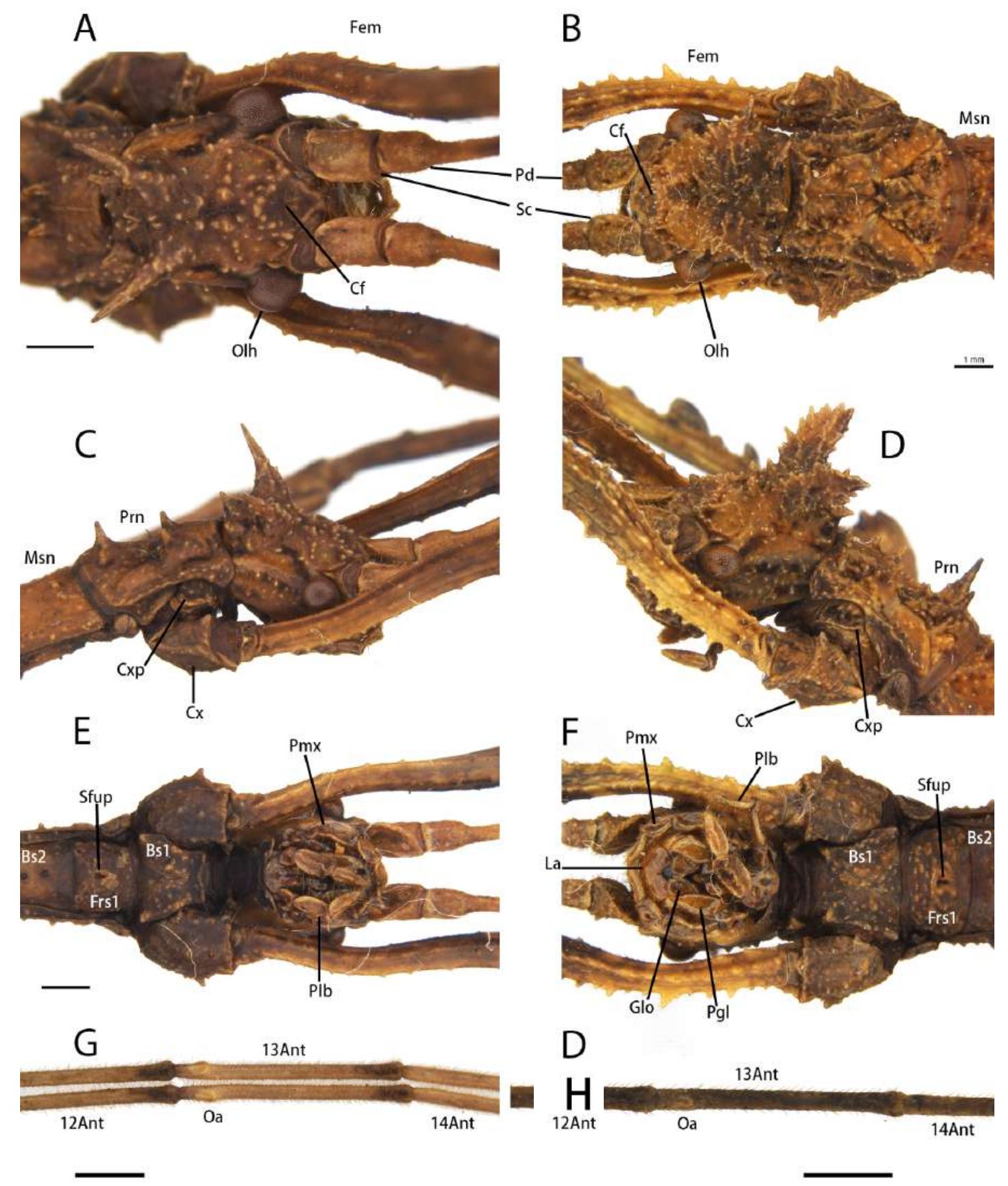

Figura 32: A-F. Detalhe da cabeça de Ceroys (Miroceroys) heymonsi. A, C, E. Macho adulto: A. Vista dorsal; C. Vista lateral; E. Vista ventral. B, D, E. Fêmea adulta: B. Vista dorsal; D. Vista lateral; F. Vista ventral, G, H. Detalhe das antenas mostrando o órgão antenal do macho $(\mathbf{G})$ e fêmea $(\mathbf{H})$. Abreviações e acrônimos: Ant, antenômero; Bs1-Bs2, basisterno pro- e mesotorácico; $\mathbf{C x}$, coxa; $\mathbf{C x p}$, coxopleurito; Olh, olho; Cf, Convexidade frontal; Fem, fêmur; Frs1, furcasternito protorácico; Gl, glossa; Msn, mesonoto; Pd, pedicelo; Pgl, paraglossa; Plb, Palpo labial; Pmx, palpo maxilar; Prn, pronoto; Sc, escapo; Sg, subgena; Sfup, sulco furcasternal; Oa, órgão antenal. Barra de escala: $1 \mathrm{~mm}$ 


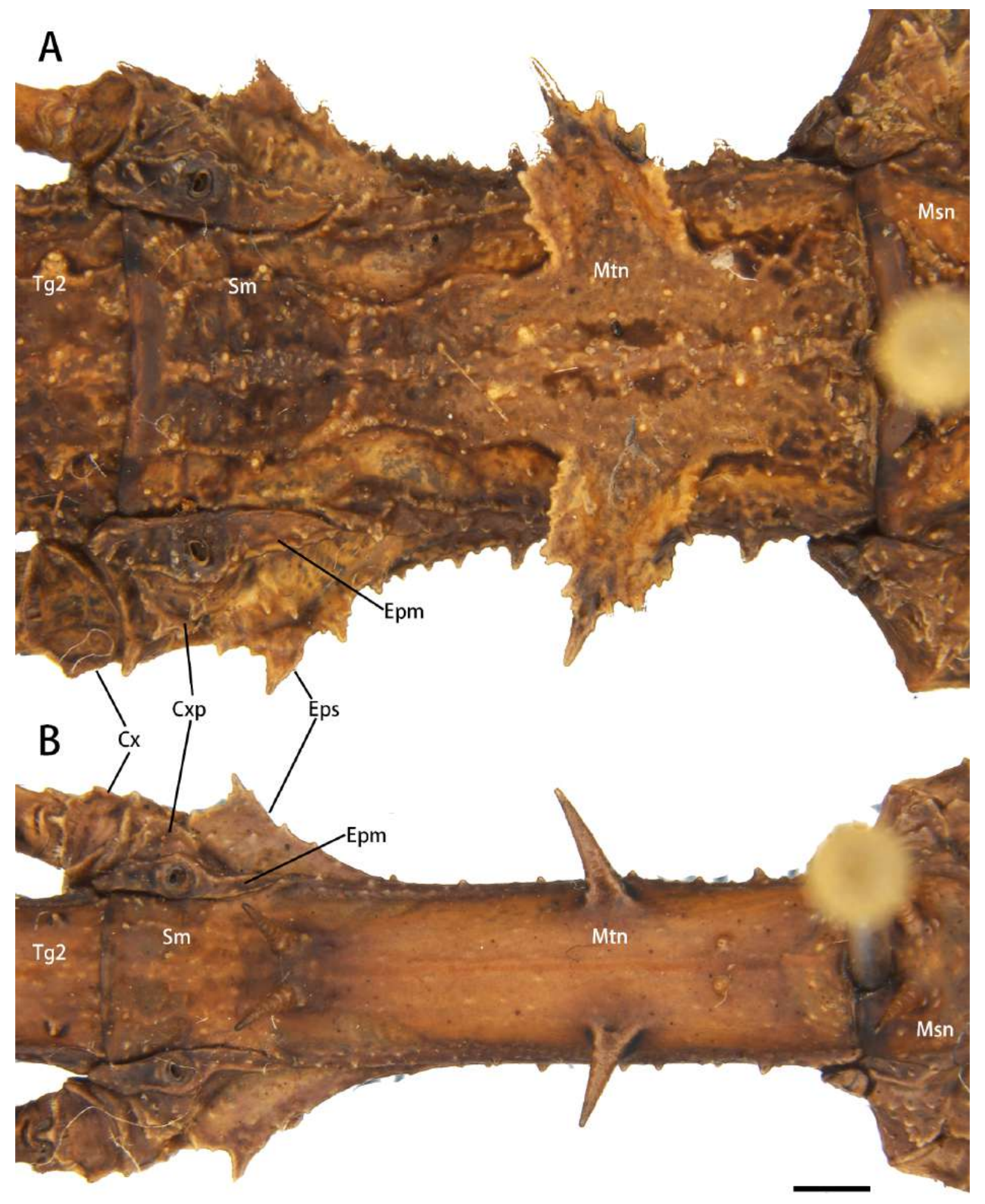

Figura 33: A-B. Morfologia do metatórax de Ceroys (Miroceroys) heymonsi em vista dorsal. A. Fêmea B. Macho. Abreviações e acrônimos: Cx, coxa; Cxp, coxopleurito; Epm, epímeron; Eps, episterno; Sm, segmento mediano; Msn, mesonoto; Mtn, metanoto; Tg, tergito; Fem, fêmur. Barra de escala: $1 \mathrm{~mm}$. 
A

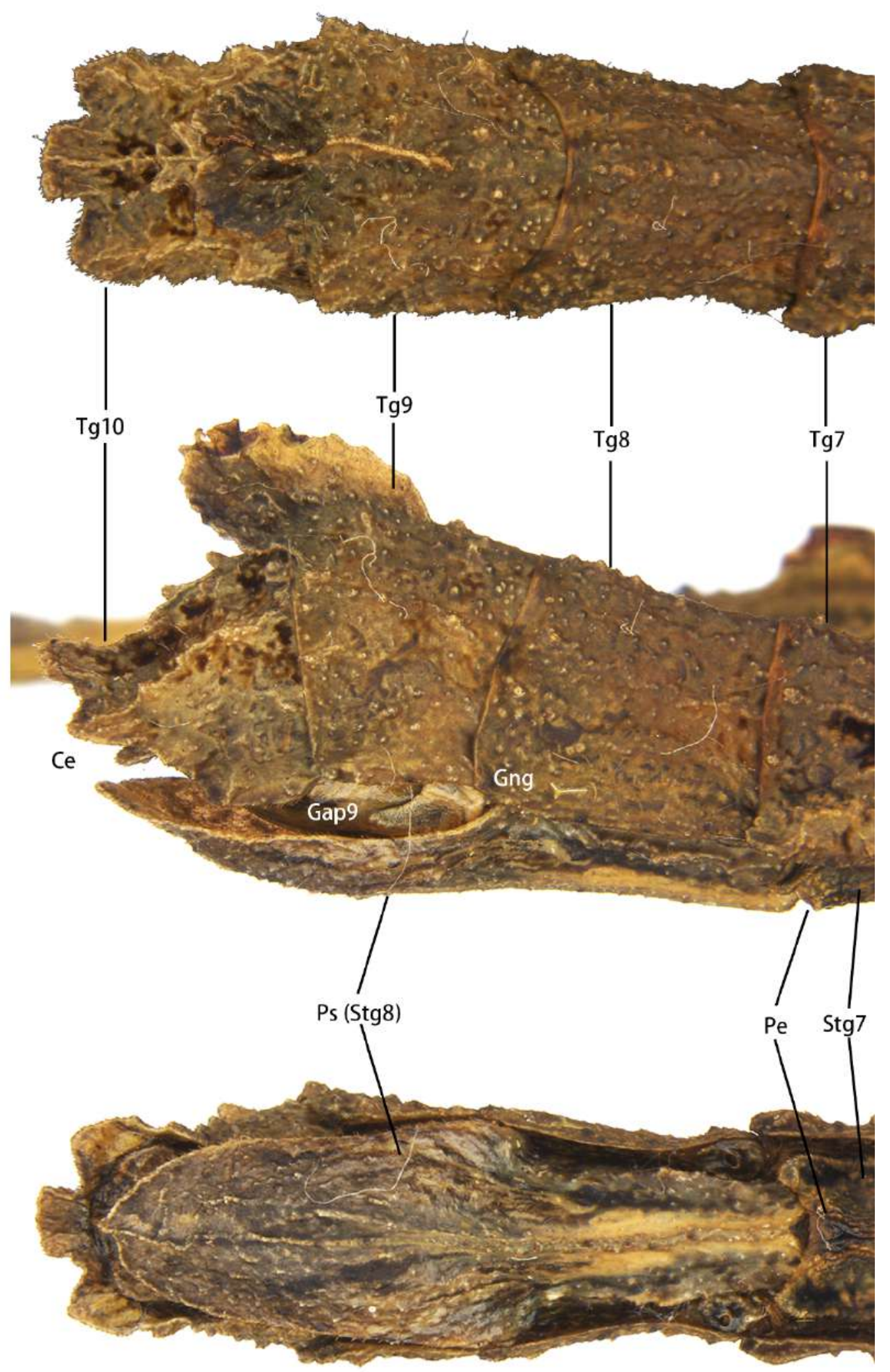

Figura 34:A-C. Morfologia do abdômen e terminália da fêmea de Ceroys (Miroceroys) heymonsi. A. Vista dorsal. B. Vista lateral; C. Vista ventral; Abreviações e acrônimos: Ce, cercos; Gap9, gonapófise 8 e 9; Gng, gonângulo; Pe, órgão pré-opercular; Ps, Placa subgenital; St, esternito; Tg, tergito. Barra de escala: $1 \mathrm{~mm}$. 


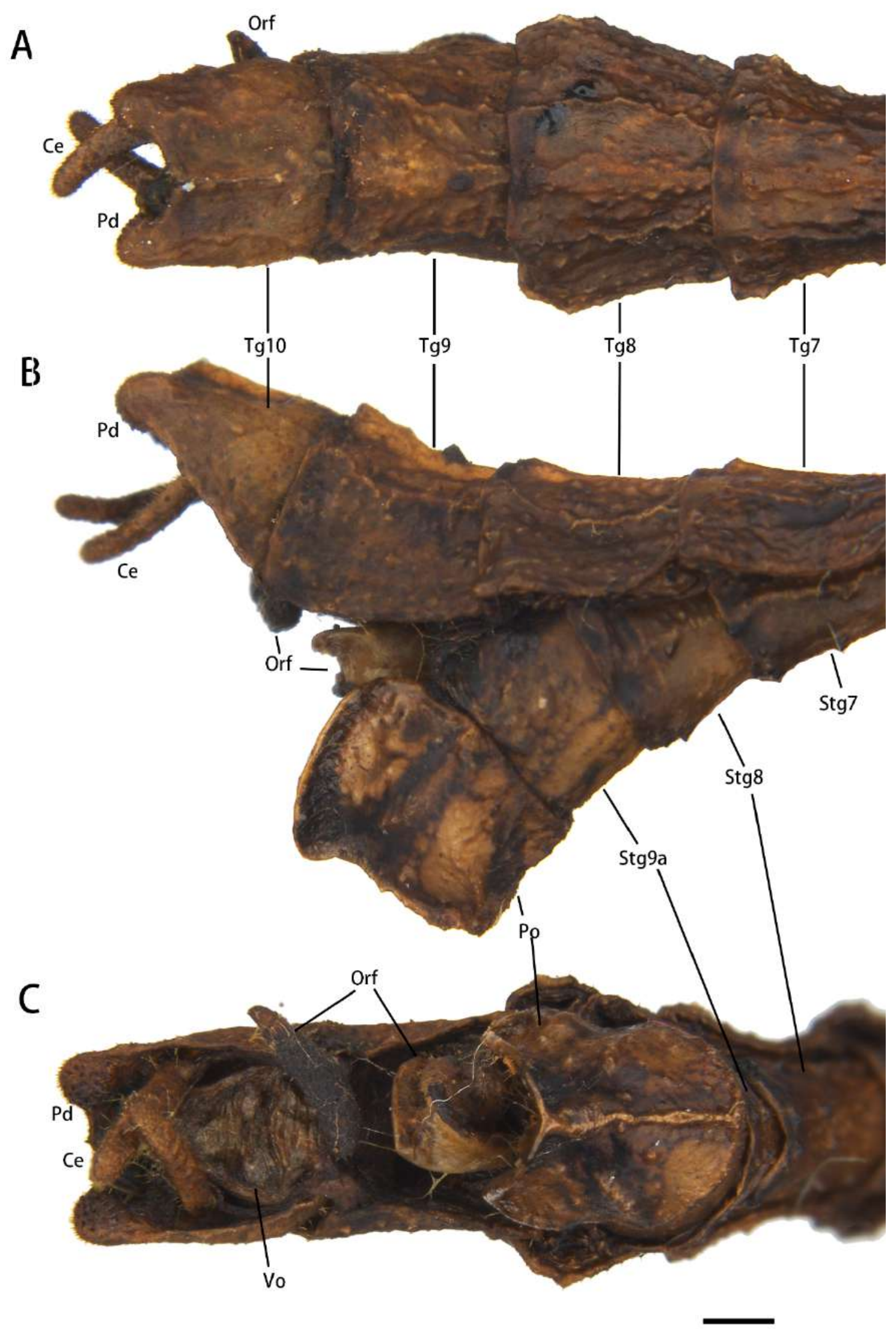

Figura 35:A-C. Morfologia do abdômen e terminália do macho de Ceroys (Miroceroys) heymonsi: A. Vista dorsal. B. Vista posterior; C. Vista ventral. Abreviações e acrônimos: Ce, 
cercos; Po, poculum; St, esternitos; St9a, porção anterior do esternito 9; Tg, tergito; Pd, placa dentada; Vo, vômer; Orf, Órgão fálico. Barra de escala: $\mathbf{A}-\mathbf{C}=1 \mathrm{~mm}$.

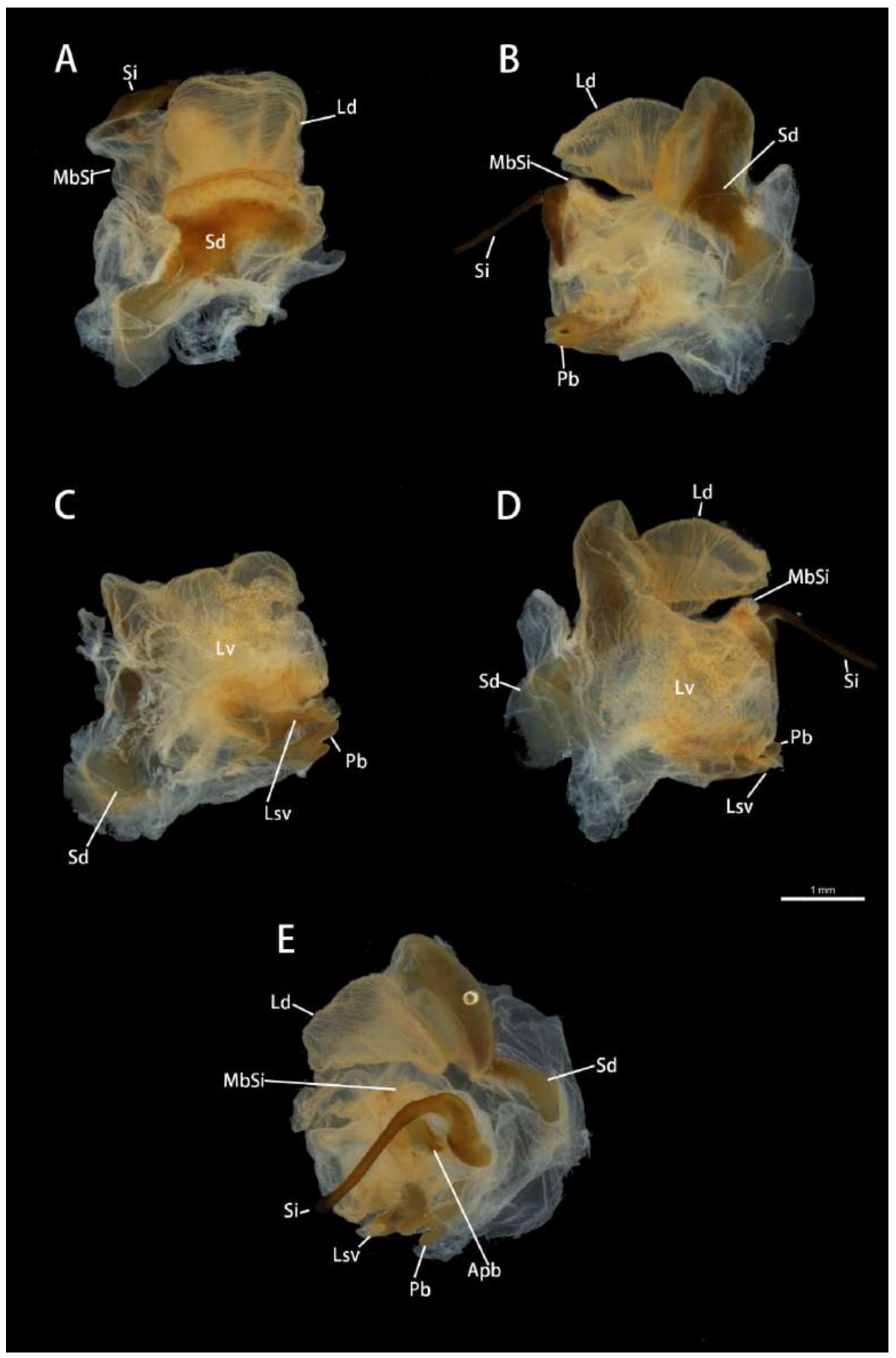

Figura 36: A-E. Morfologia da genitália masculina de Ceroys (Miroceroys) heymonsi: A. Vista dorsal. B. Vista ventral; C. Vista lateral esquerda; D. Vista lateral direita; E. Vista caudal; Abreviações e acrônimos: Sd, esclerito dorsal; Si, esclerito interno; Ld, lóbulo dorsal; Apb, Apódema basal; Mbsi, Membrana do esclerito interno; Pb, projeção bífida; Lsv, Lóbulo sinuoso ventral; LV, Lóbulo ventral. Barra de escala: $1 \mathrm{~mm}$. 

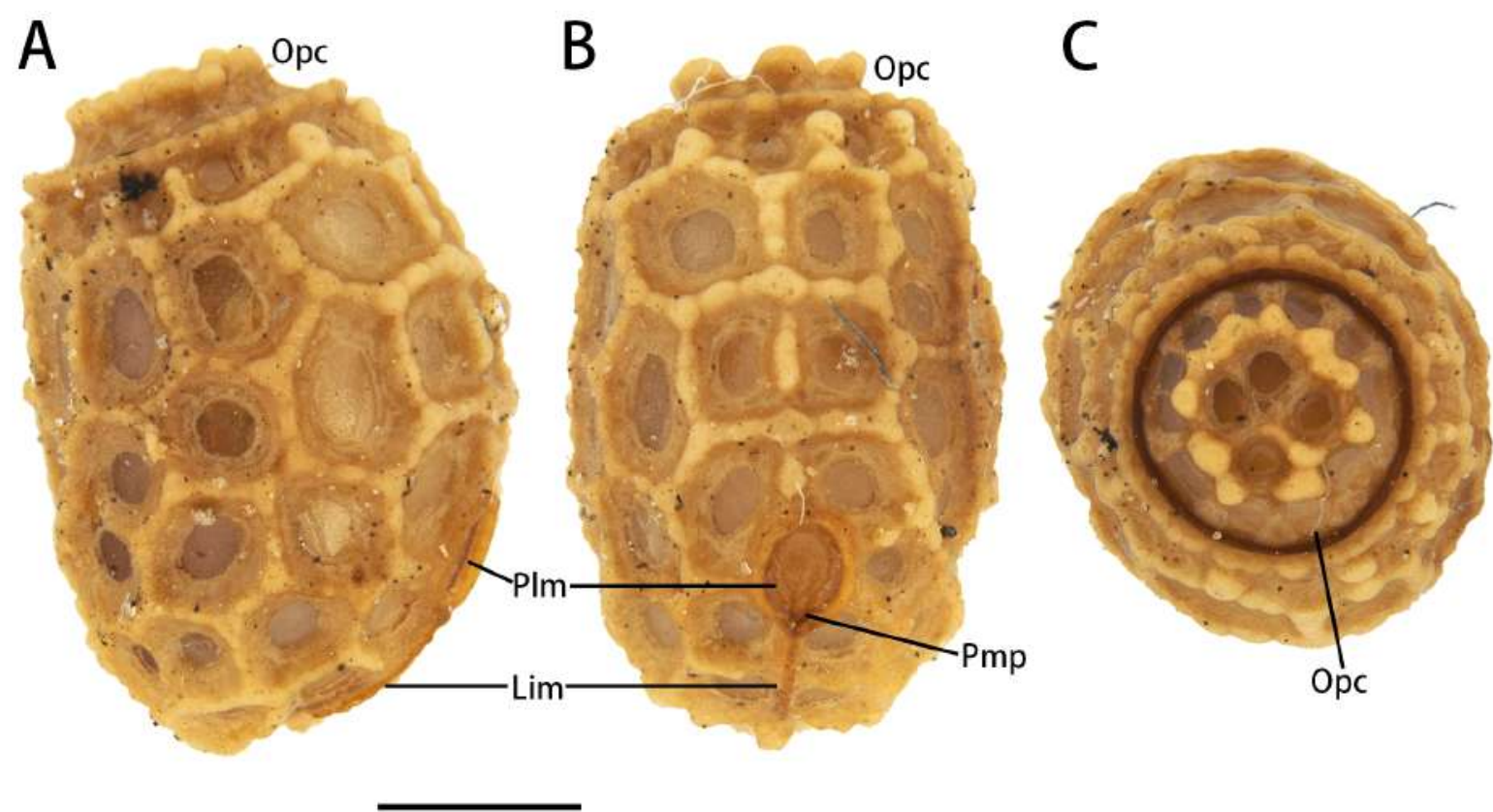

Figura 37: A-C. Ovo de Ceroys (Miroceroys) heymonsi: A. Vista lateral. B. Vista dorsal. C. Vista anterior. Abreviações e acrônimos: Pmp, poro micropilar; PIm, placa micropilar; Lim, linha mediana; Opc, opérculo. Barra de escala: $1 \mathrm{~mm}$.

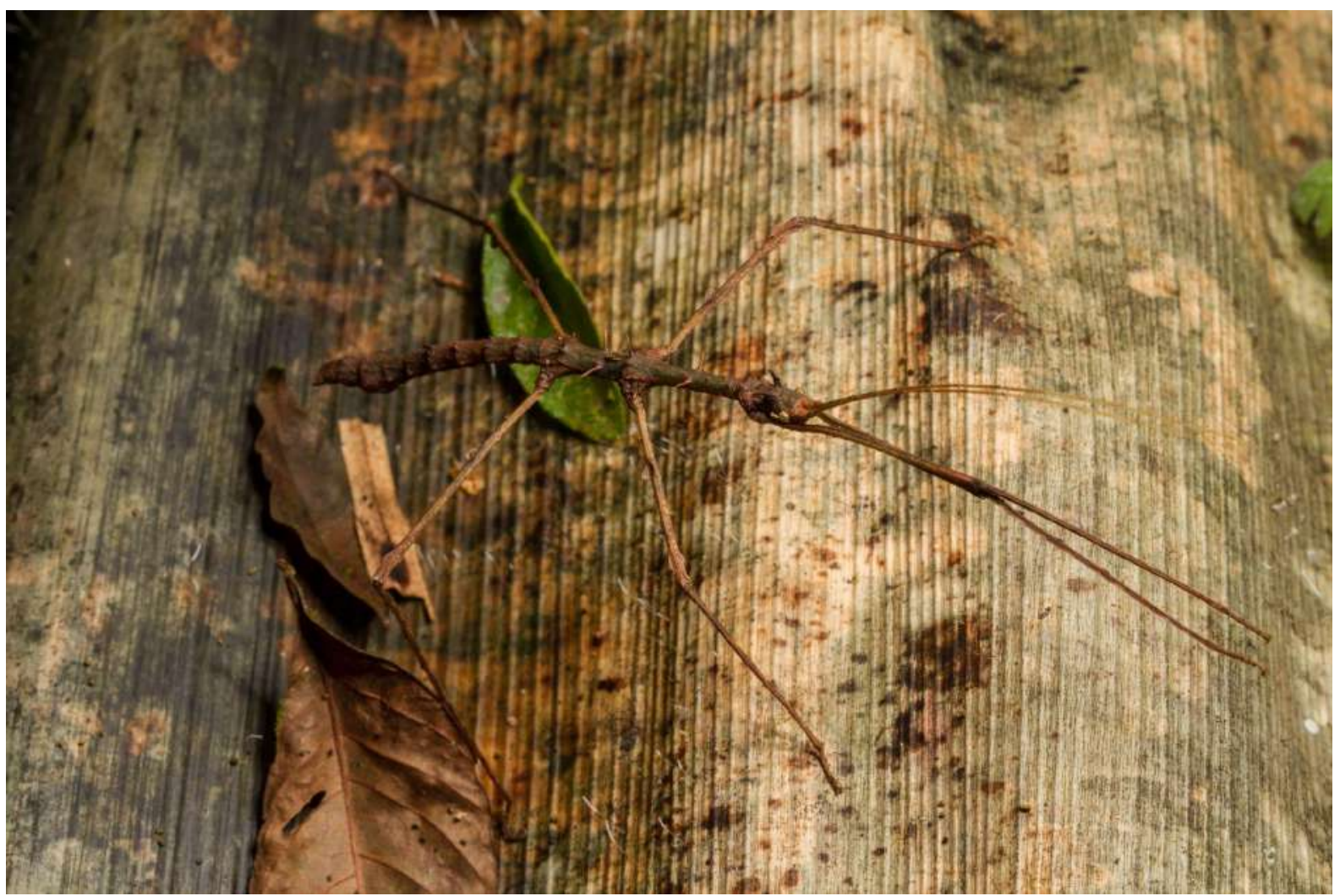

Figura 38: Macho adulto de Ceroys (Miroceroys) heymonsi in situ. Foto realizada por Pedro Alvaro Barbosa Aguiar Neves no Parque Estadual de Intervales. Imagem fora de escala. 


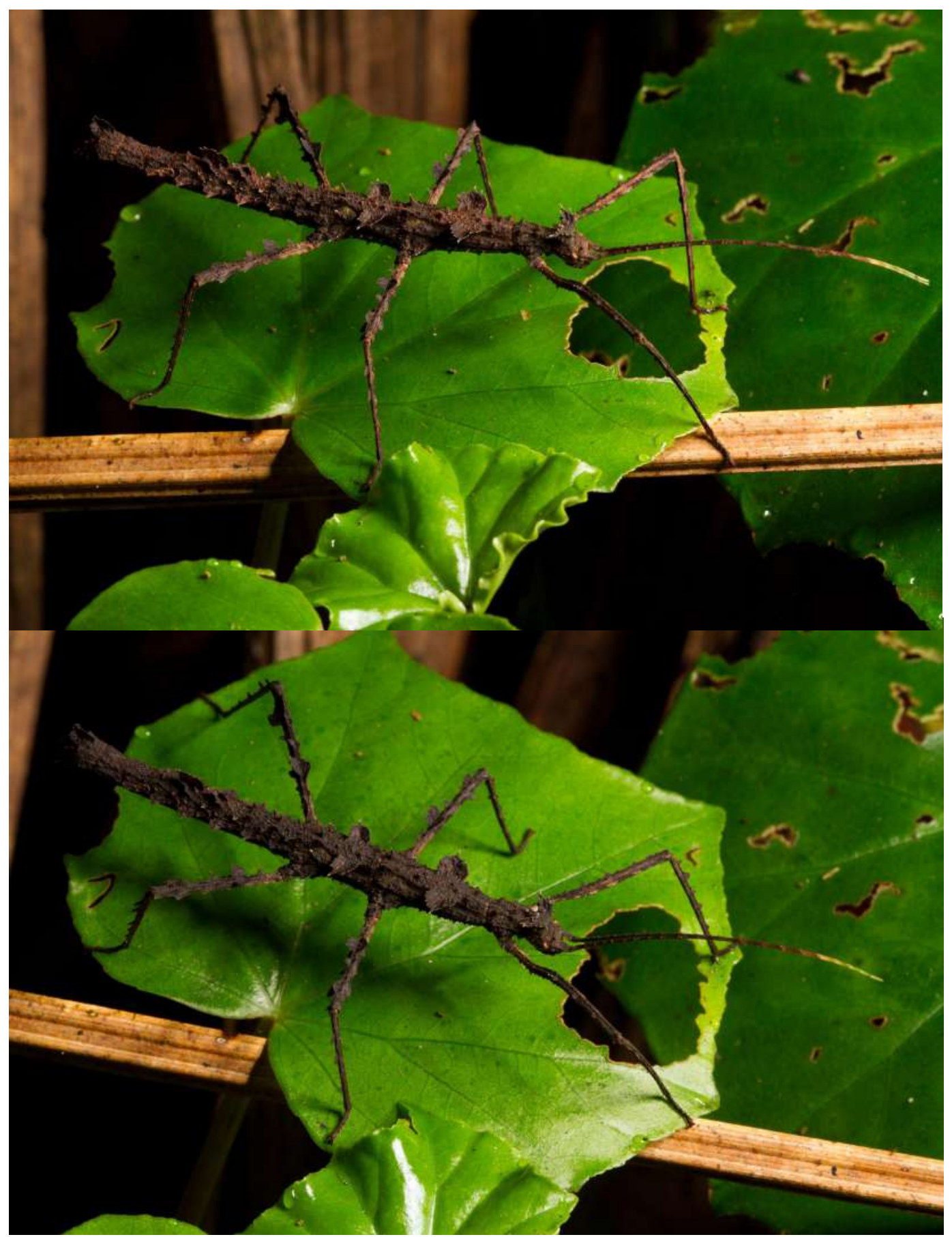

Figura 39: Fêmea adulta de Ceroys (Miroceroys) heymonsi in situ. A imagem mostra o mesmo indivíduo fotografada em um intervalo de de três horas depois. Mudanças na quantidade de luminosidade no ambiente resultaram na mudança da pigmentação corporal de forma a melhor se camuflar com o ambiente, como visto em Ceroys (Ceroys) cristatus. Foto realizada por Pedro Alvaro Barbosa Aguiar Neves no Parque Estadual de Intervales. Imagem fora de escala. 

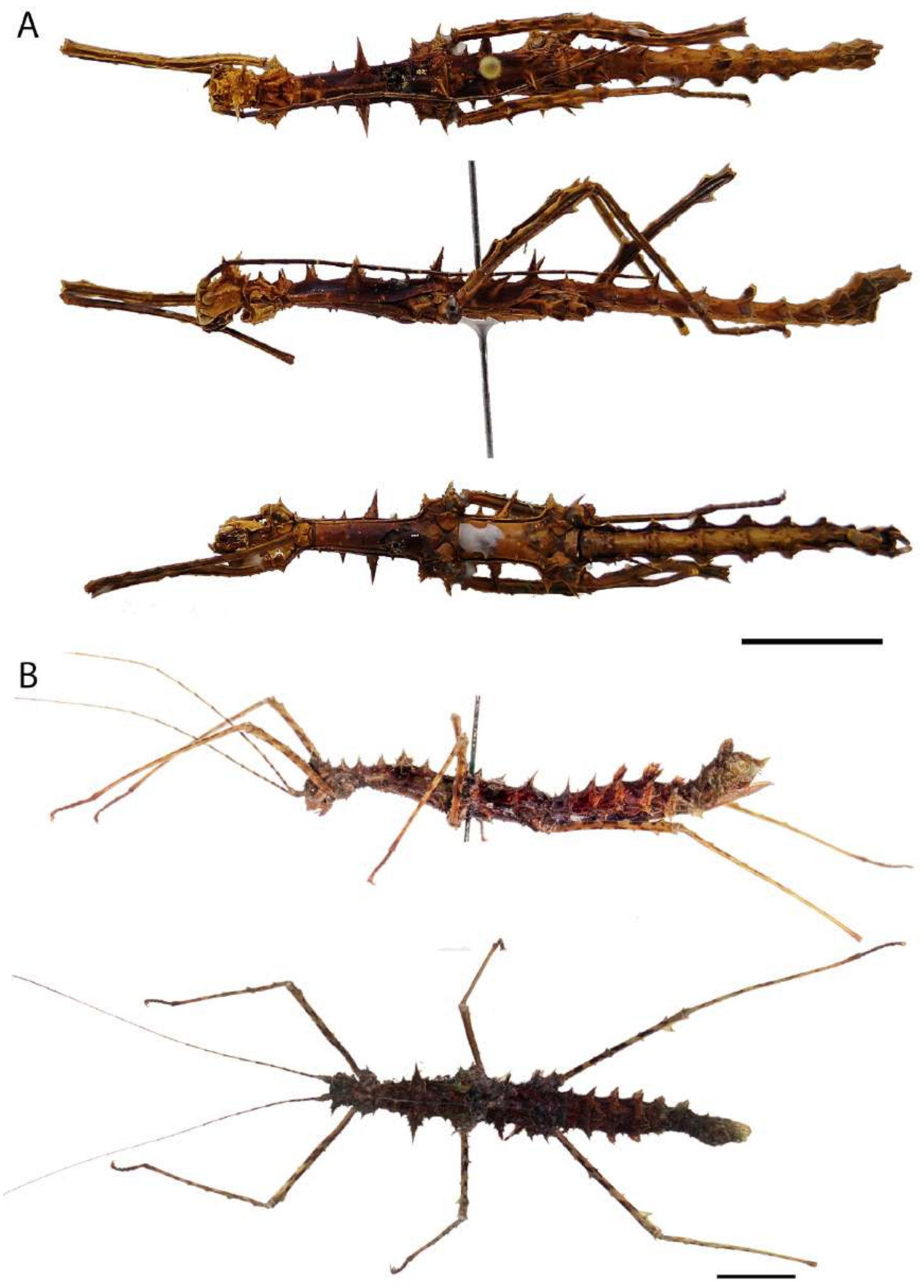

Figura 40: A. Holótipo de Ceroys (Miroceroys) redtenbacheri, sinônimo de Ceroys (Miroceroys) saevissimus, em vista dorsal, lateral e ventral. B. Holótipo de Ceroys (Miroceroys) saevissimus em vista lateral e dorsal. Barra de escala: $10 \mathrm{~mm}$. 

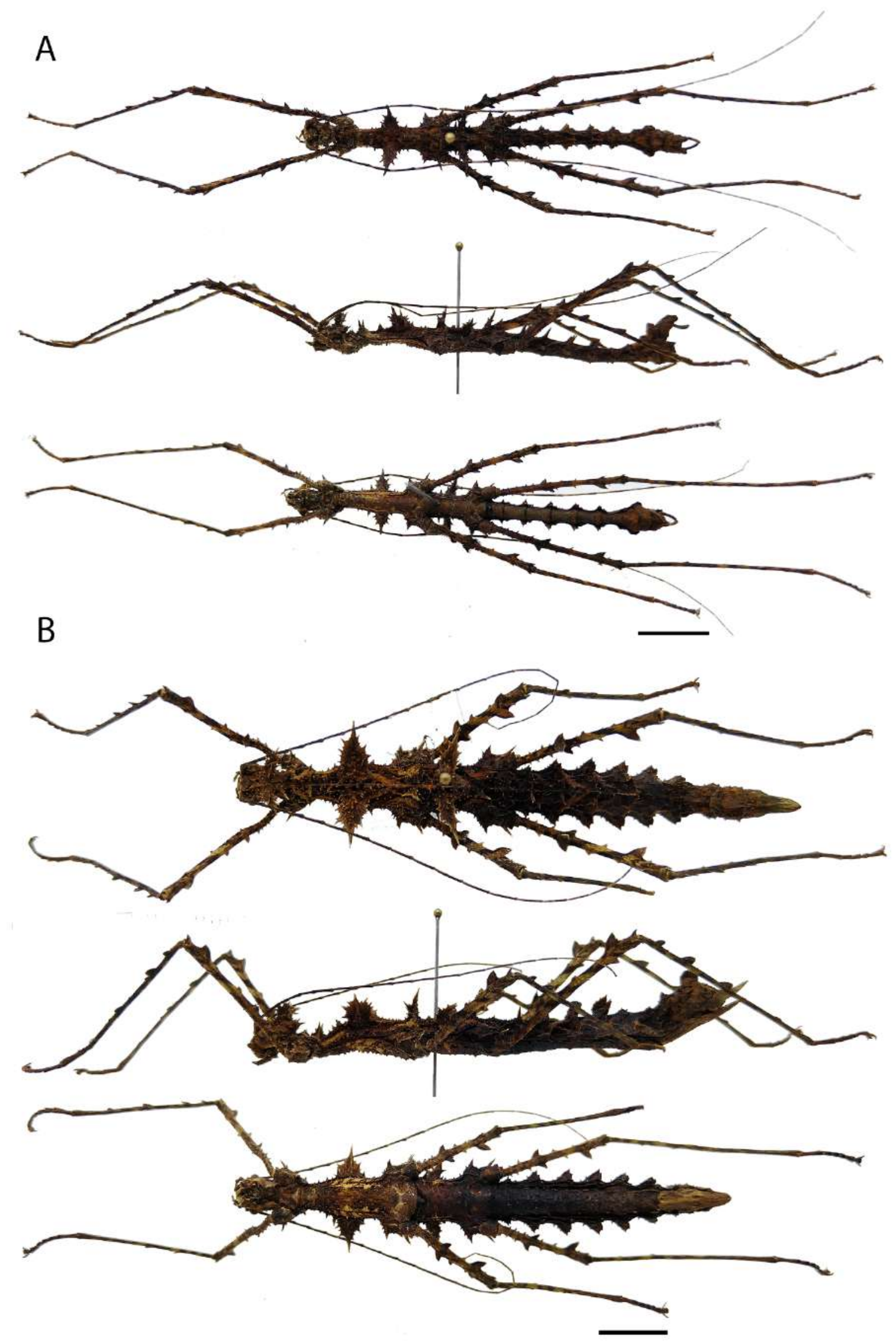

Figura 41: Macho e fêmea adultos de Ceroys (Miroceroys) saevissimus. A. Macho adulto em vista dorsal, lateral e ventral B. Fêmea adulta em vista dorsal, lateral e ventral. Barra de escala: $10 \mathrm{~mm}$. 


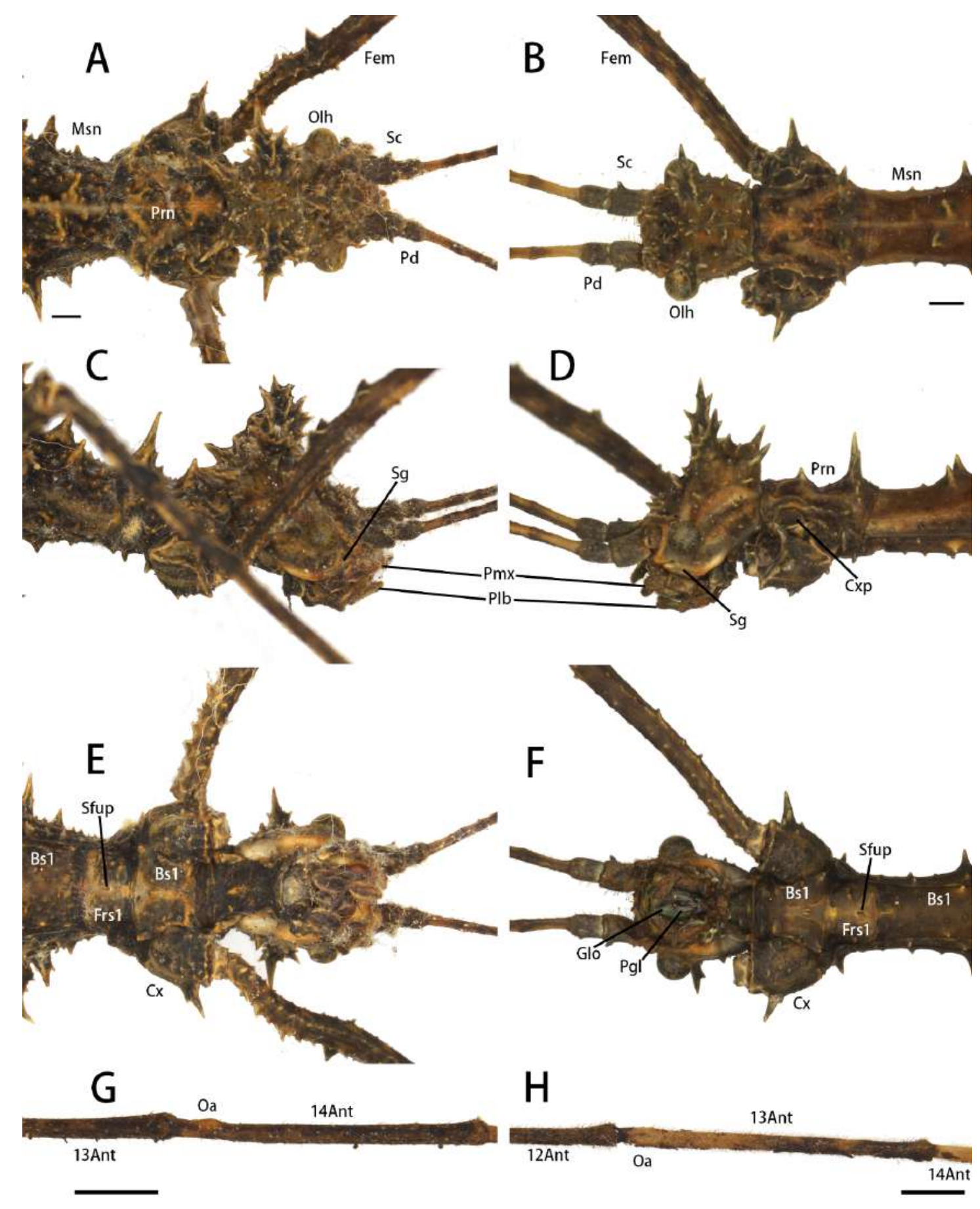

Figura 42: A-F. Detalhe da cabeça de Ceroys (Miroceroys) saevissimus. A, C, E. Fêmea adulta: A. Vista dorsal; C. Vista lateral; E. Vista ventral, G, H. Detalhe das antenas mostrando o órgão antenal do fêmea $(\mathbf{G})$ e macho $(\mathbf{H})$.. B, D, E. Macho adulto: B. Vista dorsal; D. Vista lateral; F. Vista ventral. Abreviações e acrônimos: Ant, antenômero; Bs1-Bs2, basisterno pro- e mesotorácico; Cx, coxa; Cxp, coxopleurito; Olh, olho; Fem, fêmur; Frs1, furcasternito protorácico; Gl, glossa; Msn, mesonoto; Pd, pedicelo; Pgl, paraglossa; Plb, Palpo labial; Pmx, palpo maxilar; Prn, pronoto; Sc, escapo; Sg, subgena; Sfup, sulco furcasternal; Oa, órgão antenal. Barra de escala: $1 \mathrm{~mm}$ 


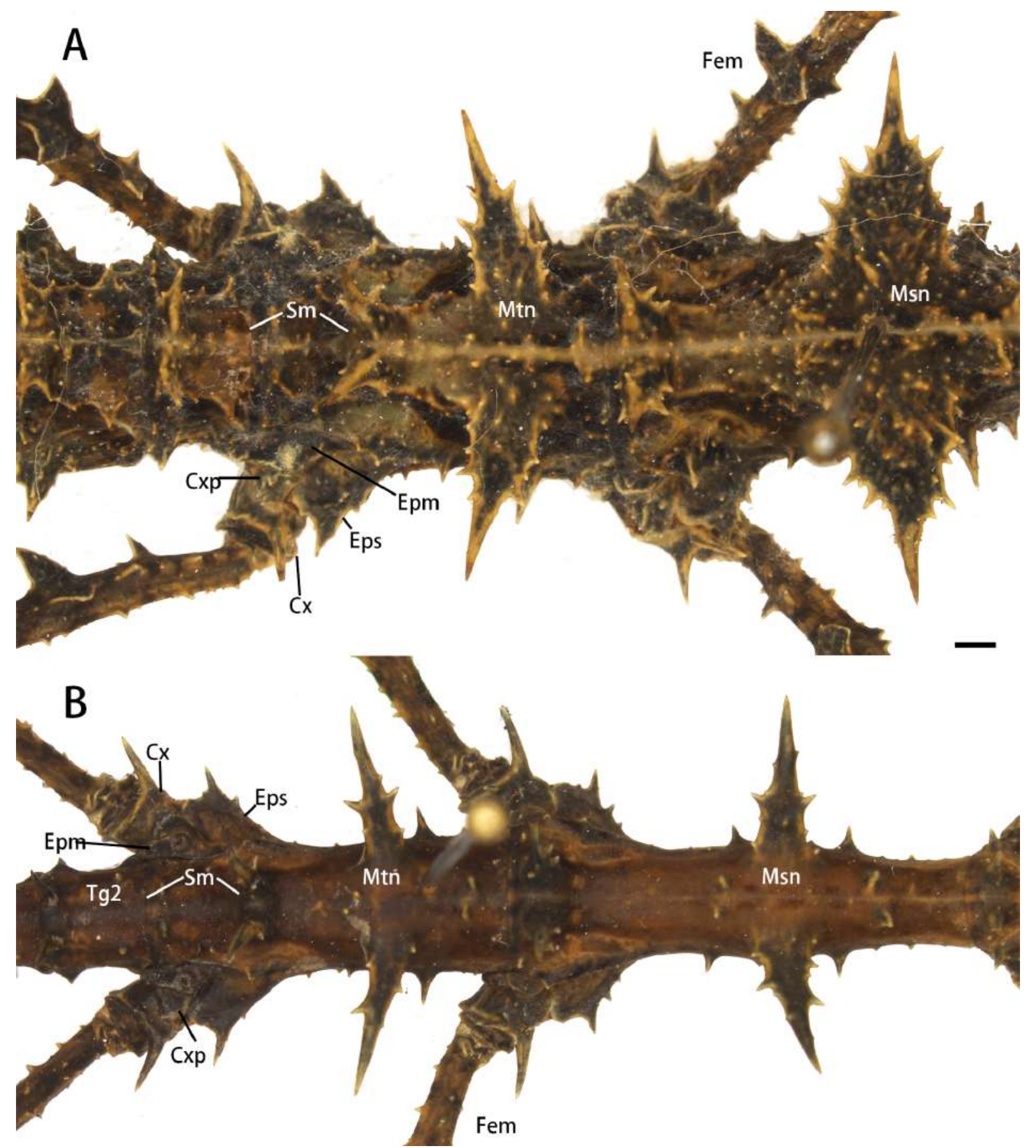

Figura 43: A-B. Morfologia do metatórax de Ceroys (Miroceroys) saevissimus em vista dorsal. A. Fêmea B. Macho. Abreviações e acrônimos: Cx, coxa; Cxp, coxopleurito; Epm, epímeron; Eps, episterno; Sm, segmento mediano; Msn, mesonoto; Mtn, metanoto; Tg, tergito; Fem, fêmur. Barra de escala: $1 \mathrm{~mm}$. 


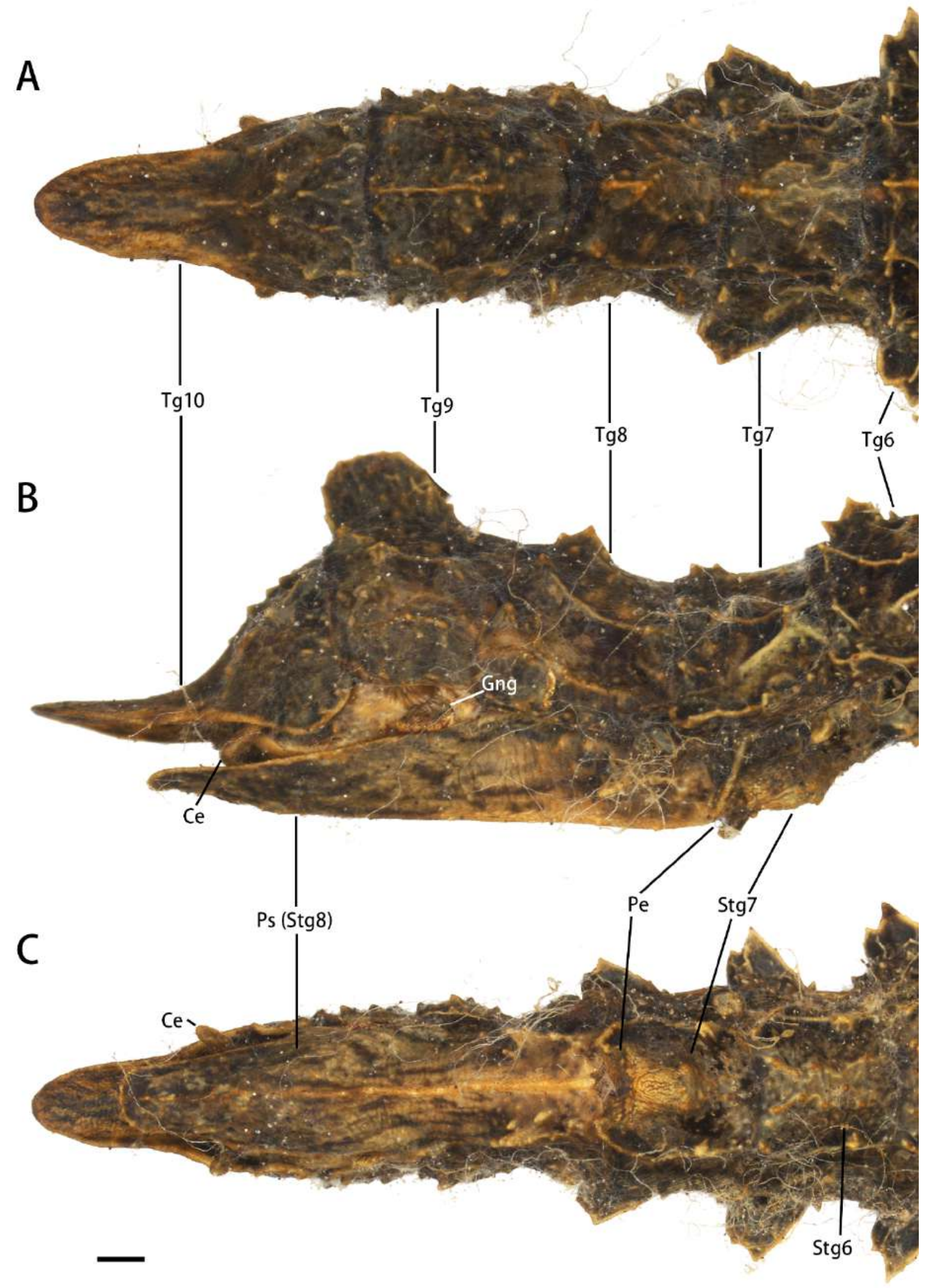

Figura 44:A-C. Morfologia do abdômen e terminália da fềmea de Ceroys (Miroceroys) saevissimus. A. Vista dorsal. B. Vista lateral; C. Vista ventral; Abreviações e acrônimos: Ce, cercos; Gng, gonângulo; Pe, órgão pré-opercular; Ps, Placa subgenital; St, esternito; Tg, tergito. Barra de escala: $1 \mathrm{~mm}$. 


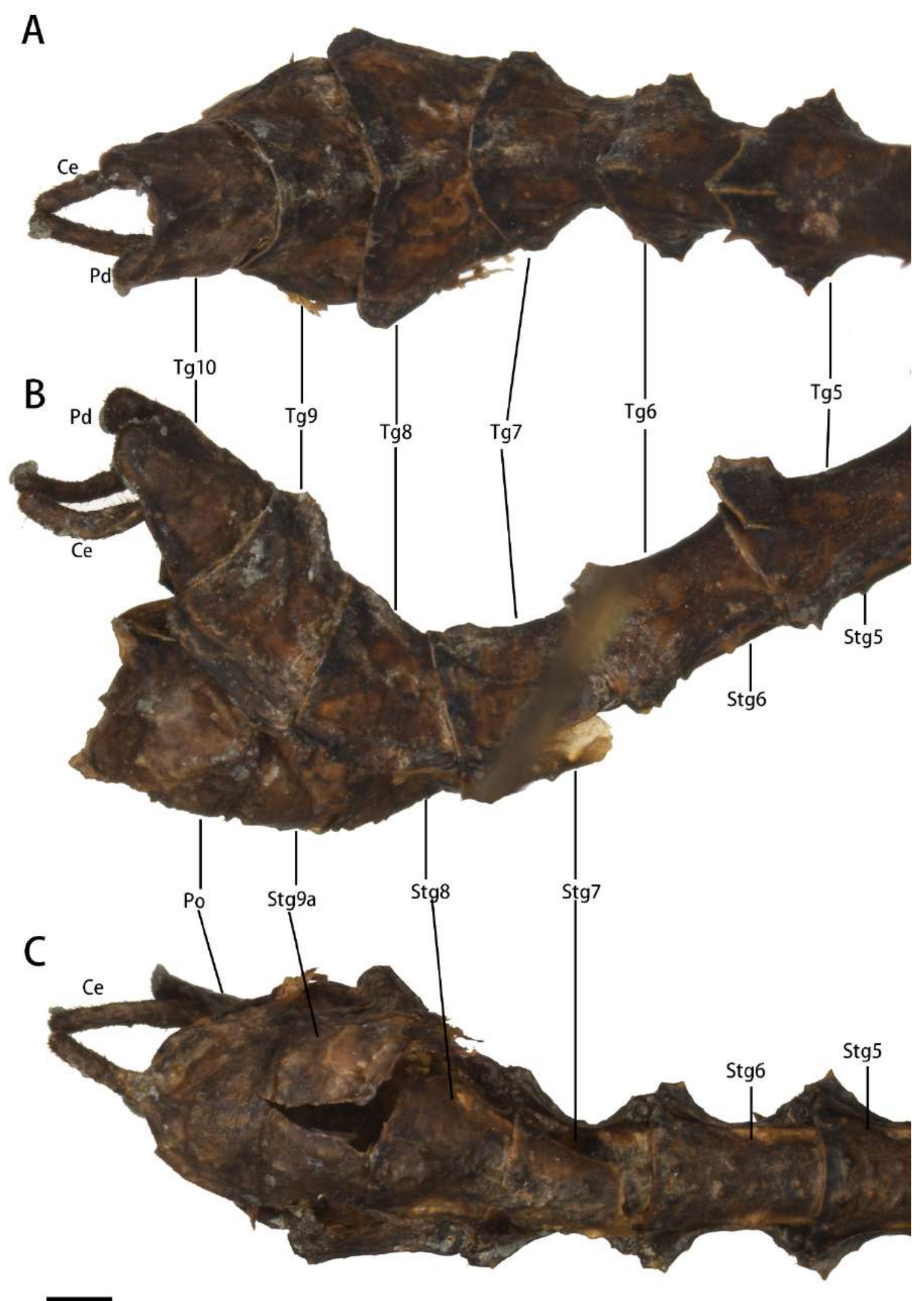

Figura 45:A-C. Morfologia do abdômen e terminália do macho de Ceroys (Miroceroys) saevissimus: A. Vista dorsal. B. Vista posterior; C. Vista ventral. Abreviações e acrônimos: Ce, cercos; Po, poculum; St, esternitos; St9a, porção anterior do esternito 9; Tg, tergito; Pd, placa dentada; Vo, vômer; Orf, Órgão fálico. Barra de escala: $\mathbf{A}-\mathbf{C}=1 \mathrm{~mm}$. 
A
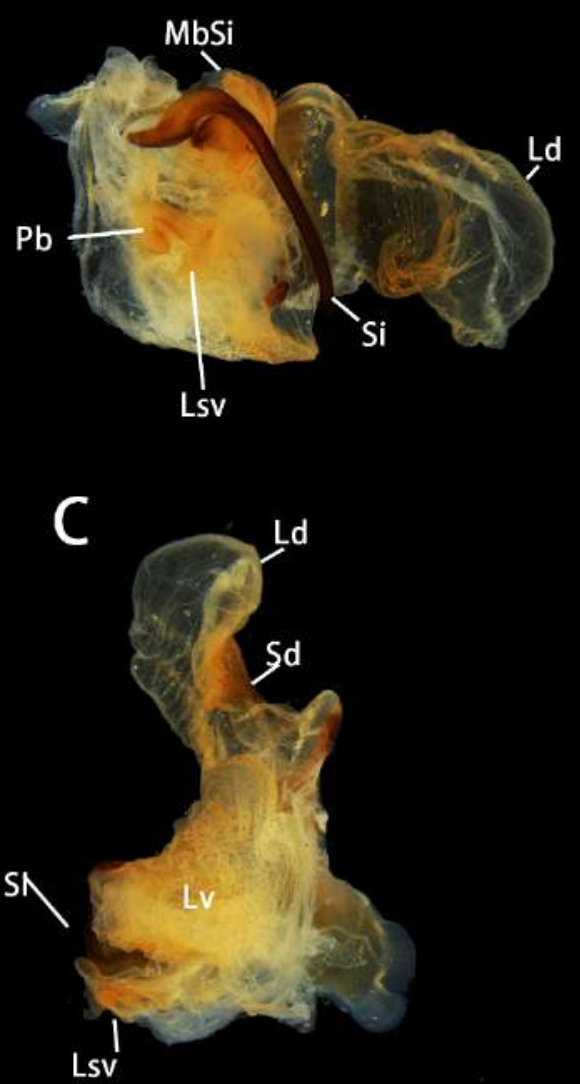

\section{B}

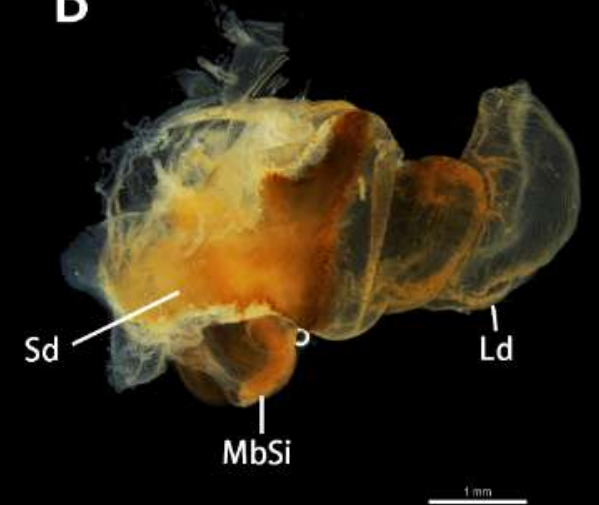

D

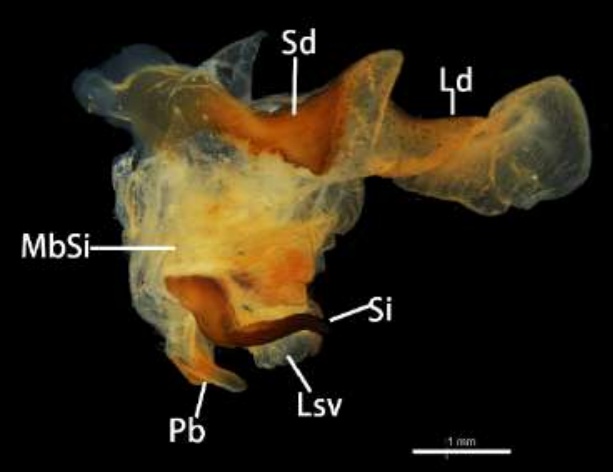

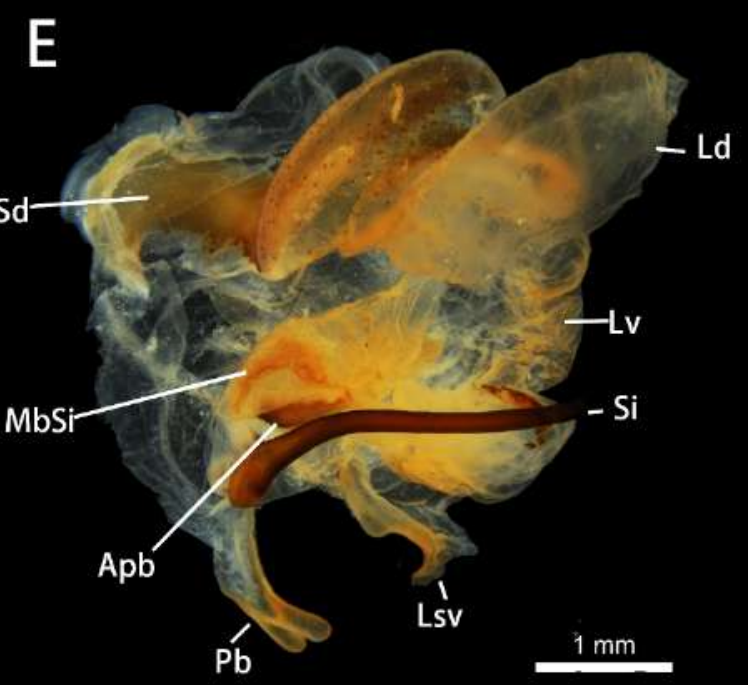

Figura 46: A-E. Morfologia da genitália masculina de Ceroys (Miroceroys) saevissimus: A. Vista dorsal. B. Vista ventral; C. Vista lateral esquerda; D. Vista lateral direita; E. Vista caudal; Abreviações e acrônimos: Sd, esclerito dorsal; Si, esclerito interno; Ld, lóbulo dorsal; Apb, Apódema basal; Mbsi, Membrana do esclerito interno; Pb, projeção bífida; Lsv, Lóbulo sinuoso ventral; LV, Lóbulo ventral. Barra de escala: $1 \mathrm{~mm}$. 


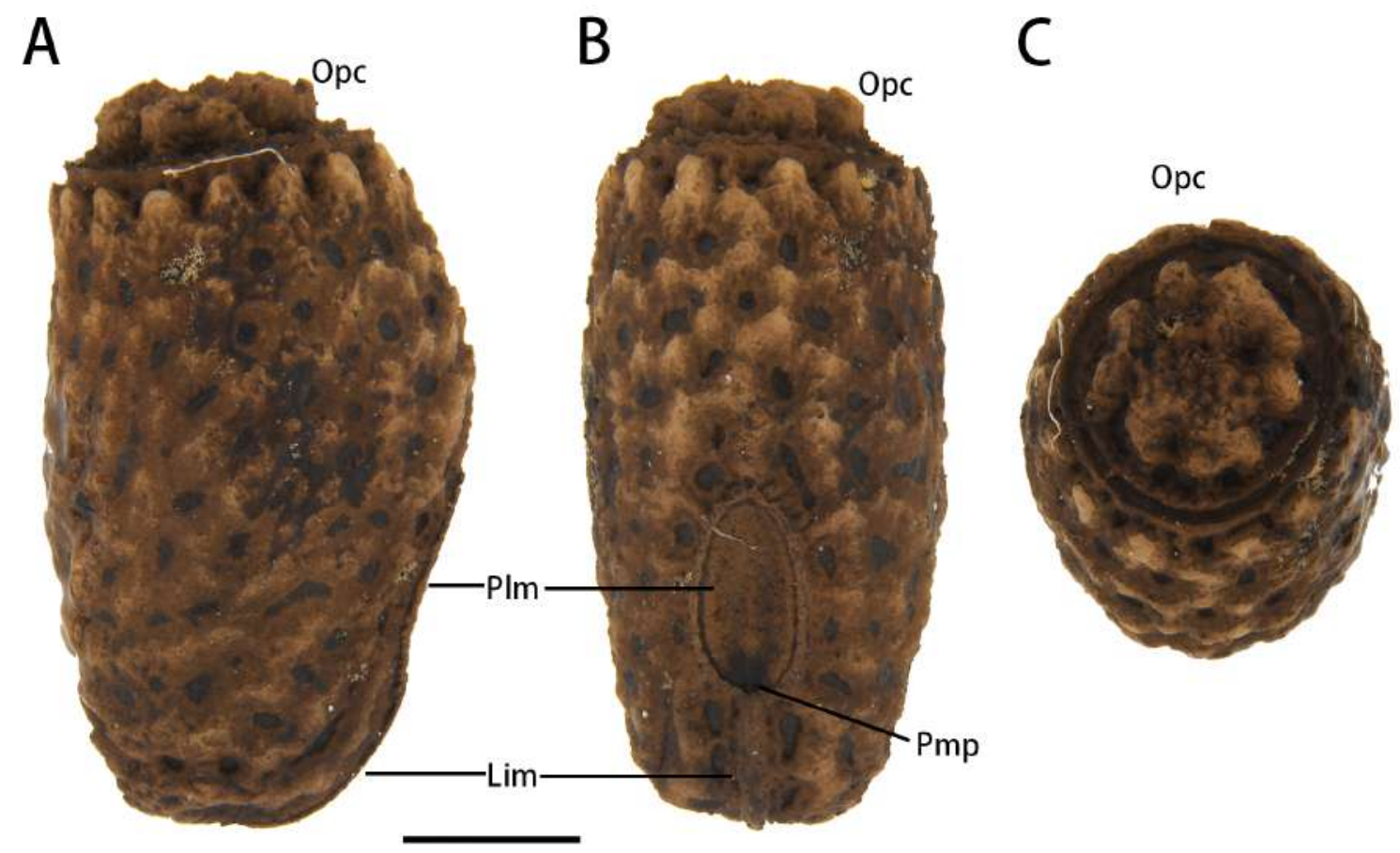

Figura 47: A-C. Ovo de Ceroys (Miroceroys) saevissimus: A. Vista lateral. B. Vista dorsal. C. Vista anterior. Abreviações e acrônimos: Pmp, poro micropilar; PIm, placa micropilar; Lim, linha mediana; Opc, opérculo. Barra de escala: $1 \mathrm{~mm}$.

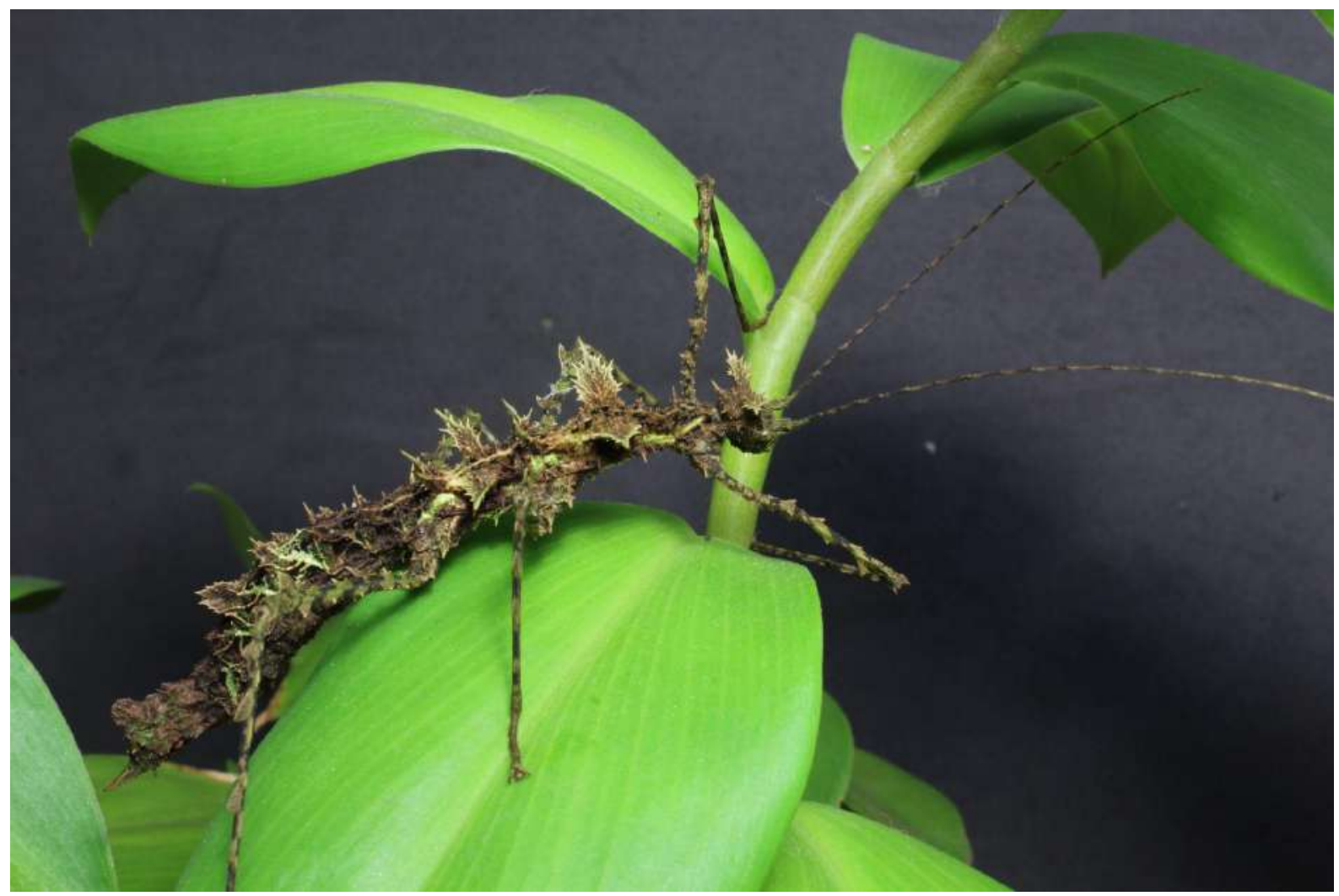

Figura 48: Fêmea adulta de Ceroys (Miroceroys) saevissimus ex situ. Foto realizada por Pedro Ivo Chiquetto-Machado. Imagem fora de escala. 


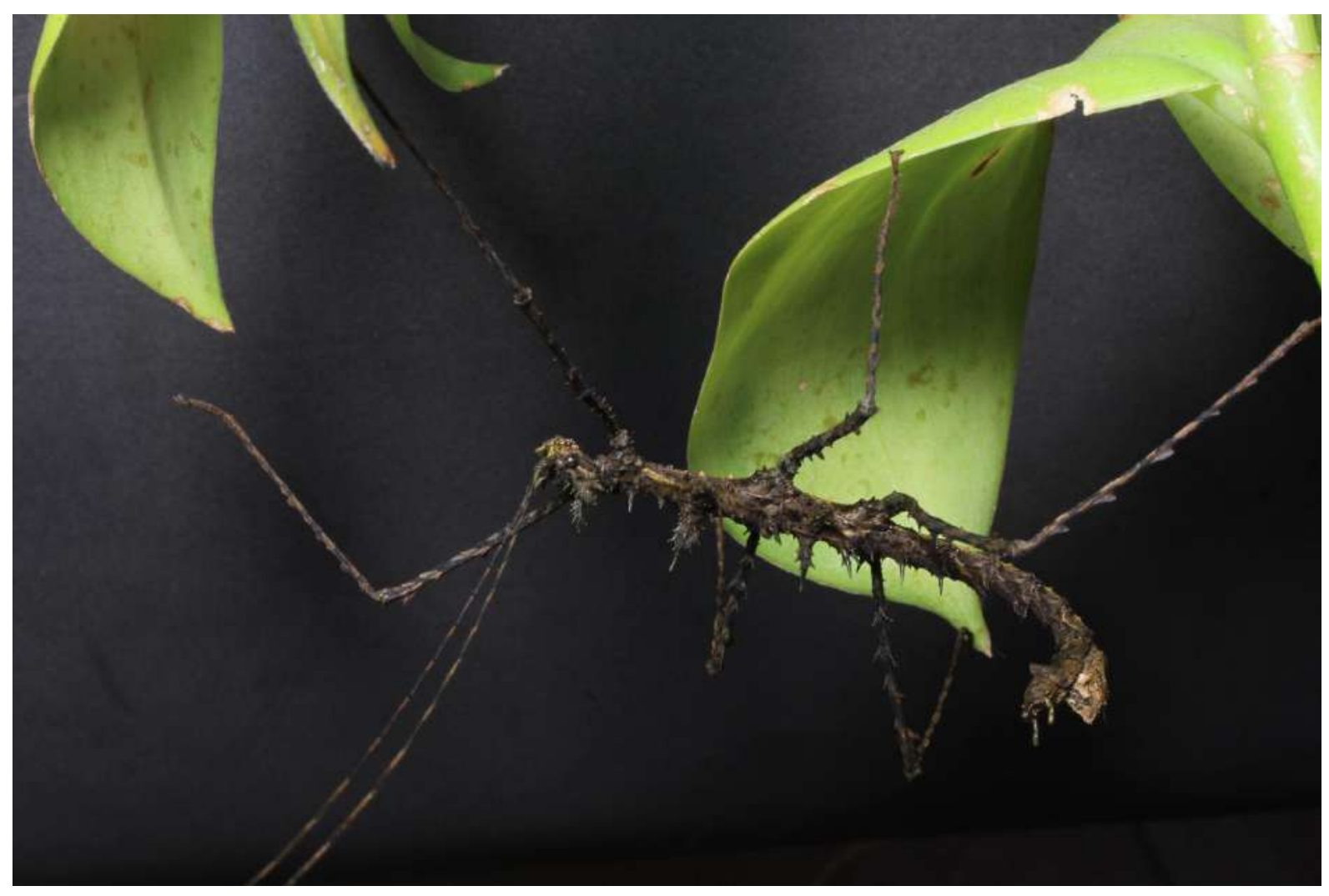

Figura 49: Macho adulto de Ceroys (Miroceroys) saevissimus ex situ. Foto realizada por Pedro Ivo Chiquetto-Machado. Imagem fora de escala. 


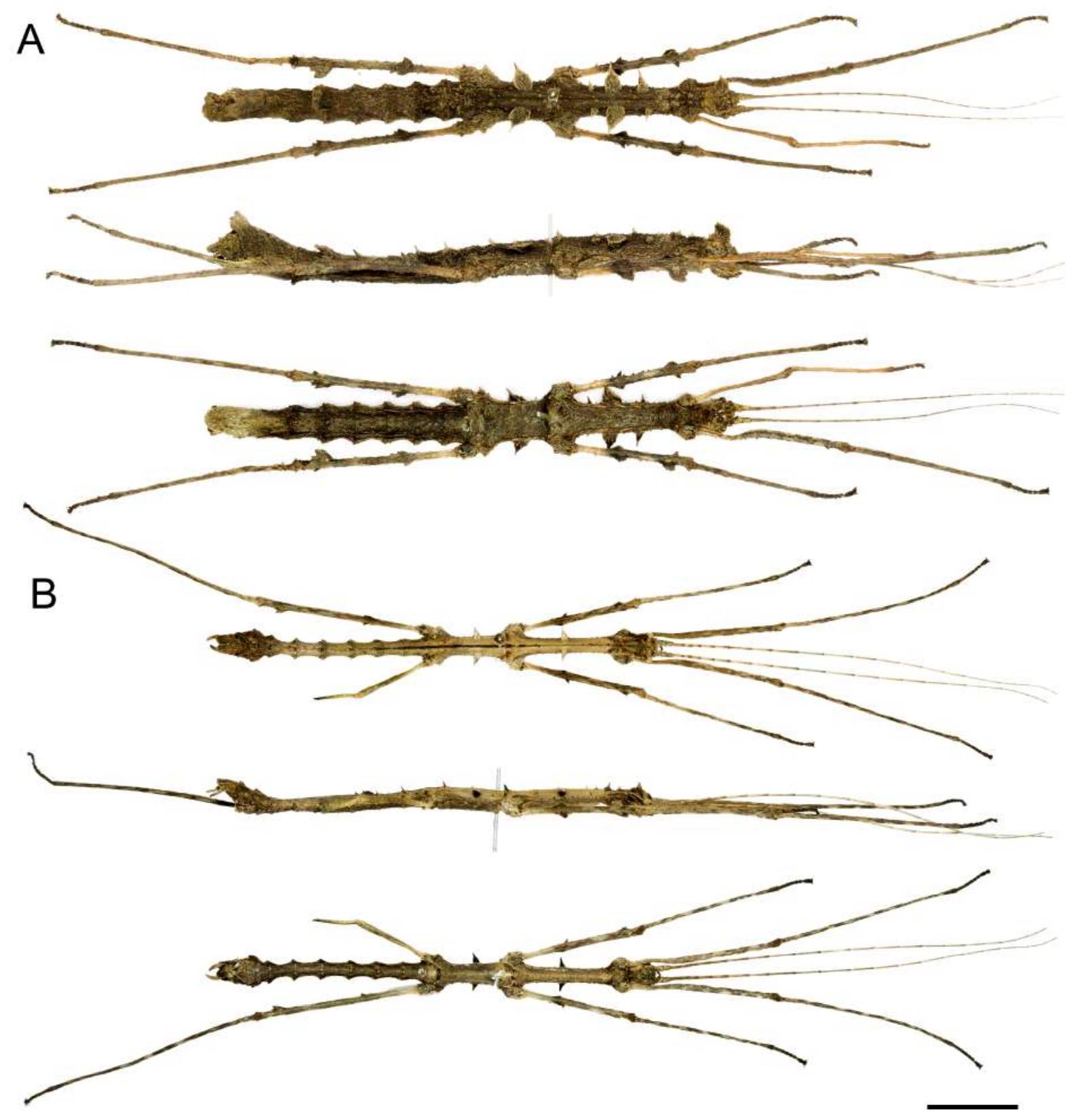

Figura 50: A-B. Fêmea e macho adulto de Ceroys (Miroceroys) sp. nov., de Extrema, Minas Gerais, Brasil. A. Fêmea adulta em vista dorsal, lateral e ventral. B. Macho adulto em vista dorsal, lateral e ventral. Barra de escala: $10 \mathrm{~mm}$. 


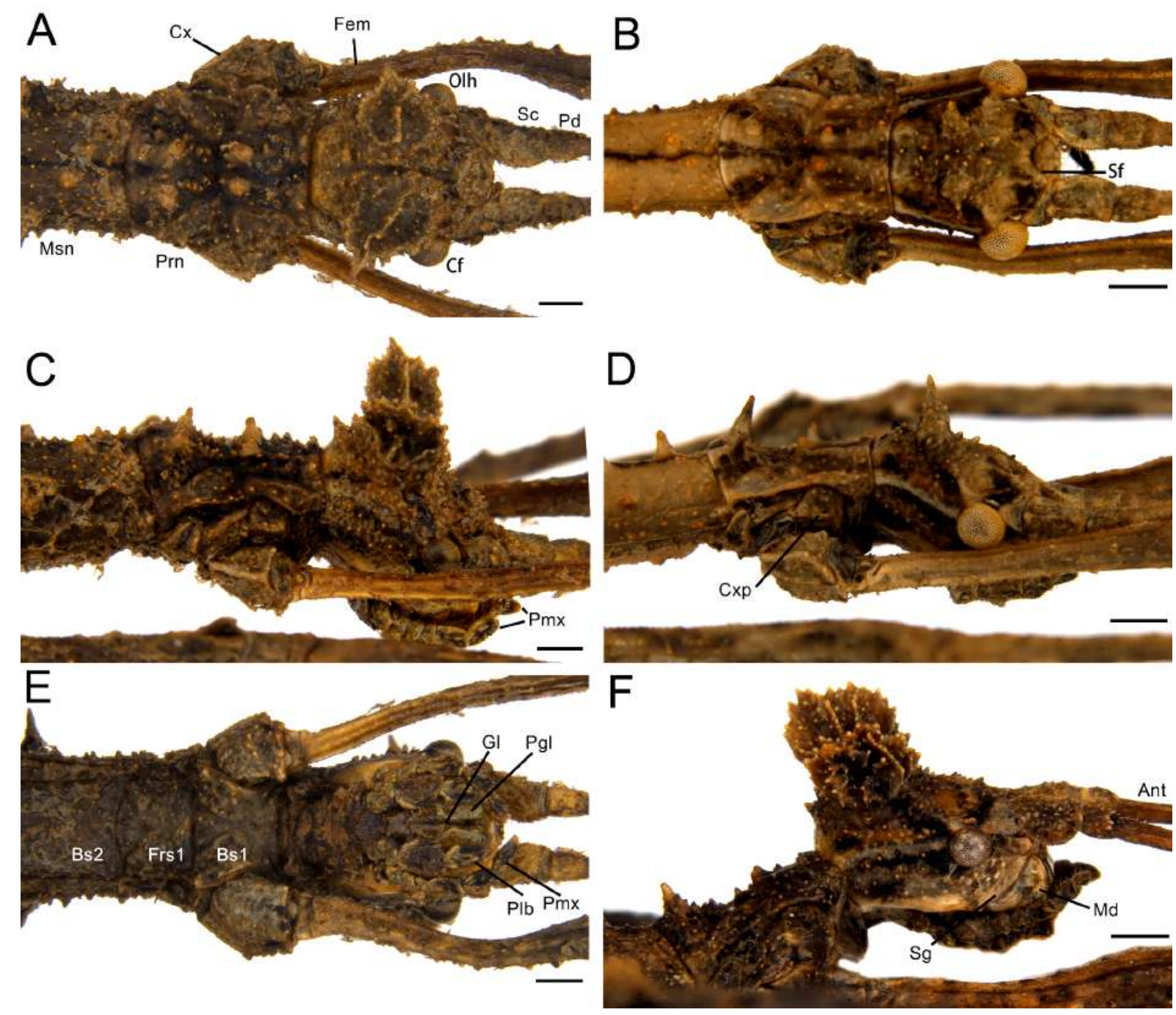

Figura 51: A-B. Detalhe da cabeça de Ceroys (Miroceroys) sp. nov. A, C, E. Fêmea adulta: A. Vista dorsal; C. Vista lateral; E. Vista ventral. B, D. Macho adulto: B. Vista dorsal; D. Vista lateral. F. Fêmea juvenil, vista lateral. Abreviações e acrônimos: Ant, antenômero; Bs1-Bs2, basisterno pro- e mesotorácico; Cx, coxa; Cxp, coxopleurito; Olh, olho; Cf, Convexidade frontal; Fem, fêmur; Frs1, furcasternito protorácico; Sf, sutura frontal; Gl, glossa; Md, mandíbula; Msn, mesonoto; Pd, pedicelo; Pgl, paraglossa; Plb, Palpo labial; Pmx, palpo maxilar; Prn, pronoto; Sc, escapo; Sg, subgena. Barra de escala: $1 \mathrm{~mm}$. 


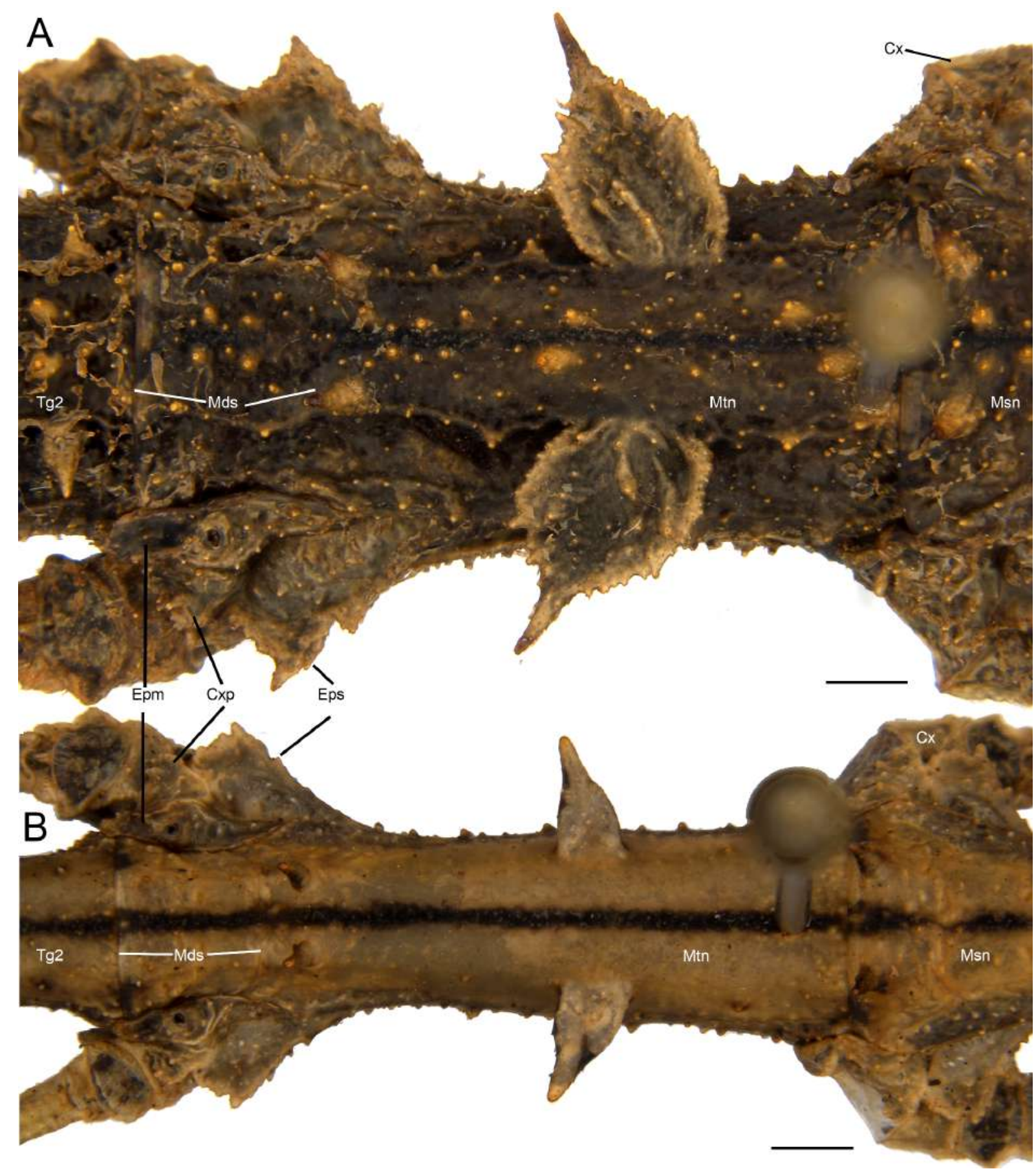

Figura 52: A-B. Morfologia do metatórax de Ceroys (Miroceroys) sp. nov. em vista dorsal. A. Fêmea B. Macho. Abreviações e acrônimos: Cx, coxa; Cxp, coxopleurito; Epm, epímeron; Eps, episterno; Sm, segmento mediano; Msn, mesonoto; Mtn, metanoto; Tg, tergito. Barra de escala: $1 \mathrm{~mm}$. 

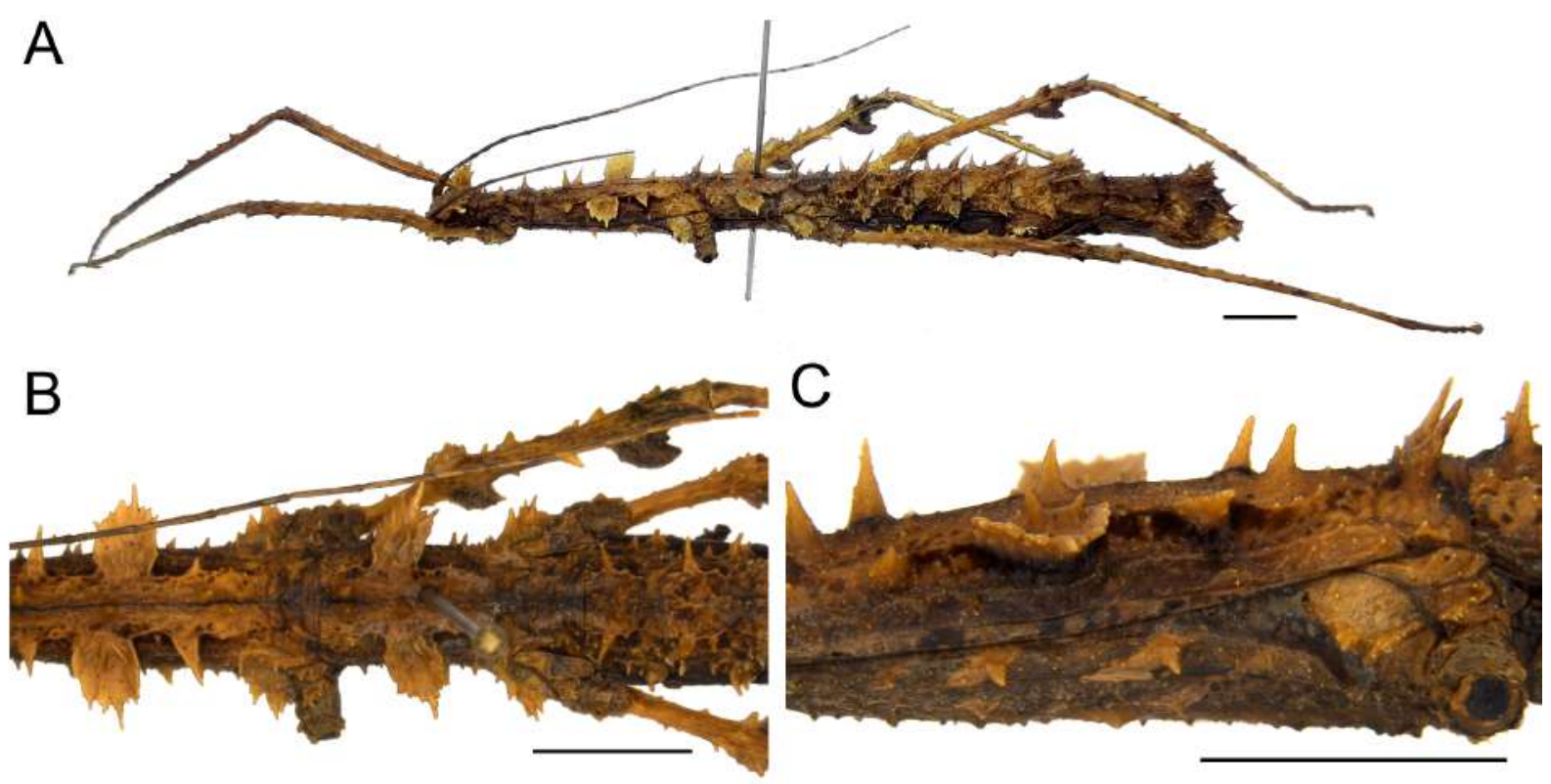

Figura 53: A-C. Variação do padrão de ornamentação em Ceroys (Miroceroys) sp. nov. coletada em Camanducaia, Minas Gerais, Brasil. A. Corpo inteiro do indivíduo. B. Detalhe do tórax em vista dorsal C. Detalhe do tórax em vista lateral. Barra de escala: $0.5 \mathrm{~mm}$. 


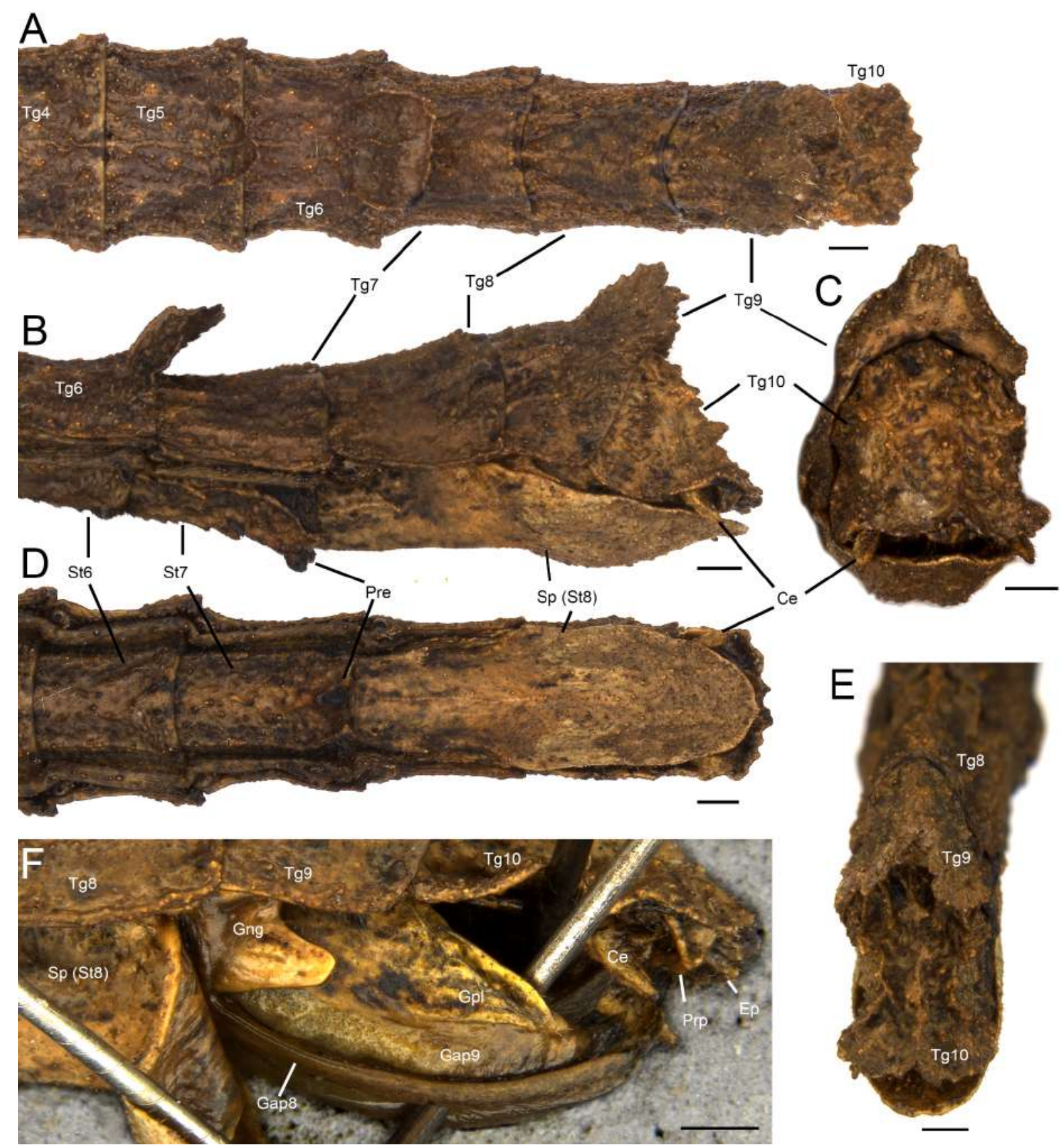

Figura 54:A-F. Morfologia do abdômen e terminália da fêmea de Ceroys (Miroceroys) sp. nov. A. Vista dorsal. B. Vista lateral; C. Vista posterior; D. Vista ventral; E. Vista posteroventral; F. Detalhe da terminália e estruturas do ovipositor em vista lateral, placa subgenital afastada por alfinetes. Abreviações e acrônimos: Ce, cercos; Ep, epiprocto; Gap8-Gap9, gonapófise 8 e 9; Gng, gonângulo; Gpl, gonoplaca; Pe, órgão pré-opercular; Ps, Placa subgenital; St, esternito; Tg, tergito. Barra de escala: $1 \mathrm{~mm}$. 

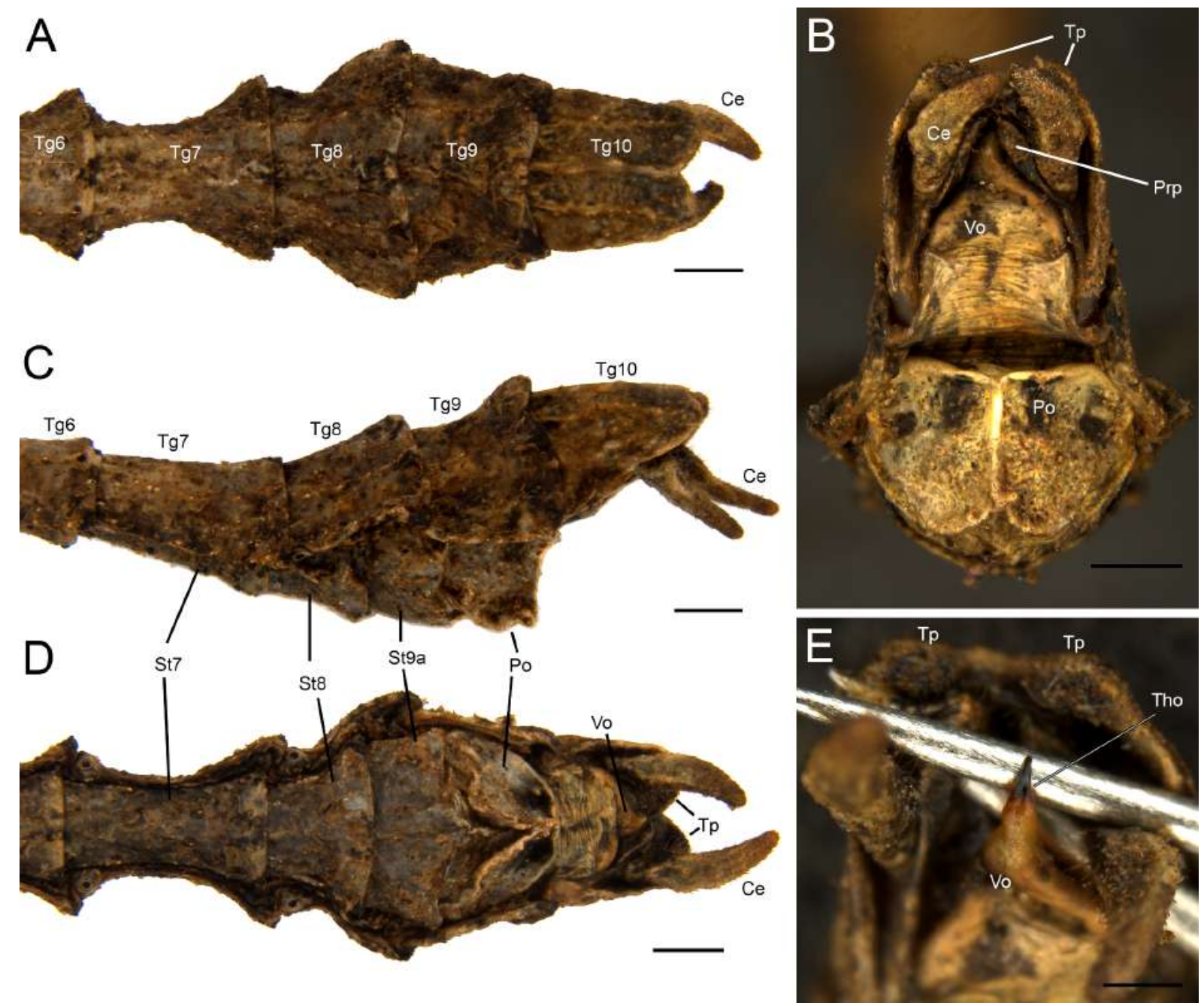

Figura 55:A-E. Morfologia do abdômen e terminália do macho de Ceroys (Miroceroys) sp. nov.: A. Vista dorsal. B. Vista posterior; C. Vista lateral; D. Vista ventral; E. Vista posterior, detalhe do ápice do vômer. Abreviações e acrônimos: Ce, cercos; Po, poculum; Prp, paraprocto; St, esternitos; St9a, porção anterior do esternito 9; Tg, tergito; Pd, placa dentada; Vo, vômer. Seta, porção apical do vômer; Barra de escala: $\mathbf{A}-\mathbf{D}=1 \mathrm{~mm} ; \mathbf{E}=0.5 \mathrm{~mm}$. 


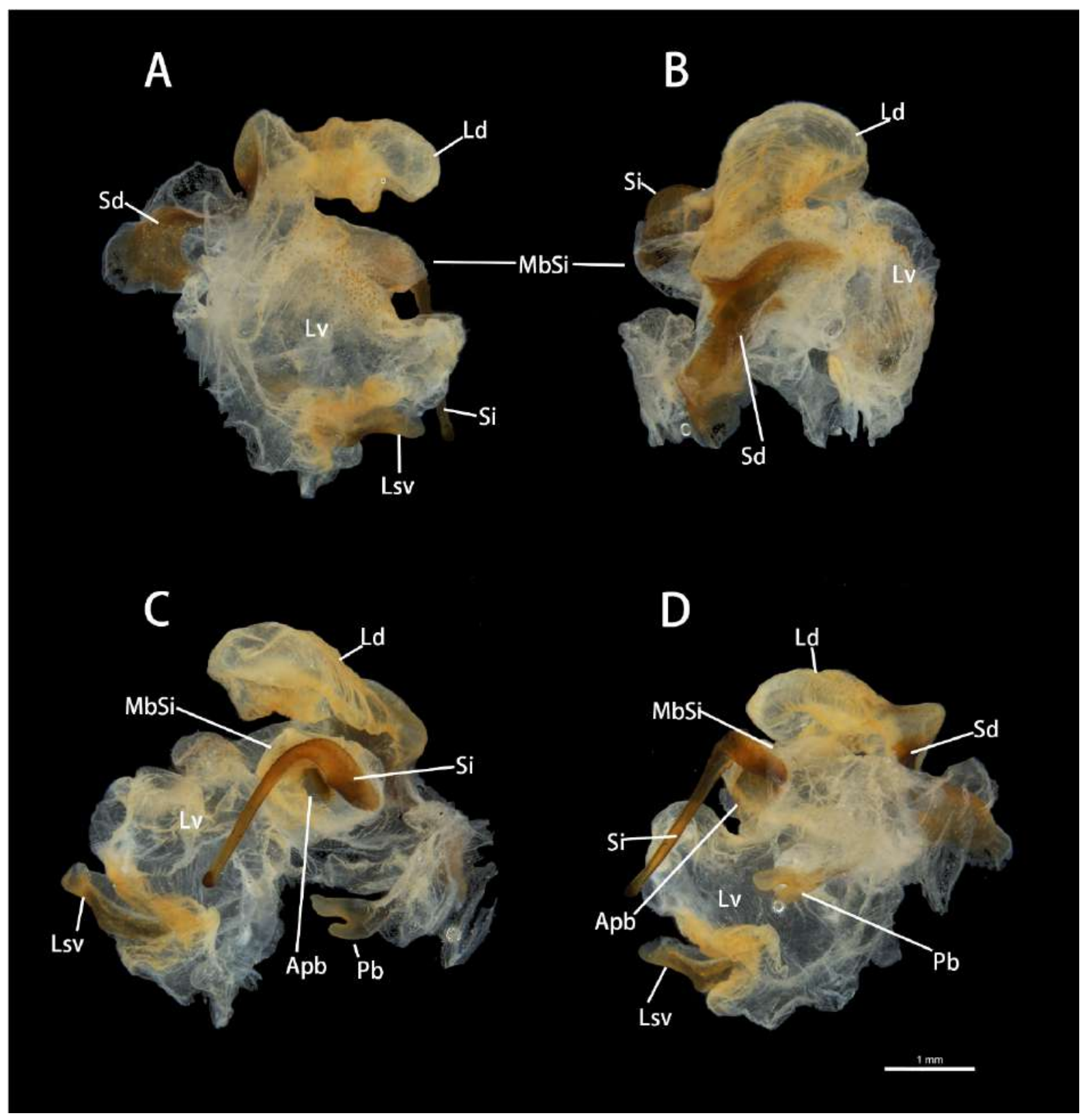

Figura 56: A-E. Morfologia da genitália masculina de Ceroys (Miroceroys) sp. nov.: A. Vista dorsal. B. Vista ventral; C. Vista lateral esquerda; D. Vista lateral direita.Abreviações e acrônimos: Sd, esclerito dorsal; Si, esclerito interno; Ld, lóbulo dorsal; Apb, Apódema basal; Mbsi, Membrana do esclerito interno; Pb, projeção bífida; Lsv, Lóbulo sinuoso ventral; LV, Lóbulo ventral. Barra de escala: $1 \mathrm{~mm}$. 

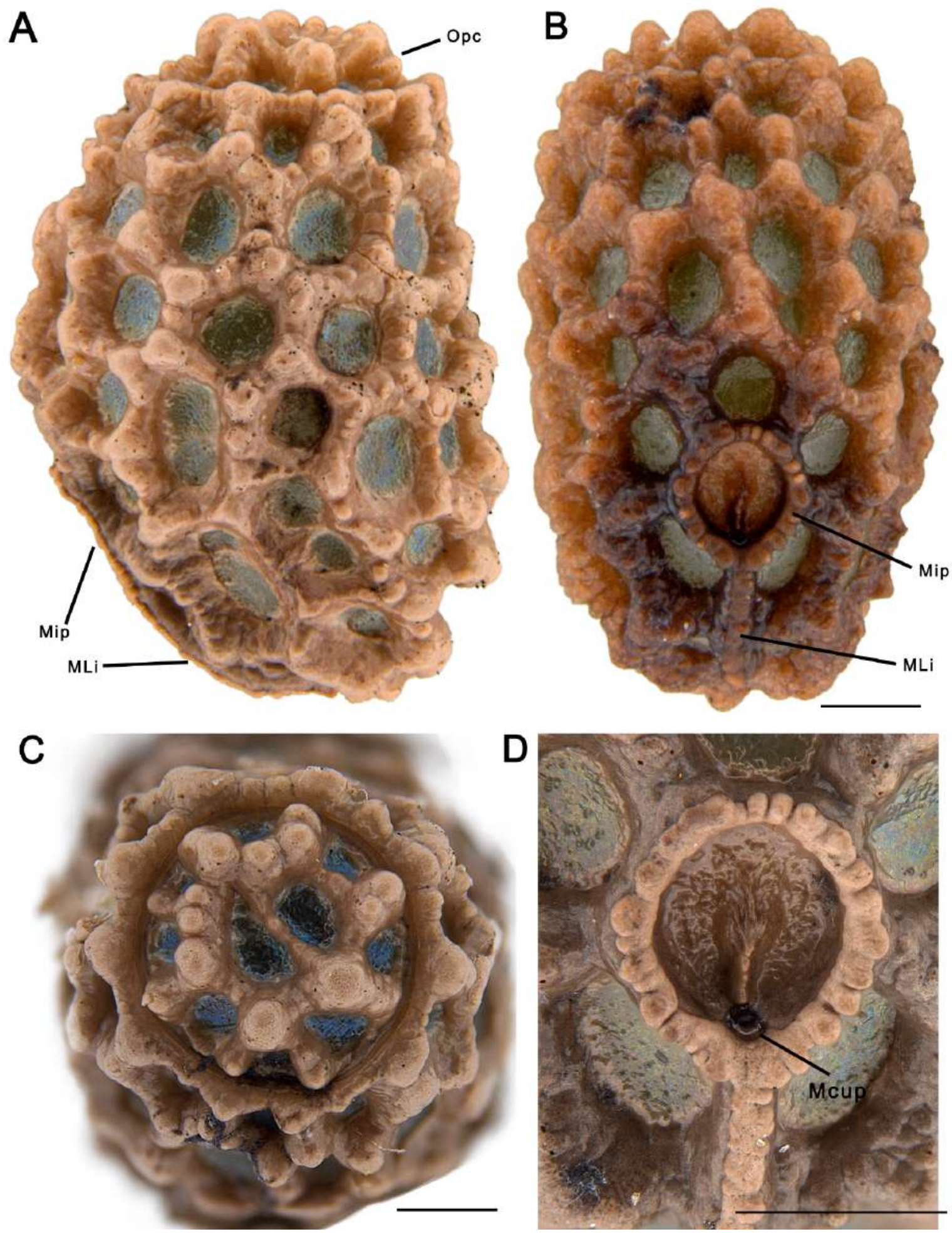

Figura 57: A-D. Ovo de Ceroys (Miroceroys) sp. nov. A. Vista lateral. B. Vista dorsal. C. Vista anterior. D. Detalhe da placa micropilar em vista dorsal. Abreviações e acrônimos: Pmp, poro micropilar; PIm, placa micropilar; Lim, linha mediana; Opc, opérculo. Barra de escala: $0.5 \mathrm{~mm}$. 

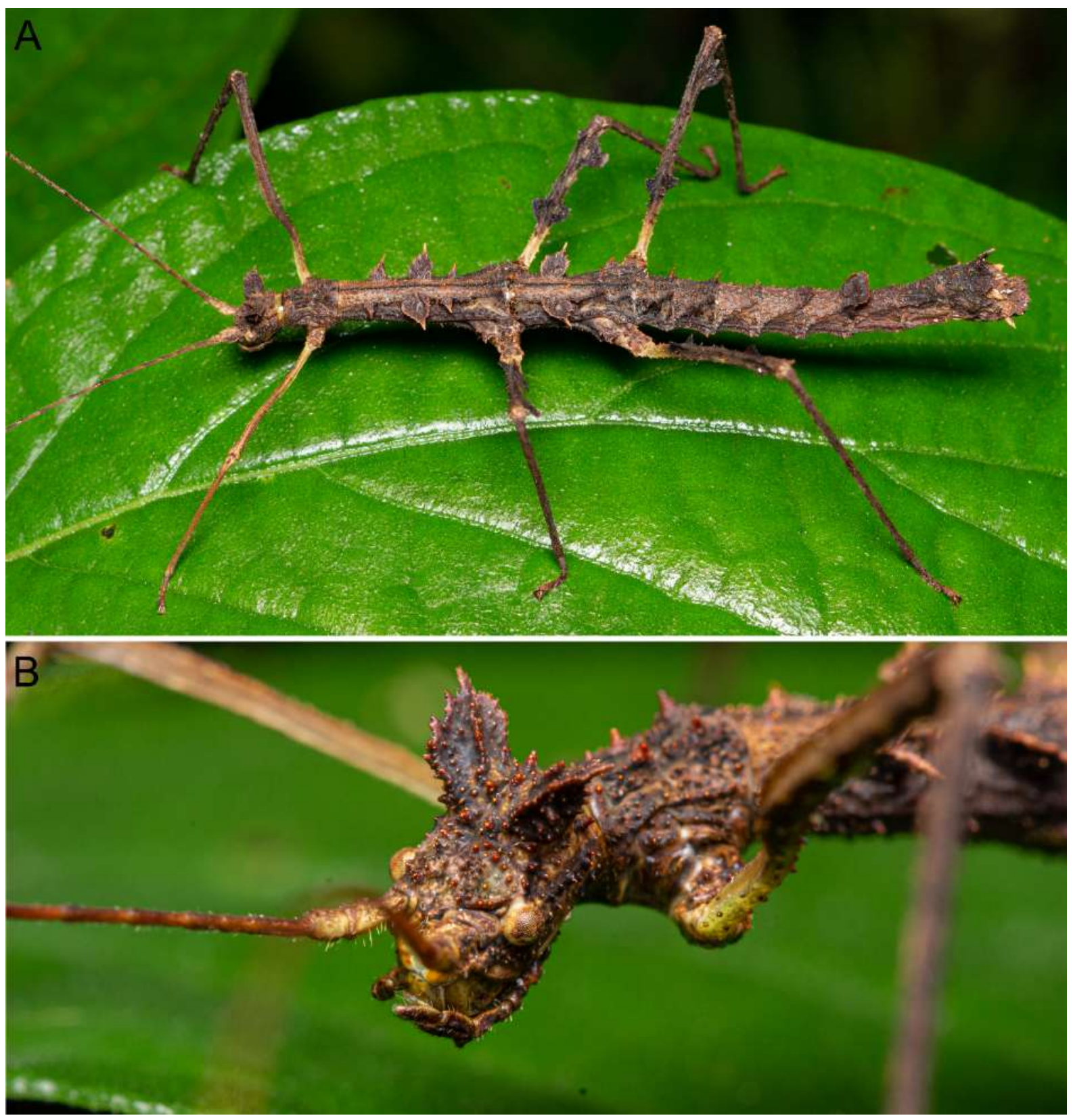

Figura 58: A-B. Habitus de uma fêmea adulta de Ceroys (Miroceroys) sp. nov., de Extrema, Minas Gerais, Brasil. A. Corpo inteiro. B. Detalhe da cabeça. Imagens fora de escala. 

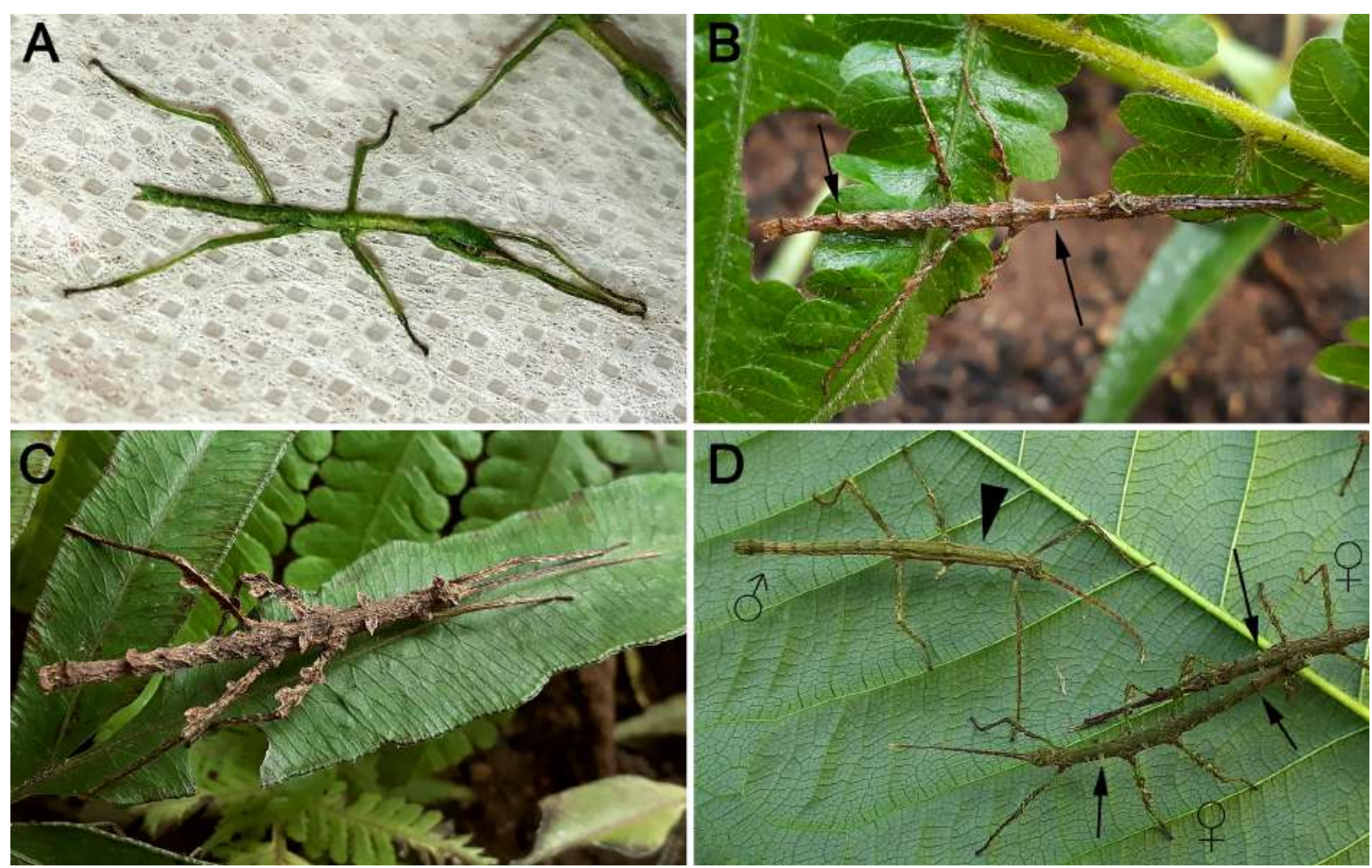

Figura 59: A-D. Habitus de ninfas vivas de Ceroys (Miroceroys) sp. nov., de Extrema, Minas Gerais, Brasil. A. Ninfa de primeiro instar, recém eclodida. B. Fêmea de terceiro instar repousando na vegetação do terrário. C. Fêmea de quarto ou quinto instar descansado sobre a vegetação do terrário. D. Três ninfas de terceiro instar: macho (à esquerda) e fềmeas (à direita). Setas indicam os lóbulos no tórax e abdômen da fêmea, ausentes no corpo do jovem macho (indicado pelo triângulo). Imagens fora de escala. 
Tabela 3: Intervalo de medidas do material de Ceroys (Ceroys) perfoliatus. As medidas correspondem aos valores máximos e mínimos dos espécimes analisados, em milímetros.

\begin{tabular}{|c|c|c|}
\hline & $\delta^{\lambda}(n=27)$ & $q(n=23)$ \\
\hline Corpo & $54,95-57,8$ & $73,9-74,26$ \\
\hline Antena & $3,24-3,46$ & $56,2-57,3$ \\
\hline Cabeça & $51,4-54,3$ & $5,29-5,65$ \\
\hline Pronoto & $3,19-3,35$ & $4,44-4,88$ \\
\hline Mesonoto & $14,24-15,1$ & $17,47-17,55$ \\
\hline Metanoto & $7,62-8,6$ & $9,46-10,46$ \\
\hline Segmento Mediano & $1,66-2,34$ & $2,6-3,49$ \\
\hline Profêmur & $19,1-20,16$ & $19,98-20,2$ \\
\hline Mesofêmur & $15,17-16,3$ & $16,07-16,67$ \\
\hline Metafêmur & $19,28-21,9$ & $21,21-21,97$ \\
\hline Protíbia & $22,07-23$ & $21,38-22,93$ \\
\hline Mesotíbia & $16,3-18,2$ & $17,34-17,88$ \\
\hline Metatíbia & $23,21-25,76$ & $25,34-26,43$ \\
\hline Abdômen (excluindo S.M.) & $23,76-26$ & $33,57-34,38$ \\
\hline Cercos & $0,67-1,1$ & $1-1,3$ \\
\hline Placa Subgenital & $2,23-3,26$ & $9,84-9,88$ \\
\hline
\end{tabular}

Tabela 4: Intervalo de medidas de ovos de Ceroys (Ceroys) perfoliatus. As medidas correspondem aos valores médios do material analisado, em milímetros. $\mathrm{n}=5$.

\begin{tabular}{|c|c|}
\hline Dimensões & Média (em mm) \\
\hline Comprimento da Cápsula & 3,7 \\
\hline Largura da Cápsula & 2,1 \\
\hline Altura da Cápsula & 2,3 \\
\hline Altura da Placa Micropilar & 0,7 \\
\hline Largura da Placa Micropilar & 0,6 \\
\hline Altura do Opérculo & 1,2 \\
\hline Largura do Opérculo & 1,2 \\
\hline
\end{tabular}


Tabela 5: Intervalo de medidas do material de Ceroys (Ceroys) cristatus. As medidas correspondem aos valores máximos e mínimos dos espécimes analisados, em milímetros.

\begin{tabular}{|c|c|c|}
\hline & $\delta^{\lambda}(n=5)$ & $q(n=6)$ \\
\hline Corpo & $62,17-68,46$ & $47,45-71,57$ \\
\hline Antena & $63,93-72,31$ & $28,3-61,3$ \\
\hline Cabeça & $3,45-4,2$ & $4,12-5,58$ \\
\hline Pronoto & $3,17-3,87$ & $4,44-4,88$ \\
\hline Mesonoto & $15,65-18,18$ & $10,33-15,2$ \\
\hline Metanoto & $8,2-9,5$ & $5,2-7,74$ \\
\hline Segmento Mediano & $2,4-3$ & $2,44-3,44$ \\
\hline Profêmur & $22,42-22,94$ & $12,51-21,13$ \\
\hline Mesofêmur & $16,73-18,54$ & $11,43-15,13$ \\
\hline Metafêmur & $24,47-30,86$ & $14,25-20,11$ \\
\hline Protíbia & $25,9-27,64$ & $15,05-24,06$ \\
\hline Mesotíbia & $21,92-22,5$ & $12,3-17,43$ \\
\hline Metatíbia & $31,25-31,07$ & $17,33-25,37$ \\
\hline Abdômen (excluindo S.M.) & $28,69-31,35$ & $24,39-35,68$ \\
\hline Cercos & $1,6-1,72$ & $0,64-0,9$ \\
\hline Placa Subgenital & $4-4,7$ & $8,3-11,17$ \\
\hline
\end{tabular}

Tabela 6: Intervalo de medidas de ovos de Ceroys (Ceroys) cristatus. As medidas correspondem aos valores médios do material analisado, em milímetros. $\mathrm{n}=5$.

\begin{tabular}{|c|c|}
\hline Dimensões & Média (em mm) \\
\hline Comprimento da Cápsula & 3,2 \\
\hline Largura da Cápsula & 1,9 \\
\hline Altura da Cápsula & 2,05 \\
\hline Altura da Placa Micropilar & 0,6 \\
\hline Largura da Placa Micropilar & 0,6 \\
\hline Altura do Opérculo & 1,2 \\
\hline Largura do Opérculo & 1,2 \\
\hline
\end{tabular}


Tabela 7: Intervalo de medidas do material de Canuelius scaber comb. nov. As medidas correspondem aos valores máximos e mínimos dos espécimes analisados, em milímetros.

\begin{tabular}{|c|c|c|}
\hline & $\widehat{\partial}(\mathrm{n}=5)$ & $q(n=6)$ \\
\hline Corpo & $62,17-68,46$ & $47,45-71,57$ \\
\hline Antena & $63,93-72,31$ & $28,3-61,3$ \\
\hline Cabeça & $3,45-4,2$ & $4,12-5,58$ \\
\hline Pronoto & $3,17-3,87$ & $4,44-4,88$ \\
\hline Mesonoto & $15,65-18,18$ & $10,33-15,2$ \\
\hline Metanoto & $8,2-9,5$ & $5,2-7,74$ \\
\hline Segmento Mediano & $2,4-3$ & $2,44-3,44$ \\
\hline Profêmur & $22,42-22,94$ & $12,51-21,13$ \\
\hline Mesofêmur & $16,73-18,54$ & $11,43-15,13$ \\
\hline Metafêmur & $24,47-30,86$ & $14,25-20,11$ \\
\hline Protíbia & $25,9-27,64$ & $15,05-24,06$ \\
\hline Mesotíbia & $21,92-22,5$ & $12,3-17,43$ \\
\hline Metatíbia & $31,25-31,07$ & $17,33-25,37$ \\
\hline Abdômen (excluindo S.M.) & $28,69-31,35$ & $24,39-35,68$ \\
\hline Cercos & $1,6-1,72$ & $0,64-0,9$ \\
\hline Placa Subgenital & $4-4,7$ & $8,3-11,17$ \\
\hline
\end{tabular}


Tabela 8: Intervalo de medidas do material de Ceroys (Miroceroys) heymonsi. As medidas correspondem aos valores máximos e mínimos dos espécimes analisados, em milímetros.

\begin{tabular}{|c|c|c|}
\hline & $\delta^{\lambda}(n=5)$ & $q(n=6)$ \\
\hline Corpo & $45,88-50,14$ & $56,3-75,32$ \\
\hline Antena & $43,32-46,15$ & $44,53-62,7$ \\
\hline Cabeça & $2,69-3,47$ & $5-6,25$ \\
\hline Pronoto & $2,47-3,04$ & $3,55-4,16$ \\
\hline Mesonoto & $10,74-11,86$ & $11,55-16,73$ \\
\hline Metanoto & $5,9-7$ & $6,66-9,43$ \\
\hline Segmento Mediano & $1,75-2,41$ & $2,2-3$ \\
\hline Profêmur & $16,45-17,77$ & $16,68-21,46$ \\
\hline Mesofêmur & $13,45-14,8$ & $13,31-18,51$ \\
\hline Metafêmur & $17,92-18$ & $17,4-22,45$ \\
\hline Protíbia & $17,89-18,63$ & $18,53-22,37$ \\
\hline Mesotíbia & $14,06-15,13$ & $15,67-19,12$ \\
\hline Metatíbia & $19,97-22,59$ & $21,97-28,25$ \\
\hline Abdômen (excluindo S.M.) & $20,8-22,63$ & $27,55-35,6$ \\
\hline Cercos & $1,78-1,99$ & $0,93-1,35$ \\
\hline Placa Subgenital & $3,07-3,78$ & $9,51-10,68$ \\
\hline
\end{tabular}

Tabela 9: Intervalo de medidas de ovos de Ceroys (Miroceroys) heymonsi. As medidas correspondem aos valores médios do material analisado, em milímetros. $\mathrm{n}=5$.

\begin{tabular}{|c|c|}
\hline Dimensões & Média (em mm) \\
\hline Comprimento da Cápsula & 3,2 \\
\hline Largura da Cápsula & 2,05 \\
\hline Altura da Cápsula & 2,2 \\
\hline Altura da Placa Micropilar & 0,6 \\
\hline Largura da Placa Micropilar & 0,4 \\
\hline Altura do Opérculo & 1,25 \\
\hline Largura do Opérculo & 1,25 \\
\hline
\end{tabular}


Tabela 10: Intervalo de medidas do material de Ceroys (Miroceroys) saevissimus. As medidas correspondem aos valores máximos e mínimos dos espécimes analisados, em milímetros.

\begin{tabular}{|c|c|c|}
\hline & $\delta^{\lambda}(n=6)$ & $\uparrow(n=4)$ \\
\hline Corpo & $52,13-53,2$ & $60,36-64,7$ \\
\hline Antena & $56,14-68,89$ & $43,13-49,65$ \\
\hline Cabeça & $4,16-4,5$ & $6,49-6,96$ \\
\hline Pronoto & $2,65-2,91$ & $3,76-3,89$ \\
\hline Mesonoto & $11,09-11,65$ & $12,41-13,26$ \\
\hline Metanoto & $6,31-6,99$ & $5,88-7,52$ \\
\hline Segmento Mediano & $2,05-2,52$ & $2,16-3,43$ \\
\hline Profêmur & $18,3-19,9$ & $15,63-18,78$ \\
\hline Mesofêmur & $14,14-15,9$ & $12,33-14,63$ \\
\hline Metafêmur & $20,97-21,04$ & $18,42-19,92$ \\
\hline Protíbia & $21,85-22,13$ & $18,98-20,3$ \\
\hline Mesotíbia & $16,8-17,37$ & $16,38-17,7$ \\
\hline Metatíbia & $24,93-25,95$ & $23,61-24,6$ \\
\hline Abdômen (excluindo S.M.) & $23,17-23,93$ & $30,63-33,15$ \\
\hline Cercos & $1,99-2,59$ & $0,72-0,89$ \\
\hline Placa Subgenital & $3,16-4,25$ & $9,92-11,92$ \\
\hline
\end{tabular}

Tabela 11: Intervalo de medidas de ovos de Ceroys (Miroceroys) saevissimus. As medidas correspondem aos valores médios do material analisado, em milímetros. $\mathrm{n}=5$.

\begin{tabular}{|c|c|}
\hline Dimensões & Média (em mm) \\
\hline Comprimento da Cápsula & 2 \\
\hline Largura da Cápsula & 2,2 \\
\hline Altura da Cápsula & 1 \\
\hline Altura da Placa Micropilar & 0,6 \\
\hline Largura da Placa Micropilar & 1,35 \\
\hline Altura do Opérculo & 1,3 \\
\hline Largura do Opérculo & \\
\hline
\end{tabular}


Tabela 12: Intervalo de medidas do material de Ceroys (Mroceroys) sp. nov. As medidas correspondem aos valores máximos e mínimos dos espécimes analisados, em milímetros.

\begin{tabular}{|c|c|c|}
\hline & $\hat{\partial}(n=3)$ & $q(\mathrm{n}=5)$ \\
\hline Corpo & $44,4-50$ & $53.5-59.3$ \\
\hline Antena & $41-49,3$ & $35.2-46$ \\
\hline Cabeça & $2,5-3,1$ & $2,51-3,1$ \\
\hline Pronoto & $2,48-3,2$ & $3,4-4,1$ \\
\hline Mesonoto & $10,3-11,5$ & $11,8-13,1$ \\
\hline Metanoto & $6,16-7,6$ & $6,2-7,4$ \\
\hline Segmento Mediano & $1,4-1,9$ & $1,9-2,6$ \\
\hline Profêmur & $15,5-17,9$ & $15,6-17,2$ \\
\hline Mesofêmur & $11,5-14,4$ & $12,8-13,7$ \\
\hline Metafêmur & $17,6-18,5$ & $16,9-18,9$ \\
\hline Protíbia & $15,5-21,1$ & $16,3-19,7$ \\
\hline Mesotíbia & $14,4-17,4$ & $13,8-16$ \\
\hline Metatíbia & $20,1-25,5$ & $20-23$ \\
\hline Abdômen (excluindo S.M.) & $28,69-31,35$ & $26,5-29,4$ \\
\hline Cercos & $1,9-2,5$ & $0,9-1,3$ \\
\hline Placa Subgenital & $2,3-2,6$ & $7,7-8,5$ \\
\hline
\end{tabular}

Tabela 13: Intervalo de medidas de ovos de Ceroys (Miroceroys) sp. nov. As medidas correspondem aos valores médios do material analisado, em milímetros. $\mathrm{n}=5$.

\begin{tabular}{|c|c|}
\hline Dimensões & Média (em mm) \\
\hline Comprimento da Cápsula & 3,4 \\
\hline Largura da Cápsula & 2,05 \\
\hline Altura da Cápsula & 2,3 \\
\hline Altura da Placa Micropilar & 0,45 \\
\hline Largura da Placa Micropilar & 0,5 \\
\hline Altura do Opérculo & 1 \\
\hline Largura do Opérculo & 0,9 \\
\hline
\end{tabular}

